PUBLTCATIONS OF THE ARNOLD ARBORETUM, No. 9

\title{
A
}

\section{MONOGRAPH OF AZALEAS}

\section{RHODODENDRON SUBGENUS AN'THODENDRON}

\author{
BY \\ ERNEST HENRY WILSON \\ AND \\ ALFRED REHDER
}

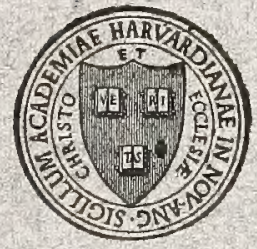

ISSUED APRIL 15, 1921

Printed from the Income of the William L. Bradiex fusd BK

THE UNIVERSITY PRESS

CAMBRIDGE 


\section{Cornell Unlversity Library}

A monograph of azaleas; rhododendron subg

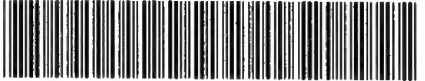

31924001197577 
A MONOGRAPH OF AZALEAS 


\section{Cornell University Library}

The original of this book is in the Cornell University Library.

There are no known copyright restrictions in the United States on the use of the text. 


\title{
A \\ MONOGRAPH OF AZALEAS \\ RHODODENDRON SUBGENUS ANTHODENDRON
}

\author{
$\mathrm{BY}$ \\ ERNEST HENRY WILSON \\ AND \\ ALFRED REHDER
}

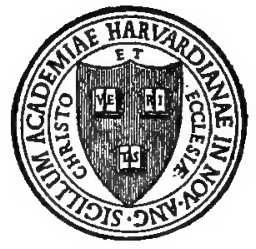

ISSUED APRIL 15, 1921

Printed from the Incone of the William L. Bradley Fund BY

THE UNIVERSITY PRESS

CAMBRIDGE 



\section{PREFACE}

THE value of Azaleas as garden plants in the eastern United States, where few of the Rhododendrons with persistent leaves can be successfully cultivated, has led to the critical studies of these plants which appear on the following pages.

Mr. Wilson's long journeys in eastern Asia has made it possible for him to study all the species of the Japanese Empire and China as wild plants, and to become familiar with the Azaleas growing in Japanese gardens. For many years the Arboretum has been engaged in a field study of the American species, and has been able to place at Mr. Rehder's disposal the large amount of material which is preserved in this herbarium, and which has been supplemented by that contained in other American collections.

The Azaleas of northern Japan and Korea, and of the northern United States, are already growing in the Arboretum, but the gardens of the southern states and of California have still much to gain by the introduction of the species of the southern states and those of southern Japan, China, and Formosa, and this publication will not have accomplished its purpose if it fails to induce the more general cultivation of these plants in the United States and Europe.

The art of the hybridizer has produced many interesting and beautiful Azaleas. Imperfect records have made the study of many of these hybrids difficult and uncertain, and this difficulty is increased by the fact that many of them are no longer cultivated unless, having escaped the change of fashion in plants, they are still growing in English gardens, planted about the middle of the last century, and I venture to suggest to my associates in the English Rhododendron Society that the study of Azaleas in European gardens might add much to the knowledge of the origin and value of many of these plants.

Arnold Arboretum

C. S. Sargent, Director.

MARCH, 1921. 



\section{TABLE OF CONTENTS}

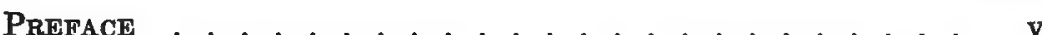

The Azaleas of the Old World. By Ernest Henry Wilson . 1

The Azaleas of North America. By Alfred Rehder . . . . 107

Doubtful Names . . . . . . . . . . . . . 197

ILLUSTRATIONS . . . . . . . . . . 203

Additrons . . . . . . . . . . . . . . . . . . . 206

INDEX . . . . . . . . . . . . . . 207 



\section{THE AZALEAS OF THE OLD WORLD}

BY

ERNEST HENRY WILSON 



\section{THE AZALEAS OF THE OLD WORLD}

\section{INTRODUCTION}

Botanists may hold different views on the classification of the subdivisions of the large genus Rhododendron, but gardeners and lovers of plants in general have no difficulty in recognizing Azaleas as distinct from other groups of the genus. It is in the popular rather than in the strictly technical sense that the title of "Azaleas of the Old World" is applied here. These plants with few exceptions are sun-loving; and their wide popularity among the peoples of the Orient, of America, of Europe and Australia is due largely to the brilliancy of their flowers, their floriferousness and the ease with which many of them can be cultivated. In the Orient they have been favorite garden flowers from very early times and in the Occident for more than a century some have been familiar and valued greenhouse plants, and in recent years it has been found that several are more hardy than they were generally supposed to be. In the Arnold Arboretum such hardy kinds as $R$. obtusum var. Kaempferi and $R$. japonicum are among the most satisfactory and most beautiful of Asiatic plants. Farther south and in California the old Azalea amoena and A. ledifolia and the newer "Hinodegiri" are much grown in gardens. Others are less known, but I believe tha"t in the near future both in increased variety and in quantity Azaleas will have a much more important place in gardens. In certain groups the hybridists in Europe have wrought wonderful results, and the field is still full of promise. In Japan, in the city of Kurume, selection and raising from seed has been in progress among a single group for a century, and these plants are now beginning to find their way into the Occident. With these facts in view the need for a critical survey of the species and forms seems necessary. Through confusion with other species and for lack of accurate names many good plants have become lost from our gardens, and others for the same reason have not been introduced. During my travels in China I greatly admired 
the red-flowered Azalea of the country so abundant on the hills from the coast to the extreme west, from near sea-level to $1300 \mathrm{~m}$. altitude. So common is it that in May much of the countryside is a blaze of red. For years I unhesitatingly accepted this plant as the Azalea indica of Linnaeus, considering the difference in the number of stamens an unimportant triviality. In 1912-13, when working up the Rhododendron material for Sargent's Plantae Wilsonianae in conjunction with my colleague, Alfred Rehder, I became conscious that all was not so simple as I had assumed. The question as to what Azalea indica really was began to arouse my interest. On the occasion of the Arnold Arboretum Expedition to Japan in 1914 I devoted much time to the problem, and in Yaku-shima in February collected an Azalea which later I discovered to be the true Azalea indica of Linnaeus. I questioned many botanists in Japan, but none at that time had any definite views on the subject. Nevertheless, by deduction and comparative study I arrived at the conclusion that the group of Azaleas cultivated in Japan under the name "Satsuki" all belonged to Linnaeus' species and that the material collected in Yaku-shima was its wild parent. On my return to the Arnold Arboretum early in 1915 I critically compared the material I had collected with Linnaeus' description and with the old figures on which his species was based, and the proof of this theory was absolute.

Japan is so rich in Azaleas, both wild on the mountains and cultivated in gardens, parks and temple grounds, that at the end of $1914 \mathrm{I}$ felt that beyond establishing the identity of Azalea indica I had acquired no more than a moderate working knowledge of the group. My interest, however, was keener than ever. Being favored with another opportunity to visit the Orient I determined to devote as much time as possible to the study of these Azaleas. During 1917 and 1918 I visited many places famous in Japan for Azaleas and gathered specimens and information from all sides. On my visits to Korea, Liukiu and Formosa I collected much new material. The result is that on my various visits to the Chinese and Japanese Empires I have seen growing wild, with few exceptions, every species known from those regions and almost every known variety and garden form. In Japan in 1914 and again in 1917-18 I received inestimable assistance from Mr. H. Suzuki, President of the 
Yokohama Nursery Company and one of the foremost horticulturists in Japan. Together we visited Mt. Kirishima and the famous Azalea district of Kurume in Kyushu, also those near Osaka and Tokyo. He introduced me to all the leading specialists, gave of his own store of knowledge freely, and without his help it would have been quite impossible to have delved so deeply into the cultivated Azaleas of Japan. It is with keen pleasure that I acknowledge my indebtedness to this genial and scholarly gentleman. I know not how many hundreds of specimens of my own collecting have been available for this work, and in addition, through the courtesy of the Director of Kew and the Keeper of the Gray Herbarium of Harvard University, I have had on loan all their material, so rich in old types of these Azaleas. In Tokyo, through the courtesy of Professor J. Matsumura, I have examined the material preserved in the Herbarium of the Imperial Botanic Garden. Dr. Merrill has kindly loaned me the material preserved in the Herbarium of the Bureau of Science, Manila. To Dr. T. Nakai I am indebted for much useful information relative to certain critical Azaleas to which S. Komatsu has recently given names with brief descriptive notes in Japanese.

The study of long-cultivated garden plants is exceedingly complex, and to fathom some of the problems is almost beyond human skill. This statement is as trite as it is true, and I freely confess that $I$ have found the problems presented by many of these Azaleas more intricate than those of the Japanese Cherries. Notwithstanding my unusual opportunities in the field and in the gardens of the Orient and the abundant herbarium material at my command I should have been ill equipped for the task but for the collection of living plants cultivated for nearly threequarters of a century on the Sargent estate in Brookline, Mass. This collection has been zealously maintained and is rich in old garden types introduced through Fortune and others, some of which have apparently been lost in Europe. Professor Sargent's knowledge of these Azaleas is profound, and it is under his sympathetic guidance and help that this little treatise has developed from chaos to order, and to him most largely is due what merit it contains. 


\section{HISTORY}

THe cultivation of plants and the development of gardens is ever a sign of a nation's advance toward culture and refinement. How early this art began in the Orient we do not know, though history tells us that plants like the Yulan and Moutan Paeony were highly esteemed garden flowers among the Chinese during the Tang Dynasty (618$907 \mathrm{~A}$. D.). It is much to be regretted that we are so ignorant of the early history of China. It is known that during the Han Dynasty (B. C. 206-A. D. 25) the Chinese had intercourse with India and Zanzibar. If proof were needed of their visiting these countries at an early period it is supplied by the presence in south China and Formosa of such typical African plants as Cactus-like Tree Euphorbias. Such species as $E$. triangularis Desf., $E$. neriifolia L. and $E$. tirucalli L. are common hedge-plants and are naturalised in certain places like Hongkong, Kowloon and elsewhere in China, and near Takao in Formosa, as they also are in parts of India. In point of fact $E$. tirucalli was named by Linnaeus from material which came from India. Did we know more about the early travels of the Chinese it is possible that we should find that they were acquainted with America long before its discovery by Columbus. In south China, Formosa and the Liukiu Islands Agave fourcroydes Lem. is naturalised, but this may have been introduced by the Portuguese, and so too may have been Maize and Tobacco. Much more difficult is it to account for Opuntia Dillenii Haw. naturalised and abundant not only on the Yunnan plateaux but in the valley of the Tung River in a remote part of extreme western China. It is significant also that Boym in his Flora Sinensis published in 1656 figures such characteristic American plants as the Pineapple (Ananas sativa Schult. f.), the Sweetsop or Custard Apple (Anona squamosa L.) and the Guava (Psidium guajava L.), which were evidently common plants in China when he was there (1642-53). In what era the love for flowers began to manifest itself in Japan is uncertain, but Buddhism in its Chinese form was introduced from Korea about 552 A. D. and from then until the 8th century Korean and Chinese monks and nuns visited Japan for purposes of proselytism. From the 8th century onward it became more usual for the Japanese 
monks to go to China in order to study the doctrines of the best accredited teachers at the fountain-head. These monks introduced into Japan a number of favorite trees and shrubs like the Ginkgo, Yulan, Moutan Paeony, Chinese Quince, the Tea-plant, Buddha's Tree (Tilia Miqueliana), Sophora japonica, Prunus tomentosa, P. japonica, Paulownia tomentosa, such fruit trees as the Peach, Apricot, Persimmon, Pear, Apple, Plum, Cherry, Loquat, the Orange and its relatives and, in all probability, the Chrysanthemum also. Though they probably did not originate the love for gardens these monks must have greatly stimulated it. The mutual love of flowers among the peoples of the Orient induced and fostered the introduction of plants from one country to another in the Far East even as it did in the Levant and, in later days, as it has in the Occident. And so we find the history of garden plants intimately associated with the social life of the peoples. We know nothing of early intercourse between the Japanese and Chinese prior to the introduction of Buddhism to Japan. We do know that Chinese monks introduced their favorite flowers to Korea, that Chinese and Korean monks carried them to Japan, and it is safe to assume that these same monks and their Japanese disciples carried to Korea and to China plants of Japan which appealed to their aesthetic sense. In fact the presence in temple-grounds and other sacred places in China of the Cryptomeria, which is endemic in Japan, and of many varieties of Japanese Camellias and Azaleas in Chinese gardens, is positive proof that Japanese plants were long ago introduced into China.

The illustrious Venetian, Marco Polo, who lived many years in China during the latter part of the 12 th century and to whom we owe the first authentic account of that mighty empire, notices from his own observation many of the vegetable productions of China used for economic purposes. After his memorable travels China was for a long time closed to European access and had been altogether forgotten in Europe when in 1516 the Portuguese first arrived in China. The Portuguese claim the honor of having first introduced the SweetOrange from China to Portugal some time between 1545 and 1548. About the end of 1542 the Portuguese adventurer, Mendez Pinto, discovered Japan, first touching at the island now known as Tanagashima south of Kagoshima in Kyushu. The Portuguese made their way north as far as Oita in northeast Kyushu where Mendez Pinto in 1543 received a friendly reception from the local Daimyo. The arquebus Pinto carried astounded the Japanese, who had never before seen any explosive weapon. In 1549 St. Francis Xavier reached Japan 
and introduced Christianity; he visited Oita, and going north to Hondo established a mission at Yamaguchi, a few miles north of Shimonoseki. This newly introduced religion soon claimed thousands of adherents, much to the alarm of the Japanese Daimyos and military men backed by Buddhist priests, and a period of persecution commenced. The native Christians migrated to Nagasaki, which soon became one of the chief marts of Portuguese trade.

In 1596 the Dutch first visited Java and other islands of the East Indies and in 1602 the Dutch East India Company was established. The war which then ensued between the Dutch, Spaniard and Portuguese for possession of the spice islands lasted until 1610 when the Dutch remained master of these seas. The seat of the Dutch government was first established on the island of Amboyna, but in 1619 it was transferred to the newly founded city of Batavia in Java. In 1600 a Dutch ship visited Japan, and nine years later the Dutch East India Company sent several vessels to Firando (Hirado), northwest of Nagasaki, where they were well received by the Japanese. In 1611 a formal edict in favor of their trade was obtained. A Dutch factory and also an English factory were established at Hirado the same year.

In 1624 Christianity was proscribed in Japan and the land was closed to foreigners. The Portuguese, English and Spaniards, who also had a factory, were expelled and only the Dutch and the Chinese were permitted to carry on trade, and that under galling restrictions. The Dutch factory was removed in 1639 to Deshima, then an islet at the head of Nagasaki harbor but now absorbed into the foreshore. And so Japan secluded herself for over two centuries from contact with the outer world until the advent of the American Expedition in 1853-54 under command of Commodore Perry. All this may seem to have little to do with plants and with Azaleas in particular and yet they are inextricably bound up with the subject. It is to the merchant adventurer that we owe all our first plant introductions from Japan and our early knowledge of the flora. From 1690-92 Engelbert Kaempfer, in the service of the Dutch East India Company, lived in Japan, and in his Amoenitates Exoticae, published in 1712, he gives an admirable account of Japanese plants. He gives good figures of many of these under the vernacular names and among them an Azalea now known as $R$. obtusum var. Kaempferi Wils. In all Kaempfer mentions twenty-one Azaleas, and it is interesting to note that many of the vernacular names he gives are in common use to-day. C. P. Thunberg in 1775 visited Japan in the capacity of physician to the Dutch Com- 
pany and in 1784 published his Flora Japonica, the first post-Linnaean work on the flora of the Orient. Thunberg mentions the Azaleas under their vernacular names and relegates them all to Azalea indica. According to Juel ( $P l$. Thunb. 391 (1918)) they represent $R$. obtusum Planch., $R$. japonicum Suring. and $R$. mucronatum G. Don.

Lastly in this connection mention must be made of Philipp von Siebold, who joined the service of the Dutch East India Company and lived at Deshima from 1823 to 1829. To him we owe the magnificent Flora Japonica; also he introduced about 1830 such ornamental plants as Lilium elegans and $L$. speciosum from Japanese gardens, and, twenty years later, several others including Malus floribunda, M. Sieboldii and certain flowering Cherries.

About 1677 the English East India Company established a factory at Amoy and in 1684, after a conflict with the Portuguese, one at Canton. Through this company many Chinese plants were introduced to India during the 18th century and early in the 19th century to England; they include several Azaleas. However, in China the Jesuit priests were the first to inform us about the flora of the land. In 1790 Joannis de Loureiro, a Portuguese, published his Flora Cochinchinensis and mentions one species of Azalea ( $A$. punctata), but this remains an obscure plant and may not belong to the genus.

During the last quarter of the 17th century Jakob Breyne, a merchant of Danzig and a distinguished botanist, visited Holland and saw growing there several famous garden plants of the Orient which he duly records in his Prodromus Plantarum. On page 24, pt. I, published in 1680, we read "Chamaerhododendron exoticum amplissimus floribus liliaceis. Frutex spectabilis elegans. In horto Beveringiano." This is the plant on which Linnaeus (Spec. 1753) bases his Azalea indica. Breyne does not say from what country this shrub had been brought, but P. Hermann, in his Academici Horti lugduno-batavi catalogus, p. 152 (1687), describes the same plant under the name of "Cistus Indicus Ledi alpini foliis, floribus amplis," figures it on page 153 , and reports that it was introduced from Jaccatra, which is Batavia, in Java. No species of Azalea grows in India, and it has been generally supposed that this Azalea had been brought to Batavia by the Chinese, but I am of the opinion that it was taken there from Japan by Dutch traders. In the gardens of Nagasaki and elsewhere, then as now, it was a common garden plant and, moreover, it is indigenous in the warm southern parts of Japan. That at the early date mentioned plants from Japan were growing in gardens in Holland is certain, 
and the Tea-plant was introduced from Japan about 1689. Breyne (Prodromus, I. 4) states that he saw in the garden of Hieronymus van Beverningk in 1678 a fine specimen of the Camphor-tree which had been introduced from Japan. Again, in his Prodromus, II. 66 (1689) Breyne tells of six varieties of Chrysanthemum from Japan which he saw growing in Holland gardens. All these early introductions seem to have been lost. I have carefully looked through many old books of the 18th century and I find no references to any species of Azaleas being in European gardens, and they appear to have been unknown in Europe at the close of the 18th century. The one oriental species was known to Linnaeus through the books. In Batavia, however, several were grown, as we know from the writings of Burmann and Blume.

In Aiton's Hortus Kewensis (1810) Azalea indica is stated to be in cultivation in Kew, having been introduced from China in 1808 by the Court of Directors of the East India Company in the ship "Cuffnels" Captain Wellbank. This plant was Rhododendron Simsii Planch., and here began a confusion between Linnaeus' species and the Chinese Azalea which still survives. Through the activities of officers of the East India Company at the close of the 18th and the beginning of the 19 th centuries English gardens were enriched by many Chinese plants. No officer was more active in this work than John Reeves, who as Chief Inspector of Tea in the Company's establishment at Canton resided in Macao and Canton from 1812 to 1831 . He was either the immediate or indirect source from which our gardens derived Camellias, Moutan Paeonies, Chrysanthemums, Roses, Wistaria sinensis and many Chinese Azaleas including $R$. Farrerae Tate, a pretty Hongkong species, and also $R$. phoeniceum G. Don, destined to be of so much value as a stock on which to graft "Indian Azaleas," so called.

In 1818 or 1819 Samuel Brooks, a nurseryman at Ball's Pond, Newington Green, sent out to China Joseph Poole, a gardener, and through him secured among other plants Azalea indica alba (R. mucronatum G. Don) and Azalea indica purpurea plena (R. mucronatum f. plenum Wils.). In 1823 Azalea sinensis ( $R$. molle G. Don) was received from China by Loddiges of Hackney and by William Wells, nurseryman, of Redleaf. In 1832 Joseph Knight, nurseryman, of Chelsea, London, secured Azalea indica variegata ( $R$. indicum $f$. variegatum DC.) and $A$. indica lateritia ( $R$. indicum Sweet) brought home from China by Mr. M'Killigan. In 1821 Rhododendron Farrerae was reintroduced and in $1832 R$. indicum var. ignescens Sweet, both through Captain Farrer of the East Indiaman "Orwell," who gave 
them to Tate, a nurseryman, of Sloane Square, London. In the Botanical Register, t. 56 (1842), is figured a double red-flowered Azalea said to be of Chinese origin and in the possession of William Wells, Esq., of Redleaf. These various Azaleas by hybridization and selection soon became the parents of a number of good plants which are figured in the periodicals of the time. Especially valuable was the Azalea indica variegata which in the hands of Knight, and of Ivery, another English nurseryman, yielded several very ornamental varieties.

In 1843 Robert Fortune was sent to China by the Horticultural Society of London, and his travels and explorations there, which ended in 1861, inaugurated a new era in the history of plant introduction from that country. He sent from Chinese gardens at Shanghai and elsewhere to England many Azaleas, including such new ones as $A z a-$ lea obtusa ( $R$. obtusum Planch.), Azalea ramentacea ( $R$. obtusum f. album Rehder), Azalea crispiflora ( $R$. indicum var. crispiflorum Schneid.), Azalea amoena ( $R$. obtusum f. amoenum Wils.), Azalea narcissiflora (R. mucronatum f. narcissiflorum Wils.), Azalea vittata (R. Simsii var. vittata Wils.) and Azalea Bealii (R. Simsii var. vittata f. Bealii Wils.). There is no need to emphasize the value of these new Azaleas. His vittata with lilac flowers and Bealii with red-striped flowers gave an impetus to the raising of new forms and may be said to have initiated an industry which has resulted in the socalled race of "Indian Azaleas." The true $R$. indicum, whose progeny are not amenable to forcing, dropped out and the forms of $R$. Simsii, $R$. mucronatum and R. obtusum - seminal, branch sports and hybridstook its place, and to these we owe the familiar greenhouse Azaleas of to-day. There is no necessity for pursuing the subject further except to point out that all the Azaleas from the Orient up to 1860 were cultivated plants introduced from gardens and that the wild parent and habitat of none except $R$. Farrerae and $R$. molle were known.

The opening of Japan, which followed the signing of treaties first with America in 1854 and then with other powers, soon led to the introduction of a great number of valuable garden plants to America and Europe. Strange to say the Azaleas for which Japan is famous seem to have been passed over for a number of years, probably on the assumption that they were the same as those already introduced to our gardens from China. From 1859-64 C. Maximowicz, the famous Russian botanist, travelled in Japan, and to him we owe our first comprehensive account of the wild flora of that country. Maximowicz and his Japanese collector, Tschonoski, were among the first to collect 
seeds of Azaleas and by this means introduced into Petrograd $R$. reticulatum $G$. Don and $R$. linearifolium var. macrosepalum Mak. Maximowicz also introduced plants of $R$. linearifolium S. \& 7., its variety macrosepalum and $\boldsymbol{R}$. scabrum G. Don. In 1861 a Hollander, J. B. Groenwegen, claims to have received direct from Japan seeds of $R$. japonicum Suring., one of the most valuable of all hardy Azaleas. Crossed with the Chinese $R$. molle G. Don this has given rise to the lovely but short-lived Kosterianum hybrids; all these, again mixed with the so-called Ghent hybrids ( $R$. luteum $\times$ American species), have produced the race of Azaleas named $\times R$. mixtum Wils.

Under each species and variety the story of its introduction is recorded, so in this historical chapter I need not repeat it. Curiously enough the most common and one of the most conspicuously beautiful Azaleas of Japan, with flame-red flowers and figured by Kaempfer, was ignored until 1892, when Professor Sargent sent seeds to the Arnold Arboretum where it has proved not only perfectly hardy but one of the most valuable exotic plants. This and $R$. japonicum, raised by Professor Sargent from seeds sent from the Jardin des Plantes in 1876, were the first oriental Azaleas to be raised from seeds in America.

Turning to Korea there is little to say, for prior to the beginning of this century the Occident had received no living plants or seeds direct from that country. A common Azalea of Korea, the lovely $R$. Schlippenbachii Maxim., found its way to Japan, and from there was sent to England by James H. Veitch in 1893. The first seeds of an Azalea sent from Korea was in 1905 when Mr. J. G. Jack sent to the Arnold Arboretum seeds of $R$. yedoense var. poukhanense Nakai, a hardy species of compact habit with rose-purple, fragrant flowers.

From the Liukiu Islands no Azaleas, either plants or seeds, have been sent direct to the Occident, but the large-flowered $R$. scabrum G. Don, better known as $R$. sublanceolatum Miq., endemic there, was long ago brought to Japan, and in Kyushu in particular it is a common garden plant. This Azalea was apparently in cultivation in England when G. Don wrote his General System in 1834, but seems to have been lost soon afterward. Maximowicz in 1864 sent it to Petrograd, but it appears to have been unknown in England when reintroduced by $\mathrm{Mr}$. Notcutt in 1911. The only Formosan Azalea introduced into Europe prior to my visit in 1918 was $R$. Oldhamii Maxim. which was raised by Messers Veitch from seeds sent in 1878 by Charles Maries. The Philippine Island species has not yet been introduced. 


\section{DISTRIBUTION}

OF the thirty-four species of Azaleas enumerated here thirty-three are widely scattered over the countries of the Orient having their northern limit in central Hokkaido, their southern on Luzon in the Philippines; from east to west they are found from the shores of the Pacific Ocean in Japan to the extreme west of China proper. They belong to four well-marked sections of the genus Rhododendron, two of which (Tsutsutsi and Scyadorhodion) are peculiar to the Orient; two (Rhodoraland Pentanthera) are represented also in America. The thirty-fourth species is $R$. luteum Sweet which belongs to the lastnamed section. It grows in the Caucasus, the Pontus region of the Black Sea and in Lithuania, Poland, and southwestern Russia, and is the only species of the groups here discussed known to grow west of China proper.

Geographically the east Asiatic species are found over 45 degrees of longitude and 30 degrees of latitude and altitudinally from sea-level to about $3300 \mathrm{~m}$. They are social plants and where climate and soil conditions are favorable, as in most parts of Japan, of Korea and of China from about the latitude of Shanghai south, these Azaleas are perhaps the most common shrubs. The Chinese R. Simsii and R. $M a$ riesii grow also in Formosa, and a variety of the first-named is endemic on the Kawanabe Islands off the northwest coast of the Liukiu Archipelago. The Japanese $R$. serpyllifolium is said to grow on Okinawa, the main island of the Liukius. At least three ( $R$. Schlippenbachii, $R$. Tschonoskii and $R$. Weyrichii) of the four Korean species grow also in Japan. One ( $R$. phoeniceum) is unknown in a wild state and is of doubtful standing. The others are endemic in the different countries of the Orient.

It is remarkable that in western China only the section Tsutsutsi with three species is represented, and on the Himalayas no member of the four sections is known to grow, yet in these two regions the subgenus Eurhododendron has its headquarters and is represented by hundreds of species. In Malaysia, too, where the subgenus Vireya is so richly represented, no species of our subgenus is known. The great concentration of species is in Japan. Formosa, considering its small 
size, is also rich in Azaleas. In China these Azaleas are poorly represented by eight species of which only three are really common and widespread. This is singular in view of the remarkable richness of the Chinese flora in general. In Korea four species grow, but at most only one ( $R$. yedoense var. poukhanense) is endemic and specimens of an Azalea much like this have been collected in Bitchu province, western Japan. In Japan Azaleas reach their northern limits in central Hokkaido, where $R$. Tschonoskii, R. Albrechtii, R. obtusum var. Kaempferi and $R$. reticulatum are found. The marked absence of limestone in Japan is favorable to the family Ericaceae which is richly represented there, and on the volcanic mountains Azaleas are astonishingly abundant. The small-flowered $R$. obtusum, the wild type of which is the form japonicum, is local, being confined to Kirishima and to a few other mountains in Kyushu, but the large-flowered variety Kaempferi grows in plenty from the extreme south, northward to central Hokkaido. The same is true of the magenta-flowered $R$. reticulatum. Billions of plants of these two species are scattered on the grass and shrub-clad slopes, in thickets, in thin woods and on the margins of forests. In May from Kyushu to central Hondo travelling by train or along the roads one is never out of sight of the blossoms of these Azaleas; in June the same is true for the north until their limit of distribution is reached. Many districts are famous for their Azaleas, and of these I may mention the slopes of Mt. Fuji, the Hakone mountains and the Nikko region. In Yamato province, and also round Fuji and Nikko $R$. japonicum with its clusters of large flame-colored flowers grows in millions. Indeed it is to her Azaleas that Japan owes much for the color which decks her countryside. And what joy it is to ramble through this flower-clad land in spring and early summer. In autumn the leaves of such species as $R$. japonicum, R. Tschonoskii, $R$. reticulatum, $R$. quinquefolium, $R$. pentaphyllum and $R$. linearifolium change to rich shades of yellow, orange, crimson and vinous purple. These autumn tints, like the wealth of brilliantly colored flowers in spring and early summer, arrest attention on every side, and small wonder that the Japanese have taken Azaleas into their gardens, parks and temple grounds and cultivated them from time immemorial. The only truly woodland species are R.quinquefolium and $R$. pentaphyllum, but so adaptable to different conditions are $R$. reticulatum and $R$. obtusum var. Kaempferi that they too may be considered woodland plants. In dark ravines, by the sides of torrents and in the forests of the Nikko region $R$. quinquefolium is plentiful, lighting up the dark and 
solemn depths with its snow-white, almost bell-shaped flowers. Crowning a knoll among mixed trees round the Hashimoto Tea House at Chuzenji and high up on the steep, wooded slope behind the Lakeside Hotel near the same place $R$. pentaphyllum is common, and I shall never forget the day in June, 1914, when I first beheld these bushes covered with masses of bright rose-pink blossoms. These two may be classed as small trees and among the Azaleas of eastern Asia are only approached in size by the pink-flowered $R$. Schlippenbachii.

$R$. Tschonoskii has the smallest flowers of any species of Azalea and, indeed, in this respect is only approached by the Chinese $R$. Seniavinii. But in size of plant the real dwarf species is $R$. serpyllifolium, which is common in the Idzu province, and is also known from Mt. Unzen near Nagasaki, and from Okinawa in the Liukiu Archipelago. Yet individual plants of $R$. obtusum f. japonicum at alpine limits of vegetation are equally dwarf.

By the sides of rock-strewn torrents high up on mountains on Yaku-shima Island $R$. indicum, the first-known of all Asiatic Azaleas, forms dense thickets more than a metre high, but in the gardens of Japan it is a dwarf and hugs the ground closely. The lovely $R$. mucronatum with its pure white, fragrant flowers has not been found wild though its pale purple-flowered variety ripense is common by the sides of certain rivers in the island of Shikoku. The pink to rose-colored $\boldsymbol{R}$. linearifolium var. macrosepalum with sticky leaves and flower-buds and an extraordinarily variable and glandular calyx is abundant in thin Pine-woods and among scrub round Futagawa, Yoshino and near Osaka. Very remarkable is the distribution of the red-flowered $\boldsymbol{R}$. Weyrichii, which is known only from parts of Shikoku in the east, from the Goto Islands in the Japan Sea, and from the island of Quelpaert off the south of Korea. The small-leafed $R$. tosaense is confined to parts of the island of Shikoku, and $R$. Schlippenbachii, which is really a Korean species, grows sparingly on Chokai-san and one or two other mountains in northern Hondo. The slender-branched $R$. $A l$ brechtii grows in thickets and on the margins of forests from the Nikko region northward to central Hokkaido, but is nowhere really common. On the foot-hills of Adzuma-yama the remarkable $R$. nipponicum, with its campanulate white corolla, shreddy, cinnamon-brown bark and fragile fruit, is common in open grass and scrub-clad country, but is not known elsewhere. On Mt. Kirishima in Kyushu $R$. obtusum f. japonicum grows under alpine conditions, but the most truly alpine species of east Asiatic Azaleas is $R$. Tschonoskii, widespread in Japan 
on high mountains from Shikoku and central Hondo north to central Hokkaido, and in Korea found on the summit of the Chiri-san. All in all the most widely spread, most variable, most spectacularly beautiful and most useful of the red-flowered Japanese Azaleas is $R$. obtusum and its variety Kaempferi.

In Korea, from Chiri-san in the extreme south of the peninsula to fifty miles north of Gensan, grows $R$. Schlippenbachii. It is partial to rocky places and thickets and often in thin woods it is the dominant undergrowth. On the famous Diamond Mountains in northeastern Korea it is particularly plentiful in mixed, rather open woods and on cliffs; in early summer its myriads of blossoms literally form sheets of pure pink for miles and miles. On exposed cliffs the habit is stiff and sturdy, but in the shade of trees the branches are slender. On Chirisan it is usually a tree-like bush, four metres tall, and it is on this mountain range that this Azalea reaches its maximum size. On bare, grass-clad and shrub-clad slopes and in Pine-woods from the latitude of Seoul southward to the island of Quelpaert $R$. yedoense var. poukhanense abounds. In full exposure it often forms low mats several yards wide, but among shrubs it is occasionally $1.5 \mathrm{~m}$. tall. This and $R$. Weyrichii are the only species that grow on Quelpaert, and the last-named is unknown on the mainland of Korea.

In China the red-flowered $R$. Simsii is wild from the coast to the extreme west, the valley of the Yangtsze River being the northern limit of its range. In many places it is extraordinarily abundant, and in May whole hillsides are red with its flowers. This species is wild in the extreme south of Formosa, and a well-marked variety (eriocarpum) is endemic on the Kawanabe Islands off northern Liukiu. This is the only Chinese species known to grow wild outside of China proper, but phylogenetically it and $R$. obtusum may be considered of common origin, and to these China and Japan owe the wealth of brilliant red color, so dominant a feature in their spring landscapes. The lovely yellow-flowered $R$. molle, better known under Sweet's name of $R$. sinense, is found on open hillsides from the coast near Ningpo to Ichang in central China. It is a social plant though local in distribution. $\boldsymbol{R}$. Mariesii grows in thickets and thin woods from Fokien to western Hupeh and also in Formosa, but its near relative $R$. Farrerae is confined to Hongkong and a few places in the neighboring province of Kwantung. On open mountains in western Yunnan the small-flowered $\boldsymbol{R}$. microphyton is abundant; this is the most alpine of the Chinese species and, with the little known $R$. atrovirens, is the most western of 
the section Tsutsutsi. The other two Chinese species are $R$. Seniavinii and $R$. Mariae, and these are apparently rare and confined to the eastcentral and south-central provinces.

In Liukiu the gaudy-flowered $R$. scabrum is endemic, but was long ago taken to the gardens of southern Japan where it is a common plant to-day. This species has the largest flowers of all Azaleas, and in a wild state and in gardens where it flowers freely is strikingly conspicuous. Unfortunately in the Occident its tendency is to flower sparingly. I strongly suspect that $R$. phoeniceum, unknown as a wild plant though introduced from Canton about 1824, and the popular stock for grafting the "Indian Azaleas" of western gardens, is specifically not really distinct from $R$. scabrum.

Although eight species grow wild in Formosa, Azaleas cannot be called a prominent feature of the vegetation. The red-flowered $R$. Oldhamii is widespread, and in districts in the north like Mt. Daiton and round Lake Candidius in the centre of the island it is fairly abundant. On grass-clad mountain slopes east of Ari-san the pretty, pink-flowered $R$. rubropilosum is plentiful. The others, so far as my personal knowledge goes, are local if not actually rare plants. Lastly, on Luzon in the Philippine Islands grows $R$. subsessile, the most southern representative of the group.

The distribution and the number of the species in the four groups are shown in the following table:-

\begin{tabular}{|c|c|c|c|c|}
\hline & Tsutsutsi & Sciadorhodion & Rhodora & Pentanthe \\
\hline Japan & 8 & 4 & 3 & 1 \\
\hline Korea & 2 & 2 & - & - \\
\hline Liukiu . & 3 & - & - & - \\
\hline Formosa & 7 & 1 & - & - \\
\hline China . & 5 & 2 & - & 1 \\
\hline Philippines . . . . . . & 1 & - & - & - \\
\hline Pontus region, Caucasus, & & & & \\
\hline $\begin{array}{l}\text { Lithuania, Poland and } \\
\text { southwestern Russia }\end{array}$ & - & - & - & 1 \\
\hline
\end{tabular}




\section{CLASSIFICATION}

MAYY of our favorite garden plants of oriental origin came to us from the gardens of China and Japan and in some instances their wild prototypes have not yet been discovered. Often when the wild plant has been discovered it has been found to differ greatly from that already in cultivation, and in consequence has to be designated as a variety or form of the described garden type. Phylogeny and taxonomy are often opposed, which is regrettable but unalterable. Students of the floras of the Orient, particularly those of China and Japan, cannot too strongly bear in mind the fact that a great many of the earliest described species are based on cultivated plants. Let me illustrate this by reference to Japan. The Japanese, like the Chinese and Koreans, are lovers of the odd and curious in flowers and trees for which they have an innate love. Nearly every house, from the poorest hovel to the castle of the feudal lord or his descendants, boasts a few flowers or a garden of some sort. The Japanese love their mountains, many of which are sacred and on most of them shrines have been raised. Pilgrimages to these mountains and shrines are a passion with the people and as mementoes of their visits it is a common practice, and has been for centuries, to bring back some strange or curious plant for their gardens. The result is that Japanese gardens are full of odd and curious plants - dwarf plants, weeping plants, fastigiate plants, plants with variegated and curiously incised foliage, plants with abnormal flowers. This love of flowers has been fostered by Buddhist priests, and this has led to mutual exchange of plants among the peoples of China, Korea, Japan and Liukiu. Now if it be properly realised that it was from such gardens - really museums of oddities that our early plants were taken and names applied to them the difficulty of identifying them with their wild parents will be better understood and appreciated.

Until after 1860 all the Azaleas introduced from the Orient were from gardens, chiefly those of Batavia, Canton and Shanghai. As the plants flowered they were given specific and varietal names, but no attempt to discover their origin was made. Some were placed under the genus Azalea and others under that of Rhododendron. Salisbury 
(Prodr. 286 (1796)) was the first to point out that Azalea and Rhododendron could not be maintained as distinct genera. In $1834 \mathrm{G}$. Don (Gen. Syst. III. 843) placed all the known species under Rhododendron. Indiscriminate naming, however continued, and in 1854 Planchon, in Flore des Serres, IX. (1854), and in Revue Horticole (1854), reviewed the varieties from the Orient, placed all under Rhododendron and multiplied considerably the specific names. In 1870 Maximowicz (Mém. Acad. Sci. St. Pétersbourg, sér. 7, XVI. No. 9 (Rhodod. As. Or.)) monographed the Rhododendrons of eastern Asia, and his work has remained the basis of all subsequent studies. Maximowicz dealt with the subject in a thorough and masterly manner. I differ from him widely in the conception and limits of certain sections and species, and in the systematic position of some varieties and forms, but I am none the less sensible of the great value of his pioneer work.

Many will regret the change of names involved but none more so than myself. These changes are as unfortunate as they are unavoidable. I adhere strictly to the rule of priority as laid down in the Vienna rules, and while this may sometimes be deemed a nuisance its fairness cannot be questioned. Moreover, if we are ever to enjoy fixed order in plant nomenclature it can only be brought about through strict adherence to accepted and established rules.

It is a pity that Planchon's name Azalea cannot be used for the subgenus. It is based on the genus Azalea of Linnaeus, the type of which is Azalea procumbens L., now known as Loiseleuria procumbens Desv. The six species enumerated under Azalea by Linnaeus (Spec. 150 (1753)) belong to two subgenera and one distinct genus, namely, Loiseleuria. With Planchon's name eliminated the oldest valid name for the subgenus is Anthodendron Endlicher."

Of the four sections of the subgenus with which we are concerned three were established by G. Don (Gen. Hist. III. (1834)) and one (Sciadorhodion) is proposed here. The section Tsutsutsi G. Don was based on the plant figured by Kaempfer (Amoen. Exot. (1712)), which is $R$. obtusum var. Kaempferi and is an excellent type of this homogeneous group. G. Don included $R$. reticulatum and $R$. Farrerae, but these have decidhous leaves, no appressed, flattened, bristle-like hairs and lack other features characteristic of Tsutsutsi proper. For this reason I refer them to a new section, Sciadorhodion. G. Don also includes $R$. molle which belongs to his section Pentanthera. Planchon

- For full details see page 115. 
in Flore des Serres, IX. (1854), emends Don's name to Tsutsia, includes under it $R$. molle and $R$. Farrerae, and adds $R$. Championae Hook. In the last-named species the flowers develop from clustered, axillary buds, and it belongs to the section Choniastrum Franchet. Maximowicz emends the section; calls it Tsutsia, but keeps under it $R$. Championae. He also emends Planchon's subgenus Azalea and employs it as a section to include $R$. Farrerae, $R$. molle and others; he also places in it $R$. macrosepalum, which obviously belongs to the section Tsutsutsi.

Of the new section Sciadorhodion, $R$. Schlippenbachii may be taken as the type, and under it we place $R$. reticulatum and $R$. Farrerae, referred by $G$. Don to his section Tsutsutsi, also $R$. Weyrichii which Maximowicz includes in his section Azalea. Together these form a very homomorphic group. The type of G. Don's section Pentanthera is the Eurasian $R$. luteum Sweet, but as most of the species are American I leave the discussion of it and also of the section Rhodora G. Don, the type of which is American though a majority of the species are Japanese, to my colleague Alfred Rehder. 


\section{KEY TO THE ASIATIC SECTIONS OF THE SUBGENUS}

\section{ANTHODENDRON ENDL.}

Flowers and leaves from the same bud.

Shoots with flattened, appressed, bristle-like hairs; leaves persistent or sometimes deciduous, usually dimorphic, scattered on the branches, elliptic to lanceolate or oblanceolate . . . . . . . . I. Tsutsutsi. Shoots glabrous or villose, without bristle-like hairs; leaves deciduous, not dimorphic, in whorls at the end of the branchlets, scattered only on vigorous shoots, usually rhombic to obovate, rarely ovate . . II. Sciadorhodion.

Flowers from the terminal bud, leaves from lateral buds below.

Corolla rotate-campanulate; stamens 8 to 10 . III. Rhodora.

Corolla funnel-form; stamens 5. . . . . . . . . . IV. Pentanthera.

\section{KEY TO THE ASIATIC SPECIES}

\section{SECT. I. TSUTSUTSI G. DON}

Bud-scales not viscid; shoots densely clothed with flattened, appressed hairs.

Corolla funnel-form-campanulate.

Stamens 5 (5 to 8 in $R$. tosaense).

Style villose at base.

Style glabrous at base.

Leaves linear-lanceolate to lanceolate or oblanceolate.

Leaves crenate-dentate; flowers red to rose-red, more than $2.5 \mathrm{~cm}$. across. . . . . . . . indicum, p. 22.

Leaves entire; flowers lilac-purple, less than $2 \mathrm{~cm}$. across

Leaves oval or obovate to lanceolate.

R. tosaense, p. 52 .

Leaves more than $1 \mathrm{~cm}$. long, the midrib beneath covered with hairs and usually with scattered hairs on the whole under surface

$R$. obtusum, p. 29.

Leaves $1 \mathrm{~cm}$. to $1 \mathrm{~cm}$. or less long, glabrous beneath, except a few

Stamens 7 to 10 . brown hairs on the midrib . . . R. serpyllifolium, p. 53.

Style villose at base.

Leaves narrow-lanceolate to oblanceolate, crenate-dentate; stamens $\mathbf{1 0}$

R. Kanehirai, p. 28.

Leaves oval to obovate or lanceolate, entire; stamens 7 to 10.

Flowers lilac to magenta; leaves generally elliptic-oblong, acute

Flowers pink.

R. subsessile, p. 51 .

Leaves conspicuously dimorphic, obovate to obovate-oblong, abruptly mucronate, 2 to $4.5 \mathrm{~cm}$. long . R. lasiostylum, p. 50 .

Leaves not conspicuously dimorphic, often widest below the middle, elliptic-ovate to ovate-oblong or elliptic to elliptic-oblong, acute. . . . . . . R. rubropilosum, p. 52. 
Style glabrous.

Flowers more than $2.5 \mathrm{~cm}$. across; leaves elliptic to elliptic-oblong or oblong-obovate, from 2 to $5 \mathrm{~cm}$. long $\quad . R$. Simsii, p. 45.

Flowers less than $2.5 \mathrm{~cm}$. across.

Leaves lanceolate, acuminate $\quad . \quad . \quad R$. atrovirens, p. 50. Leaves oval to oblanceolate, $1 \mathrm{~cm}$. or less long. $R$. Nakaharai, p. 54 .

Corolla with short, rarely long, cylindric tube and spreading lobes; stamens 5, rarely 4.

Style villose at base; flowers white to rose-color _. R. Seniavinii, p. 57.

Style glabrous.

Leaves persistent; flowers 5-partite.

Corolla rose-purple, leaves not conspicuously dimorphic, oval to lanceolate . . . . R. microphytum. p. 57.

Corolla lilac-colored, with a long tube; leaves conspicuously dimorphic, lanceolate or elliptic to oblong-obovate . . . R. Mariae, p. 58.

Leaves deciduous; flowers white, 4 to 5 partite; leaves narrow-lanceolate to ovate-lanceolate or oblong-obovate, of ten prominently 3-nerved

R. Tschonoskii, p. 55 .

Bud-scales viscid on inner surface; corolla wide funnel-form; calyx-lobes green, ample; style glabrous.

Shoots densely clothed with flattened, appressed hairs; leaves conspicuously dimorphic; stamens 10.

Leaves persistent, calyx-lobes glandular-ciliate.

Corolla scarlet to rose-red; calyx-lobes oval to lanceolate; leaves subcrenulate, coriaceous

. R. scabrum, p. 59 .

Corolla rose-purple to magenta; calyx-lobes lanceolate; leaves entire, subcoriaceous . . . . . . R. phoeniceum, p. 61.

Leaves deciduous or semipersistent, obscurely crenate-serrate, veins impressed above; corolla rose to rose-purple, fragrant, often double; calyxlobes lanceolate, not glandular. $\quad . \quad$. R. yedoense, p. 64.

Shoots with few appressed, flattened hairs and many spreading, pilose often glandular hairs.

Stamens 8 to 10; leaves persistent or semipersistent, not conspicuously dimorphic.

Corolla red, not viscid; stamens 10; ovary glandular; leaves not viscid beneath ... . R. Oldhamii, p. 66 .

Corolla white or pale-purple, viscid outside; stamens 8 to 10; ovary glandless; leaves viscid beneath . . . . . R. mucronatum, p. 68.

Stamens 5; leaves deciduous or semipersistent, lanceolate to oblanceolateovate or linear-lanceolate; corolla pink to pale rosy purple, viscid without, funnel-form or divided into linear segments; ovary glandular

R. linearifolium, p. 74.

\section{SECT. II. SCIADORHODION REHD. \& WILS.}

Leaves broadest below the middle; stamens nearly equal.

Leaves ovate; corolla pale lilac-purple; stamens 8 to 10; fruit conic-ovoid on a curved pedicel

R. Farrerce, p. 79.

Leaves ovate to ovate-lanceolate; corolla rose-color; stamens 10; fruit shortcylindric, erect

Leaves broadest about or above the middle.

Leaves rhombic; fruit cylindric.

Stamens subequal; corolla red, rotate-funnel-form; style villose

R. Weyrichii, p. 82. 
Stamens unequal, sometimes declinate; corolla rotate-campanulate.

Corolla rose-purple to magenta; style glabrous, villose or lepidote or both;

leaves with long scattered hairs when young, glabrescent at maturity; fruit cylindric, furrowed . . . . . . . R. reticulatum, p. 83.

Corolla white; style glabrous; leaves densely ciliate, short-villose, at least on midrib at maturity; fruit cylindric, terete $R$. quinquefolium, p. 87 .

Leaves broadly obovate; corolla pink; style glandular; fruit oblong-ovoid, verruculose . . . . . . R. Schlippenbachii, p. 88.

\section{SECT. III. RHODORA G. DON}

Corolla rotate-campanulate.

Leaves obovate to oblong-oblanceolate, pubescent below; flowers 3 to 6 , magenta; fruit conic-ovoid, bristly glandular . . . . R. Albrechtii, p. 91. Leaves elliptic to narrow-elliptic, glabrescent; petiole bearded; flowers 1 or 2 , bright rose-pink; fruit spindle-shape, glabrous, verrucose

R. pentaphyllum, p. 92.

Corolla campanulate, white; leaves obovate to panduriform, subsessile with scattered, bristly hairs; fruit oblong-ovoid, verruculose, with thin valves, wavy at the margin when open . . . . . . . . R. nipponicum, p. 93.

\section{SECT. IV. PENTANTHERA G. DON}

Corolla wide-funnel-form, non-glandular.

Stamens as long as the yellow corolla; leaves softly pubescent, of ten canescent; winter-buds velutinous . . . . . . . . . R. molle, p. 95.

Stamens shorter than the orange- or flame-red, rarely yellow corolla; leaves glabrous except on the veins beneath; winter-buds glabrous

Corolla tubular with spreading lobes, glandular . .

R. japonicum, p. 99. .R. luteum, p. 103 . 


\section{ENUMERATION OF THE SPECIES}

\section{SeCt. I. TSUTSUTSI G. DoN}

Rhododendron section Tsutsutsi G. Don, Gen. Syst. III. 845 (1834), excluding Nos. 30, 31, 36, 39.

Azalea Linnaeus, Spec. 150 (1753), as to species No. 1.

Tsutsutsi Adanson, Fam. Pl. II. 164 (1763).

Loiseleria Reichenbach, Fl. Germ. Exc. I. 416 (1830).

Beverinckia Salisbury ined. ex De Candolle, Prodr. VII. pt. 2, 726 (1839).

Rhododendron section Toutousi Duchartre in Orbigny, Dict. Univ. Hist. Nat. XI. 120 (1849).

Rhododendron subgenus Tsutsia Planchon in Fl. des Serr. IX. 75 (1854); in Rev. Hort. 1854, 45.

Rhododendron section Tsutsugi Miquel, Fl. Ind. Bat. II. 1059 (1857).

Rhododendron section Tsusia Maximowicz in Mém. Acad. Sci. St. Pétersbourg, sér. 7, XVI. No. 9, 32 (Rhodod. As. Or.) (1870), excluding No. 17.

Azalea subgenus Tsutsutsi K. Koch, Dendr. II. pt. 1, 171 (1872), excluding species No. 6.

Shrubs with dense twiggy branches; shoots densely or sparsely clothed with appressed, flattened, red-brown or rufous hairs, occasionally also with spreading soft hairs. Flowers from terminal bud, with leafy shoots from axils of lower scales of same bud. Leaves evergreen or half evergreen, rarely deciduous, more or less villose, rarely glandular. Corolla funnel-form, campanulate-funnel-form, rarely cylindric, with short spreading lobes; stamens 5 to 10 , equal or unequal in length, never declinate, puberulous, or pubescent; ovary strigose, sometimes glandular. Fruit conic or conic-ovoid, glabrescent or strigose-villose, 5-celled; seeds wingless.

This section is confined to eastern Asia, where it is represented by 22 species.

Rhododendron indicum Sweet, Brit. Flow. Gard. ser. 2, II. sub. t. 128 (1833). - G. Don, Gen. Syst. III. 845 (1834), excluding varieties. De Candolle, Prodr. VII. pt. 2, 726 (1839), in part. - Siebold \& Zuccar rini in Abh. Akad. Münch. IV. pt. III. 131 (Fl. Jap. Fam. Nat. 7) (1846), in part. - Miquel, Fl. Ind. Bat. II. 1059 (1857). - Maximowicz in Mém. Acad. Sci. St. Pétersbourg, sér. 7, XVI. No. 9, 37 (Rhodod. As. Or.) (1870), in part. - Franchet \& Savatier, Enum. Pl. Jap. I. 291 (1875), in part. - Schneider, Ill. Handb. Laubholzk. II. 506, figs. 331 1-m, 332 a-d (1911). - Rehder in Bailey, Stand. Cycl. Hort. V. 2944 (1916). Komatsu in Tokyo Bot. Mag. XXXII. [18] (1918).

Azalea indica Linnaeus, Spec. 150 (1753). - Burmann, Fl. Ind. 42 (1768). Willdenow, Spec. I. pt. 2, 831 (1798). - Persoon, Syn. 212 (1805). — Aiton, 
Hort. Kew. ed. 2, I. 318 (1810), as to description and synonyms. - Roemer \& Schultes, Syst. Veg. IV. 374 (1819), excluding B. - Blume, Cat. Gewass. Buitenz. 44 (1823); Bijdr. Fl. Ned. Ind. 852 (1825). - Sprengel, Syst. Veg. I. 628 (1825).

Azalea indica var. b. spatulata Blume, Bijdr. Fl. Ned. Ind. 852 (1825).

Azalea indica var. d. angustifolia Blume Bijdr. Fl. Ned. Ind. 852 (1825.)

Azalea indica var. e. floribunda Blume, Bijdr. Fl. Ned. Ind. 852 (1825).

Azalea macrantha Bunge in Mém. Soc. Etr. Sci. St. Pétersbourg, II. 115 (Enum. Pl. Chin. Bor. 41) (1833).

Azalea indica lateritia Lindley in Bot. Reg. XX. t. 1700 (1834).

Rhododendron macranthum G. Don, Gen. Syst. III. 846 (1834). 一 Sweet, Brit.

Flow. Gard. ser. 2, III. t. 261 (1834).

Rhododendron decumbens D. Don apud G. Don, Gen. Syst. III. 846 (1834).

Azalea Danielsiana Paxton, Mag. Bot. I. 129, t. (1834).

Rhododendron indicum $\delta$. P lateritium De Candolle, Prodr. VII. pt. 2, 726 (1839).

Azalea? macrantha De Candolle, Prodr. VII. pt. 2, 718 (1839).

Azalea decumbens De Candolle, Prodr. VII. pt. 2, 718 (1839).

Rhododendron Breynii Planchon in Fl. des Serr. IX. 77 (1854).

Rhododendron Danielsianum Planchon in Fl. des Serr. IX. 79 (1854).

Rhododendron lateritium Planchon in Fl. des Serr. IX. 80 (1854).

Rhododendron Sieboldii $\beta$. serrulatum Miquel in Ann. Mus. Ludg.-Bat. I. 33 (1863).

Azalea Breynii André in Belg. Hort. XV. 183 (1865).

Azalea lateritia Hort. ex André in Belg. Hort. XV. 185 (1865).

Rhododendron indicum $\gamma$. macranthum Maximowicz in Mém. Acad. Sci. St. Pélersbourg, sér. 7, XVI. No. 9, 39 (Rhodod. As. Or.) (1870). - Franchet \& Savatier, Enum. Pl. Jap. II, 292 (1875). - Makino in Tokyo Bot. Mag. XXIV. 77 (1910). - Matsumura, Ind. Pl. Jap. II. pt. 2, 461 (1912).

Rhododendron indicum $\gamma$. macranthum a. macranthum genuinum Maximowicz in Mém. Acad. Sci. St. Pétersbourg, sér. 7, XVI. No. 9, 39 (Rhodod. As. Or.) (1870). - Makino in Tokyo Bot. Mag. XXIV. 77 (1910).

Rhododendron indicum $\gamma$. macranthum b. lateritium Maximowicz in Mém. Acad. Sci. St. Pétersbourg, sér. 7, XVI. No. 9, 39 (Rhodod. As. Or.) (1870).Makino in Tokyo Bot. Mag. XXIV. 77 (1910).

Rhododendron lateritium var. brachytrichum Nakai in Tokyo Bot. Mag. XXIX [261] (1915).

Rhododendron hangnoense Nakai in Tokyo Bot. Mag. XXIX. [261] (1915).

Rhododendron indicum f. lateritium Rehder in Mitt. Deutsch. Dendr. Ges. XXIV. 225 (1916); in Bailey, Stand. Cycl. Hort. V. 2944 (1916).

Rhododendron indicum var. brachytrichum Komatsu in Tokyo Bot. Mag. XXXI. [18] (1918).

Japan: Kyushu, prov. Osumi, Yaku-shima, side of torrents, alt. 300-800 m. February 19, 1914, E. H. Wilson (No. 6003); same place, without collector's name (Herb. Bur. Sci. Manila); prov. Hizen, Nagasaki, 1873, Capt. Blomfield (Herb. Kew); same locality, ex Herb. Lugd.Bat. 1863, as R. Sieboldii var. minor, in part (Herb. Kew and Herb. Gray); same locality, cultivated, 1863, C. Maximovicz (Herb. Kew, co-type of $R$. indicum $\gamma$. macranthum b. lateritum Maximowicz). Hondo, prov. Shinano, 1864, Tschonoski (Herb. Kew); prov. Sagami, Hakone, cultivated, June 21, 1914, E. H. Wilson (No. 6888); near Uraga, 1862, 
C. Maximowicz (Herb. Kew and Herb. Gray, co-type of $R$. indicum $\boldsymbol{\gamma}$. macranthum subvar. a. genuinum Maximowicz); prov. Suruga, foot of Mt. Fuji, cultivated, June 13, 1914, E. H. Wilson (No. 6932); prov. Musashi, Yokohama, cultivated, 1862, C. Maximowicz (Herb. Kew and Herb. Gray); Tokyo, cultivated, July 2, 1882, K. Miyabe; same locality (Herb. Bot. Gard. Tokyo, type of $R$. lateritium var. brachytrichum Nakai); prov. Shimotsuke, Nikko, alt. 600-1000 m. cultivated and sub-spontaneous, June 20 flowers, October 20 fruit, 1914, E. H. Wilson (Nos. 6816, 6818, 7709).

Cultivated: Java ex Herb. Ludg.-Bat. 1863, as R. indicum Sweet (Herb. Kew); Hongkong Bot. Gard. May 12, 14, 31, 1919, W. J. Tutcher.

The only place where I have seen this species truly wild is Yaku-shima, an island some ninety miles south of Kagoshima and interesting as being the southern limit of the range of a great many Japanese plants. On that island $R$. indicum Sweet is a common fluviatile shrub growing from a half to two meters high and forming dense masses in open country on the banks of rock-strewn streams. Elsewhere in Japan I found it cultivated only, although in old burial and temple grounds it is often more or less naturalized. Makino says it grows spontaneously in the provinces of $\mathrm{Kii}$ and Yamato in Hondo and not so very far from the old capital of Kyoto. In an old burial ground at Nikko the plants were prostrate or nearly so and with their scattered, large red flowers strongly suggested the Rock Cistus, and one saw how very applicable was the name the ancients gave this plant. The plants though often decumbent are naturally upright and very densely branched; the branches are slender but rigid and are clothed with flattened, appressed, strigose, chestnutbrown hairs which in the second and third years lose their color and disappear. The leaves are sub-coriaceous and crowded, short-petioled, narrow-lanceolate, lanceolate to oblanceolate, mucronulate, dark green, rather shining above, pallid or sub-glaucous beneath, ciliolate, usually remotely crenate-dentate, with scattered, closely appressed, red-brown setose hairs on both surfaces; in the autumn the leaves change to crimson and vinous purple. The flowers are terminal, solitary or in pairs; the corolla is broad-funnel shape, opening at the same time or immediately before annual growth commences, bright red to scarlet, sometimes rosered; there are 5 stamens shorter than the style but equalling or exceeding the
corolla in length.

In Japanese gardens this Azalea is a prime favorite and I was told that something like two hundred named forms are recognized. It is planted on or among rocks, singly or in groups, and is used as a garden edging. It bears trimming well, and its naturally low, dense habit makes it particularly useful in the gardens of Japan. Its native name is "Satsuki-tsutsuji," that is Fifth-month Azalea, from the fact that it blossoms in June, which is the fifth month of the year reckoning by the old
Chinese calendar.

The first mention of this plant in a European book is in Breyne's Prodromus, I. 23 (1680), which I have not seen, but in the edition of 1739 it is mentioned in pt. I. 16 as "Chamaerhododendron exoticum, amplissimis floribus liliaceis." Breyne was a merchant of Danzig and a distinguished botanist who visited Holland during the last quarter of the 17 th century and in his Prodomus described the ro markable plants he saw there. His "Chamaerhododendron" was growing in the garden of a Mr. Beveringk, but no mention is made of its country of origin. 
Hermann in his Academici Horti lugduno-batavi catalogus 152. fig. (1687), describes and figures it under the name of "Cistus Indicus, Ledi Alpini foliis \& floribus amplis." He cites Breyne and says the plant came from Jaccatra (that is Batavia, Java). Hermann's figure though crude is easily recognized as representing the plant we are discussing and can in fact be identified with no other species. Doubtless it was taken by Dutch trading ships from Nagasaki to Batavia and from there to Holland. Ray in his Historia Plantarum II. 1895 (1688) mentions it, citing Hermann and Breyne. On this plant of Breyne, Hermann and Ray, Linnaeus (Spec. 150 (1753)) bases his Azalea indica so there can be no mistake as to its identity even though Linnaeus gives the habitat as the East Indies, and cites "Tsutsusi Kaempfer Amoen. 845, t. 846," which is Rhododendron obtusum var. Kaempferi Wils. The plant of Breyne and Linnaeus is Kaempfer's "Token, vulgo Satsuki, Cytisus Liliifer autumnalis Tsutsusi congener," of which he mentions (Amoen. Exot. fasc. V. 849 (1712)) five kinds, including single and doubleflowered red and white forms.

Linnaeus' species was introduced into England in 1833 by Mr. M'Killigan to Knight's Nurse in Chelsea under the name of Azalea indica lateritia and flowered there for the first time in May 1834. About the same time forms differing slightly in color were brought from China to England by officers commanding the East India Company's trading ships and named Azalea Danielsiana; $R$. macranthum and $R$. decumbens. According to Hovey (Mag. Hort. V. 25 (1839)) Azalea lateritia and A. Danielsiana were introduced from England into Boston, Mass., in 1838. Up to about 1845 color forms, many of seedling origin, of $R$. indicum were more numerous in our gardens than those of $R$. Simsii and these with forms of $R$. phoeniceum and $R$. mucronatum (Azalea ledifolia) collectively constitute the Azalea indica of the period. It is recorded that on March 13, 1837, ten varieties of Azalea indica were exhibited at Ghent by Mr. Charles Deloose and awarded a gold medal. After 1850 the true Rhododendron indicum and its forms rapidly dropped from cultivation and the name was appropriated for the varieties of the Chinese $R$. Simsii Planch. Aiton in 1810 and Sims in 1812 were first to unite the Japanese and Chinese plants; Sweet in 1832 made the Chinese plant a variety of $R$. indicum. The rest of the story is told by the synonomy, but that the confusion is complete is proved by the fact that to-day Linnaeus' plant is absolutely unknown to gardens under the name he gave it. In fact it has become more or less lost to cultivation, although its double-flowered form, balsaminaeflorum, is well known and appreciated. $R$. indicum is really a very pretty species and well adapted for rockeries in mild, moist countries, and is about as hardy as $R$. obtusum $\mathrm{f}$, amoenum Wils. I sent seeds and plants of it from Japan to the Arnold Arboretum in 1914. The Azalea "J. T. Lovett" of American gardens, claimed to be of hybrid origin is nothing but the true $R$. indicum. Up to about 1850 several varieties of this Azalea were cultivated under the name of "Indian Azaleas" and in all probability hybrids between it and $R$. Simsii Planch. were obtained. Such old varieties as "The Bride" with white flowers, and Van Houtte's Azalea indica punctulata, A. punctulata variegata, $A$. punctulata omnicolor (Fl. des Serr. XVI. 17, tt. 16181623 [1865]) are, I think, hybrids between the two species. In the evolution of the large-flowered "Indian Azalea" of commerce of to-day I doubt if $R$. indicum has had any part. The fact that it cannot be forced by strong heat to blossom out of season is against it, since this is a marked feature of the "Indian Azaleas" of greenhouses to-day. When grafted on the vigorous $R$. phoeniceum the size of the flowers is increased.

A form with white flowers is: -

Rhododendron indicum f. hakatashiro Millais, Rhodod. 193 (1917). 
Rhododendron indicum f. Hakatajiro Komatsu in Tokyo Bot. Mag. XXXII. [45] (1918).

This is often seen in old Japanese gardens and has been introduced into England.

A form with salmon-red flowers whitish at the base is: -

Rhododendron indicum f. tanimanoyuki Millais, Rhodod.193 (1917). Komatsu in Tokyo Bot. Mag. XXII. [45] (1918).

The best known to-day of all the forms of $R$. indicum is: -

Rhododendron indicum var. balsaminaeflorum Nicholson in Kew Hand-list, pt. 2, 53 (1896); ed. 2, 499 (1902). - Bean, Trees and Shrubs Brit. Isl. II. 362 (1914). - Millais, Rhodod. 193 (1917).

Azalea Rollissoni T. Moore in Florist and Pomol. 1878, 35 fig.-Garden XVIII. 254, t. 249 (1880).

Azalea rosaeflora R. Dean in Fl. Mag. XIX. t. 418 (1880).

Azalea balsaminaeflora Carrière in Rev. Hort. 1882, 432 t. - Nicholson, Dict. Gard. I. 149, fig. 196 (1887).

Azalea indica var. rosiflora Rehder in Bailey, Cycl. Am. Hort. I. 122, fig. 176 (1900).

Rhododendron indicum var. rosiflorum Rehder in Bailey, Stand. Cycl. Hort. V. 2944 (1916); in Mitt. Deutsch. Dendr. Ges. XXIV. 226 (1916).

Rhododendron indicum Rollisoni Millais, Rhodod. 193 (1917).

This interesting little plant is common in the gardens of Japan, and it is there, as in the West, of very slow growth. It is uncertain whether it was first introduced into England or France. In the Garden, XVIII. p. 254 (1880), it is said to have been "introduced about three years ago by Messrs. Rollisson." Carrière says it was introduced into France from Japan by M. Viésener in 1877. On Long Island, New York, it is hardy in sheltered, shady places. Bean says "it has lived outof-doors for many years at Kew but prefers a milder climate," Millais states that it is "a great favorite for rock gardens, where it does not always flourish." The Japanese name for the Azalea is "Komanyo-satsuki."

Similar but rather less double is:-

Rhododendron indicum f. kinnozai Millais, Rhodod. 1913 (1917).

An old form is: -

Rhododendron indicum f. variegatum De Candolle, Prodr. VII. pt. 2, 726 (1839).

Azalea. indica var. a. variegata Blume, Bijdr. Fl. Ned. Ind. 852 (1825).Lindley in Bot. Reg. XX. t. 1716 (1834). - Hovey, Mag. Hort. V. 25 (1839).

Rhododendron indicum f. Matsushima Millais, Rhodod. 193 (1917).

This has white and red striped and spotted flowers and blooms irregularly the year round. In the nursery district round Osaka it is known as "Shiki-takanesatsuki." In Blume's time it was cultivated in Java, and according to Lindley it was introduced into England by Mr. M'Killigan in 1833, to Knight's nursery in Chelsea, London. From this Azalea Knight raised several seedling forms which received names. Such plants as Azalea indica exquisita Lemaire (in $\mathrm{Fl}$. des Serr. III. t. 239 (1847), syn. $R$. indicum equisitum Lemaire) and Azalea indica Iveryana albo- 
cincta Van Houtte (in Fl. des Serr. XI. 211, t. 1180 (1856)), are probably seedlinge from Azalea indica variegata. So too are Azaleas "Gledstanesii," "Iveryana," "Charles Encke" and "Reine Louise." In fact this var. variegatum was the parent of most of the best "Indian Azaleas" cultivated up to about 1850. According to Hovey the var. variegatum was introduced into Boston, Mass., in 1838, and for many years was a familiar and much admired plant at exhibitions. It is still cultivated in the Holm Lea collection, so also are the above mentioned named forms. These Azaleas were famous in their day and have been grown in this country for more than seventy years. "Gledstanesii" was raised by Messers Rollis son of Tooting and exhibited for the first time in London on May 15, 1841. It was imported into this country by Hovey \& Co., Boston, Mass., who exhibited it before the Massachusetts Horticultural Society on May 2, 1846. In England the var. variegatum appears to have been lost to cultivation until quite recently, when it was reintroduced under the name used by Millais.

A curious and abnormal form is:-

Rhododendron indicum f. polypetalum Wilson, n. comb.

Rhododendron indicum $\gamma$. macranthum c. polypetalum Maximowicz in $M \mathrm{em}$. Acad. Sci. St. Pétersbourg, sér. 7, XVI. No. 9, 40 (Rhodod. As. Or.) (1870).

Cultivated: Hongkong Bot. Gard. May 20, 1919, W. J. Tutcher.

I have seen the Herb. Kew co-type of this curious plant with its petaloid, deeply laciniate calyx and no corolla. In Japan its vernacular name is " Kin-no-zai." I have not seen this plant nor the following, which has a proper calyx and a deeply laciniate corolla.

\section{Rhododendron indicum f. laciniatum Wilson, n. comb.}

Rhododendron indicum $\gamma$. macranthum subvar. b. lateritium f. laciniatum Makino in Tokyo Bot. Mag. XXVII. 110 (1910).

Makino gives "Shide-satsuki" as the Japanese name of this curious form. Komatsu enumerates several other forms, but the only other it is necessary to mention here is the very distinct: -

Rhododendron indicum var. crispiflorum Schneider, Ill. Handb. Laubholzk. II. 506 (1911). - Rehder in Bailey, Stand. Cycl. Hort. V. 2944 (1916).

Azalea crispiflora Hooker in Bot. Mag. LXXIX. t. 4726 (1853). - Lemaire, Jard. Fl. IV. t. 430 (1854). - Hovey, Mag. Hort. XXIII. 70 (1857); XXIV. 141 (1858).

Azalea indica crispiflora Van Houtte in Fl. des Serr. IX. t. ad p. 79 (1854).

Rhododendron crispiflorum Planchon in Fl. des Serr. IX. 83 (1854); in Rev. Hort. 1854, 67.

This interesting variety has thicker leaves than the type and the wavy margins of its corolla give it a distinct appearance. The Azalea indica var. grandiflora Blume, of which there is a specimen in Herb. Kew collected by Thomas Lobb, is similar, but the margin of the corolla is not wavy. $R$. indicum var. crispiflorum, was introduced into England from China by Robert Fortune to the nursery of Messers Standish \& Noble in 1850 or 1851 . It was imported from England to Boston, Mass., in 1855 by C. M. Hovey; soon afterwards a plant was acquired by Ignatius Sargent, Esq., father of Professor C. S. Sargent, and descendants of the 
original plant are in the Holm Lea collection to this day. In England it appears to have been lost to cultivation until plants were sent to Kew and elsewhere from Holm Lea by Professor Sargent.

\section{Rhododendron Kanehirai Wilson, n. sp.}

Frutex ramosissimus, 1-2.5 m. altus; rami graciles, ramulosi, juveniles pilis compressis castaneis adpressis vestiti. Folia petiolata, dimorpha; vernalia sparsa, lineari-lanceolata vel oblongo-lanceolata, 2-5 cm. longa, $0.5-1.5 \mathrm{~cm}$. lata, acuta, glanduloso-mucronulata, basi attenuata, obscure crenato-serrata, supra atroviridia, subtus pallida, utrinque pilis lucide brunneis strigosis adpressis vestita, venis supra impressis; folia aestivalia in apice ramulorum aggregata, linearioblanceolata vel anguste obovata, $1.5-3 \mathrm{~cm}$. longa, $0.2-0.6 \mathrm{~cm}$. lata, apice acuta vel rotundata, ceterum ut vernalia; petioli 1-5 mm. longi, dense pilis compressis castaneis adpressis vestiti. Flores terminales, bini vel raro solitarii, carminei vel scarlatini; pedicelli robusti, erecti, 5-8 mm. longi, dense pilis castaneis strigosis vestiti; calyx plerumque bene evolutus; lobi virides, erecti, rotundati vel ovales, 1-5 mm. longi, 1-2 mm. lati, pilis adpressis lucide castaneis ciliati; corolla anguste infundibuliformis, $2.5-4 \mathrm{~cm}$. longa et $2-2.5 \mathrm{~cm}$. lata, glabra; stamina 10 , ineaqualia, corolla breviora, flamentis gracilibus infra medium papillose pubescentibus, antheris 1-1.5 mm. longis; ovarium dense pilis cinereis vel castaneis strigosis obtectum; stylus gracilis, $3-4 \mathrm{~cm}$. Iongus, ad basin pilis paucis compressis strigosis instructus, stigmate parvo capitato. Fructus non visus.

Formosa: prov. Taihoku, Urai, in a garden at the police station, April 1, 1918, E. H. Wilson (No. 10,276).

This new species is closely related to $R$. indicum Sweet, which is distinguished chiefly by its smaller leaves, rather larger, usually solitary flowers, its 5 stamens with anthers from 2 to $3 \mathrm{~mm}$. long and by its stouter and glabrous style. The chief morphological difference is the number of stamens, and it may eventually prove that this new species is a decandrous variety of the old Linnean plant. I saw it in the garden mentioned above and was told that the plants had been brought from the higher slopes of the surrounding mountains. It is distinct from anything else I have seen and apparently has nothing to do with any of the species described by Hayata. The flowers vary in color from carmine-red to scarlet.

Rhododendron breviperulatum Hayata, Icon. Pl. Formos. III. 129 (1913). - Kanehira, Formos. Trees, 318, fig. 16 (1917). - Komatsu in Tokyo Bot. Mag. XXXII. [14] (1918).

Formosa: prov. Nanto, Horisha, planted in Hotel garden, December 6, 1918, E. H. Wilson (No. 11,206).

This red-flowered Azalea is well characterized by its 5 stamens and its pilose style; also by its leaves, which are oblong to oblanceolate or more rarely oblongovate, with no conspicuous difference between those of the spring and summer. The calyx-lobes are membranous, reddish, from 3 to $4 \mathrm{~mm}$. long, ciliate and pilose without, glabrous within. The corolla is from 2.5 to $3 \mathrm{~cm}$. long and broad; the stamens are nearly as long as the corolla and have rather large purple anthers. The young shoots and leaves are clothed with red-brown to gray appressed hairs. The plants my specimens came from were from 1 to $1.5 \mathrm{~cm}$. tall and had rather slender branches. I was told that they had been brought from the neighboring mountains. 
I cannot be absolutely sure of the correct identification of this plant. It agrees very well with Hayata's description, though the calyx and corolla are larger than he describes them, and the apiculate base of the anthers is by no means very apparent.

Rhododendron obtusum Planchon in Fl. des Serr. IX. 80 (1854); in Rev. Hort. 1854, 64. - Schneider, Ill. Handb. Laubholzk. II. 506, fig. 332e (1911). - Rehder in Bailey, Stand. Cycl. Hort. V. 2944 (1916). Jour. Jap. Bot. I. [173] fig. (1917), - Komatsu in Tokyo Bot. Mag. XXXII. [39] 1918. - Miyazawa in Tokyo Bot. Mag. XXXII. [318] (1918).

Azalea indica Thunberg, Fl. Jap. 84 (1784), in part, not Linnaeus. - Juel, Pl. Thunb. 391 (1918).

Azalea obtusa Lindley in Jour. Hort. Soc. Lond. I. 152 (1846); in Bot. Reg. XXXII. t. 37 (1846).

Rhododendron Thunbergii Planchon in Fl. des Serr. IX. 78 (1854).

Rhododendron Sieboldii minor Miquel in Ann. Mus. Ludg.-Bat. I. 33 (1863); II. 164 (1865-66); Prol. Fl. Jap. 96 (1866-67).

Azalea Thunbergii André in Belg. Hort. XV. 184 (1865).

Rhododendron indicum $\delta$. obtusum Maximowicz in Mém. Acad. Sci. St. Pétersbourg, sér. 7, XVI. No. 9, 40 (Rhodod. As. Or.) (1870). - Franchet \& Savatier, Enum. Pl. Jap. I. 292 (1875), - Matsumura, Ind. Pl. Jap. II. pt. 2, 461 (1912). - Bean, Trees and Shrubs Brit. Isles, II. 362 (1914). - Millais, Rhodod. 193 (1917).

Azalea indica var. obtusa Rehder in Bailey, Cycl. Am. Hort. I. 122 (1900).

Rhododendron indicum Kirishima Millais, Rhodod. 193 (1917).

Rhododendron obtusum f. a. Honkirishima Komatsu in Tokyo Bot. Mag. XXXII. [39] (1918).

Japan: Kyushu, prov. Osumi, Kirishima-jinza in a garden, said to have come from Nishi-Kirishima, May 5, 1918, E. H.Wilson (No.10,328); prov. Hizen, Nagasaki, G. H. Langsdorff (Herb. Kew); same locality, cultivated, 1863, C. Maximourcz (Herb. Kew, Herb. Gray); probably same locality, von Siebold (Herb. Kew, Herb. Gray); Hondo, prov. Kii, May 3, 1886, H. Mayr; prov. Musashi, Tokyo, cultivated, May 11, 1883 (Herb. Kew); same locality, May 12, 1904, K. Sakurai; cultivated, Imperial Botanic Garden, Tokyo, March 29, 1914, E. H. Wilson (No. 6338); Yokohama, cultivated, Yokohama Nursery Company's grounds, April 30, 1918, E. H. Wilson; Tokyo, Hilgendorf, ex Mus. Bot. Berol. (Herb. Bur. Sci. Manila); prov. Rikuzen, Sendai, cultivated, May 26, 1888, U. Faurie (No. 2296, Herb. Kew); prov. Ugo, Akita, cultivated, May 20, 1888, U. Faurie (No. 2132, Herb. Kew); Japan, without locality, L. Savatier (Herb. Kew); without locality or collector's name, ex Herb. Lugd.-Bat. (Herb. Kew, Herb. Gray as $R$. Sieboldii var. minor Miquel). 
It is always unfortunate when a selected or garden form has to do duty as the type of a species. Such is the case here and the result is that the phylogenetic order is inverted. Under the name of "Kirishima-tsutsuji" this plant has for centuries been grown in Japanese gardens. By this name it is mentioned by Kaempfer (Amoen. Exot. fasc. V. 849 [1712]), and his description is perfectly accurate. It is a densely branched, twiggy plant, seldom more than a metre high and usually less, and has small, scarlet, slightly scented flowers. Like all its relatives it is exceedingly floriferous, and in April and early May, as Kaempfer says, the whole plant appears blood red. In the autumn the leaves are lustrous and assume fine crimson tints. The typical form has rather pointed corolla-lobes, as shown in Lindley's figure, and this is the one so abundantly grown around Tokyo and Yokohama. At Kurume in Kyushu this typical form is called "Hiryu." In the nursery district round Osaka a form with rounded corolla-lobes is grown and sold as the Kirishima Azalea, and it is this form that is grown in many western gardens as the real $R$. obtusum Planch. At Kurume what appears to be this form is called "Hino-tsukasa." A hose-in-hose form of the type is grown around Tokyo as "Yayegiri" and at Kurume as "Yayehiryu." In addition a number of other slight forms are grown, some of which are mentioned by Komatsu.

Like a number of other Japanese Azaleas this plant was first sent to western gardens from China. Robert Fortune found it in the Pou-shan Azalea gardens near Shanghai, and sent it to the Horticultural Society of London in 1844. Fortune saw in the same Chinese garden the hose-in-hose (semi-double) form. Fortune's introduction was named and figured by Lindley. The figure shows the obovate, rounded, obtuse, mucronate summer leaves of the previous year and two newly developed elliptic-lanceolate, acute spring leaves. Too little attention has been paid to the fact that the red-flowered species of this section of Rhododendron all have dimorphic leaves. Those which are formed immediately after the flowere open are from lanceolate to ovate or elliptic in shape, acute, light green in color and membraneous in texture. The "spring leaves" are followed by "summer leaves," which are smaller, more or less obovate in shape, obtuse or rounded at the apex, dark green and fairly coriaceous. These spring leaves are normally deciduous and the summer leaves persistent, but climate exercises a strong influence, - the colder it is the more deciduous the leaves, and vice versa. In the early summer when the larger spring leaves predominate, the plant presents a very different appearance to what it does in late autumn or early spring when the small obovate summer leaves only are present. The overlooking or inappreciation of this simple fact has resulted in much confusion in the classification of the species and forms.

Now as to the origin of $R$. obtusum. Its name "Kirishima Azalea" would appear to suggest its original habitat. Working on this clue I visited Mt. Kirishima and am convinced that the so-called "Kirishima Azalea" is simply a color form of the Azalea so extraordinarily abundant on this mountain and hereunder referred to as f. japonicum. Long ago some pilgrim to this sacred mountain took back a plant or plants as a souvenir, planted it in his garden and from it (or them) has sprung all the plants of this particular Azales in gardens to-day. The Japanese have always been fond of making pilgrimages to their sacred shrines and mountains, and their houses and gardens are often museums filled with souvenirs of such visits. The Azalea known as amoena is unquestionably of like origin, and so too is "Hinodegiri," a more recent comer but an established favorite in our gardens. Further, the race of Azaleas known as "Kurume Azaleas," with which we are only just now becoming acquainted, is a garden product derived by long cultivation from the same common stock - the vari-colored Azalea of Mt. Kirishima, f. japonicum Wils. 
A form with white flowers is: -

Rhododendron obtusum f. album Schneider, Ill. Handb. Laubholzk. II. 506 (1911). - Rehder in Bailey, Stand. Cycl. Hort. V. 2944 (1916).

Azalea ramentacea Lindley in Jour. Hort. Soc. Lond. IV. 291, fig. (1849).

Rhododendron ramentaceum Planchon in Fl. des Serr. IX. 81 (1854); in Rev. Hort. 1854, 65.

Azalea obtusa alba Mottet, Dict. Hort. Jard. I. 302 (1892-93).

Rhododendron (Azalea) Indicum obtusum album, Garden and Forest, 1X. 394, fig. 52 (1896). - Bean, Trees and Shrubs Brit. Isl. II. 362 (1914).Millais, Rhodod. 193 (1917).

Azalea indica var. obtusa f. alba Rehder in Bailey, Cycl. Am. Hort. I. 122 (1900).

Azalea amoena alba Möller's Deutsch. Gärtn. Zeit. XVIII. 476, fig. (1903).

Cultivated : Hort. Holm Lea, Brookline, Mass.; Hort. Berckmans, Augusta, Georgia, March 18, 1909, April 6, 1914, C. S. Sargent.

This is another of Fortune's introductions from China to the garden of the Horticultural Society of London. It was received in May, 1846, from Hongkong, and certainly from a garden (although this is not expressly stated) and doubtless of Japanese origin. It has the dense, twiggy habit characteristic of its class, pure white flowers with a normal calyx and rather large leaves. In every essential respect it agrees with f. japonicum Wils., of which it is nothing but a selected, cultivated form, as are A. obtusa, A. amoena, "Hinodegiri" and the "Kurume Azaleas." Among the latter are several white-flowered forms with relatively large leaves. Under f. japonicum the origin of this "obtusum" group of Azaleas is discussed, but I may add here that variants of $f$. japonicum having white flowers have been found wild on Nishi-Kirishima. Such a plant is growing in a garden at the foot of the mountain and from it I gathered specimens. I have been unable to find out just when this plant was introduced into America but in all probability it was very soon after its appearance in England. For more than sixty years it has. been cultivated in the Holm Lea collection and from there was sent by Professor Sargent to England, where it appears that it had become lost, and to the Berckmans and to other gardens.

A form with a small corolla and long exserted stamens is: -

Rhododendron obtusum f. macrostemon Wilson, n. comb.

Rhododendron macrostemon Maximowicz in Mém. Acad. Sci. St. Pétersbourg, sér. 7, XVI. No. 9, 41, t. 3, figs. 15-20 (Rhodod. As. Or.) (1870). - Franchet. \& Savatier, Enum. Pl. Jap. I. 292 (1875). - Ōkubo in Tokyo Bot. Mag. IX. 40 (1895). - Schneider, Ill. Handb. Laubholzk. II. 507, fig. $332 \mathrm{~h}-\mathrm{k}$ (1911). - Millais, Rhodod. 205 (1917).

Rhododendron indicum var. macrostemon Ökubo \& Makino in Tokyo Bot. Mag. XVI. 178 (1902). - Matsumura, Ind. Pl. Jap. II. pt. 2, 461 (1912).

Rhododendron Kaempferi var. macrostemon Makino in Jour. Jap. Bot. I. 18 (1917). - Komatsu in Tokyo Bot. Mag. XXXII. [43] (1918).

Japan: Hondo, prov. Musashi, Tokyo, cultivated, 1862, C. Maximowicz (Herb. Kew, co-type).

This garden plant is characterised by its small flowers, minute calyx, and long exserted stamens, which are three times as long as the corolla. It is, however, 
more a condition of than a distinct form. In all the forms of $R$. obtusum, including the large flowered var. Kaempferi, the stamens are variable in length, and are inconstant in this from year to year. In the wild f. japonicum and the cultivated "Kurume Azaleas" the stamens are conspicuously variable in length. The same is true of the $f$. multicolor. Besides the co-type cited above there is another Japanese specimen in the Kew Herbarium from Maximowicz, collected by Tschonoski in Shinano province, central Hondo, in 1864, and labelled, apparently in Maximowicz's handwriting, "Rhod. indicum a. Kaempferi forma subalpina." This differs only in having larger flowers than those of his $R$. macrostemon.

\section{A well-known form with magenta-colored flowers is:-}

Rhododendron obtusum $\mathrm{f}$. amoenum Wilson, n. comb.

Azalea amoena Lindley in Paxton, Flow. Gard. III. 81, t. 89 (1852). - Hooker in Bot. Mag. LXXIX. t. 4728 (1853). - Rev. Hort. 1854, 241, t. - Van Houtte in Fl. des Serr. IX. 75, t. 885 (1854). - Hovey, Mag. Hort. XXII. 9 (1856); XXIII. 70 (1857); XXIV. 141 (1858).

Rhododendron amoenum Planchon in Fl. des Serr. IX. 80 (1854); in Rev. Hort. 1854, 64. - Bean, Trees and Shrubs Brit. Isl. II. 341 (1914).

Rhododendron Buergeri Miquel in Ann. Mus. Lugd.-Bat. I. 34 (1863); in II. 164 (1865-66); Prol. Fl. Jap. 96 (1866-67).

Rhododendron indicum e. amoenum d. genuinum Maximowicz in Mém. Acad. Sci. St. Pétersbourg, sér. 7, XVI. No. 9, 41 (Rhodod. As. Or.) (1870). Franchet and Savatier, Enum. Pl. Jap. I. 292 (1875). - Matsumura, Ind. Pl. Jap. II. pt. 2, 461 (1912). - Millais, Rhodod. 193 (1917).

Rhododendron indicum $\epsilon$. amoenum b. normale Maximowicz in Mem. Acad. Sci. St. Pétersbourg, sér. 7, XVI. No. 9, 41 (Rhodod. As. Or.) (1870).

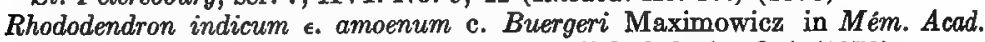
Sci. St. Pétersbourg, sér. 7, XVI. No. 9, 41 (Rhodod. As. Or.) (1870).

Azalea amoena Caldwelli Caldwell apud Van Geert, Icon. Azal. Ind. 45, t. 17 (1882).

Azalea indica var. amoena Rehder in Bailey, Cycl. Am. Hort. I. 122 (1900). Rhododendron Kaempferi var. amoenum Rehder in Sargent, Trees and Shrubs, II. 30 (1907). - Schneider, Ill. Handb. Laubholzk. II. 505, fig. 332, f-g (1911).

Rhododendron obtusum var. amoenum Rehder in Bailey, Stand. Cycl. Hort. V. 2944 (1916). - Komatsu in Tokyo Bot. Mag. XXXII. 41 (1918).

Azalea amoena Hatsu-giri Millais, Rhodod. 113 (1917).

Japan: Kyushu, prov. Hizen, cultivated, Nagasaki, 1863, $C$. Maximowicz (Herb. Kew, Herb. Gray). Hokkaido, prov. Oshima, Hakodate, cultivated, 1861, C. Maximowicz (Herb. Kew as f. normale Maxim.). Without locality, probably Nagasaki, ex Herb. Lugd.Bat. (Herb. Kew as R. Buergeri Miquel).

Cultivated: Hort. Standish (Herb. Kew, type of Bot. Mag. t. 4728). Arnold Arboretum, May 29, 1884, May 24, 1902 (Nos. 862-1, 862-2).

This Azalea, with its small, rich magenta-colored flowers, its small leaves and dense, twiggy habit, is too well known to need further description. It was frist sent to England in 1850 or 1851 from Shanghai by Robert Fortune and was soon recognized as the most hardy of its class. It is generally assumed to be of Chinese 
origin, but there is no evidence to support this view. On the contrary, I do not think there can be any doubt whatever that it is a Japanese plant and merely a color form of the Azalea so abundant on Nishi-Kirishima, Kyushu, hereunder described as f. japonicum. Moreover it is simply one of a race of charming Azaleas which for more than one hundred years have been grown and developed in the city of Kurume in the southern island of Kyushu, Japan, and is now becoming known as "Kurume Azaleas." The typical form of amoenum has hose-in-hoseflowers and is known at Kurume under the name of "Kochonomai"; it is considered the hardiest of all. The single-flowered form, the f. normale of Maximowicz, is known and more especially around Tokyo, as "Hatsu-giri." The peculiarity of the calyx becoming petaloid and forming a hose-in-hose flower is common to the whole race of "Kurume Azaleas" and is found in every one of the white and colored forms, and by selection and vegetative propagation it becomes fixed.

The typical amoenum with hose-in-hose flowers was introduced into America by C. M. Hovey, Boston, Mass., in $\mathbf{1 8 5 5}$ and soon established itself as a favorite exhibition plant. There are numerous named forms of this Azalea, and in $\mathbf{1 8 7 9}$ Pynaert (Rev. Hort. Belg. V. 277), figures Azalea amoena "Mrs. Carmichael " and mentions five others that were in commerce. In recent years, at least, amoenum has been used in hybridizing with forms of $R$. Simsii and the result is a beautiful race of small-flowered, hose-in-hose Azaleas of which the well-known "Hexe" ("Firefly" of American gardens) is a familiar example. Near Boston amoenum is not entirely hardy but on Long Island and southward it is perfectly so.

The wild form of the species is: -

Rhododendron obtusum f. japonicum Wilson, n. comb.

Rhododendron indicum є. amoenum a. japonicum Maximowicz in Mém. Acad. Sci. St. Pétersbourg, sér. 7, XVI. No. 9, 41 (Rhodod. As. Or.) (1870).

Rhododendron Kaempferi var. japonicum Rehder in Sargent, Trees and Shrubs, II. 30 (1907). - Schneider, Ill. Handb. Laubholzk. II. 505 (1911).

Rhododendron indicum var. japonicum Makino in Tokyo Bot. Mag. XXII. 56 (1908).

Rhododendron kiusianum Makino in Tokyo Bot. Mag. XXVII. 174 (1914); in Jour. Jap. Bot. I [173] fig. (1917). - Komatsu in Icon. Pl. Koisikav. II. 95, t. 132 (1915); in Tokyo Bot. Mag. XXXII [18] (1918).

Rhododendron amoenum var. japonicum Bean, Trees and Shrubs Brit. Isl. II. 341 (1914). - Millais, Rhodod. 113 (1917).

Rhododendron obtusum Miyazawa in Tokyo Bot. Mag. XXII. [318] (1918), not Planchon.

Japan: Kyushu, prov. Hizen, Wunzen (Mt. Onsen) near Nagasaki, 1863, C. Maximowicz (Herb. Kew, Herb. Gray); prov. Osumi, Kirishima-jinza, in a garden, October 1, 1918, E. H. Wilson (No. 10,957); Nishi-Kirishima, alt. 600-1600 m., May 5, 1918, $E$. $H$. Wilson (Nos. 10,329, 10,333); same locality, alt. 1300 m., March 10, 1914, E. H. Wilson (No. 6255); same locality, November 1, 1918, E. H. Wilson (Nos. 11,248, 11,250, 11,255 seeds only); same locality, June 1, 1916, S. Kawagoe; same locality, May 18, 1917,Z. Tashiro; same mountain, Makizono, May 4, 1918, B. Miyazawa; Kirishima-jinza, cultivated, plant said to have come from Mt. Kirishima, May 5, 1918, 
E. H. Wilson (Nos. 10,327, flowers white). Hondo, prov. Settsu, cultivated round Osaka, May, 1918, E. H. Wilson (form "Hinodegiri"); prov. Musashi, cultivated, Hatagaya, Hort. Oishi, May, 1914, E. H. Wilson (80 named forms of "Kurume Azaleas").

Cultivated: Hort. J. S. Ames, 1920 (10 forms of "Kurume Azaleas"); Hort. Kew, May 17, 1909; Hort. Holm Lea, March, 1920 (50 forms "Kurume Azaleas").

This is the phylogenetic type of the race of amall flowered Azaleas so plentiful in Japan and of which amoena, obtusa, and "Hinodegiri" are perhaps the best known in western gardens. It is especially abundant on the wind-swept slopes of Nishi-Kirishima, an active volcano in south Kyushu. It is found above the tree-level, growing among lava and in volcanic ashes with coarse grasses and miscellaneous low shrubs. At its lowest altitudinal range the leaves are persistent, but higher up they are deciduous. The plants are seldom a metre tall, more usually less than half of this, and quite commonly they are prostrate or hug boulders closely. The habit is normally dense and twiggy, but when sheltered a few strong shoots develop and the plant becomes relatively tall and sparsely branched. The leaves vary greatly in size according to altitude and exposure and are smallest on the plants which annually shed their foliage. On an average plant the spring leaves are oval to elliptic-ovate, from 1 to $2 \mathrm{~cm}$. long and from 0.5 to $1 \mathrm{~cm}$. wide, but they may be smaller or larger. The upper surface is bright green and the under usually pallid. The summer leaves are darker, more coriaceous and from oblanceolate to obovate in shape, with the mucronate apex rounded or acute. Normally the leaves are tufted at the ends of the twigs, but on free-growing shoots they are scattered; both shoots and leaves are clad with appressed, pale gray to yellowish, straight hairs. The flowers vary a little in size, in degree of fragrance, and greatly in color; the most common shades are rosy mauve to magenta, but salmon and salmon-red are plentiful; pink, scarlet and crimson are rather rare. Plants bearing white flowers are occasionally found. It is very floriferous; each twig terminates in a flower-bud, often in a cluster of from three to five, and from each one to three flowers develop in the spring. The bud-scales are dry, nowhere glandular, and are ciliated with pale gray hairs. The calyx is usually well developed with green, oval to nearly orbicular, ciliate lobes; sometimes it is quite small. The corolla lobes may be rounded or pointed and the stamens may be shorter or longer than the corolla; the anthers vary in color from pale yellow-brown to deep magenta, this being correlated with the color of the flowers. The capsule is variable in size and the calyx-lobes are persistent.

From the above facts is it apparent that this plant is responsive to varying ecological conditions and that its extreme forms present a very different appearance. This is indeed true, nevertheless this form is well marked and, except that there is no definite demarkation between it and the variety Kaempferi, presents no difficulty unless an attempt be made to subdivide it. This I find impossible to do, and fortunately it is not necessary, since all the color forms have received names in gardens and may be classed under the general title of "Kurume Azaleas," from a town in Kyushu where much attention has been paid to their cultivation and development.

The type of this form came from Mt. Onsen, a volcano not far from Nagasaki, but I do not know whether it is plentiful there. It also grows on other Kyushu mountains. On Kirishima it is abundant and when in flower forms sheets of color on the bare or grass-clad, bleak slopes and is strikingly attractive. Mt. Kirishima, of 
which there are two principal peaks, Nishi and Higashi, is a sacred mountain celebrated in Japanese mythology. It was on Nishi-Kirishima that the god Ninigi, grandson of the sun-goddess Amaterasu, alighted when he came down from heaven to pave the way for the conquest of Japan. A bronze aword, fixed in the ground, hilt upward, crowns the peak and is considered to be a relic of this divinity. To a place so sacred pilgrimages have been made by the Japanese from time immemorial. With their profound love for flowers some of the pilgrims would certainly take back as a souvenir living plants of this charming Azalea. Naturally it was named for the mountain, and in the course of time was distributed widely in the gardens of Japan. It is easily understood that a plant bearing flowers of an unusual color would be that selected as a souvenir by the average pilgrim. It is such forms that reached gardens first, and so we find the red obtusa the magenta amoena, the white $a l b a$ to be the earliest known. In the autumn of 1918 I collected a quantity of seeds on Nishi-Kirishima for the Arnold Arboretum. These have been widely distributed, and it will be interesting to watch the range of variation in the habit foliage and flowers of resultant plants. I fear, however, that they will not prove so hardy as the var. Kaempferi, but that they will find a welcome in gardens I am quite sure.

On visiting Nishi-Kirishima, where between 650 and $1500 \mathrm{~m}$. altitude this form japonicum grows in great abundance, and after seeing the wide range of color among the flowers, I am absolutely convinced that this Azalea is the wild parent of the race known as "Kurume Azaleas." The plant ( $R$. obtusum Planch.) which, following International Rules, has to do duty as type of this species, also belongs to this race, and of it too there is a hose-in-hose form known as "Yayehiryu" in Kurume. Another of these Azaleas which in recent years has become widely known is the brilliant red-flowered "Hinodegiri." Curiously this form so abundant in Tokyo and Osaka gardens is to-day not grown at Kurume. But good as the forms named above are, they are surpassed by many hardly known in western gardens, and in fact scarcely known in Japan outside of Kurume and a narrow circle of enthusiasts. Millais in his Rhododendrons makes the first reference to the race in a European publication. I first became acquainted with "Kurume Azaleas" in 1914, when at the invitation of Mr. H. Suzuki of the Yokohama Nursery Company" and a foremost Japanese horticulturist, I accompanied him on a visit to the nursery district at Hatagaya, a few miles north of Tokyo. There, in the garden of Mr. Oishi, I saw thousands of tiny plants bearing white and colored flowers of nearly every hue. I secured a set of fragments and dried them for our herbarium, and later, in 1916, at my suggestion Mr. John S. Ames, North Easton, Mass., purchased a selection of living plants from Mr. Oishi's collection. These arrived in the spring of 1917 and were the first " Kurume Azaleas" introduced into eastern North America. In May, 1917, I saw in the Yokohama Nursery a few large plants of "Kurume Azaleas," trained into umbrella-shape, in full flower and this decided me to visit the place of their origin. This became possible in the spring of 1918 and I was fortunate to have as a companion my friend Mr. H. Suzuki. Kurume is some 800 miles south by west from Tokyo and is quite an important city, but the fame of its Azaleas is likely to make it better known in the near future. The Azaleas are grown in a number of gardens and nurseries, but the oldest and best collection is that of Mr. Kijiro Akashi. This fine old gardener has for more than forty years devoted himself to the development of this race of Azaleas and has raised from seeds and perpetuated by cuttings nearly all the forms in cultivation. Mr. Akashi gave me the history of the race, and it seems that it originated about one hundred years ago with a gentleman named Motozo Sakamoto, who lived at Kurume. The parents came from sacred Mt. Kirishima, but whether brought from there by Sakamoto himself or given to him by some pilgrim is uncertain. At any rate, 
Sakamoto cultivated several kinds and raised and selected seedlings, including one he named "Azuma-kagami," from which it is claimed all the pink-flowered forms have descended. After the death of Mr. Sakamoto his collection passed into the possession of Akashi with the result above stated. The original plant of "Azumakagami " is still healthy, and I tried but without success to induce Mr. Akashi to part with it. Japanese experts recognize by name more than 250 kinds of Kurume Azaleas, but the differences are often infinitesimal. I made a selection of fifty kinds in duplicate which the following year (1919) safely reached the Arnold Arboretum. The two leading experts, Messers Akashi and Kuwano, at my suggestion selected the following six as the pick of them all:- "Takasago" (pale pink, hose-in-hose), "Azuma Kagami" (deep pink, hose-in-hose), "Kirin" (deep rose shading to silvery rose, hose-in-hose), "Kumo No Uye" (pure salmon), "Kurai No Himo" (carmine, hose-in-hose), "Kureno Yuki" (white, hose-in-hose). My companion and I concurred, but had the number been twenty the task would have been much easier.

To my mind the "Kurume Azaleas" are the loveliest of all Azaleas. The colors are so pure and exquisite and of every hue and shade from white, pink and salmon to scarlet, crimson and the richest magenta. Many of them are delicately fragrant. The hose-in-hose forms have none of the ugly features of double flowers, but on the contrary they are singularly attractive and the flowers last longer. The stamens, always five, are straight, exserted or included and the anthers vary in color from pale yellow-brown to blackish crimson; the color of the corolla and that of the anthers being correlated. The plants are often trained as low standards with a compact umbrella-shaped crown; less commonly they are dense and globose, or open and irregular in form. They are extremely floriferous, and in season the blossoms often completely hide the leaves. The leaves are of course dimorphic, but apart from this they vary considerably in size, in their shades of green, in their autumn-coloring and in their degree of persistence. In a great measure these variations are correlated with the color of the flowers, and experts in Japan can with ease distinguish each variety by its foliage and general appearance. It is strange that a race so rich in forms and of such decorative value should have remained unknown to us until now. Yet the explanation is simple. Interior Kyushu is little known to the western world, and even to those Japanese whose home is on the other islands. The feudal system of government which until comparatively recently obtained in Japan created and preserved this aloofness. Further, Kurume is remote from the horticultural centres of Osaka and Yokohama, from whence we have drawn the bulk of our garden plants and where a business is made of growing for export. Nagasaki is much nearer, but in the days of Thunberg and Siebold, Veitch, Maximowicz and Fortune intercommunication was difficult, and for foreigners impossible. And so it has resulted that the product of Sakamoto's hobby richly developed by Akashi has remained hidden from the outside world until now. During the last decade the fame of the Kurume Azaleas has reached Osaka, Tokyo and other places, and growers have obtained stocks and are propagating them apace. Unfortunately every grower and enthusiast names the plants according to his fancy and the result in a few years will be chaos. And this is helped by the fact that every slight sport or variant is kept and named and no attempt at selection made. I do not see how it is possible to improve upon the strain grown in Kurume unless yellow could be injected. What is needed is rigorous selection and the reduction of the named forms to fifty or less. In the past seedling selection and preservation of sports by vegetative propagation have been the sole means employed in the evolution of the race of "Kurume Azaleas," but now attempts at hybridising them with the large flowered "Indian" and "ledifolia" types are in progress. This may result in a new race, but whether it will be as lovely and 
fascinating as the present one is doubtful. In the matter of their origin Mr. Akashi was careful to inform me that for purposes of policy he had not before set forth the facts so clearly and that more or less distorted versions had appeared in print in Japan. To test the story for ourselves Mr. Suzuki and I on leaving Kurume visited and ascended Nishi-Kirishima and were convinced.

In the garden of Mr. Akashi I selected and obtained a double set of the undermentioned fifty varieties of these Azaleas which I consider the best, and these safely reached the Arnold Arboretum on April 24, 1919. The names are those of the originator, Akashi, and therefore authentic. The plants will be propagated and distributed under these names and, owing to the reprehensible habit of changing names by Japanese nurserymen, will probably remain the only set with standard names in existence.

No. 1. Seitrai

2. KURENo YUKI . .

3. Shin SeikaI

4. YorozuYo

5. Nani Wagata .

6. TANCHO

7. Hachika Tsugi

8. Irohayama . . .

9. Hoō . . .

10. SutyōHI .

11. Takasago .

12. Kasumi Gaseki

13. Bijinsui

14. Asagasumi

15. Kimigayo .

16. Azuma Kagami.

17. Osaraku

18. Otome .

19. AYA KaMMURI .

20. Shintoki No Hagasane

21. SAOTOME

22. KrRIN

23. Tamafuyo.

24. Kiritsubo.

25. OMOINE ..

26. Onnō Mezame .

27. Katsura No HaNa

28. Sthin Utena.

29. Kuмo No Uye

30. BentFUde .

31. Suga No Ito

32. Kasane KagaribI

33. Tsuta Momiji . . .

34. Suetsumu .

35. FUdestte Yama .

36. Ima Sthōjō . . . . . .

37. Rashö MoN

38. WAKA KAYEDE .

39. YAYEHIRYU flowers white, hose-in-hose

flowers white, hose-in-hose

flowers creamy white, hose-in-hose

flowers white

flowers white, suffused with salmon-pink

flowers flesh-color, hose-in-hose

flowers white, suffused with lavender

flowers white, margined with pale lavender

flowers white, tinged with pink

flowers flesh-color

flowers pale pink, the color of apple-blossoms

flowers pale pink

flowers pale pink

flowers rose-pink, hose-in-hose

flowers pink

flowers deep pink, hose-in-hose

flowers white, suffused and margined with lavender

flowers blush pink

flowers rose-color

flowers rose, shading to pink, hose-in-hose

flowers rose-color

flowers deep rose, shading to silvery rose

flowers white, striped peach-color

flowers rosy mauve

flowers pale lavender

flowers deep rose-color

flowers rose-color

flowers pale salmon

flowers pure salmon

flowers salmon

flowers pure pink

flowers dull salmon-red

flowers bright red

flowers crimson

flowers light red

flowers bright red, hose-in-hose

flowers scarlet

flowers red

flowers bright scarlet, hose-in-hose 
40. Kurai No Himo

41. Agemaki .

42. HINODEGIRI .

43. AroI

44. Sakdra Tsukasa.

45. Tama No Utena.

46. Gosho ZaKuRA

47. UKaMUSE

48. Hinode No Taka

49. Osarakt Seeding .

50. Hana Asobi. flowers carmine, hose-in-hose

flowers carmine

flowers bright crimson

flowers color of almond-blossoms, hose-inhose

flowers rosy mauve

flowers pale salmon

flowers white, striped peach-color

flowers vermilion, hose-in-hose

flowers crimson

flowers white, suffused and margined with lavender

flowers red

Rhododendron obtusum var. Kaempferi Wilson, n. comb.

Azalea indica Thunberg, Fl. Jap. 84 (1784), in part, not Linnaeus.

Rhododendron Kaempferi Planchon in Fl. des Serr. IX. 77 (1854); in Rev. Hort. 1854. - Rehder in Sargent, Trees and Shrubs, II. 29, t. 113 (1907), flowers here represented with more than 5 stamens; in Bailey, Stand. Cycl. Hort. V. 2944, fig. 3393 (1916). - Schneider, Ill. Handb. Laubholak. II. 505, fig. $331 \mathrm{~g}-\mathbf{k}$ (1911). - Bean, Trees and Shrubs Brit. Isl. II. 363 (1914). - Millais, Rhodod. 197, fig. (1917). - Komatsu in Tokyo Bot. Mag. XXXII. [16] (1918).

Rhododendron Sieboldii Miquel in Ann. Mus. Ingd.-Bat. I. 33 (1863), excluding varieties; in II. 164 (1865-66); Prol. Fl. Jap. 96 (1866-67).

Azalea Kaempferi André in Belg. Hort. XV. 184 (1865).

Rhododendron indicum a. Kaempferi Maximowicz in Mém. Acad. Sci. St. Pétersbourg, sér. 7, XVI. No. 9, 38 (Rhodod. As. Or.) (1870). - Franchet \& Savatier, Enum. Pl. Jap. I. 291 (1875).-Matsumura, Pl. Nikko, 71 (1894); Ind. Pl. Jap. II. pt. 2, 460 (1912). - Shirasawa, Icon. Ess. For. Jap. II. t. 61, figs. 1-10 (1908).

Azalea Indica var. Kaempferi Rehder in Bailey, Cycl. Am. Hort. I. 122 (1900); in Möller's Deutsch. Gärtn.-Zeit. XVII. 417, figs. (1902).

Rhododendron scabrum var. Kaempferi Nakai in Tokyo Bot. Mag. XXXIII. 208 (1919).

Rhododendron scabrum var. Kaempferi f. 2. latifolium Nakai in Tokyo Bol. Mag. XXXIII. 209 (1919).

Rhododendron scabrum var. Kaempferi f. 3. tubiflorum Nakai in Tokyo Bot. Mag. XXXIII. 209 (1919). Komatsu in Icon. Koisikav. IV. 7, t. 216 (1918).

Rhododendron scabrum var. Kaempferi f. 4. angustifolium Nakai in Tokyo Bot. Mag. XXXIII. 209 (1919). Komatsu in Icon. Koisikav. IV. 31, t. 228 (1918).

Japan: Kyushu, prov. Osumi, Yaku-shima February 25, 1914, E. H. Wilson (No. 6082); Mt. Kirishima, western slopes, alt. 10001500 m., March 8, 1914, E. H. Wilson (No. 6228); lower slopes of NishiKirishima, alt. $600 \mathrm{~m}$., May 5, 1918, E. H. Wilson (No. 10,334); foothills round base of Nishi-Kirishima, sea-level to alt. $500 \mathrm{~m}$., May 4, 1917, E. H. Wilson (Nos. 10,326, 10,330, 10,334); same general locality, April 29, 1917, Z. Tashiro; prov. Satsuma, Kagoshima, March 15, 1917, E. H. Wilson; same locality, May 6, 1918, E. H. 
Wilson (No. 10,343); Togo, March 14, 1914, E. H. Wilson (No. 6278); prov. Hizen, Nagasaki, 1862, R. Oldham (Nos. 505, 507, 508, 607, Herb. Kew, Herb. Gray); same locality, A. C. Maingay (Nos. 872, 882, Herb. Kew); prov. Buzen, Kokura, April 20, 1903, U. Faurie. Shikoku, prov. Tosa, Osaki, June 5, 1889, K. Watanabe (Herb. Gray). Hondo, prov. Yamaguchi, near Onoda, June 17, 1918, E. H. Wilson (Nos. 10,379, 10,380, 10,381); between Habu and Asa, May 7, 1918, E. H. Wilson (No. 10,368A); round Ajisa, May 17, 1917, E. H. Wilson (No. 8424); prov. Yamato, Yoshino, April 22, 1914, E. H. Wilson (No. 6575); prov. Shinano, above Narai, alt. 1100 m., September 3, 1905, J. G. Jack; without precise locality, 1864, Tschonoski (Herb. Kew); Togakushi-yama, July 9, 1884 (Herb. Kew); prov. Idzu, Oshima, March 30, 1917, July, 1918, E. H. Wilson (No. 8200); prov. Sagami, Hakone, May 12, 1918, E. H. Wilson (No. 10,365); Miyanoshita, August 24, 1892, C. S. Sargent; Kamakura, May 2, 1914, E. H. Wilson (No. 6610); prov. Musashi, Yokosuka, May, 1875, H. N. Moseley (Herb. Kew); Yokohama, 1862, C. Maximowicz (Herb. Kew); Mt. Takao, H. Takeda (No. 89, Herb. Kew); Mt. Mitake, May 19, 1907, K. Sakurai; prov. Shimotsuke, between Nikko and Lake Chuzenji, September 3, 1892, C. S. Sargent; in a garden at Umagaeshi, near Nikko, alt. $1000 \mathrm{~m}$., June 4, 1914, E. H. Wilson (No. 6807); shores of Lake Chuzenji, November 3, 1892, C. S. Sargent; Nikko region, alt. 100-1500 m., May 16, 1914, E. H. Wilson (No. 6679); prov. Ugo, Akita, May 17, 1888, U. Faurie (No. 2128 Herb. Kew); Lake Towada, June 25, 1894, U. Faurie (No. 13,272); prov. Mutsu, Shichi-nobe, June 15, 1886, U. Faurie (No. 661); prov. unknown, Mt. Nagi, Mimasaka, May 8, 1903, S. Arimoto (Herb. Gray); without locality, 1866-74, L. Savatier (Herb. Kew, Herb. Bur. Sei. Manila). Hokkaido, prov. Oshima, Hakodate, C. Wright (Herb. Kew, Herb. Gray); same locality, July, 1859, C. Wilford (No. 1017, Herb. Kew); same locality, 1861, M. Albrecht (Herb. Kew, Herb. Gray); same locality, July 29, 1888, T. Tokubuchi; prov. Iburi, Nobori-betsu, June 15, 1893, U. Faurie (No. 10,020, Herb. Kew); Chitose, June 12, 1889, T. Tokubuchi; prov. Hidaka, T. Tokubuchi; Samani-sando, June 19, 1884, K. Miyabe (Herb. Gray); prov. Ishikari, Sapporo, July 29, 1888, May 8, 1895, T. Tokubuchi; same locality, October, 1891, K. Miyabe; same locality, May 24, 1903, S. Arimoto (Herb. Gray); ex Agricultural College, Sapporo, June 7, 1885.

Cultivated: Arnold Arboretum (Nos. 3690, 3690-1, 3690-3, $3690-5,3697)$. 
This is the Mountajn or Hill Azalea (Yama-tsutsuji) of Japan, where it is abundant from Yaku-shima in the extreme south to central Hokkaido in the north. Its altitudinal range is from sea-level to about $1600 \mathrm{~m}$, though north of the Nikko region it is much less. In May and June by the wayside and on the hills and mountain-slopes it is most conspicuous with its wealth of brilliant red flowers. It grows among grasses and in thickets, also on the edge of forests and among the undergrowth in thin woods, but it is a sun-loving plant and is seen to best advantage in open thickets on mountain-slopes. The height is from 1 to $3 \mathrm{~m}$., but averages from 1 to $1.5 \mathrm{~m}$., and according to situation it may be densely or laxly branched and form either a broad or a narrow, twiggy bush. In the warmer parts of Japan all the summer leaves and often some of the large spring leaves are persistent, but in the colder parts they are both deciduous. The spring leaves vary in shape from lanceolate or lanceolate-ovate to elliptic, and in size from 1.5 to $6 \mathrm{~cm}$. in length and from 0.8 to $3 \mathrm{~cm}$. in width, and they may be either acute or obtuse; the summer leaves are elliptic to obovate in shape, as is usual in the group to which this plant belongs. The pubescence on the shoot, leaf, calyx, ovary and fruit varies in color from pale gray to rufous. Typically the color of the flowers is red, usually bright red, but it varies considerably and, excluding the forms to be mentioned later, may be any shade from flesh-color to bright red. In size the flowers vary somewhat but average from 2.5 to $4 \mathrm{~cm}$. across. The corolla-lobes are rounded or pointed. The calyx is normally well-developed and the lobes are green, ciliate and usually rounded, and from suborbicular to elliptic or ovate in shape, and from 2 to $8 \mathrm{~mm}$. long; usually they are from 2 to $4 \mathrm{~mm}$. long and occasionally they are scarcely noticeable. The stamens may be included or exserted and this considerably affects the appearance of the flowers; the anthers vary in color from pale yellow-brown to blackish purple. The fruit is woody, erect, ovoid and from 0.6 to $1.5 \mathrm{~cm}$. high, and when open the valves are recurved for about one-third their length.

In its typical form this variety, with its relatively large clustered flowers each with five stamens, cannot be confused with anything else, but there are intermediate forms which inextricably link it with $R$. obtusum. The extremes look widely different, yet on analysis size alone remains, and in this there is every gradation both among the leaves and flowers. The degree of persistence of the leaves, which is dependent upon winter temperature and exposure, strongly affects the appearance of the plants. The leaves, flowers, genital organs and fruit vary in size, and the flowers, anthers and pubescence vary in color. Round the base of Nishi-Kirishima the typical red-flowered var. Kaempferi is plentiful; on the middle and upper slopes of the mountain the typical $\mathrm{f}$. japonicum abounds. In my ascent of this mountain and after exhausting every means I could think of I failed completely to discover where one variety ended and the other began. The transition was both gradual and complete. At my request my colleague, Alfred Rehder, has critically examined the mass of material in our possession and is in complete agreement as to the specific identity here set forth. I confess that I should much prefer to keep Kaempfer's Azalea as a species distinct from $R$. obtusum, but the facts as I interpret them will not permit of this. Whether var. Kaempferi or the f. japonicum is best entitled to be considered the phylogenetic type of the species is difficult to determine, but the first named is much more widely distributed, and north of Hamamatsu, in prov. Totomi, central Hondo, is the only representative of the species.

Kaempfer's Azalea was first introduced to the Occident by Professor Sargent, who sent seeds of it from the Nikko region and elsewhere in Japan to the Arnold Arboretum in the autumn of 1892, where plants flowered in May, 1897. It has proved both hardy and amenable to cultivation here, and in late May and early June of each year flowers abundantly, producing most vivid and spectacular floral 
displays. The flowers last longer and are seen to best advantage when growing in the partial shade of conifers and other evergreen plants. In full sun the flowers bleach and fade more quickly. In the Arnold Arboretum the leaves are quite deciduous. This Azalea is the only kind with red flowers hardy in this Arboretum and is one of the most valuable exotic flowering plants ever brought into cultivation in eastern North America.

\section{A form with white flowers is: -}

\section{Rhododendron obtusum var. Kaempferi f. albiflorum Wilson, n. name.}

Rhododendron Kaempferi f. album Nakai in Tokyo Bot. Mag. XXIX. [261] (1915).

Unknown to me and described in Japanese only. Presumably normal except for its white flowers but possibly the same as the f. monstrosum Wilson.

A form with vari-colored flowers is: -

Rhododendron obtusum var. Kaempferi f. multicolor Wilson, n. f. Japan: Hondo, prov. Yamaguchi, round Ajisu, May 17, 1917, E. H. Wilson (No. 8420 type, 8421, 8422, 8423, 8419, 8418, 9417, 8416); same locality, September 28, 1918, E. H. Witson (No. 10,959 seeds only); between Habu and Asa, May 7, 1918, E. H. Wilson (No. 10,368); prov. Mikawa, round Futagawa, May 9, 1918, E. H. Wilson (No. 10,347).

This form differs from Kaempfer's Azalea in its vari-colored flowers which range from pale pink, salmon or mauve to purple and magenta. Some of the shades are exquisite and scarcely two companion bushes have flowers of identical color. In size the flowers vary slightly, and those of No. 10,368 are from 1.5 to $2.5 \mathrm{~cm}$. across and no larger than those of some plants of the f. japonicum. In fact this new form is the link connecting the var. Kaempferi with the wild f. japonicum. In certain localities this multi-colored form is abundant, as in those cited, and also round Tajimi, near the city of Nagoya, in province Owari. Curiously, where this form is plentiful the typical red-flowered Kaempferi is entirely absent or nearly so. The soil around Ajisu is rotten granite, round Tajimi and Futagawa gravel and brick clay; on the same formation and in the same general neighborhood Kaempfer's Azalea grows in great plenty. On Nishi-Kirishima, where the manycolored f. japonicum and the typical var. Kaempferi both grow, the soil is volcanic ashes and detritus. It is plain, therefore, that soil has nothing to do with the variation in the color of the flowers, neither has altitude nor exposure. The cause would appear to be innate and not due to external conditions.

I collected much seed of this new form from the neighborhood of Ajisu, and this has been distributed in England and in this country by the Arnold Arboretum, and many plants have been raised. If it should prove hardy this form may prove the forerunner of a new race of welcome colors among hardy Azaleas.

A form with double flowers is:-

Rhododendron obtusum var. Kaempferi f. plenum Wilson, n. comb.

Rhododendron Kaempferi var. plenum Nakai in Tokyo Bot. Mag. XXIX. [261] (1915). 
Japan: Kyushu, prov. Chikugo, Koradai, near Kurume, April, 1918, K. Akashi; without locality, May, 1918, B. Miyazawa.

In this plant the calyx is normal but the stamens and pistil are petaloid. Akashi's specimen has rather small flowers salmon-red in color and is from a spontaneous plant. Miyazawa's is in size and color typical Kaempferi with double flowers. He told me this was also from a wild plant.

A form with petaloid calyx forming hose-in-hose flowers and which also has been found wild is: -

Rhododendron obtusum var. Kaempferi f. Komatsui Wilson, n. comb.

Rhododendron Kaempferi var. Komatsui Nakai in Tokyo Bot. Mag. XXIX. [261] (1915).

A form with monstrous flowers may be designated:-

Rhododendron obtusum var. Kaempferi f. monstrosum Wilson, n. f.

Korea: prov. Keiki, cultivated, said to have come from Japan, Agricultural Experimental Station, Suigen, May 24, 1917, E. H. Wilson (No. 8482).

In this curious plant the corolla is white and has a petaloid calyx, the pistil is abnormal and in most flowers is changed to a staminode, the stigma being changed to a swollen, abortive anther which is often conspicuously aristate. The flowers though hose-in-hose are as large as those of ordinary Kaempferi. Possibly this is the same as Nakai's f. album.

A form with abortive or nearly abortive corolla is: -

Rhododendron obtusum var. Kaempferi f. cryptopetalum Wilson, n. comb.

Rhododendron ledifolium $\delta$. cryptopetalum Maximowicz in Mém. Acad. Sci. St. Pétersbourg, sér. 7, XVI. No. 9, 36 (Rhodod. As. Or.) (1870). - Matsumura, Ind. Pl. Jap. II. pt. 2, 462 (1912).

Rhododendron Kaempjeri f. $\zeta$. Kinshibe Komatsu in Tokyo Bot. Mag. XXXII. [43] (1918).

Japan: Hondo, prov. Kawachi, Yamomoto, cultivated, May 8, 1918, E. H. Wilson; prov. Musashi, Hatagaya, cultivated, April 29, 1914, E. H. Wilson (No. 6593).

This is a monstrous form long cultivated in Japanese gardens under the name of " Kinshibe-tsutsuji." The corolla may be entirely suppressed or represented by from 1 to 5 deeply laciniate, strap-shaped lobes. The stamens vary from 5 to 10 (usually 7 to 10); the filaments are variable in length, often curled, bright crimson in color, and may be either normal in shape or slightly flattened and petaloid; the anthers are yellow. It has no garden value, being simply a curiosity. As to its specific identity there can be no question, and I am at a loss to understand why Maximowicz referred it to $R$. ledifolium (R. mucronatum G. Don). 
A form with purple flowers and from 5 to 10 stamens is: Rhododendron obtusum var. Kaempferi f. mikawanum Wilson, n. comb.

Rhododendron indicum var. mikawanum Makino in Tokyo Bot. Mag. XXIII. 251 (1909).

Rhododendron Kaempferi var. milkawanum Makino in Jour. Jap. Bot. I. 18 (1917). - Komatsu in Tokyo Bot. Mag. XXXII. [37] (1918).

Rhododendron purpureum Komatsu in Tokyo Bot. Mag. XXXII. [16] (1918).

Rhododendron poukhanense Komatsu l.c. [12] (1918), as to the Japanese plant, not Léveillé.

Rhododendron poukhanense f. obtusifolium Komatsu l. c. [37] (1918).

Rhododendron poukhanense f. acutifolium Komatsu l. c. [38] (1918).

Rhododendron scabrum Nakai in Tokyo Bot. Mag. XXXIII. 207 (1919), not G. Don.

Rhododendron scabrum var. Kaempferi, f. 1. purpureum Nakai l. c. 208.

Japan: Hondo, prov. Suruga, near Ashitake-yama, lower slopes of Mt. Fuji, June 20, 1918, H. Suzuki; prov. Musashi, Ome, near Tokyo, May 31, 1918, E. H. Wilson.

This is a form of the common Mountain Azalea of Japan having purple flowers and from 5 to 10 stamens. It is found here and there mixed with the type and is occasionally cultivated, being known as the "Murasaki Yama-tsutsuji" (Purple Hill Azalea). It is in cultivation in the Arnold Arboretum from plants I brought from Japan in the spring of 1919. The increase in the number of stamens is interesting, and is another instance of the extraordinary range of variation which obtains in $R$. obtusum. In Tokyo I saw specimens from Hangno which Komatsu refers to $R$. poukhanense, but it is not that species and I could find no character by which to separate them from Makino's variety. The material was collected on the Chichibu Mountains in the western part of Musashi province. It has flowers in pairs, red-purple in color, with dark purple anthers; the leaves are rather long, lanceolate and glabrescent, and the pedicels and calyx are clothed with gray pubescence. Komatsu's $R$. purpureum is based on a specimen collected in Yumato province. It has the foliage of typical var. Kaempferi, pale rose-purple colored flowers each with from 7 to 10 stamens; the calyx-lobes are lanceolate, acuminate and erose.

Nakai in the Tokyo Bot. Mag. (XXXIII. 207 [1919]) identified this plant with R. scabrum G. Don. I do not understand how he arrived at this conclusion unless he was guided solely by the color of the flowers. This f. mikawanum never has flowers 3 inches in diameter, which is the size given by G. Don, neither are the leaves coriaceous. It seems to me that the plant described by G. Don as $R$. scabrum is that which Miquel later described as R. sublanceolatum; from the description I do not see how it can have anything to do with $R$. obtusum var. Kaempferi or any of its forms.

A hybrid race with richly colored flowers of small to medium size is: -

$\times$ Rhododendron Sanderi Wilson, n. hyb.

Rhododendron Simsii " Garnet" $\times R$. oblusum Planchon.

This is an interesting and valuable race that has been raised and developed at Holm Lea, Brookline, the home of Professor C. S. Sargent. About thirty-five years 
ago the gardener, Charles Sander, collected seeds from the Holm Lea collection of "Indian Azaleas" and from them raised many plants. Among these when they flowered were two of dwarf, compact habit which produced relatively small flowers $(3 \mathrm{~cm}$. diam.) carmine-red or crimson-lake in color. In the Holm Lea collection was the well-known "Indian Azalea Decora" of European origin and introduced into the garden of Marshall P. Wilder, Dorchester, Mass., about 1847. It is highly probable that this was the parent of the two Azaleas above mentioned. The best of these two Sander named "Garnet." This he crossed with an unknown Azalea having small red flowers obtained from M. Atkinson, gardener for Mr. John L. Gardner, Brookline, Mass., which to-day Sander thinks was $R$. obtusum Planch. After a close study of the race I think this conclusion is correct. The best of the hybrids from the above parents were crossed with $R$. obtusum f. album Schneid. and gave rise to forms with rose-pink flowers. In more recent years the well-known " Hinodegiri" has been used with excellent results. The outcome of some three decades of hybridising, selecting and recrossing is a race of beautiful Azaleas of compact twiggy habit with flowers from 2.5 to $4.5 \mathrm{~cm}$. in diameter in varying shades of rose-pink, salmon, red, scarlet and fiery crimson. Among the scarlet and crimsons are deeper and richer shades than I have seen among any of the Azaleas of China and Japan. The influence of $R$. Simsii forms is seen in the number of stamens, which varies from 5 to 10 and is inconstant on the same individual; also in the size of the flowers and in the ease with which the plants may be forced into blossom during the winter and early spring months. Some of the forms have flowers no larger than those of $R$. obtusum, though in the majority the fiowers exceed in size those of that plant. The race is singularly attractive and highly ornamental, and it needs no expert knowledge to predict for $\times R$. Sanderi a great future. Among the best forms are "Suzuki," scarlet maroon, "Hebe," white with rose-red stripe, "Hermione," deep salmon-red, "Ruby " crimson maroon, "Uncas," dark scarlet, "Helena," rose-pink, "Hilda Hedhund," deep pink, "Holm Lea," crimsonmaroon, "Vulcan," salmon-red, "Natalie," salmon, "Muriel," rose-red, "Alice Sargent," bright salmon-red, "Rose Queen," deep rose, "Havemeyer," rose-red, "Broolline," carmine, "Venus," cerise, "Jupiter," fiery-red, "Mars," intense scarlet, "Vivid," scarlet. To this group must be referred the highly appreciated and well-known Azalea "Hexe"1 or "Firefly" of American gardens, which is a hybrid between $R$. obtusum f. amoenum and $R$. Simsii "Duc de Nassau." This favorite Azalea with rich red, hose-in-hose flowers was raised by Otto Forster, Lebenhof, near Scheibbs, Lower Austria, about 1885, and was first extensively cultivated round Dresden. At first it was not particularly esteemed and was used as a stock on which to graft the ordinary "Indian Azaleas" of commerce; later it became one of the most popular varieties, and before the Great War was imported in hundreds of thousands into this country for decorative purposes. It roots freely from cuttings and flowers profusely when quite small. One of its parents, Azalea "Duc de Nassau," is an old variety, having been exhibited in London in June, 1862, by Charles Turner of Slough. There are several other hose-in-hose Azaleas of much the same parentage as "Hexe." One of these, "Vuylestekeana," has been crossed at Holm Lea with "Flambeau," a French variety, with erimson-maroon flowers of medium size. The result is a race with relatively large ( 4 to $6 \mathrm{~cm}$. diam.), hose-in-hose flowers varying in color from intense scarlet to crimson-maroon, and perhaps the most highly colored of all Azaleas.

${ }^{1}$ Azalea indica (Hexe) Ad. Vanden Heede in Rev. Hort. Belg. XXXI. 49, t. (1905).

Azalea Hexe Hort. ex W. Watson, Rhodod. and Azaleas, 67 (1911).

Rhododendron indicum Hexe Millais, Rhodod. 193 (1917). 
Rhododendron Simsii Planchon in $F l$. des Serr. IX. 78 (1854); in Rev. Hort. 1854, 47. - Schneider, Ill. Handb. Laubholzk. II. 506, figs. $331 \mathrm{l}-\mathrm{m}, 332$ a-d (1911). - Rehder in Bailey, Stand. Cycl. Hort. V. 2944 (1916).

Azalea indica Aiton, Hort. Kew, ed. 2, 318 (1810), as to the plant, not Linnaeus. - Sims in Bot. Mag. XXXVI. t. 1480 (1812). - Bentham, Fl. Hongk. 201 (1861), as to the Hongkong plant.

Azalea indica a. punicea Sweet, Hort. Brit. 264 (1827).

Rhododendron indicum var. ignescens Sweet, Brit. Flow. Gard. ser. 2, II. t. 128 (1832). - Rehder \& Wilson in Sargent, Pl. Wilson. II. 547 (1913).

Rhododendron indicum a. puniceum Sweet in Brit. Flow. Gard. ser. 2, II. sub. t. 128 (1832).

Azalea indica ignescens Hovey, Mag. Hort. III. 72 (1837).

Rhododendron Calleryi Planchon in Fl. des Serr. IX. 31 (1854); in Rev. Hort. $1854,66$.

Rhododendron indicum $\beta$. Simsì Maximowicz in Mém. Acad. Sci. St. Pétersbourg, sér. 7, XVI. No. 9, 38 (Rhodod. As. Or.) (1870). - Franchet in Nouv. Arch. Mus. Paris, ser. 2, VI. 77 (1883); Pl. David I. 97 (1884); in Bull. Soc. Bot. France, XXXIII. 235 (1886).

Rhododendron indicum Hemsley in Jour. Linn. Soc. XXVI. 25 (1889), as to the Chinese plant, not Sweet. - Diels in Bot. Jahrb. XXIX. 514 (1900); in Notes Bot.Gard. Edinburgh, VII. 392 (Pl. Chin. Forrest.) (1913). - Pampanini in Nuov. Giorn. Bot. Ital. n. ser. XVIII. 131 (1911). - W. Watson, Rhodod. \& Azaleas, 79 (1911), in part. - Dunn \& Tutcher in Kew Bull. Misc. Inform. add. ser. X. 155 (Fl. Kwangtung and Hongk.) (1914).Millais, Rhodod. 189 (1917), in part.

Azales indica var. Simsii Rehder in Bailey, Cycl. Am. Hort. I. 122 (1900).

Rhododendron indicum var. Matsumura in Tokyo Bot. Mag. XIV. 69 (1900).

Rhododendron indicum var. Tamurai Makino in Tokyo Bot. Mag. XVIII. 102, fig. (1904).

Rhododendron indicum $\gamma$. macranthum subvar. genuinum forma Tamurai Makino in Tokyo Bot. Mag. XXIV. 77 (1910).

Rhododendron indicum var. formosanum Hayata, Icon. Pl. Formos. III. 134 (1913). - Kanehira, Formos. Trees, 321, fig. 9 (1917).

China: Hongkong, Happy Valley, November 5, 1903, C. S. Sargent; without locality, J. G. Champion (Nos. 122, 123, Herb. Kew, Herb. Gray); without locality, C. Wright (No. 195, Herb. Gray, Herb. Kew); April 28, 1914, Mary Strong Clemens (No. 4261, Herb. Bur. Sci. Manila). Kwantung, Canton, March 10, 1835, S. W. Williams (Herb. Gray); same locality, October 27-30, 1916, March 20, 1917, C. O. Levine (No. 438, 599, Herb. Bur. Sci. Manila); Shiuchow, April, 1919, To Kang P'eng (No. 2761, Herb. Bur. Sci. Manila). Chekiang, Pootoo Island, E. Faber; Ningpo, Ning-kan-jou, April 15, 1877, W. Hancock (No. 32, Herb. Kew); Mokan-shan, alt. $500 \mathrm{~m}$. August 3, 1915, F. N. Meyer (No. 1607); without locality, 1845, R. Fortune (Nos. 72, 152, 153, Herb. Kew, Herb. Gray); hills near Taihu Lake, April, 1881, W. R. Carles. Kiangsu, near Shanghai, 
1915, D. Macgregor. Kiangsi, Kuling, alt. 1600 m., July 28, 1907, E. H. Wilson (No. 1682); same locality, 1873, G. Shearer (Herb. Kew). Hunan, Yoku-shan, alt. 70-300 m., February 21, 1918, Dr. Handel-Mazzetti (No. 480). Hupeh, north and south of Ichang, alt. 30-1300 m., May and November, 1907, E. H. Wilson (No. 3474); same locality, A. Henry (Nos. 782, 1160, Herb. Kew, Herb. Gray); Changyang Hsien, thickets, alt. 1300 m., May and November, 1907, E. H. Wilson (No. 3472); Changlo Hsien, cliffs, alt. 600-1300 m., May, 1907, E. H. Wilson (No. 3472 ${ }^{\mathrm{a}}$ ); Patung Hsien, A. Henry (No. 1416, Herb. Kew); Nanto and mountains to northward, $A$. Henry (No. 3194, Herb. Kew); Hsing-shan Hsien, alt. 1000-1800 m., May 14, December, 1907, E. H. Wilson (No. 569); " Kao-hien-scian," alt. 800 m., May, 1907, C. Silvestri. Szech'uan, Chungking, 1885, F. S. A. Bourne (Herb. Kew); Kiating Fu, alt. 300-800 m., May, 1908, E. H. Wilson (No. 3475); Mt. Omei, May, 1904, E. H. Wilson (Veitch Exped. No. 5143); without locality, A. von Rosthorn (No. 2148); Yunnan or Kueichou, 1911, A. Hosie (Herb. Kew). Yunnan, Menztsze, alt. $1500-2000 \mathrm{~m}$., A. Henry (Nos. $9900^{\mathrm{b}}, 9900^{\mathrm{c}}, 9900^{\mathrm{e}}$, Herb. Kew, Herb. Bur. Sci. Manila); same locality, alt. 1600-2300 m., April, 1893, W. Hancock (No. 155, Herb. Kew); Milê, A. Henry (No. 9900d); " Momyen," June 3, 1868, D. J. Anderson (Herb. Kew); near Tali Fu, Tsang-chan, alt. 2500 m., J. M. Delavay (No. 1122, Herb. Kew); Tali Fu, alt. 2200-2600 m., cultivated, G. Forrest (No. 4173); "Ho-yeh-shui," north end of Lichiang Valley, alt. $2900 \mathrm{~m}$., cultivated by Mossoo natives, May, 1906, G. Forrest (No. 2282, Herb. Kew); without locality, G. Forrest (Nos. 7832, 11,824); 1910, R. P. Maire (Nos. 3713, 3775, Herb. Bur. Sci. Manila).

Formosa: prov. Koshun, South Cape, Schmuser ex A. Henry (No. 588 in part, Herb. Kew).

Cultivated: "Jardin du Luxembourg, Orangerie, 14 avril, 1822, 27 avril, 1823 " ex Herb. J. Gay (Herb. Kew).

This species grows in all the temperate parts of China and in south Formosa, and a variety (eriocarpum Wils.) on the Kawanabe Islands off Liukiu Oshima, but it has not been found in Japan or Korea. It is particularly abundant in the area of the Yangtsze Valley from near Ningpo to Mt. Omei in the far west. Hancock, on a specimen, states that " the Ningpo hills are absolutely crimson in places with this shrub "; the same is true of the Lushan hills round Kiukiang and of the region north and south of Ichang. It delights in rocky places, preferably cliffs, thin dry woods and thickets, blossoms profusely, and its wealth of red flowers makes it one of the most conspicuous of all shrubs. The habit is twiggy and much-branched with a maximum height of three metres, but averaging about half this height. The leaves are variable in size and with the shoots are clothed with appressed, 
strigose, gray to shining brown hairs. At low altitudes the leaves are comparatively large, from lanceolate to ovate-elliptic, and are all persistent; at its upper altitudinal limit the leaves are much reduced in size, and nearly all fall off in the late autumn. The leaves immediately below the winterbuds are small, relatively thick, obovate to oblanceolate and more persistent than the other form of leaves. The flowers are clustered, from two to six together, at the end of the shoots and all I have seen are fairly uniform in color. The corolla is broad-funnel shape, varying in color from rose-red through bright to dark red. The calyx varies from an inconspicuous rim to a length of $5 \mathrm{~mm}$.; the stamens are normally ten, rarely eight, never fewer, as long or nearly as long as the corolla but shorter than the style. In central China it is generally known as the "Yin-shan-hung." Millais says that Forrest states under Nos. $4173,4173^{\text {a }}$, from plants cultivated by Chinese in the Tali Valley, that the color of the flowers is "rose to white." In China I have never seen wild an albino of this species; Forrest's No. 4173 in Herb. Kew is described as having rose-colored flowers. The Formosan specimen cited from A. Henry in Herb. Kew represents Hayata's var. formosanum, the type of which I have seen in Tokyo. It is indistinguishable from typical $R$. Simsii so abundant in China, but in Formosa known only from the extreme southern end of the island.

For nearly a century and a quarter this plant has usurped the name indicum, and in books is almost hopelessly confused with the true $R$. indicum Sweet, with $R$. obtusum Planchon and its varieties, and with $R$. scabrum G. Don (R. sublanceolatum Miquel). The first mention of the Chinese plant I can find is in Macartney's Embassy to China, II. 524 (1797), where Azalea indica is recorded as collected in the provinces of Kiangsi and Canton (Kwangtung) in 1793. In all probability it is the Chinese species that was introduced into Kew "by the Hon. Court of Directors of the East India Company" in the ship "Cuffnels," Captain Wellbank (Aiton, Hort. Kew, ed. 2. 318 [1810]), though Aiton's description is of the true R. indicum Sweet. Sims was the first to figure the Chinese species (Bot. Mag. t. 1480 [1812]) under the erroneous name of Azalea indica, and states that it was a rare plant in England and that the only one that had flowered was in the collection of James Vere, Esq. In the Kew Herbarium there are two specimens from the Jardin du Luxembourg collected in 1822 and 1823. These are the oldest cultivated specimens I have seen. Sweet in 1832 gave it a varietal name, and says that the plant was imported in the East India Company's ship "Orwell " from China by Mr. Tate. This Mr. Tate was a nurseryman in Sloane Square, London, and the master of the ship "Orwell" was Captain Farrer, who brought a number of Chinese plants including other Azaleas to England and handed them over to Tate. In Braam's Icones plantarum, issued in 1818, there is a figure (t. 27) of a red-flowered Azalea. The drawing is very crude and, while it probably is meant for $R$. Simsii, it might represent any Azalea with red flowers.

The Chinese Azalea appears to have remained rare in the Occident for several decades. In 1837, under the name of Azalea indica ignescens, it was cultivated in America by Marshall P. Wilder, Dorchester, Mass. Fortune, from 1843 to 1856, introduced into England from Chinese gardens many Azaleas of different kinds, and these gave great impetus to the cultivation of these ornamental plants. The so-called "Indian Azaleas" of western gardens have been originated almost entirely from $R$. Simsii since about 1850 , chiefly in Belgium, but some in France and others in Germany.

There is a very considerable literature on "Indian Azaleas" and at least one illustrated book (Iconographie Azalées de L'Inde by Auguste van Geert, published in 1882). Planchon (in Fl. des Serr. IX. 77 [1854]) gives a brief history of them, and enumerates varieties in the collections of M. Margottin, M. Delessert, and M. Michel. Some of them were forms of the true $R$. indicum, others of $R$. phoe- 
niceum, and a few of $R$. Simsii; several are recorded as presumed hybrids between $R$. phoeniceum and $R$. Ledifolium ( $R$. mucronatum G. Don) and between $R$. phoeniceum and $R$. Danielsianum ( $R$. indicum Sweet) but such hybrids are unknown to-day and probably never existed. In $\mathrm{La}$ Belgique Horticole for 1865 (XV. pp. 174-192), there is an excellent article by M. Edouard André with a list of varieties and the names of the originators. In the various volumes of Flore des Serres are many colored figures and notes chiefly by Louis van Houtte. In fact in all garden periodicals from about 1850 on, there are many references and figures of these plants. However, scientific exactness is wanting and much of their early beginnings is obscure. As far as I can discover the introduction into England of the striped-flowered Azalea vittata by Fortune in 1850 or 1851 led to the raising of seedlings. Further impetus was given by the advent the same years of $A$. vittaia Bealii with red and white striped flowers. Many of the best varieties are branch sports perpetuated by grafting. From the crossing of red and white flowered varieties many variegated forms have originated. One of the most successful breeders of "Indian Azaleas" of commerce was Mr. Joseph Vervaene of Ghent, whose work is fittingly commemorated by the lovely Azaleas "Vervaeniana," and "Vervaeniana' alba." Other names immutably connected with the raising and perfecting of the "Indian Azaleas" of commerce are Messers Knight \& Perry, Ivery and Rollisson in England; L. Eeckhaute, Haerens, Van Houtte, Van Geert, A. Verschaffelt, J. de Kneep and Van der Cruyssen in Belgium; Lesebe, Truffaut, H. de May and Mabire in France; Messers Schulz, E. Liebig, Seidel and Rose in Germany.

The varieties are legion, and each year adds materially to the number. All the modern ones have been raised in Belgium or Germany, where they are cultivated by the millions and exported to almost all parts of the world. Prior to 1914 more than two and a half million plants were annually exported from Belgium alone. In Germany a Eurhododendron (Cunningham's White) is much used as a stock for these "Indian Azaleas," but not in Belgium, where $R$. phoeniceum and its f. concinnum are chiefly so employed. According to J. Breck (in The Horticulturist, I. 512 [1847]), Marshall P. Wilder imported from Germany by way of England and cultivated in his garden in Dorchester, Mass., in 1847, Azalea "Optima" with dark scarlet flowers, Azalea "Prince Albert" with scarlet flowers, and Azalea "Alba Insignis" with large white flowers. The first two were undoubtedly derivatives of $\boldsymbol{R}$. Simsii and representatives of the "Indian Azaleas" of to-day, and the first introduced into America so far as I can discover. The third was probably a form of R. mucronatum. Hovey (Mag. Hort. XIV. 284 [1848]) records that on May 13, 1848, Marshall P. Wilder exhibited before the Massachusetts Horticultural Society Azalea "Decora," another Indian Azalea. A plant of this was acquired by Ignatius Sargent, and its descendants are still in the Holm Lea collection.

Among the typical large-flowered forms of "Indian Azaleas" of to-day I can detect no influence of any species other than $R$. Simsii, though without question $R$. phoeniceum and its forms have been used. Those with smaller flowers, especially the hose-in-hose kinds like "Hexe" and "Vuylstekeana," are without doubt hybrids between forms of $R$. Simsii and $R$. obtusum f, amoenum. It is probable also that typical $R$. obtusum has been employed. $R$. mucronatum and numerous named forms of it are loosely designated Azalea indica, but in the evolution of the "Indian Azalea" of present-day gardens neither this species nor the true $A$. indica of Linnaeus have had any part.

Rhododendron Simsii var. vittatum Wilson, n. comb.

Azalea vittata Fortune, Tea Districts of China, 330 (1852).

Azalea indica vittata Van Houtte in Fl. des Serr. IX. t. 886 (1854). - Millais, Rhodod. 259 (1917). 
Azalea indica vittata punctata Van Houtte in $F l$. des Serr. IX. t. 888 (1854).

Rhododendron vittatum Planchon in Fl. des Serr. IX. 82 (1854); in Rev. Hort. 1854, 66. - Maximowicz in Mém. Acad. Sci. St. Pétersbourg, sér. 7, XVI. No. 9, 49 (Rhodod. As. Or.) (1870). - Millais, Rhodod. 259 (1917).

Rhododendron vittatum var. b. punctata Planchon, in Fl. des Serr. IX. 82 (1854); in Rev. Hort. 1854, 66.

Azalea vittato-punctata Lemaire in Ill. Hort. I. t. 20 (1854).

Cultivated: Hort. Holm Lea, May 20, 1918, A. Rehder; Hort. Berckmans, Augusta, Georgia, March 30, 1908, C. S. Sargent.

This variety has larger calyx-lobes than is usual in the species, but I have wild specimens of the type with an equally large calyx. The most prominent distinguishing feature is the color of the flowers. This is white, striped with lilac-purple, often irregularly so; sometimes the flowers are pure white or pure lilac-purple on the same branch, occasionally they are dotted or blotched with color. Planchon says it has been in possession of $M$. Paillet since 1844, and then adds that it was one of Fortune's introductions to England. Now Fortune did not land in China until July, 1843, so it would seem that there was something wrong with Planchon's date or that it was introduced before Fortune's first visit. In all probability the date is wrong. According to Fortune's account in his Tea Districts of China it was in April, 1850, that he visited the Pou-shan gardens near Shanghai and saw this Azalea in flower. However, he had been to these gardens on his first visit to China (1843-45), but if he sent this variety of Azalea to England on that occasion there is no available record of the fact. In all probability $\mathbf{M}$. Paillet's plant was R. indicum var. variegatum. Fortune's plant did not reach England before 1850 or 1851 so far as I can discover, and its acquisition according to the books led to the raising of many seedlings. According to Hovey (Mag. Hort. XXI. 301 [1855]) an Azalea vittata rosea was exhibited for the first time in Philadelphia on April 17, 1855, by Mr. Buist. It has long been grown in the Berckmans Nurseries, Augusta, Georgia, and in the collection at Holm Lea. The type appears to have been lost to English gardens until recently, when Professor Sargent sent it to Kew and elsewhere.

A form in which the flowers are striped with red is:-

Rhododendron Simsii var. vittatum f. Bealii Wilson, n. comb.

Azalea Bealii Fortune, Tea Districts of China, 330 (1852), - Lemaire in Ill. Hort. I. t. 8 (1854).

Rhododendron vittatum var. g. Bealii Hort. apud Planchon in Fl. des Serr. IX. 82 (1854); in Rev. Hort. 1854, 66.

Azalea vittata Bealii Morren in Belg. Hort. XVI. 1, t. (1866).

This is another of Fortune's introductions to Messers Standish \& Noble of Sunningdale Nurseries from Pou-shan gardens, Shanghai, in 1850 or 1851, and is characterised by its white flowers striped with red. This plant also has been a useful parent in the evolution of the present-day race of "Indian Azaleas," as shown by the variety "Fürstin Baro Trysky," for example. It was imported into America by C. M. Hovey, Boston, Mass., in 1855.

A variety with white to rose-colored flowers and geographically widely removed from the type is: -

Rhododendron Simsii var. eriocarpum Wilson, n. comb.

Rhododendron indicum var. eriocarpum Hayata, Icon. Pl. Formos. III. 134 (1913). 
Japan : Kawanabe Islands, Suwanose-shima, May, 1917, H. Ushiwo (No. $\left.1^{\circ}\right)$; Takara-shima, May $4,1917, H$. Ushiwo $\left(\right.$ No. $\left.1^{\mathrm{d}}, 1^{\mathrm{e}}\right)$; Tairashima, May, 1917, H. Ushiwo (No. $1^{\mathrm{f}}$ ).

These specimens were collected for me by Forestry-officer Ushiwo by courtesy of Dr. Naito, chief of the Kagoshima forestry bureau, and are excellent, though unfortunately unaccompanied by field notes. The flowers of the Takara-shima specimens are white, those of that from Taira-shima pink or rose-colored. The color of the flowers and of the pubescence more readily distinguish this variety from the type than does the shape of the leaves pointed out by Hayata. I am sorry that I did not see this interesting plant in a wild state and am inclined to the view that ultimately it may prove to be a distinct species. The Kawanabe Islands are a number of small rocky eminences which jut out of the sea south of Yaku-shima toward the Liuknu Islands and have a flora like that of Liukiu (see Jour. Arnold Arb. I. 183-186 [1920]).

Rhododendron atrovirens Franchet in Bull Soc. Bot. France, XXXIII. 235 (1886). - Hemsley in Jour. Linn. Soc. XXVI. 19 (1889). - Millais, Rhodod. 124 (1917).

The species from western Yunnan is unknown to me, except from Franchet's description. It would appear to be intermediate between $R$. Simsii Planch. and $\boldsymbol{R}$. microphyton Franch. It is said to be a large bush or small tree with lanceolate; long-acuminate leaves narrowed to the base and glaucescent on the underside. The flowers are described as red, clustered 3 or 4 together, and each $2.5 \mathrm{~cm}$. or less in diameter. It was discovered by Père Delavay at "Tchen-fang-chan " near Takouan in May, 1882, but apparently has not yet been introduced to cultivation.

Rhododendron lasiostylum Hayata, Icon. Pl. Formos. III. 135 (1913). - Kanehira, Formos. Trees, 321 (1917). - Komatsu in Tokyo Bot. Mag. XXXII [14] (1918).

Formosa: prov. Nanto, between Shushu and Horisha, March 12, 1918, E. H. Wilson (No. 10,020).

This is a pretty pink-flowered Azalea of which I have seen only one plant. It was growing on top of a rock by the trolley line at about $400 \mathrm{~m}$. altitude, and was about $1 \mathrm{~m}$. high and less broad. The branches are slender and twiggy and when young clothed with the usual appressed, flattened chestnut-brown hairs. The young leaves, petioles, pedicels, calyx and ovary are all densely clothed with chestnut-brown pubescence changing to gray. The leaves are dimorphic; the spring leaves are lanceolate to ovate-lanceolate and from 2 to $4.5 \mathrm{~cm}$. long and 1 to $1.5 \mathrm{~cm}$. wide, acute and deciduous; the summer leaves are oblong-obovate to oblanceolate from 2 to 4.5 . cm. long and 1 to $2 \mathrm{~cm}$. wide, rounded and mucronate at apex and cuneate at base; both surfaces are clothed with appressed gray to rufous: brown hairs. The flowers are terminal, three or four together at the end of the branchlet. The corolla is funnel-shape, pink, about $2 \mathrm{~cm}$. long with spreading lobes and about 2.5 . cm. across, the tube being rather less than $1 \mathrm{~cm}$. long. The calyx is variable in size being either nearly obsolete or with distinct, rounded lobes each a millimetre or more long. The stamens are of unequal length, the longest equalling the corolla-lobes and overtopped by the style. It is with considerable hesitation that I identify my specimens with this species. There are many discrepancies but of trivial character the more important being the difference in 
size of the calyx-lobes and of the leaves. I have seen the type specimens in Tokyo but the material is so poor that I could arrive at no definite conclusion in the absence of my own material for comparison.

Rhododendron subsessile Rendle in Jour. Bot. XXXIV.357 (1896).Merrill in Govt. Lab. Publ. (Philipp.) XXIX. 40 (1905). - Millais Rhodod. 249 (1917).

Philippine Islands: Luzon, Prov. Benquet, Baguio, March 1907, 1913, A. D. E. Elmer (Nos. 8595, 14,298); same locality, MayJune, 1916, J. K. Santos (No. 38); same province, Mt. St. Tomas, February 18, 1916, E. C. Leano (Forestry Bureau No. 25,125); same locality, March, 1904, A. D. E. Elmer (No. 5799); same locality, July 1, November 29, 1904 R. S. Williams (Nos. 1223, 2001); same locality, May 10, 1904, P. T. Barnes (No. 922); same locality, April, 1908, H. N. Whitford (Forestry Bureau No. 11,090); Mt. Tonglon alt. $2200 \mathrm{~m}$., November 12, 1905, May, 1911, E. D. Merrill (Nos. 4815, 736); same place, August, 1906, H. M. Curran (No. 5032); same place, December, 1906, E. A. Mearns; same place, December, 1908, M. L. Merritt (No. 14,148); Bucao, alt. 2300 m. January 4, 1909, R. J. Alvarez (No. 18,362); Mt. Pulog, January $3 \& 8,1909$, T. C. Zschokke and M. L. Merritt (Nos. 18,035, 18,172); Pauai, July, 1907, E. A. Mearns (No. 4275); same place, alt. 2100 m., June, 1909, R. C. McGregor (No. 8420); same place, April 17, 1918, J. K. Santos (No. 31,994); District of Lepanto, January 26, 1909, F. W. Darling (No. 16,573); same district, Mt. Data, November 4, 1905, $E . D$. Merrill (No. 4606); prov. Abra, February 8, 1909, M. Ramos (Nos. 7249, 7105); subprov. Bontoc, alt. $1350 \mathrm{~m}$. April 7, 1910, Père $M$. Vanoverber (Nos. 351, 364) - all these numbers in Herb. Bureau Science Manila.

This Philippine species in its pubescence and foliage somewhat resembles, as Dr. Rendle points out, the Japanese $R$. mucronatum G. Don, but it is non-glandular, the flowers are not more than one-third the size and have a minute calyx and a more tubular corolla. Its nearest relative is probably the Formosan $R$. rubropilosum Hayata. It is evidently a twiggy plant and the young branches are clothed with the usual flattened, appressed bristles. The oval to lanceolate persistent leaves are from 1.5 to $3.5 \mathrm{~cm}$. long and from 0.7 to $1.2 \mathrm{~cm}$. wide, acute and mucronate, with alightly recurved margins, the midrib impressed above, prominent below. On adult leaves the upper surface is clothed with appressed white hairs but when young both surfaces are densely covered with rufous-gray, silky hairs. The flowers are in terminal two to several flowered clusters. The corolla is campanulate-funnel-form, with the tube less than $1 \mathrm{~cm}$. long and short spreading lobes, and is said to be from lilac to violet-purple in color; the stamens vary from 6 to 10, are slightly exserted and are overtopped by the graceful, curved style which is villose at the base. The pedicels, calyx and ovary are densely clad with ferrugineous villose and more or less flattened, straight hairs. The 
fruit is conic-ovoid and is densely clothed with rufous, appressed and villose pubescence.

It is widely distributed and very common on the highlands of northern Luzon. It is evidently a very pretty species and ought to be introduced into gardens. The flowers vary considerably in color and No. 364 from Bontoc is said to have white flowers. No. 351, also from Bontoc, has very slender branches and small, elliptic, acute leaves and is very different in appearance from the other specimens. I can find no morphological differences, and it appears to be simply a condition; probably the plant from which the specimen was taken was growing in the crevice of a boulder or of a cliff.

Rhododendron rubropilosum Hayata in Jour. Coll. Sci. Tokyo, XXX. art. 1, 173 (Mat. Fl. Formos.) (1911). - Kanehira, Formos. Trees, 326, fig. 11 (1917). - Komatsu in Tolyo Bot. Mag. XXXII. [16] (1918).

Rhododendron caryophyllum Hayata, Icon. Pl. Formos. III. 130, t. 23 (1913).Kanehira, Formos. Trees, 318, fig. 17 (1917).

Formosa : prov. Kagi, east of Ari-san, alt. $2500-3300 \mathrm{~m}$. February 2 and 4, October 26, 1919, (Nos. 9728, 9779, 10,939); same locality, June, 1914, U. Faurie (Herb. Bur. Sci. Manila).

On the grass-clad mountain-slopes east of Ari-san this species is common between altitudes of 2300 and $3300 \mathrm{~m}$. but I did not see it elsewhere. It is a narrow shrub from 1 to $3 \mathrm{~m}$. tall, with twiggy, rigid, ascending branches, which when young are densely covered with appressed, flattened, gray to red-brown hairs. The leaves are persistent, scattered on the free-growing shoots and crowded at the tip of the branchlets; in shape they vary from oblong-lanceolate to elliptiolanceolate and are from 1 to $4 \mathrm{~cm}$. long and from 0.5 to $1.7 \mathrm{~cm}$. wide, acute, tipped with a glandular mucro and narrowed at base; the upper surface is dark green, with scattered, appressed, pale gray hairs and the underside is pale green and clothed with flattened, appressed, gray to brown strigose hairs, which are especially prominent on the midrib. The petiole is densely clad with appressed, flattened hairs similar to those on the branches. The bud-scales of the flowers are pubescent but not glandular. The flowers are of medium size, pink spotted with rose, shortstalked and borne several together at the end of the branchlet; the corolla is funnel-shape, with spreading lobes, and from 1.5 to $2.5 \mathrm{~cm}$. across. Hayata gives the number of stamens as 10 but on my specimens I find 7 or 8 only; they are of unequal length but shorter than the corolla. The pistil overtops the stamens and has a relatively stout, slightly curved style, villose at the base, and the ovary is densely clothed with pale gray soft hairs. The fruit is ovoid-conic, from 0.5 to $0.8 \mathrm{~cm}$. long and densely clothed with shaggy, gray-brown hairs. The type specimen of $R$. caryophyllum which I have seen, has smaller leaves and flowers than is usual in the species which is due to the fact that the specimens came from a wind-swept slope near the altitudinal limits of the species. My No. 9779 is similar. In late October I found many plants in full bloom and apparently it is precocious in its habit of flowering. I collected seeds, and plants of this species are now growing in the Arnold Arboretum and in several gardens in England. They will not be hardy except in favored localities like Cornwall and California.

Rhododendron tosaense Makino in Tokyo Bot. Mag. VI. 53 (1892); in XVIII. 101 (1904). - Schneider, Ill. Handb. Laubholzk. II, 506 
(1911). - Matsumura, Ind. Pl. Jap. II. pt. 2, 465 (1912). - Komatsu in Icon. Pl. Koisikav. II. 91, t. 130 (1915); in Tokyo Bot. Mag. XXXII. [17] (1918).

Japan: Shikoku, prov. Tosa, round Kochi, sea-level to $1000 \mathrm{~m}$. altitude, November 20, 1914, E. H. Wilson (No. 7801).

A twiggy, eglandular shrub growing from 0.3 to $2.5 \mathrm{~m}$. but usually from 1 to $1.5 \mathrm{~m}$. tall, with slender branches clothed with appressed, straight gray to graybrown hairs. The leaves are scattered on the shoots and free-growing branches and crowded at the end of the branchlets. They are more or less deciduous and change in the autumn to purplish crimson; those formed in the spring are oblanceolate or lanceolate from 1.2 to $3.5 \mathrm{~cm}$. long and from 0.5 to $1 \mathrm{~cm}$. broad and are acute and clothed with appressed, straight, gray hairs; the summer leaves are linear to oblanceolate from 0.5 to $1 \mathrm{~cm}$. long and from 1 to $5 \mathrm{~mm}$. wide. The flowers are produced in clusters of from 2 to 6 , but occasionally are solitary. The corolla is lilac-purple, about $3 \mathrm{~cm}$. across. The pedicels are short and the calyx is very small and clothed with long, straight white hairs. The stamens vary in number from 5 to 8 , are of unequal length, included and overtopped by the style which is exserted. The fruit is ovoid, about $9 \mathrm{~mm}$. long, clothed with appressed, straight hairs and subtended by the persistent calyx-lobes.

The species is abundant on the lower mountain-slopes of Tosa province, Shi$\mathrm{koku}$, from sea-level to altitudes of $1000 \mathrm{~m}$. On exposed slopes it is dwarf and dense in habit, but in thickets it is tall and loosely branched. The summer leaves are minute and with the slender twiggy branchlets easily distinguish this species from others. I have seen a few flowers, but the color is not attractive though doubtless in spring when covered with blossoms, the plant would have a charm of its own. I saw plenty of it in November, 1914, and collected seeds for the Arnold Arboretum. These were distributed but the plants raised here have not proved hardy.

Rhododendron serpyllifolium Miquel in Ann. Mus. Lugd.-Bat. II. 165 (1865-66); Prol. Fl. Jap. 97 (1866-67). - Maximowicz in Mém. Acad. Sci. St. Pétersbourg, sér 7, XVI. 42, t. 4, figs. 18-25 (Rhodod. As. Or.) (1870). Franchet \& Savatier, Enum. Pl. Jap. I. 292(1875).Hooker f. in Bot. Mag. CXXII. t. 7503 (1896). - Boissier in Bull. Herb. Boiss. V. 919 (1897). - Matsumura in Bot. Mag. Tokyo XIV. 69 (1900); Ind. Pl. Jap. II. pt. 2, 464 (1912). - Schneider, Ill. Handb. Laubholzk. II. 507, fig. 333 a-d (1911). - Bean, Trees \& Shrubs Brit. Isl. II. 378 (1914). - Millais, Rhodod. 240 (1917). — Komatsu in Tokyo Bot. Mag. XXXII. [15] (1918).

Azalea? serpyllifolia A. Gray in Perry, Jap. Exped. II. 315 (1857); in Mem. Am. Acad. n. ser. VI. 399 (1858-59). - Masters in Gard. Chron. n. ser. XVII. 429 (1882).

Japan: Kyushu, prov. Osumi, Mt. Takakuma, March, 1912, $K$. Toyohira; prov. Hizen, Mt. Unzen, April 14, 1914, K. Sakurai; Nagasaki, cultivated, 1863, C. Maximowicz (Herb. Kew). Hondo, prov. Settsu, near Kobe, April, 1875, H. N. Moseley (Herb. Kew); prov. 
Idzu, May 19, 1853, C. Wright (Herb. Gray); same place, cultivated, April, 1854, Messers Williams \& Morrow (Herb. Gray, type); Mt. Amagi, April 27, 1913, K. Sakurai; prov. Sagami, Hakone, April and May, 1875, H. N. Moseley (Herb. Kew).

Cultivated: Arnold Arboretum, flowered in greenhouse, March 14, 1907; Royal Gardens, Kew, April 14, 1896 (Herb. Kew, type of Bot. Mag. t. 7503).

During my travels in Japan I did not see this pretty little species in a wild state. On the volcanic mountains of the Hakone region and on those of Idzu province, especially Amagi-san, it is said to be common. This seems to be the northern limit of its range. Matsumura gives two or three other localities in Hondo but I have seen no specimens except one from near Kobe which probably came from a cultivated plant. In the south island of Kyushu it grows on the volcanie Mt. Unzen near Nagasaki, and on Mt. Takakuma in the southern province of Osumi. Matsumura records it from Okinawa Island in Liukiu but I have seen no material from there. In Japan it appears to be confined to purely volcanic 8oils. It is also frequently cultivated there, especially in the gardens of the peasantry.

According to Messers Williams and Morrow its Japanese name eignifies "Rice Azalea" and has reference to the leaves which are minute and smaller than those of any other Japanese species. It was introduced into cultivation in England by Messers Veitch, presumably through their collector Charles Maries, and flowered for the first time in England in 1882. Later it was introduced to America but is still very rare. In the Arnold Arboretum it has not proved hardy. The figure in the Botanical Magazine gives a very good ides of this species.

Differing from the type in color of the corolla only is: -

Rhododendron serpyllifolium var. albiflorum Makino in Tokyo Bot. Mag. XXII. 57 (1908). - Schneider, Ill. Handb. Laubholzk. II. 507 (1911). - Komatsu in Tokyo Bot. Mag. XXXII. [15] (1918).

Of this I have seen only Makino's type which he says is from the mountaing of western Japan. Makino names it in the vernacular the "Shirobana-unzentsutsuji."

Rhododendron Nakaharai Hayata in Jour. Coll. Sci. Tokyo XXV. art. 19, 153 (Fl. Mont. Formos.) (1908). - Millais, Rhodod. 216 (1917).Kanehira, Formos. Trees, 325, fig. 15 (1917).-Komatsu in Tokyo Bot. Mag. XXXII. [14] (1918).

Rhododendron serpyllifolium Hayata in Tokyo Bot. Mag. XX. 72 (1906), not Miquel.

\section{Formosa: prov. Taihoku, Mt. Shichisei ex Hayata.}

I did not see this plant growing wild but in Tokyo examined the type specimen and consider it to be a good species. As the author points out it is nearest to $R$. serpyllifolium Miq. from which it is at once distinguished by its larger flowers, each with 10 stamens. 
Rhododendron Tschonoskii Maximowicz in Mém. Acad. Sci. St. Pétersbourg, sér. 7, XVI. 42, t. 3, figs. 8b-14 (Rhodod. As. Or.) (1870); in Bull. Acad. Sci. St. Pétersbourg, sér. 3, XV. 230 (1871).Franchet \& Savatier, Enum. Pl. Jap. I. 295 (1875). - Boissier in Bull Herb. Boiss. V. 919 (1897). - Matsumura, Pl. Nikko, 71 (1894); Ind. Pl. Jap. II. pt. 2, 465 (1912). - Schneider, Ill. Handb. Laubholzk. II. 507, fig. 332 l-o (1911). - Bean, Trees and Shrubs Brit. Isl. II. 383 (1914). - Millais, Rhodod. 256 (1917). - Nakai in Tokyo Bot. Mag. XXXI. 244 (1917); Fl. Syl. Kor. VIII. 46, t. 17 (1919). - Komatsu in Tokyo Bot. Mag. XXXII. [15] (1918).

Azalea Tschonoskii O. Kuntze Rev. Gen. II. 387 (1891).

Rhododendron trinerve Franchet apud Boissier in Bull. Herb. Boiss. V. 92 (1897).

Rhododendron Tschonoskii a. typicum Makino in Tokyo Bot. Mag. XVIII. 66 (1904).

Rhododendron Tschonoskii a. typicum a. pentamerum Makino l.c. - Matsumura, Ind. Pl. Jap. II. pt. 2, 465 (1912).

Rhododendron Tschonoskii a. typicum b. tetramerum Makino l. c. - Matsumura l. $c$.

Rhododendron Tschonoskii $\beta$. trinerve Makino in Tokyo Bot. Mag. XVIII. 66 (1904). - Schneider, Ill. Handb. Laubholzk. II. 507 (1911).

Rhododendron Tschonoskii $\beta$. trinerve a. pentamerum Makino l.c. - Matsumura l. $c$.

Rhododendron Tschonoskii $\beta$. trinerve b. tetramerum Makino l. c. - Matsumura l. c.

Rhododendron Tschonoskii var. tetramerum Komatsu in Tokyo Bot. Mag. XXXIY. [15] (1918).

Japan: Shikoku, prov. Tosa, Nakatsu-san, June 20, 1889, $K$. Watanabe (Herb. Gray). Hondo; prov. Ettchu, Mt. Tateyama, July 23, 1884, (Herb. Kew); prov. Shinano, Tsubakura-dake, alt. 1300-1600 m., not common, September 15, 1914, E. H. Wilson (No. 7455); Hattasan, July 13, 1894, U. Faurie (No. 13,356); Mt. Asama, July, 1904, U. Faurie (No. 5831); prov. Shimotsuke, Nikko region, Lake Yumoto, June 22, October 18, 1914, E. H. Wilson (No. 7657); same locality, November 6, 1892, C. S. Sargent; Lake Chuzenji, August 12, 1905, J. G. Jack; Mt. Nyoho, August 3, 1909, K. Sakurai; prov. Uzen, Adzuma-san, alt. 800-2000 m. July 20, 1914, E. H. Wilson (Nos. $7233,7234,7235)$; mountains round Yamagata, July 12, 1889, $U$. Faurie (No. 4444) ; prov. Rikuchu, slopes of Hayachine-san, alt. 13002000 m. September 28, 1914, E. H. Wilson (No. 7583); Mt. Iwate July 16, 1903, S. Arimoto (Herb. Gray); high mountains, 1865, Tschonoskii ex Maximowicz (Herb. Kew, Herb. Gray, co-type); prov. Mutsu, Nambu, Shichinoki, June 23, 1889, U. Faurie (Herb. Kew); 
Lake Towada, June 25, 1894, U. Faurie (No. 13,279, Herb. Kew); Hakkoda-san, alt. $1600 \mathrm{~m}$. July 5, 1914, E. H. Wilson (No. 7122); same locality, U. Faurie (No. 875, Herb. Kew). Hokkaido, prov. Oshima, Esashi, August 4, 1890, K. Miyabe \& Y. Tokubuchi (Herb. Gray); prov. Ishikari, near Sapporo, September 17, 1892, C. S. Sargent; Masuzan, July 30, 1897, U. Faurie (No. 636).

Korea : prov. South Keisho, Chiri-san, peak Ten-no-bo, alt. $1845 \mathrm{~m}$. November 16, 1917, E. H. Wilson (No. 9595); same place, July 30, 1913, T. Nakai.

Cultivated: Arnold Arboretum (No. 3691); Royal Gardens, Kew, July 1, 1910; Gardens, Tokyo, May 31, 1882, K. Miyabe.

This is an alpine or subalpine species that grows on most of the high mountains in Hondo from Shinano northward; in Hokkaido it grows sparingly as far north as the mountains round Sapporo. From Shikoku I have seen but one specimen and it is not reported from Kyushu. Out of Japan this species has been found only on the Chiri-san range in south Korea. This is an interesting discovery for the plant does not grow on Quelpaert Island where so many Japanese species are common, neither has it been found elsewhere in Korea. In the Nikko region $R$. Tschonoskii is quite common, especially round Lake Yumoto, where it grows on shady rocks. On Adzuma-san it is abundant in places fully exposed to the sun and this locality is about the centre of its distribution. On the wind-swept upperslopes of Hayachine-san it is common but north of this mountain I found it to be rare.

The plant forms a broad, densely branched twiggy shrub from 0.3 to $2.5 \mathrm{~m}$. high but is usually from 0.5 to $1.5 \mathrm{~m}$. being taller in the forest shade than on exposed rocks. It prefers rocky ground, but seems to be equally happy in the moist woods of Nikko and on the exposed cliffs and slopes of Adzuma and Hayachine mountains. Sometimes it forms a broad low mat but is more usually an upright shrub. It is always very twiggy and the young shoots are densely covered with closely appressed, flattened rufous hairs. The short stalked leaves are deciduous, crowded at the end of the branches, and vary in shape from narrowlanceolate to ovate-lanceolate or broad-oblanceolate, they are acute and mucronulate and may have one or three prominent nerves; the undersurface is pale and both surfaces have long, appressed, soft, red-brown hairs which are especially noticeable on the young leaves. The flowers are small, with a white corolla, and are four or five partite; they have exserted stamens, and are borne in terminal clusters of from 4 to 6 flowers in each. Except that the leaves vary in size and may have either one or three prominent nerves, and that the flowers are tetramerous or pentamerous the species is very constant. From one and the same bush on Adzuma-san I gathered specimens which exhibited the whole range of variation on which Makino founded his numerous forms. With its small white flowers $R$. Tschonoskii is very distinct from all other Japanese species but as a garden plant it has little to recommend it though in autumn the leaves change to rich shades of orange-red and crimson.

It was discovered in 1865 by Maximowicz's Japanese collector Tschonoski on the mountains of Rikuchu province, northern Hondo, and is figured and described by Maximowicz. It was introduced into England by Charles Maries who sent seeds to Messers Veitch in 1878; to this country it was introduced by Professor Sargent who sent seeds from the Nikko region to the Arnold Arboretum in 1892. 
In $1917 \mathrm{I}$ sent seeds to the same institution from Chiri-san in Korea. The Japanese name for this Azalea is "Shirobana-no Kome-tsutsuji."

Rhododendron microphyton Franchet in Bull. Soc. Bot. France XXXIII. 235 (1886). - Hemsley in Jour. Linn. Soc. XXVI. 28 (1889). - Diels in Notes Bot. Gard. Edinburgh, VII. 309, 392 (Pl. Chin. Forrest.) (1913). - Hutchinson in Millais, Rhodod. 210 (1917).

China: prov. Yunnan, Talang, alt. $1600 \mathrm{~m}$. A. Henry (No. 11,596); Szemao, alt. 1600 m. A. Henry (No. 12,983); "Che-lin-se, Pe-yentsin," May 3, 1916, Siméon Ten (Nos. 86, 86a); "Mt. Lai-chan-po, Pe-yen-tsin," May 2, 1916, Siméon Ten (No.83), "Ni-kou, Pe-yen-tsin," July 5, 1917, Siméon Ten (No. 417); Yunnan Fu, alt. 2000 m. April, 1916, O. Schoch (No. $350 \mathrm{~g}$ ); Tali mountain range, Lat. $25^{\circ} 40^{\prime}$ N. alt. 2600-3300 m. May to July, 1906, G. Forrest (No. 4172).

I have no knowledge of this plant in a wild state but according to notes on the specimens cited above it is an erect, much-branched shrub growing from 0.3 to $2 \mathrm{~m}$. tall. The branchlets are short and twiggy and closely beset with flattened, appressed red-brown bristles. The leaves are persistent, oval to lanceolate in shape, from 0.5 to $3.5 \mathrm{~cm}$. long and from 0.5 to 1.5 broad, acute, obtuse or rounded at the apex which is mucronulate; the upper surface is dark green, the lower pallid and both have scattered hairs on the midrib; the underside and the petioles are clad with red-brown bristles. The flowers are borne several together at the end of the branchlets and in some specimens are so numerous that the stem appears to be clothed with flowers; on others the flower-clusters are sparse. The corolla is rose-colored with crimson markings, with a slender, cylindrical tube from 5 to $8 \mathrm{~mm}$. long and spreading lobes, and varies from 1 to $2 \mathrm{~cm}$. in diameter. The five stamens are exserted and shorter than the style. The calyx is minute or with distinct lanceolate lobes from 1 to $4 \mathrm{~mm}$. long, and like the pedicels and ovary is clothed with straight, shining chestnut-brown hairs. The red-brown pubescence is prominent on this plant. Its small leaves and small flowers resemble those of certain species of the section Lepipherum, rather than those of a species of Tsutsutsi. Where it grows plentifully on open mountain-slopes it must be conspicuous when in bloom, and it would be a desirable addition to gardens even as a pot plant where it would not be hardy. From the altitude given by Forrest (2600-3300 m.) it would appear that this species is not only the most western but the most alpine of the Chinese species of the section. As Franchet points out it is the Chinese analogue of the Japanese $R$. Tschonoskii Maxim. and like that species exhibits considerable variation in size of leaves and flowers. At first I thought Siméon Ten's No. 417 with minute leaves and small flowers was a distinct variety but after careful comparison and dissection I am satisfied that the distinct appearance is the result of exposed ecological conditions.

Rhododendron Seniavinii Maximowicz in Mém. Acad. Sci. St. Pétersbourg, sér. 7, XVI. No. 9, 33, t. 3, fig. 21-24 (Rhodod. As. Or.) (1870). - Hemsley in Jour. Linn. Soc. XXVI. 30 (1889). Bretschneider, Hist. European Bot. Disc. Chin. 620 (1898). - Millais, Rhodod. 240 (1917). 
China: prov. Hunan, Yün-shan, near town of Wukang, alt. 1350$1400 \mathrm{~m}$. June 9, 1918, Dr. Handel-Mazzetti (No. 738).

This rare and very distinct species is unknown to me in a living state. Dr. Handel-Mazzetti says it is a shrub some $2 \mathrm{~m}$. tall, and that it grows on the margins of forests of broad-leafed trees and has white flowers with the tube of the corolla suffused with rose-color and the upper-lobe spotted with purple. The gray and rufous-gray appressed hairs which clothe the shoots, both surfaces of the young leaves, the under-side of adult leaves, pedicels, calyx and ovary well characterise the plant. It is evidently a much-branched twiggy shrub, and the shoots are clad for a season with the usual flattened, appressed bristles of the group. The leaves are persistent or semi-persistent, crowded at the end of the branches, dark green, glabrescent above with impressed reticulate veins. In shape the leaves vary from oval to lanceolate, being from 1.5 to $6.5 \mathrm{~cm}$. long and from 1 to $2.5 \mathrm{~cm}$. wide, acute or obtuse and mucronate at apex. The flowers are small, clustered from 3 to 10 together at the end of the shoots; the corolla is about $1.5 \mathrm{~cm}$. across, with a nearly cylindric tube hairy on the outside, and spreading lobes. The calyx is small and hidden beneath the gray or rufous straight hairs. The five stamens are exserted, and are overtopped by the style, which has a capitate, lobed stigma. In Maximowicz's figure the petioles vary from 0.5 to $1 \mathrm{~cm}$. in length whereas on the specimen cited none exceed $0.5 \mathrm{~cm}$. but this is the only difference $I$ can find and were more material available this would probably disappear.

The discoverer of this species is unknown but from what Bretschneider says it seems probable that the original specimen came from the borders of western Fokien, a region still very little known to us. Dr. Handel-Mazzetti's discovery in southwestern Hunan is an interesting extension of the range of the species, which has for so long remained obscure. It is not in cultivation.

Rhododendron Mariae Hance in Jour. Bot. XX. 230 (1882). Hemsley in Jour. Linn. Soc. XXIX. 27 (1889). - Dunn \& Tutcher in Kew Bull. Misc. Inform. add. ser. X. 155 (Fl. Hongk. and Kwangtung) (1912). - Hutchinson in Millais, Rhodod. 207 (1917).

China: prov. Kwangtung, Ting-woo Mt., May 26, 1918, C. 0. Levine, Canton Christian College Herb. No. 2015 (Herb. Bur. Sci. Manila); Loh-fau-shan, alt. $1000 \mathrm{~m}$. August 10, 1917, C. O. Levine (No. 1563, Herb. Bur. Sci. Manila); same place, August 13, 1917, E. D. Merrill (No. 11,103, Herb. Bur. Sci. Manila); Tiu-kaen-shan, March, 1918, To-Kang-P'eng, Canton Christian College Herb. No. 2370 (Herb. Bur. Sci. Manila).

Known to me only from Hance's description with which the above-cited specimens agree exactly. It is evidently a twiggy shrub and the branchlets are clothed with appressed, reddish gray bristles which, changing to gray persist more or less during a couple of seasons. The leaves are dimorphic, clustered at the end of the branches, persistent and for a plant of its group very coriaceous; they are shining dark green and nearly glabrous above, with impressed, reticulate veins, pale below, with raised veins and scattered appressed rufous bristles. The spring leaves are elliptic-lanceolate from 3 to $9 \mathrm{~cm}$. long and from 2 to $3 \mathrm{~cm}$. wide, acute and mucronulate; the summer leaves are elliptic to obovate from 1 to $3 \mathrm{~cm}$. long and from 0.8 to $1.5 \mathrm{~cm}$. wide, obtuse or rounded at the mucronulate apex. The petioles are 
strigosely pubescent. The flowers are small, crowded in terminal clusters, and fragrant. The corolla is lilac-colored, with a slender tube about $1 \mathrm{~cm}$. long, and small spreading lobes; the 5 exserted stamens are overtopped by the slender style with its capitate stigma. The pedicels are straight from 1 to $1.5 \mathrm{~cm}$. long and with the annular calyx and the ovary are densely clothed with shining, rufous-brown strigose hairs.

This species is known only from one or two localities near Canton in south China and is evidently closely related to $R$. Seniatinii Maxim. So far as I know it has never been introduced into cultivation, although discovered by the Reverend B. C. Henry as long ago as April, 1882.

Rhododendron scabrum G. Don, Gen. Syst. III. 846 (1834). Maximowicz in Mém. Acad. Sci. St. Pétersbourg, sér. 7, XVI. No. 9, 49 (Rhodod. As. Or.) (1870).

Rhododendron sublanceolatum Miquel in Ann. Mus. Lugd.-Bat. II. 163 (186566); Prol. Fl. Jap. 95 (1866-67). - Maximowicz in Mem. Acad. Sci. St. Pétersbourg, sér. 7, XVI. No. 9, 35 (Rhodod. As. Or.) (1870). - Franchet \& Savatier, Enum. Pl. Jap. I. 290 (1875). - Hemsley in Jour. Linn. Soc. XXVI. 31 (1889). - Gard. Chron. XLIX. 342, fig. 157 (1911). - Jour. Hort. Soc. Lond. XXXVII. p. cxxxi. fig. 115 (1911). - Schneider, Ill. Handb. Laubholzk. II. 504 (1911). - Craib in Bot. Mag. CXXXIX. t. 8478 (1913). - Bean, Trees and Shrubs Brit. Isl. II. 381 (1914). - Millais, Rhodod. 249 (1917), - Komatsu in Tokyo Bot. Mag. XXXII. [12] (1918).

Rhododendron indicum Hooker and Arnott, Bot. Voy. Beechey 266 (1841), not Sweet. - Matsumura in Tokyo Bot. Mag. XIV. 69 (1900).

Rhododendron Jodogawa Hort. apud Hasskarl in Cat. Hort. Bog. alt. 162 (1844).

Rhododendron indicum $\beta$. sinensis Miquel in Ann. Mus. Lugd.-Bat. I. 33 (1863-64).

Rhododendron ledifolium $\beta$. purpureum Maximowicx in Mém. Acad. St. Pétersbourg, sér. 7, XVI. No. 9, 36 (Rhodod. As. Or.) (1870), in part.

Azalea sublanceolata O. Kuntze, Rev. Gen. II. 387 (1891).

Rhododendron indicum var. sublanceolatum Makino in Tokyo Bot. Mag. XVIII. 100 (1904). - Matsumura, Ind. Pl. Jap. II. pt. 2, 461 (1912).

Rhododendron sublateritium Komatsu in Tokyo Bot. Mag. XXXII. [12] (1918).

Rhododendron liukiuense Komatsu in Tokyo Bot. Mag. XXXII. [12] (1918).

Liukiu: Okinawa Island, near Katena, sea-level to $100 \mathrm{~m}$. March 8, 1917, E. H. Wilson (No. 8046); without locality, C. Wright (No. 172, Herb. Gray, Herb. Kew): Takuno-shima, hillsides, April 1, 1853, C. Wright (Herb. Gray).

Japan: Kyushu, prov. Satsuma, Kagoshima, cultivated, May 6, 1918, E. H. Wilson (No. 10,344, 10,345); Kajiki, cultivated, May, 1917, Z. Tashiro; prov. Hizen, Nagasaki, 1862, R. Oldham (No. 504, Herb. Gray, Herb. Kew); same locality, G. H. Langsdorff (Herb. Kew); same locality, 1863, C. Maximowicz (Herb. Kew); same locality, cultivated, April 25, 1903, U. Faurie (No. 7873); prov. Chikugo, Kurume, cultivated, May 3, 1918, E. H. Wilson. Hondo, prov. 
Musashi, Yokohama, cultivated, December 22, 1914, E. H. Wilson (No. 7873); same locality, May 15, 1918, E. H. Wilson.

Cultivated: Hort. Holm Lea, Brookline, Mass., April 15, 1915; Hort. Kew, 1912, type of Bot. Mag. t. 8478.

This is a laxly branched shrub from 1 to $2 \mathrm{~m}$. high and has relatively stout branches which are clothed in their first year with appressed, flattened, strigose, graybrown hairs which gradually disappear. The leaves areshining, coriaceous, nearly glabrous except on the veins at maturity, persistent; those formed in the spring are lanceolate to elliptic-lanceolate, from 4 to $10 \mathrm{~cm}$. long and from 2 to $3.5 \mathrm{~cm}$. broad, acute or obtuse and mucronate at the apex, the base broadly cuneate, the margin slightly recurved ciliate and sub-crenulate, the principal veins impressed above and prominently raised on the under surface; the summer leaves are oblanceolate, smaller and more coriaceous than the spring leaves and subacute or rounded at the apex, which is mucronulate; when young the leaves have appressed, straight gray-brown hairs more especially on the nerves and an occasional sessile gland on the under-side; at maturity they are very sparsely pubescent except on primary and secondary nerves; the petiole is stout, flattened, somewhat appressed to the shoot, and is clothed with pubescence similar to that on the shoots and leaf veins. The winter-buds are ovoid, acute, clothed with mufous, appressed straight hairs; the inner bud-scales cinnamon-brown, ciliate, viscid on inner surface and remain on the base of the pedicels of the expanded flowers. The flowers are borne in terminal clusters from 2 to 6 in each. The calyx is green, ample, the lobes usually oval and rounded, about $6 \mathrm{~mm}$. long and $5 \mathrm{~mm}$. broad, sometimes one and occasionally all the calyx-lobes lance-shape and $1.2 \mathrm{~cm}$. or more long, acuminate, ciliate and glandular, and covered with appressed, straight, gray hairs. The corolla is rose-red to vivid scarlet, broad-funnel-shape about $6 \mathrm{~cm}$. wide, lobed nearly to the middle; stamens 10, included, overtopped by style. The fruit is erect, ovoid, from 1 to $1.2 \mathrm{~cm}$. long, sparsely hairy, and is subtended by persistent calyx-lobes.

This species is endemic in the Liukiu Islands, where it is confined to the middle, or Okinawa, group of islands and to Takuno-shima, the most southern of the northern, or Oshima, group. It grows among shrubs, coarse grasses and Pinus luchuensis Mayr, and when in bloom is very conspicuous. It is a common plant in gardens round Kagoshima in south Japan, having been long ago introduced from Liukiu. From Kagoshima it has been taken to Nagasaki and north as far as Tokyo, but it is only in the warmer parts of south Japan that it can be described as a comman garden plant. The leaves, flowers and fruit are larger than those of other species of the group; the leaves are also more persistent and more coriaceous. The flowers are normally of an intense scarlet but they vary to rose-red. The calyx-lobes are often very unequal in size on the same flower or flower-cluster and they vary too in degree of pubescence. In habit it is more vigorous but less compact than that of other species of the group. Specimens in Herb. Kew and Herb. Gray labelled R. Sieboldii var. ellipticum ex Herb. Lugd.-Bat., 1863, would appear to belong here though the flowers are abnormally small for the species. The leaves, bud-scales, calyx and number of stamens agree and it may be that the specimens are from a plant flowering out of season or under abnormal conditions.

Maximowicz, Miquel and Makino refer to it as the "Chinese Azalea" but there does not appear to be any authority for the statement since the plant itself is unknown in China. To-day in Japan generally it is known as the Liukiu (Riukiu) Azalea, but round Kurume in Kyushu it is called "Hiwoge-yodogawa." Maximowicz does not appear to have properly known this species and has confused Wright's Tokuno-shima specimen and others with his $R$. ledifolium $\beta$. purpureum yet he 
states that it was introduced into Petrograd in 1864. In England this Liukiu species doee not appear to have been properly known before 1911, when Mr. R. C. Notcutt of Woodbridge exhibited it at the Royal Horticultural Society's Temple Show in London. In 1915 I brought plants from Japan to the Arnold Arboretum. Of all the red-flowered species of eastern Asia except the Formosan R. Oldhamii Maxim. it is the least hardy. In Massachusetts it is a greenhouse plant and blossoms sparsely. Miquel did not know the color of the flowers of his $R$. sublanceolatum citing it as alba? which it certainly is not for no white form is known even to-day. The color of the flowers varies from intense scarlet to rich magenta. Don gives deep rose-color for the type and the scarlet-flowered form, which is the usual form found growing wild, may be distinguished as f. coccineum Wilson, $\mathbf{n}$. name. It is unfortunate that we have to adopt Don's name for this species yet it is undoubtedly the oldest since his description fits this plant and no other. He says that the leaves are "ovate" a term not of ten applicable to the leaves of any Azalea, they are, however, broader in this species than in any other. Don cites as a synonym $R$. maximum Thunb., which is $R$. Metternichii S. \& Z., but no word of his description has reference to this Eurhododendron. This Liukiu species has been cultivated round Nagasaki and other towns in southern Kyushu I know not how long, but Don is wrong in saying that it is native of Japan, though the mistake is natural when the period he wrote in is considered. Komatsu bases his two specieg on slight differences in the shape of the leaves, in the color of the corolla and on the length of the corolla-tube. Such trivial differences are unimportant in such variable plants as the Azaleas of the Tsutsutsi section.

\section{Rhododendron phoeniceum G. Don, Gen. Syst. III. 846 (1834).}

Azalea indica var. $\gamma$. Sims in Bot. Mag. LIII. t. 2667 (1826).

Azalea punicea Sweet apud Poiteau in Annal. de From. I. 102, 104 (1829), not Rhododendron indicum a. puniceum Sweet.

Rhododendron indicum $\gamma$. phoeniceum Sweet, Brit. Flow. Gard. ser. 2, II. sub. t. 128 (1832).

Rhododendron indicum var. speciosum D. Don in Sweet, Bril. Flow. Gard. ser. 2, III. t. 284 (1835), excluding synonomy.

Azalea indica phoenicea Hovey, Am. Gard. Mag. I. 224 (1835).

Azalea indica Rawsonii Loudon, Gard. Mag. n. ser. II. 421 (1836).

Azalea Rawsonii Paxton, Mag. Bot. III. 123, t. (1837).

Rhododendron indicum $\gamma$. purpureum De Candolle, Prodr. VII. pt. 2, 726 (1839), in part, not Sweet.

Rhododendron ledifotium $\beta$. phoeniceum De Candolle, Prodr. VII. pt. 2, 727 (1839), in part. - Rehder in Bailey, Stand. Cycl. Hort. V. 2944 (1916).

Rhododendron puniceum Planchon in Fl. des Serr. IX. 79 (1854), not Roxburgh; in Rev. Hort. 1854, 46, 61. - Maximowicz in Mém. Acad. Sci. St. Pétersbourg, sér. 7, XVI. No. 9, 35 (Rhodod. As. Or.) (1870). - Schneider, Ill. Handb. Laubholzk. II. 504 (1911).

Azalea phoenicea Hort. Paris apud Planchon in Fl. des Serr. IX. 79 (1854), as a synonym; in Rev. Hort. 1854, 61.

Japan: ex Siebold comm. Zuccarini ex Herb. Zucc. 1842 (Herb. Gray, doubtful specimen).

Cultivated: Hort. Holm Lea, March 30, 1917, A. Rehder.

Although introduced into European gardens as long ago as 1824 and used in such vast quantities as a stock on which to graft the varieties of "Indian Azaleas" 
so-called, the origin of this plant is obscure. It appears to have been sent from Canton, China, to the Horticultural Society's garden at Chiswick, probably by John Reeves but the facts are not clearly known. One of these plants was figured by Sims in the Botanical Magazine (t. 2667), and according to Poiteau it was known in the gardens round Paris in 1829 but was rare. No wild species to which it can be referred unhesitatingly has been discovered. In Japan I saw nothing just like it but it is evident that the "Omurasaki-tsutsuji " is a glorified form of it. In its vigorous habit, size of flower and shyness of blossoming $R$. phoeniceum G. Don resembles $R$. scabrum G. Don, whilst in the calyx and character of pubescence it suggests $R$. mucronatum G. Don; its viscid inner bud-scales agree with both species. Possibly it is a hybrid between these two species though $I$ incline to the belief that it is nothing but an extreme form of $R$. scabrum $\mathrm{G}$. Don. I have not been able to discover just when it reached America but it was eultivated by Hovey \& Co., Boston, Mass., in 1835. In England attemps to hybridise this plant with all sorts of species of Rhododendron were made and the books record a number of presumed hybrids of remarkable parentage. For example Paxton's Azalea Rawsonii is said to be a cross between $A$. phoenicea and $R$. dauricum atrovirens but an unbiased examination of the plate reflects nothing but a good colored form of $R$. phoeniceum. Other presumed hybrids are dealt with hereunder and it is evident that enthusiasm out-did the facts. It is probable that this plant has had something to do in the evolution of the present-day race of "Indian Azaleas." In Belgium $R$. phoeniceum and its variety concinnum are the principal stocks used in grafting the "Indian Azaleas" of commerce.

\section{A form of this is: -}

\section{Rhododendron phoeniceum $\mathrm{f}$. semiduplex Wilson, $\mathrm{n}$. $\mathrm{f}$.}

Azalea ledifolia var. $\beta$. phoenicea Hooker in Bot. Mag. LX. t. 3239 (1833).

Rhododendron ledifolium $\beta$. phoeniceum De Candolle, Prodr. VII. pt. 2, 727 (1839), in part.

G. Don and others have merged this into the type but its semi-double flowers make it distinct as a garden plant. The color is poor. I have seen the specimen preserved in Herb. Kew from which the Botanical Magazine figure was prepared but no living material, and do not know if the plant is now in cultivation. In the typical $R$. phoeniceum flowers are of ten seen in which the stamens show a tendency toward becoming petaloid.

\section{Another form is: -}

\section{Rhododendron phoeniceum f. Smithii Wilson, n. comb.}

Rhododendron indicum $\gamma$. Smithii Sweet, Hort. Brit. ed. 2, 343 (1830).

Rhododendron pulchrum Sweet, Brit. Flow. Gard. ser. 2, II. t. 117 (1832),De Candolle, Prodr. VII. pt. 2, 726 (1839). - Maximowicz in Mem. Acad. Sci. St. Pétersbourg, sér. 7, XVI. No. 9, 36 (Rhodod. As. Or.) (1870).

Rhododendron indicum pulchrum G. Don, Gen. Syst. III. 845 (1834).

Azalea indica hybrida Loudon, Gard. Mag. n. ser. I. 326 (1835). - Hovey, Am. Gard. Mag. II. 157 (1836).

This plant is stated variously to be " the produce of $R$. ledifolium Hook. impregnated by the pollen of the Old Red $R$. indicum," and " a hybrid between $R$. phoeniceum and $R$. ledifolium" but to me it appears to be nothing else than a form of $\boldsymbol{R}$. phoeniceum. Under Loudon's name it was introduced into America about 1835 and was exhibited for the first time before the Massachusetts Horticultural Society on March 5, 1836, by Hovey \& Co. For many years it was a favorite 
plant at exhibitions. It is still cultivated in the Magnolia Gardens, near Charleston, South Carolina.

An old and obscure plant is:-

Rhododendron phoeniceum f. splendens Wilson, n. comb.

Rhododendron phoeniceum var. splendens D. Don in Sweet, Brit. Flow. Gard. ser. 2, IV. t. 385 (1837).

This is said to be a seedling raised from $R$. phoeniceum G. Don pollinated by $R$. catawbiense Mich. but the figure shows no influence of the latter plant. That it is a seedling may be accepted, but it is certainly nothing more than a good colored form of $R$. phoeniceum with only from 5 to 8 stamens.

A common garden plant in Japan is: -

Rhododendron phoeniceum var. calycinum Wilson, n. comb.

Azalea indica calycina Lindley in Paxton, Flow. Gard. II. 169, t. 70 (1852).

Rhododendron calycinum Planchon in Fl. des Serr. IX. 81 (1854); in Rev. Hort. $1854,65$.

Rhododendron ledifolium $\beta$. purpureum Maximowicz in Mém. Acad. Sci. St. Pétersbourg, sér. 7, XVI. No. 9, 36 (Rhodod. As. Or.) (1870), in part. Franchet \& Savatier, Enum. Pl. Jap. I. 291 (1875). - Matsumura, Ind. Pl. Jap. II. pt. 2, 462 (1912). - Rehder in Bailey, Stand. Cycl. Hort. V. 2944 (1916).

Azalea rosmarinifolia var. purpurea Rehder in Bailey, Cycl. Am. Hort. I. 123 (1900).

Rhododendron rosmarinifolium var. purpureum Schneider, Ill. Handb. Laubholzk. II. 504 (1911). - Komatsu in Tokyo Bot. Mag. XXXII. [35] (1918).

Rhododendron rosmarinifolium var. speciosum Makino in Tokyo Bot. Mag. XXVII. 110 (1913).

Rhododendron Oomurasaki Makino in Jour. Jap. Bot. I. 18 (1917).

Rhododendron Osakazuki Komatsu in Tokyo Bot. Mag. XXXII. [46] (1918); in Icon. Koisikav. IV. 9, t. 217 (1918).

Japan: Kyushu, prov. Hizen, Nagasaki, cultivated, 1863, C. Maximowicz (Herb. Kew, Herb. Gray, co-types of $R$. ledifolium B. purpureum Maxim.); same locality, 1862, R. Oldham (No. 509, Herb. Kew, Herb. Gray; No. 607, Herb. Kew); prov. Chikugo, Kurume, cultivated, May 3, 1918, E. H. Wilson. Hondo, prov. Choshu, Shimonoseki, Sanyo Hotel garden, cultivated, May 17, 1917, E. H. Wilson (No. 8425); prov. Musashi, Yokohama, cultivated, Hort. Suzuki, May 15, 1918, E. H. Wilson; Tokyo, cultivated, May 11, 1902, K. Sakurai; same locality, cultivated, May 12, 1910.

As pointed out by Lindley this variety is much superior to the type for it has larger, more richly colored flowers. The corolla is rose-purple with crimson spots. The calyx-lobes are larger and more acuminate but they vary. In Paxton's figure the calyx is glabrous but this is a mistake. It is ciliate and sparsely or densely clothed with long, straight, appressed hairs. Apart from the calyx Paxton's figure is an excellent representation of the Omurasaki-tsutsuji (large purple Azalea) so much grown in the gardens of Yokohama, Tokyo and elsewhere in Japan. At 
Kurume in Kyushu it is known as the Kumagai-yodogawa. It is a vigorous freeflowering plant of compact habit of growth, and its large, magenta-red flowers are very handsome. Nothing definite appears to be known in Japan of the origin of this Azalea but it has been cultivated for a long period. Maximowicz's specimen undoubtedly belongs here, but those of Langsdorf, Wright and some of Oldham's included by Maximowicz under his var. purpureum belong to $R$. scabrum G. Don. Recent botanists seem to have overlooked Lindley's name and excellent figure. According to Planchon this variety was introduced from China by Robert Fortune to the gardens of the Horticultural Society at Chiswick where it flowered for the first time in 1851.

A very hardy form with carmine-red flowers much cultivated in Europe and, to a less degree, in this country may be distinguished as:-

Rhododendron phoeniceum var. calycinum f. Maxwellii Wilson, n. comb.

Azalea Maxwelli Hort. Wezelenburg, Cat. 6, fig. (1915).

Rhododendron Maxwelli Millais, Rhodod.208, fig. (1917).

Japan: Kyushu, prov. Chikugo, Kurume, cultivated, May 3, 1918, E. H. Wilson.

Cultivated : Hort. Bobbink \& Atkins, Rutherford, N. J., April, 1920.

At Kurume this bright-colored form is known as the "Aka-yodogawa."

To this variable species must be added:-

Rhododendron phoeniceum var. tebotan Wilson, n. comb.

Rhododendron Tebotan (Rh. Kaempferi $\times$ Rh. rosmarinifolium) Komatsu in Tokyo Bot. Mag. XXXII. [46] (1918).

This variety has double flowers with small green leaves showing the centre, and is remarkable for its color which is the same as that of Bougainvillaea glabra Choisy, and quite unique among Azaleas. It is an old plant in Japanese gardens but is now rare and Japanese nurserymen substitute for it Azalea "Fuji-manyo" (R. mucronatum f. plenum Wils.). In 1919 I secured in Japan a living plant of the true var. tebotan for the Holm Lea collection where it has flowered.

Rhododendron yedoense Maximowicz apud Regel in Gartenfl. XXXV. 565, t. 1233 a-b (1886). - Millais, Rhodod. 264 (1917).

Azalea Yodogava Grignan in Rev. Hort. 1908, 425 t. fig. 2.

Rhododendron phoeniceum Matsumura, Ind. Pl. Jap. II. pt. 2, 463 (1912), not G. Don.

Rhododendron Yodogawa Kunert in Gartenwelt XVI. 163, t. (1912). - Millais, Rhodod. 264 (1917).

Rhododendron poukhanense var. yodogawa Rehder in Mitt. Deutsch. Dendr. Ges. XXIV. 225 (1916); in Bailey, Stand. Cycl. Hort. V. 2943 (1916).

Rhododendron Poukhanense var. plenum Nakai in Tokyo Bot. Mag. XXXI. 245 (1917). - Komatsu in Tokyo Bot. Mag. XXXII. [12] (1918).

Azalea Tado Guno Hort. apud Millais, Rhodod. 264 (1917), as a synonym.

Rhododendron Matsumurai Komatsu in Tokyo Bot. Mag. XXXII. [13] (1918). 
Korea: prov. Keiki, cultivated, Forestry Experimental Garden, Keijyo, May 21, 1917, E. H. Wilson (No. 8422).

Cultivated: Arnold Arboretum (No. 7345); ex Hort. E. G. Loder, May, 1898 (Herb. Kew).

This double-flowered Azalea, in recent years exported from Japan in some quantity to the gardens of Europe and America, is certainly nothing but a monstrous form of $R$. yêdoënse var. poukhanense Nakai. My Korean specimens came from a plant which had been found wild not far from Mt. Poukhan and transplanted to the Government Forestry Experimental Garden, and are indistinguishable from others taken from plants cultivated in the Arnold Arboretum. The habit is spreading and more lax than in the type except when the latter grows among tall bushes. The flowers are quite double, and the corolla is rose-purple and much less beautiful than that of the type; the calyx is green, often larger than in the type, with oval segments. The leaves are characteristic and have the impressed veins on the upper surface.

This form seems to have become known in our gardens comparatively recently and to have been first introduced into Petrograd by Japanese and exhibited at the International Exhibition there in 1884. It is perfectly hardy in the Arnold Arboretum. Matsumura gives "Botan-tsutsuji" (Paeony Azalea) as the vernacular name of this plant.

The wild type of the species is:-

Rhododendron yedoense var. poukhanense Nakai in Tokyo Bot. Mag. XXXIV. (274) (1920).

Rhododendron indicum var. Simsii Palibin in Act. Hort. Petrop. XVIIr. 150 (Consp. Fl. Kor. 11, 4) (1900), not Maximowicz. - Nakai in Jour. Coll. Sci. Tokyo, XXXI. 76 (Fl. Kor. II) (1908).

Rhododendron poukhanense Léveille in Fedde, Rep. Nov. Sp. V. 100 (1908).Nakai in Journ. Coll. Sci. Tokyo, XXXI. 76 (Fl. Kor. II) (1908); in Tokyo Bot. Mag. XXXI. 244 (1917); Fl. Syl. Kor. VIII. 47, t. 18 (1919). - Komatsu in Icon. Pl. Koisikav. II. 97, t. 133 (1915). - Rehder in Mitt. Deutsch. Dendr. Ges. XXIV. 225 (1916); in Bailey, Stand. Cycl. Hort. V. 2943 (1916).

Rhododendron hallaisanense Léveillé in Fedde, Rep. Nov. Sp. XII. 101 (1913). Rhododendron coreanum Rehder in Mitt. Deutsch. Dendr. Ges. XXII. 259 (1913). - Millais, Rhodod. 148 (1917).

Korea: Quelpaert Island, sea-level to $1600 \mathrm{~m}$. abundant, October 29, November 6, 1917, E. H. Wilson (Nos. 9396, 9458); same locality April 14, October 25, 1908, June 1909, E. Taquet (Nos. 1090, 1091, 4679, 4680, 2972); prov. South Keisho, Fusan, May 18, 1906, U. Faurie (No. 670); prov. Keiki, Kazan, near Suigen in Pine-woods, May 24, 1917, E. H. Wilson (No. 8472); Seoul, April 29, 1894, Miss A. Sontag (Herb. Kew); same place, Mt. Poukhan, September 25, 1905, J. G. Jack; province unknown, "Mt. Pomasa," May 21, 1906, U. Faurie (No. 664).

Cultivated: Arnold Arboretum (No. 7254). 
This Korean Azalea is usually a compact densely branched shrub from a few inchis: to a metre high, but in shaded places it may be as much as two metres tall and rather loosely branched; on wind-swept slopes and on the tops of rocks it hugs the ground and forms broad mats. The branches are twiggy and clothed with appressed gray hairs which disappear the second year. No part of the plant is glandular; the winter-buds are ovoid, more or less pointed and covered with appressed, gray-brown hairs. The leaves are quite or partially deciduous according to climate and in the autumn are tinted from orange to crimson. The spring leaves are membranous, oblanceolate to lanceolate or ovate-lanceolate, from 3 to $8 \mathrm{~cm}$. long and from 1 to $2 \mathrm{~cm}$. broad, acute and mucronate at apex, with a narrow wedge-shaped base; they are dark green and have impressed veins on the upper surface, and are pallid below where the principal veins are prominent, ascending and arching inward but not extending to the margins of the leaf; both surfaces are clothed with straight appressed gray to shining brown hairs. The summer leaves are thicker, narrowly oblong-lanceolate, from 0.4 to $1 \mathrm{~cm}$. wide, attenuate at the base; the margins are often obscurely crenate-serrate, and the upper surface is glabrous at maturity except for a few, short appressed, white bristles. The flowers are in clusters of two to several, and are remarkably fragrant, with s corolla rose to rosy purple. The calyx is ample, green and clothed with pubescence similar to that of the leaves, the lobes are lanceolate to ovate-lanceolate, from 5 to $10 \mathrm{~mm}$. long, acute, obtuse or rounded. The pistil is exserted but the stamens are included, 10 in number, with purple anthers. The fruit is erect, ovoid, from 7 to $10 \mathrm{~mm}$. long, clothed with strigose hairs and subtended by the persistent calyx-lobes. This is the common Azalea of Korea from about the latitude of Seoul (Keijyo), the capital city southward. It is partial to open country and on grassy mountain-slopes and in thin Pine-woods it forms dense matlike masses from a few inches to a yard high. On boulders in water-courses the growth is low and dense but in thickets the plants are more loosely branched and often two metres high. It grows from sea-level up to about $1600 \mathrm{~m}$. altitude according to latitude and in some places, like the foothills of Chiri-san, it is very abundant. On Quelpaert it grows from sea-level to near the summit of Hallai-san and is common on boulders in the water-courses and on the moorlands. On Poukhansan behind Keijyo from which it derives its specific name it is rare though there are places not far from there where it is common.

This Azalea was introduced to the Arnold Arboretum by Mr. J. G. Jack who sent seeds from Poukhan-san in the autumn of 1905. Plants flowered for the first time in May, 1914. It has proved perfectly hardy here, grows freely and flowers profusely. The flowers are distinctly and plessantly fragrant and the plant is a decided acquisition to the list of hardy species of its section.

Japanese botanists have recorded this plant from several places in Hondo, Japan, and Komatsu (in Tokyo Bot. Mag. XXXII. [38] (1918)) enumerates fourteen garden forms. I have seen the Japanese material from wild plants referred to this species in the herbarium of the Imperial Botanic Garden, Tokyo, but it is too fragmentary to base a definite opinion upon. That from the Tokyo region has yellow anthers and belongs to $R$. obtusum var. Kaempferi f. mikawanum Wils. It certainly has nothing to do with $R$. yêdoënse var. poukhanense. That from Bitchu province collected by $\mathrm{Z}$. Yoshino has purple anthers and the veins on the upper surface are indistinctly impressed. It may represent Nakai's variety but the material is too incomplete to judge by.

Rhododendron Oldhamii Maximowicz in Mém. Acad. Sci. St. Pétersbourg, sér. 7, XVI. No. 9, 34 (Rhodod. As. Or.) (1870). - Masters in Gard. Chron. n. ser. XVII. 524 (1882). - Hemsley in Jour. Linn. Soc. 
XXVI. 28 (1889). - Henry in Trans. Asiat. Soc. Jap. XXIV. suppl. 57 (1896). - J. H. Veitch, Hortus Veitchii, 286 (1906). - Matsumura \& Hayata in Jour. Coll. Sci. Tokyo, XXII. 218 (Enum. Pl. Formos.) (1906). - Hayata in Jour. Coll. Sci. Tokyo, XXV. art. 19, 153 (Fl. Mont. Formos.) (1908). - Matsumura, Ind. Pl. Jap. II. pt. 2, 463 (1912). - Komatsu in Icon. Pl. Koisikav. II. 69, t. 119 (1914); in Tokyo Bot. Mag. XXXII. [11] (1918). - Kanehira, Formos. Trees, 325, fig. 10 (1917). - Millais, Rhodod. 220 (1917).

Azalea Oldhamii Hort. Veitch. apud Masters in Gard. Chron. n. ser. XVII. 524 (1882).

Rhododendron Oldhamii var. glandulosum Hayata in Jour. Coll. Sci. Tokyo XXV. art. 19, 153 (Fl. Mont. Formos.) (1908).

Rhododendron longiperulatum Hayata, Icon. Pl. Formos. III. 138 (1913).Kanehira, Formos. Trees, 323, fig. 13 (1917). - Komatsu in Tokyo Bot. Mag. XXXII. [14] (1918).

Formosa: prov. Taihoku, Jyukirin, sea-level to $1000 \mathrm{~m}$., April 8, 1918, E. H. Wilson (No. 10,316); Tamsui, 1864, R. Oldham (No. 212, Herb. Kew, Herb. Gray); Sekitei, alt. 100-500 m. March 17, 1918, E. H. Wilson (No. 10,165); prov. Nanto, round Lake Candidius, March 11, December 7, 1918, E. H. Wilson (Nos. 9980, 11,175); beyond Musha up to $2900 \mathrm{~m}$. March 3, 1918, E. H.Wilson (No. 10,029); prov. Kagi, beyond Ari-san, alt. 2800-2900 m. February 4, 1918, E. H. Wilson (No. 9778); prov. Koshun, South Cape, Schmüser ex A. Henry (Nos. 588, in part, 588A. Herb. Kew); prov. unknown, "Okasaki," March, 1914, U. Faurie (No. 164, Herb. Bur. Sci. Manila); without locality ex Herb. Imp. Bot. Gard. Tokyo (Herb. Bur. Sci. Manila).

This is the cornmon red-flowered Azalea of Formosa, where it is endemic and widely spread from sea-level up to $2800 \mathrm{~m}$. altitude but is more abundant in the north than elsewhere. On volcanic Mt. Daiton, not far from the capital city of Taihoku, it is a feature on the wind-swept upper slopes. On sandstone cliffs east of Taihoku it is common, and in thickets round Lake Candidius in central Formosa it is a conspicuous shrub. On the grass-clad highlands beyond Musha and beyond Ari-san it is plentiful. I did not see it in the extreme south, which is of coral formation, and suspect that Schmüser's specimen cited really came from the savage territory more to the north. The species is very glandular and very hairy, the leaves shoots, pedicels and calyx being covered with a soft pubescence much of which is long, villose and ferrugineous in color but on wind-swept mountains in winter the pubescence may be bleached pale gray and the plant shaggy in appearance. It is a much-branched shrub from 1 to $3 \mathrm{~m}$. tall, bushy in habit with twiggy branchlets densely clothed with glandular, spreading, red-brown hairs among which are scattered flattened, paleaceous hairs spreading and less appressed than is the rule in other red-flowered Azaleas. The leaves are persistent, and vary in shape from elliptic or elliptic-oblong to elliptic-ovate or very rarely to lanceolate; they are from 2 to $8 \mathrm{~cm}$. long and from 1 to $4 \mathrm{~cm}$. wide, rounded or subacute at the 
apex which is furnished with a long gland-tipped mucro; the base is narrowed. Both surfaces and the petiole are clothed with pubescence similar to that on the shoots; on mature leaves the upper surface is scaberulous from the presence of the tumid persistent base of deciduous hairs; the veins are impressed above, raised and prominently reticulate below. The flowers are borne at the end of the shoots, and at low altitudes appear every month in the year. The corolla is red, funnel-shape, with spreading, rounded lobes, and from 3 to $5 \mathrm{~cm}$. in diameter. The calyx is green and variable in size, and the lobes may be rounded and less than $1 \mathrm{~mm}$. long or triangular-acuminate and as much as $8 \mathrm{~mm}$. long. The ten stamens are of unequal length, the longest almost equalling the corolla but overtopped by the slender, glabrous, exserted style. The fruit is more or less erect, ovoid, from 6 to $10 \mathrm{~mm}$. long, densely glandular-setose, on pedicels from 1 to $1.5 \mathrm{~cm}$. long.

This species varies considerably in size of the leaves and calyx-lobes and somewhat in degree of hairiness and glandulosity but is well marked and easily recognized among all the species of its section. At its altitudinal limits and on bleak mountain-slopes the leaves, which are scattered on the free shoots and clustered at the end of the branchlets, are tinted blackish purple. It was discovered by Richard Oldham round Tamsui in 1864, and introduced to gardens by Charles Maries who sent seeds to Messers Veitch in 1878. Plants raised from these seeds were exhibited in London in the spring of 1882. Whether plants of this origin are still in cultivation I do not know. In 1918 I sent seeds to the Arnold Arboretum which were distributed in America and Europe. As a greenhouse plant Oldham's Azalea is worth cultivating.

In Tokyo I examined the type specimen of $R$. longiperulatum Hayata and could find no characters by which to separate it from $R$. Oldhamii. On Mt. Daiton, the type locality given by Hayata for his species, the variable $R$. Oldhamii is abundant but I could find no other species of the group growing there. Mr. Shimada who accompanied me told me it was all $R$. longiperulatum Hayata so-named from his original specimen collected on this mountain.

Rhododendron mucronatum G. Don, Gen. Syst. III. 846 (1834).

Azalea rosmarinifolia Burmann, $F$ l. Ind. 43, t. 3 , fig. 3 (1768). - Rehder in Bailey, Cycl. Am. Hort. I. 123 (1900).

Azalea mucronata Blume, Cat. Gewass. Buitenz. 44 (1823); Bijdr. Fl. Nederl. 853 (1825).

Azalea indica alba Lindley, Bot. Reg. X. t. 811 (1824), - Loddiges, Bot. Cab. XIII. t. 1253 (1827).

Azalea ledifolia Hooker in Bot. Mag. LVI. t. 2901 (1829). - Hovey, Mag. Hort. IV. 135 (1838).

Azalea liliiflora Poiteau in Annal. de From. 104 (1829). - Loiseleur, Herb. A mat. sér. 2, I. t. 40 (1839). - Carrière in Rev. Hort. 1869, 299.

Azalea alba Sweet apud Poiteau in Annal. de From. 104 (1829), as a synonym.

Rhododendron leucanthum Bunge in Mém. Soc. Etr. Acad. Sci. St. Pétersbourg, II. 115 (Enum. Pl. Chin. Bor. 41) (1833).

Rhododendron ledifolium G. Don, Gen. Syst. 846 (1834). - Siebold and Zuccarini in Abh. Akad. Münch. IV. pt. III. 131 (Fl. Jap. Fam. Nat. II. 7) (1846). - Planchon in Rev. Hort. 1854, 48. - Boissier, Herb. Boiss. V. 918 (1897). - Bean, Trees and Shrubs Brit. Isl. II. 365 (1914). - Rehder in Bailey, Stand. Cycl. Hort. V. 2943 (1916). - Millais, Rhodod. 201, t. (1917).

Rhododendron Burmanni G. Don, Gen. Syst. III. 846 (1834).

Rhododendron macranthum var. albiflorum Souchetianum Lemaire in Loiseleur, Herb. Amat. sér. 2, III. t. 15 (1843). 
Rhododendron liliiflorum grandiflorum souchetianum Lemaire in Loiseleur, Herb. Amat. sér. 2, III. sub. t. 15 (1843), as a synonym.

Rhododendron ledifolium a. leucanthum De Candolle, Prodr. VII. pt. 2, 727 (1839). - Miquel in Ann. Mus. Lugd.-Bat. I. 34 (1863); II. 164 (1865-66); Prol. Fl. Jap. 96 (1866-67). - Maximowicz in Mém. Acad. Sci. St. Pétersbourg, sér. 7, XVI. No. 9, 36 (Rhodod. As. Or.) (1870). - Franchet \& Savatier, Enum. Pl. Jap. I. 291 (1875). - Matsumura, Ind. Pl. Jap. II. pt. 2, 462 (1912).

Rhododendron rosmarinifolium Dippel, Handb. Laubholzk. I. 421 (1889), not Vidal. - Voigtländer in Gartenwelt XV.650, fig. (1911). - Schneider Ill. Handb. Laubholzk. II. 503, figs. $330 \mathrm{f} ., 331 \mathrm{c}-\mathrm{e}$ (1911). - Komatsu in Tokyo Bot. Mag. XXXII. [13] (1918).

Azalea rosmarinifolia var. alba Rehder in Bailey, Cycl. Am. Hort. I. 123 (1900). Rhododendron rosmarinifolium var. album Schneider, Ill. Handb. Laubholzk. II. 504 (1911).

Rhododendron ledifolium var. album Rehder in Mitt. Deutsch Dendr. Ges. XXIV. 225 (1916).

Japan : Kyushu, prov. Hizen, Nagasaki, cultivated, April 25, 1903, U. Faurie (No. 5434); prov. Chikugo, Kurume, cultivated, May 3, 1918, E. H. Wilson. Hondo, prov. Choshu, Shimonoseki, cultivated, garden Sanyo Hotel, May 17, 1917, E. H. Wilson (No. 8426); prov. Settsu, near Osaka, cultivated, May 7, 1918, E. H. Wilson; prov. Kishu, May 15, 1911, K. Sakurai; prov. Musashi, Yokohama, cultivated, 1862, C. Maximowicz (Herb. Kew); Tokyo, cultivated, March 29, 1914, E. H. Wilson (No.6339); same locality, cultivated, May 15, 1882, K. Miyabe; prov. Ugo, Akita, cultivated, May 20, 1888, $U$. Faurie (No. 2133); prov. Mutsu, Hirosaki, May 27, 1905, U. Faurie (No. 6786). Hokkaido, prov. Oshima, Hakodate, cultivated, 1855, C. Wright (Herb. Gray, Herb. Kew); same locality, 1862, $M$. Albrecht (Herb. Kew).

Japan: without locality, 1862-63, R. Oldham (No. 506); ex Herb. Lugd.-Bat., 1863 (Herb. Gray, Herb. Kew).

China: prov. Hupeh, Ichang, cultivated, A. Henry (No. 3503, Herb. Gray).

Cultivated : ex Herb. Bot. Bog. (Herb. Bur. Sci. Manila); Forest Hills Cemetery, Boston, Mass., June 9, 1906, J. G. Jack; Butler Plantation, West Feliciana Parish, La., March 28, 1910, C. S. Sargent; Hort. Berckmans, Augusta, Georgia, March 18, 1909, C. S. Sargent; Hort. Kew, May 28, 1901, A. Rehder.

This well-known plant is a much-branched compact, wide-spreading shrub usually from 1.5 to $2 \mathrm{~m}$. tall but sometimes over $3 \mathrm{~m}$. high and more in diameter. The shoots in their first year, as well as the petioles and pedicels, are densely clothed with gray to gray-brown, spreading, soft hairs and intermixed with them, especially on the shoots, are few or many appressed and spreading, flattened, bristle-like hairs. On both shoots and pedicels occasional glandular hairs are present; the inner 
acales of the flower-buds are also glandular. The spring leaves are light green, deciduous and rather thin in texture, they are lanceolate to ovate-lanceolate, from 3 to $6 \mathrm{~cm}$. long and from 1 to $2.5 \mathrm{~cm}$. wide, acute or obtuse, mucronulate, clothed on both surfaces with soft, straight, appressed, gray to rufous hairs; the summer leaves are dark green, numerous, persistent and sub-coriaceous, oblong-lanceolate to oblanceolate-oblong, from 1 to $4 \mathrm{~cm}$. long and from 0.6 to $1.2 \mathrm{~cm}$. wide, obtuse or rounded, mucronate, somewhat rugulose above, prominently veined on the lower surface, their margins more or less recurved; both surfaces are clothed with soft, straight, appressed, gray to rufous hairs, and of ten mixed with these are spreading, glandular, gray hairs. The flowers are in clusters of one or more at the end of the branch, fragrant, pure white; occasionally an odd branch may have rose-colored flowers, or flowers striped with rose. The calyx is green and ample, the calyx-lobes are erect, lance-shaped, about $1 \mathrm{~cm}$. long, often somewhat erose and more or less densely glandular-pubescent. The corolla is wide-funnel shape from 4 to $5 \mathrm{~cm}$. long and broad; the stamens are usually 10 (occasionally 8 ) as long as the corolla or nearly so, and are exceeded by the pistil which is slightly exserted. The fruit is conic, with appressed setose hairs, and is shorter than the persistent calyx-lobes which surround it.

This Azalea is a favorite plant in Japan and has a place in almost every garden more especially from Tokyo southward, but its wild prototype was discovered only quite recently." It is the "Jedogawa-tsutsuji with white flowers" mentioned by Kaempfer (Amoen. Exot. 848 [1712]), and by Thunberg was included under his Azalea indica as "Yedogawa Satsuke." It was cultivated in Java in the days of Burmann and without doubt was brought there from Nagasaki, Japan, by Dutch trading ships. In China it is grown in the gardens of the wealthy in many parts of the Empire, but how it got there we do not know. According to Lindley (Bot. Reg. X. t. 811 [1824]) it was first introduced into England to the nurseries of Mr. Brookes at Ball's Pond through his collector Joseph Poole who sent it from Chins in 1819. Like all introductions of this period it came, in all probability, either from Canton or Macao. Probably there were other importations from China in early times and during the last thirty years hundreds of thousands of plants have been sent from Japan to America and Europe. Its fragrant, white flowers and good constitution have made it a favorite and common plant in the greenhouses of the west. In fairly recent years it has been found to be more hardy than was once supposed, and it is now quite frequently seen as an outdoor garden shrub. I have not been able to ascertain the exact date of its introduction into America, but Hovey tells us that it was growing in the garden of J. P. Cushing, Belmont Place, Watertown, Massachusetts, in February, 1838. It is scarcely hardy near Boston but on Long Island, New York, and southward it is perfectly hardy. In Japan it is known as the "Shiro-yodogawa," that is "White Yodogawa."

I am familiar with this plant in the gardens of Japan and China as well as in those of Europe and America and in addition to the material enumerated I have seen the many old specimens preserved in Herb. Kew and Herb. Gray, which include several sent from Java many years ago. Every specimen in herbaria that I have seen is definitely stated to have come from cultivated plants. That it is an albino form of some species has long been suspected and it is satisfactory to be able to identify it at last. After an exhaustive study I am of the definite opinion that this old favorite garden plant is a white-flowered form of a plant wild near the banks of rivers on the island of Shikoku, which has lilac-purple flowers and to which Makino (in Tokyo Bot. Mag. XXII. 55 (1908) has given the name R. ripense.

1 Millais states that "Carles collected it on the Seoul mountains in Korea." This is incorrect; the plant is $R$. yedoense var. poukhanense Nakai. 
The specific name here employed to designate this species is the oldest valid name but it seems to have been quite overlooked. Burmann named the plant Azalea rosmarinifolia in $\mathbf{1 7 6 8 .}$. This is the oldest name but unfortunately it was neglected for over a century and became invalidated under Rhododendron by the $\boldsymbol{R}$. rosmarinifolium Vidal, a Philippine species, some years before it was taken up for Burmann's plant by Dippel.

A form with larger flowers than the type is:-

Rhododendron mucronatum f. Noordtianum Wilson, n. comb.

Azalea japonica alba grandiflora van Noordt Pynaert in Rev. Hort. Belg. XXX. 133, t. (1904), 一 Reuter in Möller's Deutsch.Gärtn. Zeit. XX. 73, fig. (1905).

Azalea ledifolia var. Noordtiana Wittmack in Gartenfl. LIX. 310 , fig. 32 (1910).

Rhododendron ledifolium var. Noordtianum Rehder in Mitt. Deutsch. Ges. XXIV. 225 (1916).

Rhododendron rosmarinifolium f. Oriukiu Komatsu in Tokyo Bot. Mag. XXXII. [35] (1918).

Japan: Hondo, prov. Kawachi, Ikeda, cultivated, May 8, 1918, E. H. Wilson.

Pynaert states that this form was raised in the nursery of $P$. van Noordt \& Sons, Boskoop, from seeds collected from some plants introduced from Japan. I can find no difference between it and the form long cultivated in Japan under the name of $\bar{O}$-riukiu-tsutsuji (large Liukiu Azalea). It is considered in Europe to be a very hardy form of the type.

Very similar to the last-named form is: -

\section{Rhododendron mucronatum "Mattapan" Wilson, n. f.}

Azalea "Mattapan" C. M. Hovey, Mag. Hort. XXVII. 190 (1861).

This plant was exhibited for the first time before the Massachusetts Horticultural Society on March 23, 1861, by C. M. Hovey, and described as " a new seedling, flowers white with a yellowish blotch on the upper petals which are fringed in the way of A. crispiflora." This handsome form is still in the Holm Lea collection and in other gardens round Boston, Mass. In some gardens this Azalea is known by the name of "America."

A form with double white flowers is: -

Rhododendron mucronatum f. narcissifforum Wilson, n. comb.

Rhododendron narcissiflorum Planchon in Fl. des Serr. IX. 82 (1854); in Rev. Hort. 1854, 67. - Hemsley in Jour. Linn. Soc. XXVI. 27 (1889). - Millais, Rhodod. 216 (1917).

Azalea narcissiflora Fortune apud Planchon in Fl. des Serr. IX. 82 (1854), as a synonym. - Hovey, Mag. Hort. XXII. 9 (1856).

Rhododendron ledifolium $\gamma$. narcissiflorum Maximowicz in Mém. Acad. Sci. St. Pétersbourg, sér. 7, XVI. No. 9, 36 (Rhodod. As. Or.) (1870), in part. Franchet \& Savatier, Enum. Pl. Jap. I. 291 (1875). - Matsumura, Ind. Pl. Jap. II. pt. 2, 462 (1912). - Bean, Trees and Shrubs Brit. Isl. II. 366 (1914). - Rehder in Bailey, Stand. Cycl. Hort. V. 2944 (1916).

Azalea rosmarinifolia var. narcissiflora Rehder in Bailey, Cycl. Am. Hort. 123 (1900). 
Rhododendron rosmarinifolium var. narcissiflomum Schneider, Ill. Handb. Laubholzk. II. 504 (1911).

Rhododendron rosmarinifolium f. narcissiflorum a. Shiromanyo Komatsu in Tokyo Bot. Mag. XXXII. [36] (1918).

Japan: Kyushu, prov. Chikugo, Kurume, cultivated, May 3, 1918, E. H. Wilson.

Under the name of "Shiro-manyo-tsutsuji" this double-flowered form has been cultivated in Japan for a long time - probably centuries. It was introduced into England by Robert Fortune who sent plants from China to Messers Standish \& Noble about 1850 or 1851 . It was imported into this country by C. M. Hovey in 1855. Hovey (Mag. Hort. V. 25 [1839]) speaks of an Azalea ledifolia alba pleno having been introduced into Boston in 1838. The name guggests that the form narcissiflorum may have been in gardens prior to Fortune's introduction but I have been unable to find any further reference to the plant mentioned by Hovey. Mil. lais suggests this may be a hybrid $R$. indicum $\times R$. linearifolium but it is difficult to understand why it should be regarded as anything but the common R. mucronatum G. Don (Azalea ledifolia Hook.) with double flowers. The habit, fragrance, calyx and pubescence are identical. Maximowicz refers the double rosecolored form (f. plenum Wils.) to this f. natcissiflorum and Millais does the same but for horticultural purposes it is best kept distinct.

A fine garden form of the type is: -

Rhododendron mucronatum f. sekidera Wilson, $n$. comb.

Rhododendron rosmarinifolium f. Sekidera Komstsu in Tokyo Bot. Map. XXXII. [35] (1918).

Rhododendron Sekidera (Rhod. indicum $\times$ Rhod. Kaempferi) Komatsu in Tokyo Bot. Mag. XXXII. [46] (1918).

Azalea magnifica Hort. Yokohama Nursery Co. Cat. 1918-19, p. 19.

Azalea indica roseum Hort. Andorra Nurseries, May, 1919.

Azalea japonica grandiflora superba Hort. Andorra Nurseries, May, 1919.

Azalea “Damask Rose” Hort. Andorra Nurseries, May, 1919.

Japan: prov. Musashi, cultivated, May 21, 1914, E. H. Wilson (No. 6670).

This very handsome plant I saw cultivated in the grounds of the Yokohams Nursery Company. The flowers are as large as those of $f$. Noordtianum, pure white with the dorsal lobes spotted and splashed with rose, occasionally a flower is rose-colored; the stamens vary in number from 6 to 10 but are usually 10 . Under the names Azalea indica roseum and Azalea "Damask Rose" slightly inferior forms were sent to us for determination last year. The true variety is cultivated by Mr. John S. Ames, North Easton, Mass., who imported it in 1917. In 1919 I brought back plants from Japan to the Arnold Arboretum. This most desirable addition to our gardens will probably prove to be as hardy as the typical whiteflowered $R$. mucronatum G. Don.

A spontaneous variety and undoubtedly the phylogenetic type of the species is: -

Rhododendron mucronatum var. ripense Wilson, n. comb.

Rhododendron ripense Makino in Tokyo Bot. Mag. XXII. 55 (1908). - Schneider, IL. Handb. Laubholzk. II. 503 (1911). - Komatsu in Icon. Pl. Koisikav. II. 71, t. 120 (1914); in Tokyo Bot. Mag. XXXII. [12] (1918). 
Japan: Kyushu, prov. Hizen, Nagasaki, common in gardens, March 19, 1914, E. H. Wilson (No. 6316); prov. Chikugo, Kurume, cultivated, May 3, 1918, E. H. Wilson.

Cultivated: Garden of Butler Plantation, West Feliciana Parish, Louisiana, March 28, 1910, C. S. Sargent.

I have examined the type of Makino's $R$. ripense and can find no character by which it differs from $R$. mucronalum $G$. Don, except in the rose-purple color of its flowers, and as is well known a branch bearing colored flowers is often found in Don's species. Nevertheless, Makino's discovery is most interesting since it enables us to place definitely the habitat and parentage of $R$. mucronatum G. Don which has remained obscure for over a century and a half. Makino gives two localities and says that it is found wild by the side of rivers in Tosa and Iyo provinces in Shikoku, and also that it is frequently cultivated. I have seen it only as a cultivated plant in Japan where it is not by any means such a general favorite as the pure white form. I saw more plants round Nagasaki than elsewhere. At Kurume it is known as the "Momo-iro-yodogawa." Makino gives the vernacular name in Tosa province as "Iso-tsutsuji."

There is in cultivation in this country an intermediate and very lovely form in which the corolla is white, delicately flushed with pale lilac-purple and has a few very faint rose-pink spots. As a garden plant it is distinct and desirable and it may be called:-

R. mucronatum $\mathrm{f}$. amethystinum Wilson, $\mathrm{n}$. $\mathrm{f}$.

Cultivated: Hort. Farquhar \& Co., Boston, Mass., April 1, 1909, (type). Hort. Andorra Nurseries, Chestnut Hill, Philadelphia, Pa., May 20, 1920, as Azalea japonica alba.

Rhododendron mucronatum f. plenum Wilson, n. comb.

Azalea indica var. $\beta$. plena Sims in Bot. Mag. LI. t. 2509 (1824).

Azalea indica $\gamma$. purpurea Sweet, Hort. Brit. 264 (1827).

Azalea prolifera Poiteau in Annal. de From. I. 104 (1829).

Rhododendron phoeniceum var. $\beta$. flore pleno G. Don, Gen. Syst. III. 846 (1834).

Azalea purpurea pleno Hovey, Mag. Hort. V. 115 (1839).

Rhododendron indicum ร. incarnatum De Candolle, Prodr. 726 (1839).

Rhododendron ledifolium $\gamma$. narcissiflorum Maximowicz in Mém. Acad. Sci. St. Pétersbourg, sér. 7, XVI. No. 9, 36 (Rhodod. As. Or.) (1870), in part.

Rhododendron ledifolium var. plena purpurea Regel in Gartenfl. XXXV. 565, t. 1233, fig. c-d (1886).

Azalea indica purpurea plena Bretschneider, Hist. European Bot. Disc. Chin. 222 (1898).

Rhododendron rosmarinifolium f. narcissiflorum $\beta$. Fujimanyo Komatsu in Tokyo Bot. Mag. XXXII. [36] (1918).

Japan: Hondo, prov. Kawachi, Ikeda, cultivated, May 8, 1918, E. H. Wilson.

Cultivated : Hort. Holm Lea, Brookline, Mass.

Round Tokyo and Yokohama this plant is known as Fujimanyo; round Osaka it is the Murasaki-botan-tsutsuji (purple Paeony Azalea). It is an old plant even 
in western gardens, having been sent by Joseph Poole from China to Samuel Brookes, nurseryman, Ball's Pond, Newington Green, England, in 1819. The flower is rosepurple, fragrant, quite, or only partially double, and with or without green rudimentary leaves showing in the centre of the flower. Hovey tells us that this plant was cultivated by Mrs. Hibbert and exhibited before the Pennsylvania Horticultural Society on February 19, 1839.

Rhododendron linearifolium Siebold \& Zuccarini in $A b h . A k a d$. Münch. IV. pt. III. 131 (Fl. Jap. Nat. II. 7) (1846).- Miquel in Ann. Mus. Lugd.-Bat. I. 34 (1863); II. 165 (1864-66); Prol. Fl. Jap. 97 (1866-67). - Maximowicz in Mém. Acad. Sci. Pétersbourg, sér. 7, XVI. No. 9, 34 (Rhodod. As. Or.) (1870). - Franchet \& Savatier, Enum. Pl. Jap. I. 290 (1875). - Boissier in Bull. Herb. Boiss. V. 918 (1897). - Schneider, Ill. Handb. Laubholzk. II. 504, figs. $330 \mathrm{~g}-\mathrm{k}$, 331 f. (1911). - Matsumura, Ind. Pl. Jap. II. pt. 2, 463 (1912). Bean, Trees and Shrubs Brit. Isl. II. 366 (1914). - Millais, Rhodod. 203 (1917).

Azalea linearifolia Hooker f. in Bot. Mag. XCV. t. 5769 (1869).

Rhododendron macrosepalum var. linearifolium Makino in Tokyo Bot. Mag. XXII. 55 (1908). - Komatsu in Tokyo Bot. Mag. XXXII. [34] (1918).

Rhododendron linearifolium a. linearifolium Makino in Tokyo Bot. Mag. XXVII. 108 (1913).

Cultivated: November, 1867, February, 1869, ex Hort. Standish (Herb. Kew); 1876, ex Hort. Hunnewell (Herb. Gray).

This is a monstrous garden form cultivated in Japan but rather rare. The leaves are narrow, strap-shaped, and the corolla is divided into narrow, ligulate gegments. An analogous plant is $R$. indicum f. polypetalum Wils. Maximowicz says it was introduced into the gardens of Tokyo from the alpine regions of Sendai in northern Japan. This is a mistake. It is unknown in a wild state and was first known from the neighborhood of Nagasaki in Kyushu the southern island of Japan. Its Japanese name is "Seigai-tsutsuji." It was introduced into England by Messers Standish with whom it flowered in November, 1867, and again in February, 1869. It is well figured in the Botanical Magazine. From England it appears to have been sent to this country for it flowered in the garden of Mr. H. H. Hunnewell, Wellesley, Mass., in 1876. According to Bean it is quite hardy at Kew. It is not hardy in the Arnold Arboretum and I do not know whether it is now cultivated in America.

Rhododendron linearifolium var. macrosepalum Makino in Tokyo Bot. Mag. XXVII. 108 (1913).

Rhododendron macrosepalum Maximowicz in Gartenfl. XIX. 258, t. 662 (1870); in Mém. Acad. Sci. St. Pétersbourg, sér. 7, XVI. No. 9, 31 (Rhodod. As. Or.) (1870); in Bull. Acad. St. Pétersbourg, sér. III. XV. 227 (Mél. Biol. VII. 335) (1871). - Franchet \& Savatier, Enum. Pl. Jap. I. 290 (1875). - Dippel, Handb. Laubholzk. I. 420, fig. 271 (1889). - Makino in Tokyo Bot. Mag. IV. 151 (1890); XXII. 55 (1908). - Boissier in Bull. Herb. Boiss. V. 918 (1897). - Schneider, Ill. Handb. Laubholak. II. 503, figs. 330 e, 331 a-b 
(1911). - Matsumura, Ind. Pl. Jap. II. pt. 2, 463 (1912). - Millais, Rhodod. 205 (1917). — Komatsu in Tokyo Bot. Mag. XXXII. [13] (1918).

Azalea macrosepala K. Koch, Dendr. II. pt. 1, 180 (1872). - O. Kuntze, Rev. Gen. II. 387 (1891).

Rhododendron linearifolium $\beta$. macrosepalum forma «. genuinum Makino in Tokyo Bot. Mag. XXVII. 108 (1913).

Japan: Kyushu, prov. Hizen, roadside, Nagasaki to Mogi, November 12, 1903, C. S. Sargent. Shikoku, prov. Tosa, thickets up to 300 m. alt. November 20, 1914, E. H. Wilson (No. 7794). Hondo, prov. Settsu, near Kobe, April, 1875, H. N. Moseley (Herb. Kew); prov. Kawachi, Yomomoto and Ikeda, May 8, 1918, E. H. Wilson (No. 10,355); prov. Yamato, Koyasan, August 26, 1907, U. Faurie (No. 124); Yoshino, April 22, 1914, E. H.Wilson (No. 6574, in part); prov. Yamashiro, Kyoto, Temple Garden, October 16, 1892, C. S. Sargent; Kyoto, J. Rein, ex Mus. Bot. Berol. (Herb. Bur. Sci. Manila); prov. Omi, mountains round Lake Biwa, April 30, 1892, U. Faurie (No. 7820, Herb. Kew); prov. Mino, Pine-barrens near Gifu, October 20, 1892, C. S. Sargent; prov. Mikawa, Pine-woods, Futagawa, May 9, 1918, E. H. Wilson (Nos. 10,346, 10,348, 10,349); prov. Shimotsuke "alpe Niko," 1866-74, L. Savatier (No. 766, Herb. Kew).

This is the Mochi-tsutsuji (Glandular Azalea) of Japan, where it is common in central Hondo at low altitudes from near Osaka north to Hamamatsu in Totomi province; also in Tosa province, Shikoku. It is partial to gravelly soil and dry eituations such as Pine-woods and open thickets afford. A social plant it occurs in great numbers either alone or with $R$. obtuisum var. Kaempferi Wils. At Futagawa, for instance, in Pine-woods these two species grow in thousands and in early May when in full blossom they are conspicuous from the railway carriage windows. The specimen from Nagasaki is probably from an escaped plant and there is no other record of its growing in Kyushu. North of Totomi province I have not seen it wild, and I think there is some mistake about it being indigenous in the Nikko region, Maximowicz's statements and Savatier's specimens notwithstanding. It is not mentioned by Matsumura in his Plants of Nikko nor by Hayata in his Vegetation of Mt. Fuji.

As usually seen $R$. linearifolium var. macrosepalum is a low, rather laxly branched shrub spreading in habit and less than one metre high but in Shikoku I saw it full three metres tall. It has the usual dimorphic leaves and these are mostly deciduous. The shoots are terete and with the petioles are densely clothed with gray to gray-brown pilose (some of them gland-tipped) hairs and a few flattened, spreading bristles which disappear in the second season; the winter-buds are ovoid, acute, densely covered with strigose, yellow-brown hairs. The leaves are membranous, scattered on the free-growing shoots and crowded on others, shortpetioled, lanceolate-ovate to ovate-elliptic, sometimes lanceolate or ovate, short acuminate, acute or merely mucronulate; those immediately beneath the winterbuds oblanceolate to oblanceolate-oblong obtuse, or rounded, usually mucronulate, the under surface clothed with soft, spreading, gray to gray-brown glandular hairs, the upper surface sparsely glandular hairy, slightly rugulose and hispid; dull green during summer changing to rich vinous purple in the autumn. The flowers are 
fragrant, from 2 to 10 in terminal umbels, very variable in size and form. The pedicels are from 2 to $4 \mathrm{~cm}$. long, straight or spreading, densely glandular and pilose. The calyx is green, glandular-pubescent and very variable in size, the etrap-shaped segments being from 1 to $3 \mathrm{~cm}$. long and occasionally exceeding the rose-pink to red-purple corolla, which is broad funnel-shape, sometimes $5 \mathrm{~cm}$. but often not more than $3 \mathrm{~cm}$. across; it is glabrous without, and normally larger than the calyx. Stamens normally 5, but at Ikeda I gathered specimens with from 6 to 10 stamens; they are shorter than the pistil and included within the corolla except in abnormally small flowers. The fruit is narrow-ovoid, about $1 \mathrm{~cm}$. long, glandular-pubescent, purplish-brown in color and subtended by the persistent calyx the lobes of which are reflexed, brown without and wine-purple on the inside. There can be no question of this being the phylogenetic type of the species and it is unfortunate that it should have to rank as a variety. Even in a wild state it is a very variable plant, and a number of forms have been detected and are cultivated in Japanese gardens; these are dealt with hereafter. The calyx, pedicels and innermost scales of the flower-buds are always glandular, usually densely so and commonly sufficiently viscid to hold gnats and small flies captive, but this viscosity like everything else in this plant is variable. The flowers are pleasantly fragrant and some of the color forms are very handsome. When the flowers have a comparatively small corolla and very long calyx-lobes the effect is curious. This Azalez was introduced into Petrograd by Maximowicz who sent seeds in 1863. It flowered for the first time in 1870 and is well figured in Gartenflora. Maximowicz claims that the seeds and his two plants came from the Nikko alps but if this is not a mistake it is strange that no other collector has seen the plant in this locality which is fully two hundred miles north of where it has been seen wild by subsequent observers. Further, no one else has found it in alpine regions anywhere in Japan. However, there is no doubt that the plant under discussion is Maximowicz's species. What happened to the original introduction I do not know but neither Bean nor Millais mention its cultivation in England. In 1914 I sent to the Arnold Arboretum seeds of this plant from Shikoku some of which were sent to England. Plants raised from this seed in the Arnold Arboretum have not proved very hardy.

A form with double flowers is:-

Rhododendron linearifolium var. macrosepalum f. dianthiflorum Wilson, n. comb.

Azalea dianthiflora Carrière in Rev. Hort. 1889, 391; 1891, 60, fig. 18, t. Rhododendron dianthiflorum Millais, Rhodod. 155 (1917).

Japan: Hondo, prov. Mikawa, Pine-woods, Futagawa, May 9, 1918, E. H. Wilson (No. 10,350).

Cultivated: ex Hort. James Veitch \& Sons, June 28, 1904 (Herb. Kew).

I have seen at Futagawa one or two plants growing wild with double flowers. The pedicels are more spreading than in the type and the calyx-lobes are variable in length. Carrière's figures give a good idea of this form except that the color is brighter and more pleasing than the plate shows. According to Carrière it was introduced into France from Japan in 1889 by M. Wiesener, of Fontenay-auxRoses. The specimen in Herb. Kew shows that it was cultivated by Messers Veitch in 1904. Bean does not mention it and Millais's account is abbreviated from Carrière's description. I have no knowledge of its being in the gardens of this country. 
Another spontaneous form is: -

Rhododendron linearifolium var. macrosepalum f. decandrum Wilson, $n$. $f$.

Japan : Hondo, prov. Kawachi, Yomomoto, roadside, Pine-woods, May 8, 1918, E. H. Wilson (No. 10,355a, type); Ikeda, cultivated, May 8, 1918, E. H. Wilson; prov. Yamato, near Yoshino, dry woods, April 22, 1914, (No. 6574, in part).

This differs from the type in having 10 stamens; the Ikeda specimens have from 6 to 10 stamens and that from Yoshino (a fragment) has 6 only. The typical var. macrosepalum is common round Yomomoto where it is known as the Yama-tsutsuji (Mountain Azalea) and growing with it I found occasional plants with 10 or from 6 to 10 stamens in each flower. I have seen none with from 5 to 10 stamens and I do not remember whether the fragment from near Yoshino came from a bush of the ordinary 5 -stamen type.

An anomalous form is:-

Rhododendron linearifolium var. macrosepalum f. rhodoroides Makino in Tokyo Bot. Mag. XXVII. 109 (1913).

Rhododendron macrosepalum $\beta$, rhodoroides Maximowicz in Mém. Acad. Sci. St. Pétersbourg, sér. 7, XVI. No. 9, 31 (Rhodod. As. Or.) (1870).-Franchet \& Savatier,"Enum. Pl. Jap. I. 290 (1875). - Matsumura, Ind. Pl. Jap. II.pt. 2, 463 (1912). - Komatsu in 'Tokyo Bot. Mag. XXXII. [34] (1918).

Rhododendron ledifolium var. Kochozoroi Komatsu apud Makino in Tokyo Bot. Mag. XXVII. 109 (1913), as a synonym.

Japan: Hondo, prov. Kawachi, cultivated, Yamomoto and Ikeda, May 8, 1918, E. H. Wilson; prov. Musashi, Okbo, cultivated, May 18, 1909, K. Ōnuma; Hatagaya, cultivated, April 29, 1914, E. H. Wilson (No. 6596).

This is a curious form often seen in Japanese gardens. It has a deeply cleft 5-partite corolla only slightly longer than the calyx-lobes, and greenish-white shaded with rose, exserted stamens with pale purple anthers exceeded in length by the style. Maximowicz raised seedlings from this plant and states that in every instance they reverted to typical var. macrosepalum. Makino gives "Kocho-zoroi" as the Japanese name of this plant; in the nursery district near Osaka it is known as "Seikan-tsutsuji."

Another anomalous form is:-

Rhododendron linearifolium var. macrosepalum f. hanaguruma Makino in Tokyo Bot. Mag. XXVII. 109 (1913).

Rhododendron ledifolium var. leucanthum f. Hanaguruma Komatsu apud Makino in Tokyo Bot. Mag. XXVII. 109 (1913), as a synonym.

Rhododendron macrosepalum var. Hanaguruma Makino in Tokyo Bot. Mag. XXVII. 109 (1913), as a synonym. - Komatsu in Tokyo Bot. Mag. XXXII. [35] (1918).

Rhododendron linearifolium var. macrosepalum f. polypetalum Makino in Tokyo Bot. Mag. XXVII. 109 (1913), as a synonym. 
Japan : Hondo, prov. Kawachi, cultivated at Yomomoto and Ikeda, May 8, 1918, E. H. Wilson; prov. Rikuzen, Sendai, cultivated, May 27, 1888, U. Faurie (No. 2300, Herb. Kew).

Cultivated: ex Hort. Ball, March, 1879 (Herb. Kew).

In this form the corolla is rose-purple in color, deeply cleft and 5-partite, and the stamens are usually shorter than the corolla-lobes which are from 2.5 to $4 \mathrm{~cm}$. long. Makino gives "Hana-guruma" as the Japanese name; in the nursery diotrict near Osaka it is known as "Oyeyama-tsutsuji." The specimen in Herb. Kew proves that at one time it was in cultivation in England.

Komatsu (in Tokyo Bot. Mag. XXXII. [34] [1918]) enumerates three other forms ("Usuyo," "Amaga-shita" and "Suruga-momyo") of this species, but these are unknown to me.

These are all the species of the section Tsutsutsi that are named or of which I have seen sufficient material. There is, however, in this herbarium specimens (ex Herb. Hongkong Nos. 7030, 5612) from Taimo-shan, Kowloon, Kwangtung province, of a curious Azalea. It has narrow, linear-lanceolate, acuminate leaves and inconspicuous subsessile flowers with the corolla deeply divided into five narrow gegments. It is in every way anomalous, and probably a monstrous condition of some species not yet described, or possibly of the widespread $R$. Simsii Planch. We have, also, a leafy fragment, collected in Kweichou province by Dr. HandelMazzetti (No. 221, July 11, [1917]) which probably belongs to a new species ro lated to $R$. Oldhamii Maxim. 


\section{SeCT. II. SCIADORHODION REHD. \& WiLS., n. sect. ${ }^{1}$}

Rhododendron section Tsutsutsi G. Don, Gen. Syst. III. 847 (1834), as to species nos. 30, 31. - Rehder \& Wilson in Sargent, Pl. Wilson. I. 547 (1913), in part.

Rhododendron subgenus Tsutsia Planchon in Fl. des Serr. XI. 75 (1854); in Rev. Hort. 1854, 43, as to R. Farrerae.

Rhododendron section Azalea Maximowicz in Mém. Acad. Sci. St. Pétersbourg, sér. 7, XVI. No. 9, 24 (Rhodod. As. Or.) (1870), in part.

Azalea subgenus Euazalea K. Koch, Dendr. II. pt. 1, 179 (1872), as to $A$. reticulata.

Rhododendron section Rhodora Dippel, Handb. Laubholzk. I. 418 (1889), in part.

Shrubs with rigid, usually verticillate, often ascending-spreading branches and glabrous or villose shoots without bristle-like hairs. Flowers from terminal buds, with leafy shoots from axils of lower scales of the same bud. Leaves deciduous, in whorls of 3 to 5 at the end of the branchlets, on vigorous shoots scattered, not dimorphic, usually rhombic to obovate, rarely ovate, without appressed bristle-like hairs. Corolla rotate-campanulate, rarely rotate-funnel-form; stamens from 6 to 10 (rarely 5 by abortion), unequal, sometimes declinate. Fruit oblongovoid to cylindric, rarely conic-ovoid, of ten furrowed, villose or glandular, never strigose.

This section is found only in eastern Asia, where it is represented by 6 species.

Rhododendron Farrerae Tate apud Sweet, Brit. Flow. Gard. ser. 2, I. t. 95 (1831). - G. Don, Gen. Syst. III. 846 (1834). - De Candolle, Prodr. VII. 725, pt. 2 (1839). - Planchon in Fl. des Serr. XIX. 80 (1854); in Rev. Hort. 1854, 64. - Maximowicz in Mém. Acad. Sci. St. Pétersbourg, sér. 7, XVI. No. 9, 25 (Rhodod. As. Or.) (1870).-Hance in Jour. Linn. Soc. XIII. 110 (1873). - Hemsley in Jour. Linn. Soc.

1 Sectio inter sect. Tsutsutsi et Rhodoram medium tenens, a priori indumento piloso vel villoso pallido, non strigoso et fusco, foliis semper deciduis satis magnis, corolla rotato vel rotato-campanulata, ovario villoso vel glabro, non strigoso, a posteriori gemmis terminalibus flores et folia simul proferentibus bene differt, ab utraque sectione foliis in apice ramulorum subverticillatim congestis quasi umbellam vel umbraculum (graece $\sigma \kappa \iota \dot{\alpha} s$, $\sigma \kappa \iota a ́ \delta o s$, unde nomen) formantibus satis magnis plerumque late obovatis vel rhombico-ovatis distat.

In Sargent, Plantae Wilsonianae, I. 548 (1913), we suggested that with their whorled leaves the species here enumerated formed a well-marked group easily distinguished from Tsutsutsi, although agreeing in the character of the winterbuds. Further investigation has brought to light other differences and we are of the opinion that it is best to place them in a distinct section.

A. R. \& E. H. W. 
XXVI. 23 (1889); in Kew Bull. Misc. Inform. 1907, 245. - Dunn \& Tutcher in Kew Bull. Misc. Inform. add. ser. X. 155 (Fl. Kwangtung and Hongk.) (1912). - Millais, Rhodod. 163 (1917).

Azalea squamata Lindley in Jour. Hort. Soc. Lond. 1.152 (1846); in Bot. Reg. XXXIII. t. 3 (1847). - Walpers, Ann. I. 481 (1848-49). - Bentham, $F l$. Hongk. 201 (1861).

Azalea Farrerae K. Koch, Dendr. II. pt. 1, 178 (1872). - O. Kuntze, Rev. Gen. pt. 2, 387 (1891).

Azalea squamosa O. Kuntze, Rev. Gen. pt. 2, 387 (1891), as a synonym.

Rhododendron Farterae $\delta$. typicum Diels in Bot. Jahrb. XXIX. 514 (1900).

China: prov. Kwangtung, Loh-fau-san, August 21, 1917, C. 0. Levine (ex Canton Christian College Herb. No. 1533).

This species seems to be peculiar to Hongkong and the neighboring islands and to the adjacent parts of Kwangtung province. It is a low, densely branched shrub with short, rigid, shining brown, verticillate branchlets clothed with appressed, straight and villose hairs when young, becoming glabrous and gray in their second year. The leaves are crowded, usually in threes at the end of the branches, subcoriaceous, deciduous or semi-persistent, glabrescent, ovate, from 2 to $3 \mathrm{~cm}$. long and from 1.2 to $2 \mathrm{~cm}$. wide, acute or sub-acute, with a short mucro, and a rounded base; they are dark green above and pallid below, reticulate, with the principal veins impressed above and raised below. The petioles are from 1 to $3 \mathrm{~mm}$. long and densely villose. The winter-buds are small, broadly ovoid, and are densely clothed with gray or rufous pubescence. The flowers appear before the leaves unfold, either solitary or in pairs at the end of the branches. The corolla is pale to deep rose-color with red-purple spots, from 4 to $5 \mathrm{~cm}$. in diameter; it has a short, narrow, funnel-shape tube and spreading, undulate lobes. The ring-like calyx is minutely 5-toothed, and pubescent; and the pedicel and ovary are thickly clothed with appressed and villose, ferrugineous or gray hairs. The stamens are from 8 to 10 of unequal length and shorter than the corolla, and are equalled or slightly overtopped by the slender, curved style. The fruit is conic-ovoid, from 0.5 to $1.5 \mathrm{~cm}$. long and from 0.8 to $1 \mathrm{~cm}$. in diameter and densely villose, and is borne on a stout, curved, villose pedicel about $1 \mathrm{~cm}$. long.

I have seen this Azalea growing wild in Hongkong and as Hemsley has pointed out it is a very distinct species. It is characterized by its small, ovate leaves, its very short villose petioles and by its relatively large fruit. It was first introduced into England in 1829, by Captain Farrer of the East India Company's ship "Orwell." It was reintroduced by Robert Fortune who in 1844 sent it to the garden of the Horticultural Society of London where it flowered and was renamed by Lindley. I have no knowledge of its having been in cultivation in America, and Millais states that it is a rare plant in English gardens, and hardy only in the Bouth.

Rhododendron Mariesii Hemsley and Wilson in Kew Bull. Misc. Inform. 1907, 244. - Hutchinson in Bot. Mag. CXXXIV. t. 8206 (1908). - Schneider, Ill. Handb. Laubholzk. II. 496, fig. 327 I-m (1909). - Rehder \& Wilson in Sargent, Pl. Wilson. I. 548 (1913).Bean, Trees and Shrubs Brit. Isl. II. 377 (1914). - Millais, Rhodod. 207 (1917). 
Rhododendron Weyrichii Hemsley in Jour. Linn. Soc. XXVI. 32 (1889), not Maximowicz.

Rhododendron Farrerae a. leucotrichum Franchet in Jour. de Bot. IX. 394 (1895). - Diels in Bot. Jahrb. XXIX. 513 (1900). - Millais, Rhodod. 163 (1917).

Rhododendron Farrerae a. Weyrichii Diels in Bot. Jahrb. XXIX. 513 (1900).

Rhododendron Farrerae $\gamma$. mediocre Diels in Bot. Jahrb. XXIX. 514 (1900).

Rhododendron rhombicum Diels in Bot. Jahrb. XXIX. 514 (1900), not Miquel.

Rhododendron Farrerae Kawakami, Pl. Formos. 64 (1910), not Tate.

Rhododendron shojoense Hayata in Jour. Coll. Sci. Tokyo, XXX. art. 1, 174 (1911).

Rhododendron gnaphalocarpum Hayata, Icon. Pl. Formos. III. 132 (1913).Kanehira, Formos. Trees, 327, fig. 14 (1917).

China: without locality, 1845, R. Fortune (No. 122 (2), Herb. Kew); prov. Fokien, April to June, 1905, Dunn's Exped. (Hongk. Herb. No. 2882); prov. Chekiang, Taihu Lake, near Huchau, April, 1881, $W$. R. Carles (No. 117, Herb. Kew); prov. Kiangsi, Kuling, 1878, C. Maries (Herb. Kew); same locality, alt. 1300 m. July 29, 1907, E. H. Wilson (No. 1681); prov. Hupeh, Changyang Hsien, A. Henry (Nos. 1422, 5274, 5946, Herb. Kew, Herb. Gray); Nanto and mountains to northward, A. Henry (No. 3829, Herb. Kew, Herb. Gray); north and south of Ichang, alt. 300-1300 m. May and November, 1907, E. H. Wilson (No. 606, in part); south of Ichang, alt. $800 \mathrm{~m}$. April and October, 1900, E. H. Wilson (Veitch Exped. No. 29, type); Hsingshan Hsien, alt. 1300, May 12, 1907, E. H.Wilson (No. 606 in part); prov. Szech'uan, Nanch'uan, A. von Rosthorn (No. 2164, Herb. Christiania).

Cultivated: ex Hort. Veitch, April, 1907 (Herb. Kew, type of Bot. Mag. t. 8206).

This species is distributed from Fokien and Chekiang provinces of eastern China westward to southeastern Szech'uan. On the Lushan mountains round Kuling it is common and north and south of Ichang it is very plentiful on cliffs and in thickets between altitudes of 300 and $1300 \mathrm{~m}$. Its pleasing pink to rosecolored flowers open before the leaves unfold and in late April and May it is a conspicuous wayside shrub. Curiously this and $R$. molle G. Don are the only deciduous leafed species in the whole of China except $R$. Farrerae Tate from Hongkong and the adjacent territory. Maries' Azalea is an upright branching shrub from 1 to $3 \mathrm{~m}$. tall, rather narrow, with verticillate, twiggy, ascending branches which are shining, yellow or chestnut-brown during the first year and afterward pale gray. When young the shoots and leaves are covered with yellowish, appressed silky hairs which usually fall away early or may in part persist on the shoot through the entire season. The buds are conic, gray-purple, with ciliate bud-scales glabrescent without and villose on the inner surface. The leaves at maturity are chartaceous, dark green above, pallid below, prominently reticulate, with the principal veins slightly impressed on the upper side and raised on the lower side; they vary from $3.5 \mathrm{~cm}$. to $7.5 \mathrm{~cm}$. in length and from 2 to $4 \mathrm{~cm}$. in width, and are always the broadest below the middle. The prevailing shape is 
orate-lanceolate, with an acute mucronate apex and cuneate base, but occasionally they are broad-ovate or elliptic. The petioles are from 0.4 to $1.2 \mathrm{~cm}$. in length, glabrescent, purplish, and of ten slightly glaucescent on the under-side. The flowers are usually in pairs at the end of the naked branchlets, but are sometimes solitary, and occasionally are in 4- or 5-flowered elusters; the corolla is from 4 to $5 \mathrm{~cm}$. across, spotted with red-purple on the posterior lobes; it has a short, narrow, funnel-shape tube and deeply cleft, spreading lobes. The pedicels are villose; the minute, 5-lobed calyx and the ovary are clothed with gray or yellow-brown, straight appressed hairs. The 10 stamens are of nearly equal length and as long as the corolla, the filaments are glabrous, curved and the anthers purple. The style is longer than the stamens and is curved upward and has a capitate, slightly lobed stigma. The fruit is cylindric, from 1 to $1.5 \mathrm{~cm}$. long, slightly furrowed, and clothed with gray or yellow-brown, villose pubescence, and is borne on a straight pedicel.

From those species with which $R$. Mariesii has been confused it is readily distinguished by its leaves. The flowers are of a different color from those of the Japanese species, the corolla is differently shaped and there are other distinctions of importance. In Tokyo I saw the types of Hayata's two species cited and could find nothing by which to distinguish them from $R$. Mariesii.

This Chinese plant was discovered by Fortune, probably in Chekiang province, and afterward by Charles Maries on the Lushan mountains behind Kiukiang in the spring of 1878. It was introduced into Kew gardens through seeds sent from the neighborhood of Ichang in 1886 by Augustine Henry; in 1900 I sent seeds to Messers Veitch from south of Ichang. This Azalea flowered for the first time in the Temperate House at Kew in April, 1907. Bean does not consider it to be hardy. I have not heard of its being cultivated in America.

Rhododendron Weyrichii Maximowicz in Mém. Acad. Sci. St. Pétersbourg, sér. 7, XVI. No. 9, 26, t. 2, fig. 1-6 (Rhodod. As. Or.) (1870). - Franchet \& Savatier, Enum. Pl. Jap. I. 288 (1875).Makino in Tokyo Bot. Mag. XVIII. 48 (1904). - Schneider, Ill. Handb. Laubholzk. II. 495 (1909), in a note. - Matsumura, Ind. Pl. Jap. II. pt. 2, 464 (1912). - Nakai, Rep. Fl. Quelpaert Isl. No. 999 (1915); in Tokyo Bot. Mag. XXXI. 243 (1917); Fl. Syl. Kor. VIII. 44, t. 16 (1919). - Millais, Rhodod. 261 (1917), excluding the Chinese plant. - Komatsu in Tokyo Bot. Mag. XXXII. [10] (1918).

Azalea Weyrichii O. Kuntze, Rev. Gen. pt. 2, 387 (1891).

Rhododendron shikokianum Makino in Tokyo Bot. Mag. VI. 43 (1892); in IX. 111 (1895).

Japan: Shikoku, prov. Tosa, round Kochi, sea-level to $800 \mathrm{~m}$. altitude, November 17, 1914, E. H. Wilson (No. 7813). Kyushu, prov. Hizen, near Nagasaki, 1862, R. Oldham (No. 511, Herb. Gray).

Korea: Quelpaert Island, between Saishu and the Monastery, 400-650 m. October 30, 1917, E. H. Wilson (No. 9411); same island, Hallai-san, October, 1906, May, 1907, U. Faurie (Nos. 661, 1863 in part, 1864); same place, May, 1909, April 14, June 6, 1908, E. Taquet (Nos. 2970, 4678, 1089). 
This little known species has a very curious distribution. On the island of Shikoku it is common round Kochi in Tosa province but does not grow on the mainland of Kyushu, but it is found on the adjacent islands of Amakusa and Goto south and west of Nagasaki. I do not know whether it grows on the island of Tsushima in the Japan Sea - probably it does - but it is common on the Korean island of Quelpaert although unknown on the mainland of Korea. In Shikoku I found it to be fairly plentiful from near sea-level up to an altitude of $800 \mathrm{~m}$. growing in thickets and open woods. On Hallai-san, an extinct volcano on Quelpaert Island, between 200 and $1000 \mathrm{~m}$. altitude, and especially in thickets by the sides of water-courses and on old lava flows, it is common.

This Azalea is a vigorous growing shrub from 1 to $5 \mathrm{~m}$. tall, of ten decidedly tree-like in habit, with moderately stout ascending to spreading often whorled branches. These are yellow-brown, clothed with ferrugineous tomentum when young, becoming glabrous, gray and finally dark purple in color. The winter-buds are characteristic, being conic and sub-acute and clothed with yellow-brown, matted and straight hairs and are unlike those of other species. The leaves are distinctly petiolate, chartaceous, shining green and deciduous, changing to vinous purple in the autumn; on the vigorous shoots the leaves are scattered and in pairs or whorls but on the branchlets they are clustered in whorls of 3 , or in pairs; they vary from broad-ovate to semiorbicular or to rhombic, and in size from 3.5 to $8 \mathrm{~cm}$. long and from 2 to $6 \mathrm{~cm}$. wide; they are abruptly subacute or obtuse at the apex which is mucronate, the base is broadly cuneate or rounded. The principal veins are impressed above and slightly raised on the lower surface which is venulose. When young the petioles and both surfaces of the leaf are covered with rufous-brown pilose hairs but these soon disappear. The flowers are from 2 to 4 in terminal umbels, and open before or at the same time as the leaves unfold. The pedicels, calyx and ovary are densely clad with rufous-brown pilose hairs. The corolla is red, almost brick-red, from 3.5 to $6 \mathrm{~cm}$. across, funnelshape, with a rather narrow expanding tube and spreading lobes. The calyx is merely a ring with five minute teeth. The stamens vary from 6 to 10 , and are of unequal length, and like the curved style and its capitate stigma are included. The fruit is cylindric or oblong-ovoid, from 1.5 to $2 \mathrm{~cm}$. long, oblique, furrowed and obtusely angled and clothed with appressed, villose pubescence. This species was discovered on the Goto Islands in 1853 by Dr. Heinrich Weyrich, a surgeon on the Russian warship "Vostok" which formed part of Admiral Putiatin's fleet. On Oldham's specimen the locality cited is Nagasaki but this is a mistake; it probably came from the Amakusa Islands south by west of that city. Makino first found it in Shikoku and Père Faurie on Quelpaert Island. It was unknown in gardens until 1914 when I sent the seeds from Shikoku to the Arnold Arboretum which were distributed in America and Europe. Plants raised in this Arboretum have not proved hardy but in another Massachusetts garden where they have received the protection of a cold frame they have flowered. In 1917 I collected seeds on Quelpaert and hope that they will produce a hardier type. I have never seen this Rhododendron in flower in a wild state and only a late flower or two on cultivated plants. The color of the flowers is good and where it proves hardy this species should be a welcome addition to gardens.

Rhododendron reticulatum D. Don apud G. Don, Gen. Syst. III. 846 (1834). - De Candolle, Prodr. VII. pt. 2, 727 (1839).

Rhododendron dilatatum Miquel in Ann. Mus. Lugd.-Bat. I. 34 (1863-64); in II. 164 (1865-66); Prol. Fl. Jap. 96 (1866-67).

Rhododendron rhombicum Miquel in Ann. Mus. Lugd.-Bat. II. 164 (1865-66); Prol. Fl. Jap. 96 (1866-67). - Regel in Gartenfl. X. XVII. 225, t. 586 
(1868). - Maximowicz in Mém. Acad. Sci. St. Pétersbourg, sér. 7 XVI. No. 9, 26 (Rhod. As. Or.) (1870). - Franchet \& Savatier, Enum. Pl. Jap. I. 288. (1875). - Hooker f. in Bot. Mag. CXIII. t. 6972 (1887). - Bean in Gard. Chron. ser. 3, XX. 38, fig. 9 (1896); Trees and Shrubs Brit. Isl. II. 375, fig. (1914). - Boissier in Bull. Herb. Boiss. V. 918 (1897). - Dallimore in Garden, LXXII. 267, fig. (1908). - Mottet in Rev. Hort. 1909, 79, fig. 28. - Schneider, Ill. Handb. Laubholzk. II. 497, figs. 327 f-g, $328 \mathrm{~d}-\mathrm{e}$ (1911). - W. Watson, Rhodod. and Azaleas, 111 (1911). - Matsumura, Ind. Pl. Jap. II. pt. 2, 463. (1912). - Rehder in Bailey, Stand. Cycl. Hort. V. 2943 (1916). - Millais, Rhodod. 235 (1917). - Komatsu in Tokyo Bot. Mag. XXXII. [10] (1918).

Azalea reticulata $\mathbf{K}$. Koch, Dendr. II. pt. 1, 179 (1872).

Azalea dilatata O. Kuntze, Rev. Gen. pt. 2, 387 (1891).

Azalea rhombica O. Kuntze, Ret. Gen. pt. 2, 387 (1891). - Rehder in Bailey, Cycl. Am. Hort. I. 122 (1900).

Rhododendron dilatatum $\beta$. decandrum Makino in Tokyo Bot. Mag. VII. 134 (1893).

Rhododendron decandrum Makino in Jour. Jap. Bot. I. 21 (1917).

Rhododendron Wadanum Makino in Jour. Jap. Bot. I. 21 (1917).

Japan: Kyushu, prov. Satsuma, Kagoshima in gardens, March 4, 1914, E. H. Wilson (No. 6158); Togo, in a garden, March 14, 1914, E. H. Wilson (No.6266); prov. Osumi, Mt. Kirishima, alt. 100-1000 m. 1917, Z. Tashiro; Nishi-Kirishima, alt. $1000 \mathrm{~m}$. March 11, 1914, E. H. Wilson (No. 6241); prov. Hizen, Nagasaki, Mt. Yuwaja, 1863, C. Maximowicz (Herb. Gray). Shikoku, prov. Tosa, Nano-kawa, May 12, 1889, K. Watanabe (Herb. Gray). Hondo, prov. Choshu, between Habu and Asa, May 7, 1918, E. H. Wilson (No. 10,369); prov. Aki, Miyajima, November 28, 1914, E. H. Wilson (No. 7842); prov. Yamato, Yoshino, April 22, 1914, E. H. Wilson (No. 6573); prov. Yamashiro, Kyoto, April 22, 1914, E. H. Wilson (No. 6568); prov. Shinano, Ogawa, September 5, 1905, J. G. Jack; Nojiri to Nakatsugawa, September 6, 1905, J. G. Jack; slopes of Mt. Komaga-take, October 24, 1892, C. S. Sargent; prov. Suruga, lower slopes of Mt. Fuji, alt. 800-1000 m. May 8, 1914, E. H. Wilson (No. 6640); prov. Sagami, Hakone Mts. Kintoki, May, 1876, James Bissett (No. 237, Herb. Kew); prov. Shimotsuke, Nikko region, alt. 1000-1800 m. May 18, October 24, 1914, E. H. Wilson (Nos. 6705, 7694), shores of Lake Chuzenji, September 3, November 7, 1892, C. S. Sargent; same locality, October 25, 1905, J. G. Jack. Hokkaido, prov. Hidaka, Shoya village, August 17, E. Tolubuchi. Province unknown, "Mimasaka," May 10, 1904, S. Arimoto (Herb. Gray).

Cultivated: Arnold Arboretum (No. 3427-1).

This is a common plant throughout the greater part of Japan. In Kyushu, Shikoku and Hondo it is everywhere abundant; in Hokkaido it is rather rare and 
finds the northern limits of its range in Hidaka province. On volcanic ash, Iavaflows and on cliffs in many places, as in the Nikko region, lower slopes of Mt. Fuji and on the Hakone mountains for example, it is extraordinarily abundant both in open country, in thickets, on the margins of woods and as undergrowth in thin forests. It is in flower from early in March to late in June according to latitude and altitude and produces in great abundance its rose- to red-purple or rich magenta-colored blossoms. The richest colors are on plants in the open, and in dense shade the color is quite pale. Nowadays magenta is not a popular color in the west but massed and alone save for the varying shades of green the flowers of this Azalea are impressive. The plant forms a much-branched bush or bushy tree from 1 to 8 metres tall, with numerous erect or erect-spreading verticillate, slender but rigid branches, yellow-brown and sparsely or densely hairy when young, usually soon becoming glabrous, and in the second year pale gray. In the shade the branches are more sparse and the plants less compact and shapely in habit. The winter-buds are conic and acute, with rufous- or gray-brown, villose and ciliate scales, the inner ones being viscid. The leaves unfold as the corollas fall, and are clustered in threes or in pairs at the end of the branchlets, and vary in shape from broad-ovate to rhombic or occasionally to ovate, and terminate in a short mucro. In size they vary from 3 to $6 \mathrm{~cm}$. in length and from 2.5 to 5.5 . $\mathrm{cm}$. in width, with petioles from 0.5 to $1.5 \mathrm{long}$. In the shade the leaves are membranous but in the open they are firm and the reticulation is more prominent; they are dark green above, pale even sub-glaucous below, and in the autumn change to vinous or blackish purple or occasionally to yellow with splashes of red-purple. The principal veins are impressed above and raised and usually more or less villose on the under surface. When young the leaves are densely clothed with long, or with short and long, appressed, gray to yellow-brown pilose hairs which disappear early from the upper and entirely or partially from the lower surface. The petiole is flattened and usually villose, but may be glabrous and glaucescent. The flowers are borne at the end of the shoots in pairs or solitary or in clusters of three or four. The corolla is from 3.5 to $5 \mathrm{~cm}$. across usually unspotted, with a short tube and spreading lobes which are of ten divergent and give the corolla a two-lipped appearance. The pedicels are clothed with gray or brownish appressed hairs, and the minute, 5-toothed calyx is ciliate, villose or glabrescent. The stamens are normally 10, in two series, the longer equalling the corolla in length, the shorter half as long, the filaments curving upward; the anthers are purple. The ovary is covered with short straight hairs, or is lepidote, or lepidote and hairy, and the style is hairy or glabrous; the stigma capitate and minutely 5-lobed. The fruit is curved, cylindric, from 1 to $1.5 \mathrm{~cm}$. long, furrowed, lepidote, glabrous, or clothed with gray or brown soft hairs.

I have gone very minutely into the degree of variation exhibited by this plant for I realize that those who compare the two figures in the Botanical Magazine will find it difficult to appreciate that they represent the same species and really only differ in the number of stamens. In the array of specimens before me and cited above the variations mentioned are all shown and neither among them nor in the field have I been able to distinguish two species. The distinguishing characters emphasized by Maximowicz are inconstant except the number of stamens and I am doubtful if careful examination among many plants would not reveal flowers with five and others with ten stamens on the same plant. I have 10stamened flowers with a lepidote ovary and style, with a hirsute and lepidote ovary and glabrous style; I have 5-stamened flowers which show exactly the same variation. On both forms I find glabrous leaves and leaves more or less pubescent below especially on the principal veins.

Miquel had only leaf specimens and founded his two species chiefly on the difference in shape of the leaves. On every plant of this species as here understood 
the leaves tend toward a rhombic shape, in fact this predominates and from this they vary to broad-ovate and occasionally to ovate. An attempt to make leafdistinetions in this plant of specific value breaks down on the first bush examined. Maximowicz who had flowering specimens and young leaves added to Miquel's description of $R$. dilatatum the 5 stamens and glandular ovary which subsequent authors have used to distinguish Miquel's two species. That Maximowicz was not justified in this is abundantly proved by the material before me. As to Makino's $R$. Wadanum I have specimens from Shikoku with slightly spotted flowers but can find no other difference and do not consider that they can be separated even as a variety. It is unfortunate that both Miquel's names should have to be dropped but G. Don's description, brief as it is, leaves no doubt that the plant he had was the same as that later described by Miquel. It has long been accepted that Don's name belonged to one of Miquel's species but the question remained to which? With the acceptance of the view first suggested by $\mathbf{K}$. Koch that both represent one species the question disappears and Don's name becomes the valid, as it is the oldest, name. I have taken the form with ten stamens as representing the type since it is by far the more common.

According to G. Don this Azalea was first introduced into England from Japan by Messers Knight of Chelsea and evidently about 1832-33, but it must have been lost. It was introduced by Maximowicz into the Petrograd Botanic Gardens in 1865, and is figured in the Gartenflora for 1868 but the color is poor. It was introduced into the Arnold Arboretum by Professor Sargent who sent seeds from the Nikko region in the autumn of 1892 . The plants have grown slowly but have proved perfectly hardy and each spring for a number of years past have flowered profusely. Apparently it is rare in Europe and is one of the plants which will probably thrive better in eastern North America than in England.

The specimen cited from Kintoki on the Hakone mountains is simply an abnormal condition of typical $R$. reticulatum $G$. Don in which the flowers have been retarded and are open when the leaves are well grown. There are two flowers and the pistil of a third, and a small deformed flower on the specimen, and one flower with two unfolding leaves. The leaves have the characteristic rhombic shape and the flowers have from 8 to 10 stamens. Branches bearing late flowers and leaves together may be found occasionally on any species of precocious flowering Rhododendron.

A variety with white flowers is: -

Rhododendron reticulatum var. albiflorum Wilson, n. comb.

Rhododendron rhombicum var. albiflorum Makino in Tokyo Bot. Mag. XVIII. 66 (1904). - Rehder in Bailey, Stand. Cycl. Hort. V. 2943 (1916).

Makino describes this plant from Tosa province in Shikoku and states that it is very rare. It is unknown to me and is not cultivated in western gardens.

The form adopted by Maximowicz as the typical $R$. dilatatum Miquel, and so considered by subsequent authors, and which is characterised by having 5 stamens only may be distinguished as: -

\section{Rhododendron reticulatum $\mathrm{f}$. pentandrum Wilson, n. nom.}

Rhododendron dilatatum Maximowicz in Mém. Acad. Sci. St. Pétersbourg, sér. 7, XVI. No. 9, 27 (Rhodod. As. Or.) (1870), in part, not Miquel. Franchet \& Savatier, Enum. Pl. Jap. I. 289 (1875). - Matsumura, Pl. Nikko 71 (1894); Ind. Pl. Jap. II. pt. 2, 459 (1912). - Boissier in Bull. 
Herb. Boiss. V. 918 (1897), - Hooker f. in Bot. Mag. CXXV. t. 7681 (1899). J. H. Veitch, Hortus Veitchii, 373 (1906). 一 Shirisawa, Icon. Ess. For. Jap. II. t. 61, figs. 23-32 (1908). — Schneider, Ill. Handb. Laubholzk. II. 497, figs. 327 h, 328 a-b (1911). - Bean, Trees and Shrubs Brit. Isl. II. 353 (1914). - Millais, Rhodod. 155 (1917). - Komatsu in Tokyo Bot. Mag. XXX11. [9] (1918).

Rhododendron dilatatum a. typicum Makino in Tokyo Bot. Mag. VIl. 134(1893).

Japan: Hondo, prov. Shinano, 1864, Tschonoski (Herb. Gray); prov. Suruga, Mt. Fuji, May 12, 1907, (flowers), August 15, 1905, (leaves); prov. Sagami, Hakone Mts., alt. 600-1000 m. April 16, 1914, E. H. Wilson (No. 6448); in a garden, Miyanoshita, April 17, 1914, E. H. Wilson (No. 6429).

Cultivated: Royal Gardens, Kew, May, 1880, G. Nicholson.

Of the characters proposed by Maximowicz only that of the 5 stamens seems to hold and, as I have already mentioned, I am not convinced that this is constant. This form is believed to have been introduced to England by Messers Veitch in 1883 , but that it was in cultivation in Kew as early as 1880 is shown by Nicholson's specimens preserved in this herbarium. I have no record of its being cultivated in America though it will probably appear among the seedlings raised from Japanese seeds collected by me in 1914 and distributed by the Arnold Arboretum.

Rhododendron quinquefolium Bisset \& Moore in Jour. Bot. XV 292 (1877). — Franchet \& Savatier, Enum. Pl. Jap. II. 653 (1879). Matsumura, Pl. Nikko, 71 (1894); in Tokyo Bot. Mag. XIV. 69 (1900); Ind. Pl. Jap. II. pt. 2, 463 (1912). - Komatsu in Icon. Pl. Koisikav. I. 59, t. 30 (1912); in Tokyo Bot. Mag. XXXII. [8] (1918). Bean, Trees and Shrubs Brit. Isl. II. 374 (1914). - Rehder in Bailey, Stand. Cycl. Hort. V. 2947 (1916). - Millais, Rhodod. 233 (1917).

Japan: Hondo, prov. Shimotsuke, Nikko region, alt. 600-1600 m. May 14, May 18, October 20,1914, E. H. Wilson (No. 6683, type, 6683A, 7676); Lake Chuzenji, October 21, 1914, E. H. Wilson (No. 7676A); same locality, August 11, October 25, 1905, J. G. Jack.

This very distinct species is well characterised by its corky, brown bark, its broad-elliptic to obovate verticillate leaves and by its snow white, rotate-campanulate corolla. In habit of growth, arrangement and shape of leaves and in the shape of the flowers it superficially resembles $R$. pentaphyllum Maxim. but the two belong to different sections. In Maximowicz's species the flowers and leafy shoots originate from different buds, the flower-bud being terminal and the leaf-buds lateral below it. In this new species both flowers and leafy shoots issue from the same bud. This Azalea is abundant in shady, rocky ravines in the Nikko region but is elsewhere unknown to me. It is a bush or small tree from 1.5 to $8 \mathrm{~m}$. tall with gray-brown, corky bark, fissured into thick irregular plates; the shoots are glabrous, terete, shining brown the first year and arranged partly in verticils and partly alternate. The winter-buds are narrow-ovoid, acute, with 
purple-brown ciliate scales, the basal ones having long aristate points. The leaves are deciduous and unfold at the same time as the flowers open; they are clustered 4 or 5 together at the end of the shoots and vary from broad-elliptic to obovate, the apex is mucronate and the base cuneate, the edges are ciliate and of ten margined with red-purple; they are more or less villose, especially the lower half of the midrib; the petiole is very short and villose. The flowers are either solitary, or two or three together on slender, glandular-hairy pedicels; the corolla is pure white with green spots within, rotate-campanulate, and the calyx is membranous, with 5 lanceolate or deltoid, glandular-ciliolate segments. The stamens are ten, with greenish filaments of unequal length, dilated and villose at the base. The pistil much exceeds the stamens and is glabrous except at the summit of the ovary. The fruit is stout, cylindric, and from 1 to $1.5 \mathrm{~cm}$. long.

According to Bean, this Azalea was introduced into English gardens by Lord Redesdale about 1896, but it appears to be rare in gardens. To America it has been sent by the Yokohama Nursery Company under the name of "Azalea quinquefolia white" and I have seen it growing fairly well in the garden of Mr. T. A. Havemeyer, on Long Island. It is a woodland plant and needs shade and a cool situation if it is to thrive. In $1905 \mathrm{Mr}$. J. G. Jack sent seeds from Lake Chuzenji to this Arboretum but the resultant plants failed to prove hardy. The plants raised from seeds sent from the same locality in 1914 have also proved tender. Like many other woodland plants this Azalea is difficult to manage when young.

Rhododendron Schlippenbachii Maximowicz in Bull. Acad. Sci. St. Pétersbourg, sér. 3, XV. 226 (Mél. Biol. VII, 333) (1870); in Mém. Acad. Sci. St. Pétersbourg, sér. 7, XVI. No. 9, 29, t. 2, figs. 7-13 (Rhodod. As. Or.) (1870). - Herder in Act. Hort. Petrop. I. 347 (1871). Franchet \& Savatier, Enum. Pl. Jap. 289 (1875). - Hemsley in Jour. Linn. Soc. XXVI. 30 (1889). - Hooker f. in Bot. Mag. CXX. t. 7373 (1894). - Gard. Chron. ser. 3, XV. 462, fig. 58 (1894); XIX. 561, fig. 87 (1896); LV. 9, t. (1914). - W. Watson in Garden XLVI. 80, t. 972 (1894); Rhodod. and Azaleas, 112 (1911). - Palibin in Act. Hort. Petrop. XVIII. 150 (Consp. Fl. Kor. II.) (1900). - J. H. Veitch, Hortus Veitchii, 408 (1906). - Komarov in Act. Hort. Petrop. XXIV. 206 (Fl. Mandsh. III.) (1907). - Schneider, Ill. Handb. Laubholzk. II. 494, figs. 325 i-l 327 a-b (1909). - Nakai in Jour. Coll. Sci. Tokyo, XXXI. 75 (Fl. Kor. pt. 2) (1911); Fl. Syl. Kor. VIII. 43, t. 15 (1919). - Matsumura, Ind. Pl. Jap. II. pt. 2, 464 (1912). W. Taylor in Garden, LXXVII. 136, fig. (1913). - Bean, Trees and Shrubs Brit. Isl. II. 378 (1914). - Rehder in Bailey, Stand. Cycl. Hort. V. 2943 (1916). - Millais, Rhodod. 239 (1917). - Komatsu in Tokyo Bot. Mag. XXXII. [9] (1918).

Azalea Schlippenbachii O. Kuntze, Rev. Gen. pt. 2, 387 (1891).

Korea: prov. South Keisho, Herschel Island, 1863, R. Oldham (No. 510, Herb. Gray); Chirisan, alt. 600-1845 m. November 16, 
1917, E. H. Wilson (No. 9592); Fusan, September 11; 1905, J. G. Jack; prov. Keiki, East Park palace, Seoul, September 24, 1905, J. G. Jack; Government Forestry Garden, Seoul, cultivated, May 21, 1917, E. H. Wilson (No. 8431); Kazan, near Suigen, May 24, 1917, E. H. Wilson (No. 8472); prov. Kōgen, Diamond Mts., July 7, 1918, E. H. Wilson (No. 10,493); prov. South Kankyo, hills round Gensan (Wonsan), September 5, 1903, C. S. Sargent; between Shinkori and Eiko, September 20, 23, 1917, E. H. Wilson (Nos. 9201, 9223); prov. North Heian, altitude 300-1000 m. June 16, 1917, E. H. Wilson (No. 8603); province unknown, "Pomasa," altitude $800 \mathrm{~m}$. May 21, 1906, U. Faurie (No. 665); "Hoangheito," August, 1906, U. Faurie (No.668); northeast coast, 1854, Baron A. Schlippenbach (Herb. Gray). Northeast Manchuria: shores of Possiet Bay, 1860, C. Maximowicz (Herb. Gray).

Japan: Hondo, prov. Ugo, Chokai-san, June 15, 1903, K. Sakurai. Cultivated: Arnold Arboretum (No. 7258).

This is one of the commonest shrubs in Korea and in thin woods is of ten the dominant undergrowth. It just crosses the border into northeast Manchuria on the shores of Possiet Bay and in Japan.is known from only two localities in north Hondo. In Korea the southern limit of its range appears to be the Chiri-san range, and Herschel Island in about the same latitude. Curiously it does not grow on Quelpaert Island where the representative species is $R$. Weyrichii Maxim. On the lower-middle slopes of Chiri-san and the lower slopes of the Diamond Mountains $\boldsymbol{R}$. Schlippenbachii is extraordinarily abundant. In June these regions are a wonderful sight with literally miles and miles of the purest pink from the millions of flowers of this Azalea. The plant grows from 1 to $5 \mathrm{~m}$. tall and in open places is sturdy and densely branched but in shade the branching is lax. The branches are rigid, erect, verticillate or irregular, covered with curled glandular haire when young; pale brown the first year, becoming gray and glabrous the second. The leaves are deciduous, thin, clustered in whorls of five at the end of the branches; on strong shoots the whorl may be subtended by a pair of leaves and these by odd, scattered leaves of small size; in shape they are all uniform being more or less obovate (often broadly so), from 5 to $9 \mathrm{~cm}$. long and from 3 to $7 \mathrm{~cm}$. wide, the apex is truncate or rounded, emarginate, with a glandular mucro, and the base is narrowed to a short, broad petiole; the margins are slightly undulate, and both surfaces are at first sparsely pubescent but later are glabrous except on the underside of the principal nerves. The leaves are dark green above, pale below and in autumn change to yellow, orange and crimson. The flowers are fragrant, borne in terminal 3- to 6-flowered umbellate clusters, and usually open as the leaves begin to unfold. The corolla is pale- to rose-pink, broad-rotate, funnel-shape, from 6 to $8 \mathrm{~cm}$. in diameter, with spreading, rounded lobes, the posterior marked with red-brown spots. The pedicels and calyx are elothed with glandular hairs, and the calyx-lobes are green, ovoid, about $5 \mathrm{~mm}$. long and persistent. The stamens, always 10 in number, are of unequal length, the longest equalling the corolla but shorter than the style. The fruit is erect, oblong-ovoid, about $1.5 \mathrm{~cm}$. long, slightly oblique and covered with sessile glands; the seeds are angular, shining dark brown. 
This species was discovered by Baron A. von Schlippenbach of the Russian navy on the shores of northeast Korea in 1854, and appears to have been cultivated sparingly in Japan for many years under the name of "Kurofune-tsutsuji." James H. Veitch in 1893 saw it in a garden in Japan and sent it to England and this was its first appearance in the west. Since then Japanese nurserymen have exported it in small quantities to Europe and America but to this time it is by no means so well known as its beauty warrants. The plants in this Arboretum were raised from seeds collected in Korea in 1905 by Mr. J. G. Jack; they have grown slowly but have been unaffected by winter-cold and summer-drought. For two to three years past they have flowered freely and their large, pure pink blossoms are lovely. This species has the second largest leaves and the most beautiful flowers of its group and is worthy of a place in every garden. I collected a quantity of seed in Korea in the autumns of 1917 and 1918, and this has been widely distributed by the Arnold Arboretum and in a few years this Azales should be a prominent feature in New England gardens. 


\section{SECT. III. RHODORA G. DON ${ }^{2}$}

Flowers from a terminal bud, the leafy shoots arising from separate, lower, lateral buds; corolla rotate-campanulate, rarely campanulate or two-lipped; stamens 10, rarely from 5 to 7 . Leaves deciduous, scattered or whorled. Fruit more or less cylindric, rarely conic-ovoid. Shrubs often of large size, usually with rigid ascending or spreading branches; shoots glabrous or hairy.

This section contains 5 species; three of these grow in eastern Asia and two (R. canadense Zabel and $R$. Vaseyi A. Gray) in eastern North America.

Rhododendron Albrechtii Maximowicz in Bull. Acad. Sci. St. Pétersbourg, sér. 3, XV. 227 (Mél. Biol. VII. 335) (1870); in Mém. Acad. Sci. St. Pétersbourg, sér. 7. XVI. No. 9, 30, t. 2, figs. 14-20 (Rhodod. As. Or.) (1870). - Franchet \& Savatier, Enum. Pl. Jap. I. 290 (1875). - Matsumura, Pl. Nikko, 71 (1894); Ind. Pl. Jap. II. pt. 2, 458 (1912). - Boissier in Bull. Herb. Boiss. V. 917 (1897). - Schneider, Ill. Handb. Laubholzk. II. 496, figs. $325 \mathrm{~m}-\mathrm{n}, 327 \mathrm{e} \mathrm{(1909).-}$ Millais, Rhodod. 112 (1917). - Komatsu in Tokyo Bot. Mag. XXXII. [8] (1918).

Azalea Albrechtii O. Kuntze, Rev. Gen. pt. 2, 387 (1892). - Rehder in Bailey, Cycl. Am. Hort. I. 122 (1900).

Japan: Hondo, prov. Shinano, 1864, Tschonoski (Herb. Gray); prov. Musashi, cultivated, Bot. Gard. Tokyo, April 2, 1914, E. H. Wilson (No. 6363); prov. Shimotsuke, Nikko region, alt. 1600-2000 m., June 23, October 15, 1914, E. H. Wilson (Nos. 6858, 7638); prov. Uzen, lower slopes of Adzuma-san, alt. 800-1100 m., July 19, October 24, 1914, E. H. Wilson (Nos. 7208, 7721); prov. Mutsu, Hirosaki, May, 1905, U. Faurie (No. 6785); Hakkoda-yama, alt. 1000-1600 m., July 5, 1914, E. H. Wilson (No. 7083); same locality, October 2, 1892, C. S. Sargent. Hokkaido, prov. Oshima, Fuku-yama, June 3, 1889, U. Faurie (No. 3831, Herb. Kew); Kakumi Hot Springs, September 29, 1892, C. S. Sargent; prov. Iburi, Nobori-betsu, July 2, 1914, E. H. Wilson; prov. Ishikari, Sapporo, May 17, October 10, 1903, S. Arimoto (Herb. Gray); same locality, May 29, 1890, E. Tokubuchi (Herb. Gray); Moiwa-dake, June 15, 1885, K. Miyabe (Herb. Gray); same locality, June 23, 1891, E. Tokubuchi; cultivated, Bot. Gard. Sapporo, August 22, 1905, J. G. Jack.

- For synonyms and further details see page 119 . 
On the margin of forests and in thickets this species is widely distributed in northern Japan from the mountains round Sapporo in central Hokkaido southward to those of Shinano in central Hondo. I am familiar with it from the Nikko region northward, but do not consider it a common plant. It is scattered here and there and is partial to dense thickets on steep slopes of loose soil. It is a shrub of loose and sparse habit, from 1 to $1.5 \mathrm{~m}$. tall, with slender, smooth, purplebrown branches which are brown and furnished when young with curled, partly viscid, gray hairs. The leaves are deciduous, membranous, dark green and change to yellow before they fall; they are scattered on the vigorous shoots, and crowded, forming false whorls of fives, at the end of the branchlets; they are obovate to oblanceolate, from 4 to $12 \mathrm{~cm}$. long and from 1.5 to $6 \mathrm{~cm}$. wide, acute or subacute, with a glandular mucro; the base is narrowed to a short, winged petiole; the margins are serrulate and ciliate, the upper surface is sparsely clad with appressed, flattened, hispid hairs and the under surface is more or less densely clothed with short, pale gray tomentum. The flowers are about $5 \mathrm{~cm}$. across, and open in June and early July, according to climate, and immediately before or as the leaves unfold; they are borne in terminal umbels, each containing from 3 to 5 flowers. The pedicels are moderately stout, from 1 to $2 \mathrm{~cm}$. long, and are clothed with curled, glandular, yellowish hairs; the calyx is small, with 5 purple and ciliate lobes; the corolla is rich red-purple, rotate-campanulate, with a short, wide tube and spreading, rounded lobes; the stamens are 10 in number in two series of unequal length, the longest equalling the corolla and overtopped by the curved style, which has a bifid stigma. The fruit is erect, conio ovoid, from 1 to $1.2 \mathrm{~cm}$. long, purple-brown, and clothed with yellow, viscid, pilose hairs.

This species was discovered about 1860 by Dr. Michael Albrecht of the Rusaian Consulate in Hakodate, and was found by Maximowicz also in the vicinity of Hakodate in 1861. However, it does not appear to have been introduced into western gardens until 1892, when Professor Sargent sent seeds to the Arnold Arboretum from two localities in Hokkaido. Plants raised from these seeds grew for several years in this Arboretum, but never really flourished. I sent seeds from northern Hondo in 1914, and these were distributed by the Arboretum. Plants raised from these seeds have grown fairly well, but it is too early to say whether they will make themselves at home here. There is no apparent reason why this Azalea should not thrive here. The habit is sparse and the flowers are not large, but the color is intense and the plant is graceful and attractive.

Rhododendron pentaphyllum Maximowicz in Bull. Acad. Sci. St. Pétersbourg, sér. 3, XXXI. 65 (Mél. Biol. XII. 491) (1887).-Matsumura, Ind. Pl. Jap. II. pt. 2, 463 (1912). - Millais, Rhodod. 225 (1917). - Komatsu in Tokyo Bot. Mag. XXXII. [8] (1918).

Rhododendron pentaphyllum var. nikoense Komatsu in Icon. Pl. Koisikav. III. 45, t. 168 (1916).

Rhododendron quinquefolium var. roseum Rehder in Bailey, Stand. Cycl. Hort. V. 2947 (1916).

Japan: Kyushu, prov. Osumi, Tarumizu village, April and May, 1911, S. Kawagoe. Hondo, prov. Kozuki, Mt. Akagi, June 13, 1911, as to flowers, May 17, 1921, K. Sakurai; prov. Musashi, Yokohama, cultivated, April 11, 1914, E. H. Wilson (No. 6396); prov. Shimot- 
suki, Nikko region, alt. 1000-2000 m., May 18, May 25, May 31, October 20, 1914, E. H. Wilson (Nos. 6698, 7683); same region, shores of Lake Chuzenji, November, 1892, C. S. Sargent.

Cultivated: Hort. T. A. Havemeyer, Glenhead, Long Island, New York, April 23, 1919.

This species is distributed in Japan from the extreme south of Kyushu through Shikoku and Hondo to the Nikko region and beyond to Adzuma-san in Iwashiro province but is nowhere abundant. I have seen it wild in the Nikko region only and there, near the Hashimoto Tea House and on the mountain behind the Lakeside Hotel at Chuzenji, it is common. It grows chiefly among deciduous trees and shrubs and, flowering early, its pure rose-pink blossoms are conspicuous from a long distance. My first view of it was across a deep ravine and I shall never forget the charm of that splash of lovely color among the leafless plants of a well-wooded steep slope. This Azalea is a large bush or small tree from 2 to $8 \mathrm{~m}$. tall, with a dense crown of twiggy ascending and spreading branches which are arranged partly in verticils and partly in an alternate manner, and are sparsely pilose when young but soon become glabrous; they are red-brown and more or less angular the first year, later terete and gray. The trunk is clothed with pale graybrown bark. The winter-buds are short or elongated, acute, with shining purplish brown, ciliolate, rather paleaceous scales. The leaves are clustered in a whorl of 5 at the end of the branchlet and are deciduous, chartaceous in texture, lustrous green in the summer, changing to rich tints of orange and crimson in the autumn; they are oval to elliptic-lanceolate in shape, from 3 to $6 \mathrm{~cm}$. long and from 1.5 to $3 \mathrm{~cm}$. wide, acute and mucronulate, with a narrowed cuneate base; the margins are ciliate and finely serrulate; they are reticulately veined with the midrib villose on both surfaces, especially along the basal half. The petioles are from 3 to $8 \mathrm{~mm}$. long, usually sparsely bearded and glandular. The flowers are solitary or in pairs at the end of the branchlets, and as the flower-buds expand the bud-scales fall. The corolla is unspotted, bright rose-pink in color, about 4 to $5 \mathrm{~cm}$. in diameter, rotate-campanulate, with spreading, rounded, of ten emarginate lobes. The pedicels are sparsely or densely glandularly pilose or quite glabrous and from 1 to $1.5 \mathrm{~cm}$. long. The calyx is glabrous, membranous, with 5 triangular or deltoid teeth which are ciliate and from 1 to $5 \mathrm{~mm}$. long. The stamens are unequal, 10 in number, included; the base of the filaments is villose and the anthers are yellow. The pistil slightly overtops the stamens and is glabrous. The fruit is apindleshaped, swollen about the middle, about $1.5 \mathrm{~cm}$. Iong and $0.8 \mathrm{~cm}$. wide, verruculose, and subtended by the persistent calyx.

This lovely plant is very rare in gardens and appears to have been introduced to Europe and America by the Yokohama Nursery Company, who list it under the name of "Azalea quinquefolia pink." It is essentially a woodland species, fond of partial shade. Where it grows at Nikko the soil is volcanic ash and lavo overlain with black leaf-mould. I collected seeds in 1914 for the Arnold Arboretum and part of them were distributed. The plants raised in this Arboretum have proved tender and difficult to manage, but older plants given a shady woodland site would probably thrive here as well as they do on Long Island, New York. In Japan its autumn tints are singularly vivid and beautiful.

Rhododendron nipponicum Matsumura in Tokyo Bot. Mag. XIII. 17 (1899); in Icon. Pl. Koisikav. I. 9, t. 5 (1911); Ind. Pl. Jap. II. pt. 2, 463 (1912). - Komatsu in Tokyo Bot. Mag. XXXII. [8] (1918). 
Japan: Hondo, prov. Uzen, near Toge, alt. $1000 \mathrm{~m}$., July 20, October 23, 1914, E. H. Wilson (Nos. 7219, 7191).

This little known Japanese species is confined to the mountains of north-central Hondo. It is very distinct in its flowers and fruit and also in its papery, cinnamonbrown bark which shreds off and leaves polished brown stems and branches. No other species with deciduous leaves has such attractive bark. In habit it forms an upright, bushy shrub from 1 to $2 \mathrm{~m}$. high, with rigid, red-brown branches clothed with pilose and glandular hairs. The winter-buds are pale straw-color tinged with purple, large, ovoid, with ciliate, eglandular bud-scales. The leaves are scattered, sessile, membranous and deciduous; they have appressed, hispid hairs on both surfaces and the margins are ciliate; in shape they are panduriform, from 6 to $18 \mathrm{~cm}$. long and from 3.5 to $8.5 \mathrm{~cm}$. wide, with the apex rounded or truncate, usually emarginate, rarely obtuse, and are narrowed to the base, which is firmly appressed to the stem and of ten has a curious shield-like protuberance continued below the point of insertion; the veins are prominent and reticulate on the under side and many are furnished with strigose hairs. In the autumn the leaves are tinted from orange to crimson. The flowers are small and not conspicuous, and open in late June and July with, or even after, the leaves. They are borne from 6 to 15 together in terminal, umbellate corymbs. The corolla is white, tubular or campanulate, from 1.5 to $2 \mathrm{~cm}$. long and from 0.8 to $1 \mathrm{~cm}$. broad, with 5 short, very slightly spreading lobes. The calyx is small, membranous, with lobes of unequal size, and like the slender pedicel is covered with viscid hairs. The stamens are of unequal length, 10 in number and are included, as is the style, which is straight and slightly thickened below the capitate stigma. The fruit is pendent, oval, from 8 to $10 \mathrm{~mm}$. long, and has thin walls which open to the base and have wavy margins.

This species in foliage suggests $R$. Schlippenbachii Maxim., but otherwise is very distinct. On the hills round Toge, near the base of Adzuma-san, in 1914, I found this species to be common in rather open country. The season of flowering was almost past. In the autumn I gathered seeds for the Arnold Arboretum, which distributed them in America and Europe. The plants raised from these seeds have not yet flowered in the Arboretum. This Azalea was unknown to Japanese nurserymen until I gave plants to the Yokohama Nursery Company in 1914. Its bark and foliage is striking, but the size of the flowers and the manner in which they are hidden by the leaves and young shoots detracts from the plant. As a flowering shrub it is one of the least desirable of Japanese Azaleas. 


\section{SeCt. IV. PENTANTHERA G. Don ${ }^{1}$}

Flowers from a terminal bud, the leafy shoots from separate, lower, lateral buds; corolla funnel-form-campanulate to funnel-form; stamens 5. Leaves deciduous, scattered on the shoots. Fruit more or less cylindric. Shrubs usually with stiff, ascending branches. Shoots villose or glabrous.

This section contains some 15 species and is the most widely distributed of the four sections which we are discussing. Two species grow in eastern Asia, one in Japan and the other in China; one species, $R$. luteum Sweet, grows on the Caucasus, in the Pontus region in Asia Minor and in parts of eastern Europe. The others are confined to North America, where they are widely distributed.

Rhododendron molle G. Don, Gen. Syst. III. 846 (1834).

Azalea mollis Blume, Cat. Gewass. Buitenz. 44 (1823); Bijd. Fl. Ned. Ind. 853 (1825).

Azalea sinensis Loddiges, Bot. Cab. IX. t. 885 (1824). - De Candolle, Prodr. VII.pt. 2, 718 (1839). - Fortune, Wanderings in China, 154 (1847); T'ea Countries of China 154 (1852); Residence among Chinese, 28 (1857); Suringar in Gartenfl. LVII. 505 (1908).

Rhododendron sinense B. flavescens Sweet, Brit. Flow. Gard. ser. 1, III. t. 290 (1829).

Rhododendron sinense Sweet, Brit. Flow. Gard. ser. 1, III. sub. t. 290 (1829). Hovey, Am. Gard. Mag. II. 142, 179 (1836). - Hance in Journ. Bot. XVI. 109 (1878). - Hemsley in Jour. Linn. Soc. XXVI. 30 (1889), as to the Chinese plant. - Suringar in Gartenfl. LVII. 516 (1908). - W. Watson, Rhodod. and Azaleas, 112 (1911), in part. - Schneider, Ill. Handb. Laubholzk. II. 497, figs. 328 g-h, 329 a-b (1911). - Rehder \& Wilson in Sargent, Pl. Wilson. I. 549 (1913). - Bean, Trees and Shrubs Brit. Isl. II. 379 (1914). - Millais, Rhodod. (1917), in part.

Rhododendron sinense a. flammeum Sweet, Brit. Flow. Gard. ser. 1, III. sub. $t$. 290 (1829).

Azalea pontica var. sinensis Lindley in Bot. Reg. XV. t. 1253 (1829), poor figure.

Azalea sinensis a. genuina Maximowicz in Suppl. Ind. Sem. Hort. Petrop. $1869,11$.

China: prov. Hupeh, stony hills and Pine-woods 15 miles below Ichang on right bank of Yangtsze River, alt. 30-300 m., April 24, 1907 (flowers), January 18, 1908 (fruit), E. H. Wilson (No. 800); same locality, A. Henry (No. 268); prov. Hunan, near Changsha, among shrubs, alt. 70-400 m., April 7, 1918, Dr. Handel-Mazzetti (No. 2342); prov. Chekiang, vicinity of Ningpo, 1908, D. MacGregor; near Changhua, rocky banks, alt. 300 m., July 12, 1915, F. N. Meyer (No. 1543);

1 For synonyms and further details see page 124 . 
prov. Kiangsii, Nanking, April 23, 1914, Mary Strong Clemens (4226, Herb. Bur. Sci. Manila).

This species is abundant in eastern China, especially on the mountains of the Chekiang province, and appears to have the western limits of its range on the conglomerate hills a little to the east of the city of Ichang where Henry and I collected it. The plant is evidently common in the neighborhood of Ningpo, where every collector since Fortune has gathered it. It grows among coarse grasses and shrubs and in thin pine-woods. It is a sturdy, sparingly branched shrub from half a metre to a metre and a half high, taller than broad, and has rich goldenyellow flowers produced in large trusses before the leaves unfold. In habit and floral characters in general it closely resembles its Japanese relative ( $R$. japonicum Suring.), but it has a smaller and less bristly calyx, flower-stalks without or with few bristles, stamens as long or longer than the corolla and winter-buds densely clothed with a short, nearly white, velvety pubescence. The leaves of the two species are conspicuously different. Those of the Chinese plant are densely clothed on the lower surface with soft, nearly white, matted pubescence which persists through the life of the leaf; the upper surface is also softly pubescent but much of this disappears before autumn. In late summer and autumn the leaves appear glaucous below on account of the density of the pale gray pubescence. The leares of the Chinese species are also larger, up to $15 \mathrm{~cm}$. long and $5.5 \mathrm{~cm}$. wide, more decidedly oblong-lanceolate, and only occasionally broadest above the middle. Sweet's figure (Brit. Flow. Gard. ser. 1, III. t. 290 [1892]) clearly shows these essential characters, and if it is compared with Regel's figure (Gartenfl. XVI. 299, t. 556 [1867]) of the Japanese species the two plants cannot be confused. Since the two may easily be distinguished by the leaves and other characters, behave differently under cultivation and grow wild in widely separated geographical areas, I consider that they are best kept under separate names without discussing the vexed question of what constitutes a species.

I have not seen this Azalea in Chinese gardens but it must long ago have been grown in those of Canton, Hanchow and Soochow. Loddiges received the plant from China in 1823 and figured it in the Botanical Cabinet, IX. t. 885 (1824). This plant in all probability was brought by some ship of the East India Company from Canton. Others were introduced through the same agency during the succeeding years but the species appears to have been lost, or nearly so, when it was sent to the gardens of the Horticultural Society of London by Robert Fortune in 1845. Fortune found it in gardens at Canton and wild on the hills near Ningpo, and in his books he mentions this Azalea several times. According to Blume (Cat. Gewass. Buitenz. 44 [1823]) it was introduced into gardens in Java before 1823 . Of its first introduction into America I can find no record, but Hovey tells us that it flowered with him, and also in the garden of Mr. J. P. Cushing, Watertown, Mass., in April, 1836. Later it became lost and it was not cultivated in America when in January, 1908, I sent seeds from China to the Arnold Arboretum. Some of these seeds were sent to England, where the species appears again to have been lost. Indeed, in western gardens the pure species never seems to have established itself, and like its Japanese relative soon got lost under a mass of hybrid and seminal forms. In this Arboretum the Chinese Azalea is doubtfully hardy, but it is an excellent pot plant and forces well. This tenderness, which is to be expected when the climate of the region in which it grows is taken into consideration, explains its frequent disappearance from gardens. The habit and fine yellow flowers make it a very decorative garden plant but it lacks stamina. Its great use has been in hybridieing, notably with the Japanese species, from which has sprung a race of hybrids popularly known as "Mollis Azaleas," correctly $\times R$. Kosterianum. 
It is a pity to have to discontinue the use of Sweet's name $R$. sinense in favor of one which has been so much misused, but this cannot be avoided. Blume's description is perfectly good, but this publication seems to have been entirely overlooked, all authors quoting him in his Bijdragen Flora Nederlandsch Indië, which was published two years later. Siebold and Zuccarini in 1846 were the first to apply Blume's name to the Japanese plant and initiated the confusion which has existed ever since.

$\times$ Rhododendron Kosterianum Schneider, Ill. Handb. Laubholzk. II. 499 (1911).

Azalea mollis $\times$ sinensis Pynaert \& van Geert in Rev. Hort. Belg. XVII. 121, fig. 18 (1891); XX, 277, t. (1894). - Rodigas in Tijd. Boomt. 1893, 183, fig. 25. Rhododendron sinense W. Watson, Rhodod. and Azaleas, 77 (1911), in part, not Sweet.

Rhododendron sinense $\times$ R. molle Schneider, Ill. Handb. Laubholzk. II. 499 (1911), as a synonym.

Rhododendron molle Millais, Rhodod. 211 (1917), in part, not G. Don, nor Miquel.

Rhododendron molle $\times$ sinense Millais, Rhodod. 212 (1917).

It appears to be the concensus of opinion that Anthony Koster \& Sons of Boskoop, Holland, began to cross $R$. sinense Sweet and $R$. japonicum Suring. about 1880 and to raise hybrids in commercial quantities. They were closely followed by Anthony Waterer, Knap Hill, Surrey. But apparently neither were the first in this field, for in the Florist and Pomologist for 1875, p. 282, William Tillery writes: "In 1872 I had six varieties of the showy hardy Azalea mollis from M. van Houtte named as follows:- 'Isabelle van Houtte,' dark nankeen color, 'Madame Camille van Langenhone,' white striped with rose and carmine, 'Nonpareil,' white bordered with rose, 'Ebenezer Pyke,' half yellow, 'Centi Striatella' and 'Baroness Rothschild.' I find that all the varieties cross very readily with Azalea sinensis - the yellow and white varieties, and I have many healthy seedlings this year from these crosses." This would appear to be the beginning of the race. The work of these pioneers has been emulated by others in Holland, Belgium and England and the result is a wealth of popular Azaleas with lovely flowers in exquisite shades of color. For indoor decoration they are, in normal times, forced by the million in Europe and America. As garden plants out-of-doors they thrive in many parts of England and Millais is loud in their praise. While hardy in the gardens of New England the plants are usually short lived, lack constitution and are even less satisfactory than the "Gandavensis hybrids." The tender strain derived from the Chinese species (R. molle) is unfortunately too potent, and though the plants struggle along for a few years they are rarely satisfactory and generally at the end of a few years die. It is a pity, for they are beautiful plants. In Horticulture, XXX. 71 (1919), there is described a hybrid ("Miss Louisa Hunnewell") raised in 1913 by Mr. T. D. Hatfield, superintendent of the estate of WaIter Hunnewell, Esq., Wellesley, Mass., which is a cross between the pure species $R$. japonicum Suring. and $R$. molle G. Don obtained from the Arnold Arboretum. It first flowered in 1917, and has an orange-yellow corolla similar to that of "Anthony Koster" but even richer in color; it proved "bud hardy" in the exceptionally severe winters of 1917-18 and 1919-20, and is a free grower. If this new Azalea fulfils expectations it will be a most valuable addition to New England gardens.

Another hybrid is: -

X Rhododendron albicans Waterer apud Zabel in Mitt. Deutsch. 
Dendr. Ges. XI. 30 (1902). - Schneider, Ill. Handb. Laubholzk. II. 499 (1911).

Rhododendron occidentale $\times$ sinense Zabel in Beissner, Schelle \& Zabel, Handb.

Laubholzk-Ben. 380 (1903), as a synonym.

Rhododendron molle $\times$ occidentale Schneider, Ill. Handb. Laubholzk. II. 499 (1911), as a synonym.

Azalea occidentalis "Hybrids" Hort. Wezelenburg, Cat. 9 (1915).

Rhododendron occidentale $\times R$. molle $\times$ "Ghent Azaleas" Millais, Rhodod. 220, fig. (1917).

Many varieties of this hybrid have been raised by Anthony Waterer and by Koster \& Sons, among the best being "Superba," "Graciosa," "Exquisite" and "Magnifica." The parentage is, apparently, very mixed; a majority have large white flowers with the usual yellow blotch characteristic of the flowers of the American species, but some have cream and others yellow flowers with a darker blotch. They flower between early June and mid-July and are very hardy.

In quite recent years $\times R$. Kosterianum has been hybridised with a variety of forms of $\times R$. gandavense and the result is a race with double flowers, for which I propose the name of:-

$X$ Rhododendron mixtum Wilson, $n$. nom.

Azalea rustica flore-pleno Hort. ex Vandervoorde in Rev. Hort. Belg. XIX. 232, t. (1893), not Van Houtte. - Cat. A. Waterer, 10 (1911-12.) - Cal.

Wezelenburg, 10 (1915). - Millais, Rhodod. 213 (1917).

It appears to be safer to give a new name to this race than to risk confusing it with the double-flowered "Gandavensis hybrids" (Azaleas rustique de Gand) first raised by Louis van Houtte, who figures four varieties in Flore des Serres XIX. tt. 2021-2024 (1873), and of which "Graf von Meran," "Narcissiflora" and "Louis A. van Houtte," may be considered types. Typical forms of $\times R$. mixtum are "Murillo" with rose-colored flowers, "Virgile" with yellow flowers, "II Tasso" with red flowers, "Milton" with white flowers, and "Racine" with pale pink flowers. According to Millais (Rhodod. 213 [1917]) there are hybrids raised by Vuylsteke between $R$. molle and Azalea altaclarense. These are unknown to me.

Rhododendron molle G. Don has been crossed with one or more of the broad-leafed Rhododendrons and the oldest of these is: -

$\times$ Rhododendron "Smithii aureum" Paxton, Mag. of Bot. IX. 79, t. and fig. (1842). - Gard. Chron. II. 352 (1842). - Robinson, Fl. and Sylva II. 152, t. (1904). - Bean, Trees and Shrubs Brit. Isl. II. 346 (1914).

Rhododendron "Hardy Seedling" $\times$ Azalea sinensis Paxton, Mag. of Bot. IX.79 (1842.)

"Norbiton hybrids" Hort. ex Masters in Gard. Chron. ser. 3, XIII. 665 (1893).

Rhododendron sinense $\times$ Eurhododendron spec. Zabel in Beissner, Schelle \& Zabel, Handb. Laubholz.-Ben. 379 (1903).

I have given the parentage as set down by Paxton but Robinson says " between a yellow form of the Chinese Azalea and Rhododendron caucasicum, the latter of 
which it resembles in habit." This interesting Azaleodendron was raised by a nurseryman at Norbiton, Surrey, named W. Smith, and exhibited before the Horticultural Society of London in the spring of 1842 . It is not now in cultivation in this Arboretum, not being sufficiently hardy to withstand the winter's cold. A specimen in this herbarium under the name of Rhododendron "Victoria regina" and from an exhibition held by the Massachusetts Horticultural Society on April 19,1889 , evidently belongs here, but whether the name it was exhibited under has any standing I do not know.

Another hybrid between a broad-leaf evergreen Rhododendron and $R$. molle G. Don is:-

$\times$ Rhododendron "broughtonii aureum" Hort. apud W. Watson, Rhodod. and Azaleas 93 (1911). - Osborne in Gard. Chron. ser. 3, LI. 53. fig. 29 (1912). - Bean, Trees and Shrubs Brit. Isl. II. 345, fig. (1914).

Osborne in his account of this plant says it " obtains its name from the village of Broughton in Peebleshire, where it was raised by crossing a yellow Azalea and a seedling evergreen Rhododendron." Both Osborne and Bean regard this as the best of its class. It has been in cultivation in this Arboretum since 1910 but does not thrive. More recently M. G. Vander Meulen has raised hybrids between $R$. molle and the evergreen Rhododendrons "Prince Camille de Rohan" and "Leopard" which he names "Edouard André," "Director Rodigas" and "Dr. Masters." Mr. White of Sunningdale has raised similar hybrids. Millais (Rhodod. 214 [1917]) says that they retain their leaves in winter, and are quite hardy and very floriferous.

Rhododendron japonicum Suringar in Gartenfl. LVII. 516 (1908). Schneider, Ill. Handb. Laubholzk. II. 1046 (1912). - Rehder \& Wilson in Sargent, $P l$. Wilson. I. 549 (1913), in a note. - Rehder in Bailey, Stand. Cycl. Hort. V. 2942 (1916). - Arnold Arb. Bull. Popular Inform. n. ser. III. 26 (1917); IV. 20, 28 (1918). - Komatsu in Tokyo Bot. Mag. XXXII. [6] (1918). - E. G. Loder in Rhodod. Soc. Notes, I. No. 4, 197 (1918).

Rhododendron molle Siebold and Zuccarini in Abh. Akad. Münch. IV. pt. 3, 131 (Fl. Jap. Fam. Nat. II. 7) (1846), not G. Don. - Miquel in Ann. Mus. Lugd.-Bat. I. 33 (1864); II. 164 (1865-66); Prol. Fl. Jap. 96 (1866-67). Schneider, Ill. Handb. Laubholzk. III. 499, figg. 328 i-k, 329 c-d (1911).Bean, Trees and Shrubs Brit. Isl. II. 368 (1914). - Millais, Rhodod. 211 (1917), in part.

Azalea japonica A. Gray in Mem. Am. Acad. n. ser. VI. 400 (1858-59). Hemsley in Garden, XI. 420, t. (1877), in part.

Rhododendron molle var. glabrior Miquel in Ann. Mus. Lugd.-Bat. I. 33 (1864). Azalea mollis $\beta$. glabrior Regel in Gartenfl. XVI. 289, t. 556 (1867). - Van Houtte in Fl. des Serr. XIX. 177 tt. 2034-2035 (1873).

Azalea sinensis $\beta$. glabrior Maximowicz in Suppl. Ind. Sem. Hort. Petrop. (1869) 11.

Rhododendron Sinense Maximowicz in Mém. Acad. Sci. St. Pétersbourg, sér. 7, XVI. No. 9, 28 (Rhodod. As. Or.) (1870), not Sweet.-Hooker f. in 
Bot. Mag. XCVII. t. 5905 (1871). - Franchet \& Savatier, Enum. Pl. Jap. I. 289 (1875). - Matsumura \& Yatabe, Nippon Shokub. 163 (1884). Matsumura, Pl. Nikko, 71 (1894); Shokub. 250 (1895); Ind. Pl. Jap. II. pt. 2, 464 (1912). - Shirasawa, Icon. Ess. For. Jap. II. t. 62, figs. 19-27 (1908). - Hayata, Veget. Mt. Fuji, 66 (1911). - Ito, Icon. Pl. Jap. I. No. 5, 1, t. 17 (1913). - W. Watson, Rhodod. and Azaleas, 112 (1911), in part.

Azalea mollis André in Ill. Hort. XVIII. 132, t. 68 (1871), not Blume.Suringar in Gartenfl. LVII. 505 (1908).

Japan: Hondo, prov. Suruga, Mt. Fuji, alt. 600-1000 m., open country, May 8, 1914, E. H. Witson (No. 6657); same locality, July 28, 1891, $K$. Watanabe (Herb. Gray); prov. Shinano, Karuizawa, alt. $1000 \mathrm{~m}$. May, 1903, B. Hayata; prov. Shimotsuke, between Lake Chuzenji and Yumoto, open country, alt. 1600-1800 m., June 24, 1914, E. H. Wilson (No. 6872); same locality, September 5, 1892, C. S. Sargent; same locality, August 11, 1905, J. G. Jack; Nikko region, alt. 500-1800 m., May 22, flowers, October 19, fruit, 1914, $E$. H. Wilson (Nos. 6727, 7670); prov. Uzen, foot of Adzuma-san, grassy slopes, alt. 1000 m., October 23, 1914, E. H. Wilson (No. 7192); without locality, June 7, 1913, K. Sakurai; prov. Rikuchu, round base of Hayachine-san, June 4, 1905, U. Faurie (No. 6784). Hokkaido, prov. Oshima, Hakodate, cultivated, 1855, C. Wright (Herb. Gray).

Cultivated: Arnold Arboretum (Nos. 861-1, 861-4, 861-5, 861-6); Hort. Kew, May 18 (flowers), August 7 (leaves), 1880, G. Nicholson (No. 807, Herb. Arnold Arboretum).

This handsome species is common over a great part of Hondo, the main island of Japan. I am familiar with it from the neighborhood of Kamo, on the Kwan-8ai railroad beyond Nara, northward to the foot-hills of Hayachine-san. It is a special feature of the moorlands round the base of sacred Fuji-san and of Ontake-san, and of open grass and scrub-clad places in the Nikko region and elsewhere. Matsumura reports it from Higo province in Kyushu but I have not seen it wild anywhere in this southern island. It is cultivated in and around Hakodate in Hokkaido but I can find no record of its growing wild in that island. Wherever I have seen this Azalea wild it was scattered in open grass and scrub-clad country, never in woods or dense thickets and obviously it is sun-loving. It is a sturdy-growing plant, with fairly stout, erect shoots, as much as two metres high and a metre through; usually, however, it is less than a metre high and broad. The flowering season is from about the last week in April to the end of June, according to locality. The flowers appear before the leaves, and the corolla varies in color from orange-red to flamered or almost red; they are broad funnel-shape, from 5 to $6 \mathrm{~cm}$. flowers are produced 6 to 12 together in umbellate corymbs at the end of shoots. The calyx is small, obtusely 5-lobed with many (rarely few) straight, bristle-like gray hairs; the flower-stalk and annual shoot are also clothed with similar bristles, though occasionally these are wanting on the foot-stalks. The outside of the corolla is velutinous. The stamens, five in number and of unequal length, are shorter than the corolla, with pilose flaments and dark brown anthers. The ovary is villose, and the fruit is erect, oblong-ovoid to cylindric, from 2 to 2.5 
cm. long, grooved, shining brown, often bloomy in color, pilose and villose with scattered hairs, and is subtended by the persistent calyx. The winter-buds are ovoid, acute or subacute, gray-brown and very slightly puberulous, but the scales are margined with a row of white, nearly straight hairs. The leaves are more or less spatulate to oblanceolate, from 5 to $10 \mathrm{~cm}$. long and from 1.5 to $3 \mathrm{~cm}$. broad; when mature they are green on both surfaces, strongly veined and have scattered, appressed, bristly hairs pointing toward the apex of the leaf on the upper surface and on the under-surface of the primary and secondary veins; the margins are ciliate, the apex is tipped by a glandular mucro and the base is narrowed to the short petiole. When unfolding, both surfaces of the leaf, but more especially the lower, are often sparsely covered with a short, soft pubescence, but this is soon thrown off. In late autumn the leaves are quite glabrous except for the appressed bristles and the cilia on the margins, and change to red and red-purple. The character of the leaves is important, since it affords an easy and accurate means of distinguishing the species from its Chinese relative (R. molle G. Don).

The history of the introduction of this Japanese Azalea into western gardens is considerably involved. A Hollander, J. B. Groenewegen, in Sempervirens, XIX. 532 (1890), states that he received seeds of this plant direct from Japan in 1861, and raised many plants which he afterward sold to a Belgian friend, by whom they were distributed among Belgian nurserymen, including Louis van Houtte. Later these plants were hybridised with other cultivated species and varieties and many beautiful plants were raised. In 1863 Maximowicz introduced seeds to Petrograd, where plants were raised which flowered and were figured by Regel in the Gartenflora, XVI. 289, t. 556 (1867). In 1869 seeds were distributed from Petrograd. Hooker in figuring it in the Botanical Magazine, XCVII. t. 5905 (1871), states that the specimens were communicated by William Bull, nurseryman, Chelsea, with whom it flowered for the first time in March, 1870 . Seeds were received at the Arnold Arboretum on April 3, 1876, from the Jardin des Plantes, Paris, and plants flowered in Professor Sargent's garden in the epring of 1880. Seedlings raised from this stock flowered in the Arboretum in 1884. In 1890 Dr. W. S. Bigelow sent seeds from Japan to this Arboretum, and in 1892 Professor Sargent also sent seeds of it in quantity. Plants raised from this latter source have for many years been well established here and seeds from them have been widely distributed. In the Arnold Arboretum $R$. japonicum is perfectly hardy, grows freely and vigorously and flowers profusely every season. With its large trusses of bright to dull flamecolored flowers it is strikingly handsome and is worthy of a place in every garden. That in the past it has been neglected is undoubtedly due to its having been confused with its less hardy Chinese relative and with hybrid and seminal forms of both species. The error was started by Siebold and Zuccarini in 1846 and Miquel followed them; Gray was first to give the Japanese plant specific rank under a new name. Miquel, Regel and Maximowicz in the 60 's all recognised it as distinct from the Chinese plant and ranked it as a variety. After this for about forty years botanists merged it under the Chinese species and until Suringar in a critical, painstaking account in the Gartenflora, LVII. 516 (1908) established its right to be considered a good species. From even a cursory glance at the literature it is evident that the nurserymen of Belgium and Holland, at any rate, all along recognised the two plants as distinct.

The Japanese name for $R$. japonicum is "Renge-tsutsuji," and a form with slightly different colored flowers is "Beni-renge-tsutsuji." To the latter the name var. rosea has been given by Ito (Icon. Pl. Jap. I. No. 5, 4 [1913]). The colors indicated by the two Japanese names are merely extremes and merge inextricably into each other. Though this Azalea is now grown in some quantity in 
the nurseries round Tokyo and Osaka for export it is but little used by the Japanese in their own gardens, probably because it is not amenable to clipping.

In western gardens the first to raise and name varieties of $R$. japonicum from seed was Louis van Houtte of Ghent, Belgium, who published (in the Fl. des Serr. XIX. 177 [1873]) an article, accompanied by four plates. Enthusiastic on the future possibilities of this plant, he named and described twenty kinds. Among these are some of the best seminal kinds of this Azalea yet produced. The first of them to attain popularity was "Comte de Gomer," which is figured in the Revue Horticulture Belge, I. 97, t. (1875), by Kerchove de Denterghen under the name of Azalea mollis "Comte de Gomer." In 1879, Messers James Veitch \& Sons exhibited it before the Royal Horticultural Society under the same name and it received a First Class certificate. It is figured by Richard Dean in the Floral Magazine, XVIII. t. 367 (1879), and is still among the best kinds raised. Others of the same stock are " Alphonse Lavallée," "Baron Edmond de Rothschild," " Comte Papadopoli," "Consul Pêcher" and "Charles Kékulé." In his article Van Houtte makes no mention of using the Chinese plant but his figure 2033 suggests that plant. Hig t. 2035, depicting white flowers with yellow blotch on upper petal is presumably the variety "Chevalier A. de Réali," and suggests an albino form of the Chinese plant rather than of the Japanese species. I have seen no specimen of this, but the leaves should tell its origin. In this connection, however, it is well to remember that although only recently definitely known, the yellow-flowered form (f. aureum) of the Japanese species might have been raised from the seedlings distributed by Groenewegen or from the Petrograd stock. I saw the f. aureum in the British Consulate garden in Hakodate in 1914 and the plant might well have been growing somewhere in the town when Maximowicz was there in 1861. In reading Van Houtte's account the inference certainly is that all the forms he mentions and figures are of the Japanese plant, and Van Houtte, of course, knew the Chinese plant well. At this late date it is not possible to be sure, but I incline to the belief that the yellow-flowered form of the Japanese species appeared among the seedlings raised from Groenewegen's or Maximowicz's seeds.

\section{Rhododendron japonicum $f$. aureum Wilson, $n$. $f$.}

Rhododendron sinense Tanaka, Useful Pl. Japan, 74, No. 652, fig. (1891), not Sweet.

Rhododendron sinense var. flavescens Ito, Icon. Pl. Jap. I. No. 5, p. 4 (1913), not Sweet.

Japan: Hondo, prov. Musashi, brought from Chichibu mountains, cultivated, Botanic Gardens, Tokyo, May 11, 1917, E. H. Wilson (No. 8414, type); prov. Kawachi, between Yomomoto and Ikedo, cultivated, said to have been brought from round Tokyo, May 8 , 1918, E. H. Wilson (No. 10,351).

Except for its rich, deep yellow flowers there is nothing to distinguish this form from the typical $R$. japonicum. I was informed by Dr. Nakai that this form grows wild mixed with the type on Chichibu mountains in the northwestern part of Musashi province and that the plant my specimens are from came from there. I did not see it wild but Dr. Nakai's statement was confirmed to me by various horticulturists. I saw it in gardens in Hakodate in 1914, and in nurseries not far from Osaka in 1918. The winter-buds are pale colored and afford an easy means of distinguishing it from the type. The Japanese name for this plant is "Ki-tsutsuji" or "Ki-renge-tsutsuji" and Tanaka's figure cited above is quite good. As far as I 
can discover it was first introduced to America in the spring of 1917 among plants of the type imported from the Yokohama Nursery Company by Mr. J. S. Ames, North Easton, Mass. In 1919 I brought back plants from Japan to the Arnold Arboretum. Whether this plant has reached Europe I do not know, but there is no mention of it in Millais's recent work on Rhododendrons. In this connection it should be mentioned that Maximowicz (in Mém. Acad. Sci. St. Pétersbourg, sér. 7, XVI. No. 9, 29 (Rhod d. As. Or.) [1870]) speaks of the form with yellow flowers as rare, but it must be remembered that he confuses the Japanese and Chinese species and calls both $R$. sinense. Maximowicz identifies this plant with the "Rjuku Tsutsusi, lillifera Insulae Luconiae, flore languidé luteo, petalis, surrectis, punctis saturatioribus variegatis" and with "Rjuku Tsutsuai flore igneo, punctis petalorum croceis, apicibus rufis" (Kaempfer, Amoen. Exot. 848 [1712]). What the first named of Kaempfer's plant is I do not know, neither can I find out the "Insulae Luconiae;" the description, however, would fit our new form (aureum) or the Chinese species. The "Rjuku Tsutsusi fi. igneo" is $R$. scabrum G. Don ( $R$. sublanceolatum Miquel). Personally I doubt if Kaempfer saw or heard of $R$. japonicum or its form aureum, since they are not favorite garden plants in Japan, neither do they grow wild by the road he traversed from Nagasaki to Tokyo.

A recently raised hybrid between $R$. japonicum Suring. and $R$. canadense Zabel is: -

$\times$ Rhododendron Fraseri W. Watson in Gard. Chron. ser. 3, LXVII. $225(1920){ }^{1}$

Rhododendron luteum Sweet, Hort. Brit. ed. 2, 343 (1830), not Azalea lutea L. - Schneider, Ill. Handb. Laubholzk. II. 1046 (1912), not II. 500 (1911). - Rehder in Bailey, Stand. Cycl. Hort. V. 2942 (1916).

Azalea pontica Linnaeus, Spec. 150 (1753), not $R$. ponticum Linnaeus, Pallas, Fl. Ross. II. 51, t. 19 (1788). - Andrews, Bot. Rep. I. t. 16 (1797). Schmidt, Öster. Baumz. III. 44, t. 169 (1800). - Marschall a Bieberstein, Fl. Taur.-Caucas. I. 144 (1808); III. 136 (1819). - Hovey, Mag. Hort. IV. 276, 367 (1838). - De Candolle, Prodr. VII. pt. 2, 718 (1839).

I Azalea flava Hoffmannsegg, Verz. Pflanzenkult. 61 (1826).

Anthodendron ponticum Reichenbach in Mösseler, Handb. Geroächsk. II. aufl. 1. 309 (1827); Fl. Germ. Excur. I. 416 (1830).

Rhododendron flavum G. Don, Gen. Syst. III. 847 (1834), not Pallas. - Nyman, Consp. Fl. Europ. 491 (1878-82). - Schneider, Ill. Handb. Laubholzk. II. 499, figs. $328 \mathrm{n}-\mathrm{q}, 329 \mathrm{e}-\mathrm{h}$ (1911). - Bean, Trees and Shrubs Brit. Isl. II. 356 (1914). - Millais, Rhodod. 165 t. (1917). - Boissier, Fl. Or. III. 972 (1875). - Kuzentzof, Fl. Caucas. Crit. IV. pt. 1, 31, 488 (1901, 1906).

Rhododendron flavum var. coronarium Sweet, Brit. Flow. Gard. ser. 2, IV. t. 331 (1836).

Azalea arborea Linnaeus apud De Candolle, Prodr. VII. pt. 2, 718 (1839), as a synonym.

Rhododendron ponticum Schreber apud De Candolle, Prodr. VII. pt. 2, 718 (1839), not Linnaeus, as a synonym.

Azalea Pontica a. flava De Candolle, Prodr. VII. pt. 2, 718 (1839).

Azalea pontica var. autumnalis K. Koch in Linnaea XVII. 281 (1843).

Anthodendron flavum Reichenbach apud K. Koch, Dendr. II. pt. 2, 184 (1872), as a synonym. - Schneider, Ill. Handb. Laubholzk. II. 499 (1911).

Azalea pontica "Goldlack" Hesse in Gartenf. LII. 48 (1903).

1 See page 185. 
Caucasus, near summit of Dariel Pass, south side $2000 \mathrm{~m}$. alt., July 24, 1903, C. S. Sargent; Vladikavkaz, April 22, 1902, A. Fomine; Mt. Beschtau, June, July, R. F. Hohenacker; prov. Ossetia, Alagir, swamps, May 10, Sept. 12, 1901, R. Marcowicz. Pontus region, "Ciganadagh," July 20,1889, P. Sintenis (No. 1357); Sumila, in woods, July 31, 1889, P. Sintenis (No. 2017).

Cultivated: Arnold Arboretum (No. 3159-1) from seeds collected on the Caucasus by C. Schneider, June, August 28, 1917, A. Rehder; Hort. Holm Lea, May and September, 1880; Bot. Gard. Cambridge, Mass., May 31, 1916, A. Rehder; Hort. Kew, May 19, August 9, 1880, G. Nicholson (No. 835); Breslau, Schneitniger Park, June 13, July 23, 1902, C. Baenitz; Hort. Bot. Göttingen, May 22, 1893, A. Rehder (No. 1574).

This well-known species is geographically isolated from its relatives and has a rather remarkable distribution. It is native of the Caucasus Mountains, the Pontus region of the Black Sea, of Cilicia, and also of eastern Europe (Lithuania, southeastern Poland, Volhynia and in southwestern Russia). It is a broad, densely branched shrub from 2.5 to $4 \mathrm{~m}$. high and as much as $6 \mathrm{~m}$. in diameter. The branches are twiggy and clothed when young with glandular, villose hairs. The leaves are scattered, oblong-lanceolate often broadest above the middle, from 4 to $12 \mathrm{~cm}$. long and from 1.5 to $3.5 \mathrm{~cm}$. long, acute or obtuse, mucronate, narrowed to the base, the margin is serrulate and ciliate, and on both surfaces are scattered, appressed, short glandular bristles and short curled pale gray pubescence which later disappears. The petioles, calyx and outside of the corolla tube are glandular. The richly fragrant flowers are borne from 10 to 12 together in clusters at the end of the naked shoots. The calyx is green, deeply divided into 5 oblong or ovate, glandular-ciliate lobes from 2 to $5 \mathrm{~mm}$. long. The corolla is yellow, from $4.5 \mathrm{~cm}$. in diameter with a narrow, cylindric tube from 1.5 to $2 \mathrm{~cm}$. long. The stamens are long exserted but overtopped by the pistil which has a glandular ovary, slender style and capitate stigma. The fruit is cylindric, from 2 to $2.5 \mathrm{~cm}$. long and from 0.5 to $0.8 \mathrm{~cm}$. wide, furrowed and glabrescent.

This Azalea was discovered by Tournefort on the eastern side of the Black Sea during his voyage to the Levant $(1700-02)$ and is described in his Corollarium Institutionum rei herbariae, p. 42 (1703), as "Chamaerhododendros Pontica, maxims, Mespili folio, flore luteo"; he also figures it in Mémoires de l'Académie royale des sciences, 348 (1704). A long account of it is given in his Voyage du Levant, II. 99 (1718). Buxbaum in his Plantarum minus cognitarum centuria V. 36, fig. 69 (1740) gives a crude figure of it under Tournefort's name. It was on this description and figure that Linnaeus based his Azalea pontica. The plant was introduced into England from the Caucasus by Pallas, who sent seeds to Messers Lee \& Kennedy of Hammersmith in 1792, with whom they germinated the following year. In 1796, Mr. Anthony Hove of Warsaw found this Azalea on the north side of the Black Sea near Oczakow in marshy places, on the banks of the rivers Dnieper and Dniester, and on the Asia Minor side of the Black Sea round Trebizond. Mr. Hove sent seeds to Watson, a nurseryman of Islington, and plants flowered in a greenhouse in 1798. According to Schmidt it was found in Volhynia by Dr. Besser, and was introduced to the Botanic Garden at Vienna before 1800. I have not been able to ascertain exactly when it was introduced into this country, but according to Hovey 
it was a familiar plant in gardens round Boston, Mass., in 1838. In this Arboretum the Pontic Azalea is not properly hardy. This Azalea has been much used in hybridising and crosses between it and various American species have originated the popular "Ghent Azaleas" of gardens which should be known as $\times R$. gandaw vense Rehder. ${ }^{1}$ According to Millais (Rhodod. [1917]) A. Waterer has crossed $\boldsymbol{R}$. luteum and $R$. molle and such a hybrid is figured by Millais opposite page 198.

A variety with large flowers is:-

Rhododendron luteum var. macranthum Wilson, n. comb.

Rhododendron flavum var. macranthum Bean, Trees and.Shrubs Brit. Isl. II. 357 (1914). - Millais, Rhodod. 165 (1917).

The flowers of this variety are described as being $6.5 \mathrm{~cm}$. wide.

There is also the obscure:-

RHododendron loureiriana G. Don, Gen. Syst. III. 846 (1834). Maximowicz in Mém. Acad. Sci. St. Pétersbourg, sér. 7, XVI. No. 9, 49 (Rhodod. As. Or.) (1870). - Millais, Rhodod. 204 (1917).

Azalea punctata Loureiro Fl. Cochinch. 113 (1790).

This is said to be native of Cochinchina and was described with lanceolate, glabrous leaves scabrous at the margin and with a white corolla dotted with red, as are also the calyx, anthers and ovary. No Azalea answering this description has since been found, and very probably Loureiro made a mistake in referring his plant to that genus.

These are all the Azaleas at present known from the Old World but Dumont de Courset (Bot. Cult. ed. 2, III. 337 [1811]) mentions Azalea fimbriata, A. lugens and $A$. vittata. He gives no descriptions but says the first two are from China, the third from the Indies, and that they are growing in English gardens. Probably they are referable to $R$. Simsii or $R$. indicum but it is impossible to identify them with certainty. In Iwasaki's Japanese Herbal, Phonzo Zoufou, issued in 1828, a number of colored pictures of Azaleas are given. These figures are so crudely drawn that I find it impossible to determine, with any degree of certainty, what species and forms they represent. However, in the new edition, now being issued under the editorship of Messers Shirai \& Onuma, technical names are given, and in Volume XX (Poisonous Plants, pt. 3 ) K. Ōnuma makes three new combinations. If his determinations are correct his $R$. macranthum var. polypetalum should be referred as a synonym to $R$. indicum f. polypetalum Wils., his $R$. macranthum f. semperfiorens to $R$. indicum f. variegatum DC., and his $R$. Nakaharai var. linearifolium to $R$. linearifolium $\mathrm{S}$. \& Z.

1 See page 178. 



\section{THE AZALEAS OF NORTH AMERICA}

BY

ALFRED REHDER 



\section{THE AZALEAS OF NORTH AMERICA}

\section{INTRODUCTION}

THe Azaleas, as the term is generally understood, are the deciduous species of the genus Rhododendron, which, as far as concerns the American species, seem well separated from the evergreen Rhododendrons; this explains to some extent the tendency of many recent American botanists to consider the two groups generically distinct, but if we take into consideration the Asiatic species, the differences become less pronounced, and therefore it seems better to limit the genus as proposed by Salisbury, D. and G. Don, Maximowicz and most recent authors. In dealing with the American Azaleas we restrict the term to the species of the sections Pentanthera and Rhodora which both belong to the same subgenus and exclude Azaleastrum and Therorhodion, though they, too, have deciduous leaves, but they differ considerably in their inflorescence and are best considered distinct subgenera; they are, moreover, not Azaleas in the usual sense of the word. The subgenus Azaleastrum differs chiefly in its usually one-flowered lateral inflorescences, and Therorhodion in the flowers being borne in terminal racemes at the end of leafy shoots, while in the subgenus Anthodendron to which Pentanthera and Rhodora belong the flowers are borne in leafless umbel-like racemes, or rarely solitary, at the end of the shoots of the previous season. I prefer to use the name Anthodendron first proposed by Reichenbach as a generic name and later used by Endlicher as a subgeneric name instead of Azalea, as it is an older subgeneric name and as, moreover, Azalea of Linnaeus upon which that subgeneric name is based does not belong here but to another genus, as explained on page 116 under Anthodendron.

A short history of the genus, as far as it concerns the American species with which we are dealing, may be given here; more detailed accounts will be found under the different species. The 
first American species recorded is Rhododendron viscosum, of which we find a figure published in 1691 by Plukenet (Phytogr. I. t. 161, fig. 4) under the name Cistus virginiana flore et odore Periclymeni after a drawing made from nature by John Banister, an English missionary in Virginia who took great interest in botany and sent in 1680 a catalogue of Virginian plants to Ray. A few years later Plukenet (Mant. 49) mentioned the plant now known as $R$. nudiflorum under the name Cistus virginiana Periclymeni flore ampiiore minus odorato. Both species were introduced into England by Peter Collinson before 1730 and of $R$. nudiflorum a good colored plate was published by Trew in 1750 ( $P l$. Select. Ehret. t. 48), while the first colored plate of R. viscosum was published by Meerburgh in 1798 ( $P l$. Select. Icon. t. 9). Linnaeus when publishing his Species plantarum in $1753 \mathrm{knew}$ only these two species which he referred to the genus Azalea and named $A$. viscosa and $A$. lutea, changing the latter name to $A$. nudiflora in the second edition of his work. In the same edition, in 1762, he described Rhodora canadensis introduced some time before the year 1756 from Canada to Paris and figured first by Duhamel in 1760 (Sem. Pl. Add. 10, t. 27, fig. 2). In 1763 Adanson (Fam. $P l .164)$ proposed the name Tsutsusi based on Kaempfer's t. 846 which is R. obtusum var. Kaempferi, and cites "Azalea L." as a synonym; though not an American plant, this is mentioned here, because Small in the North American Flora considers $A$. indica $\mathrm{L}$., under which Linnaeus cites Kaempfer's tab. 846, the type of the genus Azalea. In 1766 Crantz (Inst. II. 468) proposed the new name Hochenwartia for Rhodora, because it was not the Rhodora of Pliny. Gmelin (Syst. Nat. II. pt. 1, 694) in 1791 united Rhodora with Rhododendron, and Salisbury in 1796 (Prodr. 286) first recognized the close relationship of most Azaleas to the genus Rhododendron; he referred the American Azaleas and Rhodora to the genus Rhododendron, retaining the name Azalea for $A$. procumbens, one of the two species upon which Linnaeus founded the genus. In 1803 Michaux ( $F l$. $B o r .-A m$. I. 150) described two new species, $A$. calendulacea and $A$. canescens; the former had been mentioned as long before as 1749 by Colden but without sufficient description. It was mentioned again in 1791 by W. Bartram, who discovered it in 1776 and describes its beauty in glowing terms. The second species is possibly identical with one of Aiton's varieties of $\boldsymbol{A}$. nudiflora 
and its introduction would be in that case prior to 1789. In 1811 Willdenow (Berl. Baumz. ed. 2, 49) described from cultivated plants $A$. speciosa identical with one of Aiton's varieties of A. nudiflora and the following year Loiseleur Deslongchamps (Nouv. Duhamel. V. 224) described A. rosea also from cultivated plants. Pursh in 1814 describes as a new species $A$. arborescens and raises three of Aiton's varieties of $A$. viscosa and one of $A$. nudiflora to specific rank. In $1822 \mathrm{D}$. Don (in Edinb. Philos. Jour. VI. 47) transferred, like Salisbury twentysix years before, the species of Azalea except $A$. procumbens to Rhododendron. In this he was followed by Torrey, G. Don, Endlicher, Maximowicz, Bentham \& Hooker and most recent authors, except that Maximowicz, Bentham \& Hooker and later authors took up Desvaux's name Loiseleuria for Azalea procumbens. In 1827 Reichenbach, who like the two Dons and Endlicher retained the name Azalea for A. procumbens, proposed the genus Anthodendron (in Moessler, Handb. Gewächsk. I. 244) for A. pontica, A. nudiflora and A. viscosa. G. Don (Gen. Syst. III. 84) in 1834 was the first botanist to subdivide the genus Rhododendron into sections and he proposed the sections Pentanthera and Rhodora with which we are here concerned. After 1814 no new species were added until the year 1855, when A. californica Torr. \& Gray (Rh. occidentale Gray) from California was described; it was introduced by Lobb about 1850. The very distinct $R$. Vaseyi was discovered in 1878 by George Vasey and described the following year by A. Gray; it was introduced into cultivation about the same time. In 1891 Greene (in Pittonia, II. 172) described $R$. sonomense as a new species, but this is only a form of $R$. occidentale. In 1892 Otto Kuntze, who took the year 1737 as the starting point for generic nomenclature and consequently considered Azalea the older generic name, transferred all the species of Rhododendron known to him to Azalea. In 1901 Small (in Bull. Torr. Bot. Club, XXVIII. 360 ) described as a new species $A$. candida now referred to R. canescens as a variety, and in 1903 (Fl. S. E. U.S. 883) he described $A$. oblongifolia and $A$. serrulata and separated $R$. Vaseyi as a distinct genus under the name Biltia. In 1913 ( $l$. c. ed. 2,1356 ) he adds two new species $A$. austrina and $A$. prunifolia, and in 1914 (in $N . A m$. Fl. XXIX. 42) A. prinophylla identical with $A$. rosea Loisel. (R. roseum Rehd.). In 1917 Ashe 
(in Bull. Charleston Mus. XIII. 26) published A. atlantica as a new species and three years later $A$. neglecta (in Bull. Torr. Bot. Club, XLVII. 581 [1920]) here referred to $R$. atlanticum as a form. One new species and several new varieties are described in this paper. Of these recent species $R$. austrinum was introduced into cultivation in 1914, R. oblongifolium in 1917 and $R$. serrulatum and $R$. prunifolium in 1918, all through the agency of the Arnold Arboretum. Rhododendron atlanticum has been cultivated for several years by W. W. Ashe in Washington and by Professor Coker in the Arboretum of the University of North Carolina at Chapel Hill. Rhododendron alabamense is the only species not yet in cultivation.

Soon after the introduction of the first American Azaleas to England about 1730 they become favorite garden plants and at the beginning of the last century there were already several species and many varieties in cultivation which played an important part among the so-called American plants. By hybridization between themselyes and with the Rhododendron luteum introduced at the end of the 18th century and also with evergreen Rhododendrons the garden forms began rapidly to increase in numbers and in 1836 Loddiges cultivated in his nursery near London, according to his catalogue, 107 varieties and hybrids of $R$. viscosum and 43 varieties of $R$. nudiflorum and several other species and varieties. The delicate coloring of some and the brilliancy of others, combined with a delicate fragrance in several species and the hardiness of almost all these Azaleas, made them very desirable and favorite garden plants both in England and on the Continent. Hybridization in the seventies with $R$. japonicum added a new race of hybrids which are perhaps even more showy in some respects but weaker in constitution than the older hybrids generally known as Ghent Azaleas. It is, however, doubtful if any of these hybrids surpass in the brilliancy of their flowers the true species like $R$. calendulaceum and $R$. speciosum which had almost disappeared from European gardens until recently reintroduced.

The American Azaleas are chiefly confined to the Appalachian Mountains and the adjoining regions and to the Atlantic and Gulf coast region; only one species, Rhododendron occidentale, is found in the Pacific states from southern Oregon to southern California. No Azalea occurs south of the United States bound- 
ary; the most southern species are $R$. serrulatum which reaches middle Florida and $R$. canescens which extends in Texas nearly as far south. In the North $R$. canadense is found as far north as Labrador. The western limit of the Atlantic Azaleas runs from southern Quebec to northeastern Ohio, then through southeastern Indiana, extreme southeastern Missouri, central Arkansas and extreme eastern Oklahoma to the coast of eastern Texas. The greatest development of the group is on the Appalachian Mountains and as the centre of segregation we must consider Georgia, where eight species, half of all American species, occur.

The Azaleas are shrubs from one half to two metres or rarely to 7 metres in height and are essentially inhabitants of the temperate deciduous forest; they are mostly moisture and shade loving shrubs and most species are found on the wooded slopes of hills and mountains growing in scattered individuals intermingled with other shrubs and trees. Like most Ericaceae they are calciphobous and therefore are absent from limestone regions, although $R$. roseum is found in western New York and $R$. oblongifolium in Oklahoma on limestone soil. In spring when in bloom they form a most conspicuous feature of the woods, particularly species like $R$. calendulaceum on the mountains from Pennsylvania to Georgia with its brilliant orange or scarlet flowers and $R$. speciosum in Georgia with bright red or scarlet flowers; also $R$. nudiflorum, $R$. roseum and $R$. canescens with white to pink flowers are conspicuous, the latter being widely distributed in the woods of the southern coastal plain. The late flowering species, as $R$. viscosum and R. serrulatum, are less showy but deliciously fragrant and inhabit chiefly swamps and moist woods of the coastal plains from New England to Louisiana, though the northern species $R$. viscosum also grows on the mountains. The related $R$. arborescens with white and fragrant flowers is likewise a mountain plant. Only $R$. atlanticum is a predominant feature over large areas as it grows in open pine woods of the coastal plain chiefly in North and South Carolina. Most species have a wide distribution, particularly $R$. nudiflorum, $R$. canescens, $R$. viscosum and $R$. serrulatum; others, like $R$. speciosum, $R$. oblongifolium and $R$. atlanticum, occupy an area not more than about two to three hundred miles in length and $R$. Vaseyi, $R$. alabamense and $R$. prunifolium are more limited in distribution. 
The present study of American Azaleas is based chiefly on the collections of the Arnold Arboretum. For many years Professor Sargent has taken special interest in Azaleas and has succeeded in assembling a large amount of material, particularly from the southern states usually poorly represented in most herbaria. Besides having this material at my disposal, I have consulted the collections of the Gray Herbarium at Cambridge and of the National Herbarium at Washington and the herbaria of the New York Botanic Garden, the Academy of Natural Sciences of Philadelphia, and of the New England Botanical Club; specimens for further study were kindly loaned to me from most of these institutions and from the herbaria of the State University of Ohio, of the Missouri Botanical Garden and of the Academy of Sciences at Rochester. I also am under obligation for specimens to Professor W. C. Coker of the University of North Carolina, to Dr. K. M. Wiegand of Cornell, Mr. W. W. Ashe of Washington and Mr. John Dunbar of Rochester. I have further had the opportunity to see most of the species in their native habitats during various journeys, and the living collections of Azaleas of this Arboretum supplied me with material to study many of the species and a large number of garden forms and hybrids in the living state. The great variability of most species together with the absence of strong morphological characters within this group makes it difficult to assemble the numerous forms into well defined species and varieties. The difficulty is considerably increased if one tries to elucidate the innumerable garden forms and hybrids, as few of these forms are adequately described or figured and herbarium or living material of only a small percentage of them is available.

The Azaleas form a distinct subgenus of the Rhododendron for which we propose to use Endlicher's subgeneric name Anthodendron, as we do not believe that the name Azalea used for it by most authors can be correctly applied to this subgenus, as will be seen from the following enumeration of synonyms and the appended remarks. 


\section{THE SUBGENUS ANTHODENDRON ENDL.}

\section{Rhododendron subgen. Anthodendron Endlicher, Gen. 759 (1839),}

emended.

Azalea Linnaeus, Spec. 150 (1753), as to species 1-4. - Desvaux in Jour. Bot. Appl. I. 35 (1813). - Roemer \& Schultes, Syst. IV. 374 (1819), excluding species 12 and 13. - Gray, Man. 268 (1848). - K. Koch, Dendr. II. 1, 171 (1872). - Rehder in Bailey, Cycl. Am. Hort. I. 119 (1900), excluding A. albifiora, semibarbata, kamschatica. - Britton \& Brown, Ill. Fl. II. 558 (1897). - Britton, Man. 698 (1901). - Small in N. Am. Fl. XXIX. 41 (1914).

Anthodendron Reichenbach in Moessler, Handb. Gewächsk. I. 244, 308 (1827); Fl. Germ. Exc. 416 (1831).

Rhododendron sect. Pentanthera G. Don, Gen. Syst. III. 846 (1834). - See also page 124.

Rhododendron a. Anthodendron, Endlicher, Gen. 759 (1839).

Rhododendron subgen. Azalea Planchon in Rev. Hort. 1854, 43; with Tsusia as distinct subgenus. - Maximowicz in Bull. Acad. Sci. St. Pétersbourg, XV. 229 (1870); in Mém. Acad. Sci. St. Pétersbourg, sér. 7, XVI. 9, 24 (1870), as section, with Tsusia as distinct section. - Bentham \& Hooker, Gen. II. 601 (1876), as series, with Tsusia as distinct group. - Gray, Syn. Fl. N. Am. II. 1, 40 (1878). - Dippel, Handb. Laubholak. I. 410 (1889), with Tsusia as distinct subgenus. - Drude in Engler \& Prantl, Nat. Pflanzenfam. IV. 1, 37 (1889). - Koehne, Deutsch. Dendr. 454 (1893), excluding Azaleastrum and Therorhodion, - Rehder \& Wilson in Sargent, $P l$. Wilson. I. 516 (1913), excluding Chionastrum and Azaleastrum. - Rehder in Bailey, Stand. Cycl. Hort. V. 2937 (1916), excluding Azaleastrum.

Shrubs or occasionally small trees with deciduous or half evergreen rarely evergreen leaves, usually more or less strigose- or villose-pubescent, sometimes glabrous, never lepidote-glandular. Flowers from a terminal bud, one or several to many in umbel-like racemes. Corolla funnel-form to rotate, rarely campanulate, usually with a distinct often long and slender tube, rarely two-lipped and divided partly almost to the base. Stamens 5 to 10 , of unequal length. Ovary 5-celled, usually strigose and pubescent, rarely glabrous, never lepidote.

The type section of the subgenus is Pentanthera and the type species Rhododendron luteum Sweet (Azalea pontica Linnaeus). In North America this subgenus is represented by sixteen species.

Our conception of the subgenus coincides exactly with that of Drude (l. c.), while all other authors draw its limits narrower or wider, as shown in the synonomy given above. In former publications I had included Azaleastrum and Therorhodion in this subgenus, but as the inflorescens of these two groups is entirely different from that of the type of this subgenus, I prefer to consider these two groups as coördinate subgenera and restrict the sections belonging to Anthodendron to Tsutsutai G. Don, Sciadorhodion Rehd. \& Wils., Rhodora G. Don and Pentanthera G. Don, of which the first two are exclusively Asiatic, while the last two contain American and Asiatic species. It does not seem advisable to 
maintain Tsutsutsi as a distinct subgenus, since it is closely connected with Rhodora by the new section Sciadorhodion.

As the name Azalea used first by Planchon as a subgeneric name is not the oldest subgeneric name for the group, and as, moreover, the generic name Arales upon which the name of the subgenus is based properly belongs as a synonym to Loiseleuria, ${ }^{1}$ either Don's Penthanthera or Endlicher's Anthodendron must take its place. As Pentanthera has been proposed originally as a sectional name and used as such by later authors it may be retained as the name for the section to which it should apparently be restricted by the meaning of its name, and Anthodendron first published in 1827 as a genus may be adopted in an enlarged sense as the proper name for the subgenus.

1 See Jour. Arnold Arboretum, II. 156 (1921). 


\section{KEY TO THE AMERICAN SPECIES OF THE SUBGENUS ANTHODENDRON}

Corolla rotate or rotate-campanulate, more or less two-lipped; stamens 7 to 10 , rarely 5 or 6. (Sect. Rhodora).

Stamens 10; corolla two-lipped with the two lower lobes divided to the base, rose-purple; leaves tomentulose beneath, glaucous.

R. canadense, p. 120.

Stamens 5 to 7 ; corolla with short tube, slightly two-lipped, pink or whitish, spotted; leaves glabrous and green beneath . . . . . R. Vaseyi, p. 122.

Corolla funnel-form, subregular, the tube longer or little shorter than the lobes; stamens 5. (Sect. Pentanthera).

Color of corolla yellow or orange to scarlet and red, rarely white or pinkish with a large yellow blotch.

Corolla white or pinkish with large yellow blotch, the tube gradually dilated above the middle; flowers with or after the leaves.

Corolla orange or yellow to scarlet or red.

R. occidentale, p. 125.

Flowers with or shortly after the leaves; winter-buds glabrous.

Corolla-tube more or less glandular outside, about as long or shorter than the lobes, yellow to scarlet . . . . R. calendulaceum, p. 127.

Corolla-tube finely pubescent and glandless outside, longer than the lobes, red to scarlet . . . . . . . . R. speciosum, p. 131.

Flowers before the leaves; winter-buds pubescent; corolla yellow, the tube often reddish . . . . . . . . . R. austrinum, p. 146.

Color of corolla white to deep pink or carmine, crimson in $R$. prunifolium, without a conspicuous yellow blotch.

Flowers before or with the leaves.

Flower-buds without prominent rows of stipitate glands at apex; much branched shrubs usually more than $0.5 \mathrm{~m}$. tall, rarely low.

Corolla-tube more or less pilose, glandular or eglandular, gradually dilated near the apex.

Corolla-tube about as long as the lobes, dilated above the middle; stamens declinate; corolla usually pink.

Leaves glabrous beneath except the strigose midrib, bright green; corolla hirsute and glandless or glandular-pilose outside; winterbuds glabrous rarely thinly pubescent . . R. nudiflorum, p. 134.

Leaves pubescent beneath, sometimes nearly glabrous except along the midrib beneath, often bluish green; corolla glandular outside; winter-buds pubescent . . . . R. roseum, p. 138.

Corolla-tube distinctly longer than the lobe, glandular or eglandular; corolla white; winter-buds glabrous; leaves pubescent and glaucescent beneath . . . . . . . R. alabamense, p. 141.

Corolla-tube densely and finely villose and sparingly stipitate-glandular or eglandular, slender and abruptly expanded at apex; winterbuds pubescent; leaves usually pubescent beneath.

R. canescens, p. 143 . 
Flower-buds with prominent rows of conspicuous long-stipitate glands at apex; corolla glandular-pilose, not or slightly villose outside, the tube abruptly expanded at apex; low stoloniferous shrub with simple or little branched stems . . . . $R$. atlanticum, p. 147.

Flowers expanding after the leaves are fully developed; the flower-buds with prominent rows of stipitate glands at apex, rarely quite glabrous.

Branchlets and leaves more or less strigose or pubescent; style usually pubescent.

Calyx-lobes oblong to oblong-lanceolate, rarely short; corolla finely villose; leaves usually large, 4 to $10 \mathrm{~cm}$. long; winter-buds pubescent; flowers appearing before the terminal buds are formed.

R. oblongifolium, p. 150.

Calyx-lobes short, semi-orbicular to ovate; corolla villose and glandularpilose; leaves usually 2 to $6 \mathrm{~cm}$. long; winter-buds glabrous or pubescent; flowers appearing usually when the terminal buds are forming.

Winter-buds with many (usually more than 15) aristate-mucronate scales, usually pale with conspicuous dark margin; branchlets bright red-brown, usually densely strigose, specially toward the apex; leaves often pubescent beneath, particularly at the end of shoots, serrulate-ciliate . . . . . . R. serrulatum, p. 153 ,

Winter-buds with fewer (usually less than 15) obtusish or acutish, usually pale brown scales; branchlets usually pale, strigillose, hispid or glabrescent; leaves glabrous, strigose on midrib beneath, pubescent only in one rare variety . R. viscosum, p. 157.

Branchlets and leaves glabrous or the leaves sometimes strigillose on midrib beneath; style usually glabrous; winter-buds glabrous.

Corolla white or pinkish, tube glandular-pilose outside; leaves glaucous beneath, generally obovate, acute or obtusish.

R. arborescens, p. 166.

Corolls crimson, tube glabrous or nearly glabrous outside; leaves light green beneath, elliptic to oblong-lanceolate, acuminate.

R. prunifolium, p. 169. 


\section{ENUMERATION OF THE SPECIES}

\section{SECT. I. RHODORA G. DoN ${ }^{1}$}

Rhododendron sect. Rhodora G. Don, Gen. Syst. III. 848 (1834). Endlicher, Gen. 759 (1839). - Dippel, Handb. Laubholzk. I. 417 (1889), as section of subgenus Azalea, excluding his Nos. 29 and 31. Koehne, Deutsch. Dendr. 455 (1893), as section of subgenus Azalea, excluding his No. 36. - Zabel in Mitt. Deutsch. Dendr. Ges. XI. 26 (1902), in part.

Rhodora Linnaeus, Spec. ed. 2, 561 (1762); Gen. ed. 6, 218 (1764).-Willdenow, Spec. I. pt. 2, 866 (1798). - De Candolle, Prodr. VII. 719 (1839). Gray, Man. 267 (1848); ed. 5, 309 (1867). - Britton \& Brown, Ill. Fl. II. 560 (1897). - Britton, Man. 699 (1901). - Small in N. Am. Fl. XXIX. 44 (1914).

Hochenwartia Crantz, Inst. II. 468 (1766).

Rhododendron sect. Azalea, ser. 2, [subser.] b, Maximowicz in Mém. Acad. Sci. St. Pétersb., sér. 7, XVI. No. IX. 28 (1870). - Bentham \& Hooker, Gen. Pl. II. 601 (1876), as subser. 2, in part. - Drude in Engler \& Prantl, Nat. Pflanzenfam. IV. 1, 37 (1889), as subgenus Azalea, § 4.

Biltia Small, Fl. S. E. U. S. 884 (1903); in N. Am. Fl. XXIX. 48 (1914).

Deciduous upright shrubs without strigose pubescence, densely or loosely branched, sometimes irregularly dichotomous, but not whorled; branchlets glabrous or pilose to hirsute, winter-buds of many imbricate scales, glabrous or puberulous. Leaves scattered or crowded at the end of the branchlets. Flowers from a terminal bud, the leafy shoots from separate lateral buds; corolla twolipped, or rotate-campanulate, rarely campanulate; stamens 10 , or in one species 7 or occasionally 5 or 6 , not or only little longer than the corolla, usually declinate; ovary pubescent or glabrous and stipitate-glandular. Capsule usually with rather thin valves.

The type species of this section is $R$. canadense Torr. The section contains five species, of which two are native of eastern North America and three are Japanese. All these species are very distinct from each other and may be divided into three groups. The first group, containing only $R$. canadense, is characterized by the deeply two-lipped corolla, the lower lip divided nearly to the base, the glandularpubescent and sparingly setose ovary, the puberulous branchlets and the tomentulose under side of the usually oblong leaves and the glandular-puberulous narrowly oblong capsule. The second group with three species, of which $R$. Vaseyi is one, has a rotate-campanulate slightly two-lipped corolla, a stipitate-glandular but otherwise glabrous or sometimes quite glabrous ovary, an ovoid to oblong glandular-hirsute or stipitate-glandular or glabrous capsule, and glabrous or pilose leaves and branchlets. The third group, consisting only of $\boldsymbol{R}$. nipponicum, has a campanulate nearly regular corolla, with the lobes shorter than the tube, a glandu-

1 See page 91 for the Old World species of this section. 
lar-pilose but otherwise glabrous ovary, hirsute branchlets and hirsute large obovate leaves, a very thin-valved oblong-ovoid capsule almost destitute of glands at maturity; its flowers appear after the full development of the leaves, while in all the other species of this group they open before the leaves unfold. The petiole of the shoot-leaves in $R$. Vaseyi, $R$. nipponicum and $R$. Albrechtii is somewhat docurrent on the stem, leaving an elongated scar distinctly longer than broad.

In the section Rhodora I have included $R$. Vaseyi as suggested by Gray and as done by Dippel and by Koehne; by Small this has been made the type of a new genus Biltia, chiefly distinguished by the exterior aestivation of the middle lobe of the upper lip of the corolla. This position of the posterior lobe is without doubt unusual in the genus, but can be observed at least occasionally in species related to $R$. Vaseyi. Among flowers of $R$. canadense $I$ have found a small percentage with the middle lobe of the upper lip exterior and in $R$. Schlippenbachii, which belongs to the section nearest to Rhodora and is very similar in its flowers to $\boldsymbol{R}$. Albrechtii and $R$.quinquefolium, both closely related to $R$. Vaseyi, I have found after examining numerous fresh flowers just before opening that about 15 per cent of the flowers had the middle lobe of the upper lip completely exterior and 25 to 30 per cent had one side exterior and the other side covered. This shows that the position of the upper lobe cannot be used as a reliable character to separate Biltia generically. As there is no other character to separate $R$. Vaseyi from the other species of the section Rhodora except the number of stamens, which also cannot be considered a reliable character in the genus Rhododendron, it seems best to retain it in this section.

Rhododendron canadense Torrey, Cat. Pl. 151 (in Geol. Surv. New York Assembly, No. 50) (1839). - Oakes, Cat. Vermont Pl. 190 (in Thompson, Hist. Vermont) (1842).-Wood, Classb. Bot. 235 (1845).Zabel, Syst. Verz. Muenden, 26 (1878). - Britton, Sterns, Poggenburg, Prelim. Cat. New York, 33 (1888). - Britton, Cat. Pl. N. Jersey, 162 (1889). - Dippel, Handb. Laubholzk. I. 418 (1889). - Robinson \& Fernald, Gray's New Man. ed. 7, 631 (1908). - Schneider, Ill. Handb. Laubholzk. I. 494, fig. 327 i-k, 328 f (1909). - Jackson, Cat. Fl. Worcester Co., Mass. 76 (1909). - Graves \& others, Cat. Flow. Pl. Conn. 308 (1910). - Twining, Fl. N. E. Pennsylv. 56 (1917).

Rhodora canadensis Linnaeus, Spec. ed. 2, 561 (1762). - Willdenow, Spec. I. pt. 2, 866 (1798). - Michaux, Fl. Bor.-Am. I. 259 (1803). - Pursh, Fl. Am. Sept. I. 298 (1814). - Bigelow, Fl. Boston, 104 (1814). - De Candolle, Prodr. VII. 719 (1839). - Gray, Man. 267 (1848); ed. 5, 309 (1867). Tracy, Stud. Essex Fl. 49 (1858). - Britton \& Brown, Ill. Fl. 560, fig. 2748 (1897). - Clute, Fl. Upp. Susquehanna, 70 (1898). - Britton, Man. 699 (1901). - Small, Fl. Pennsylv. 238 (1903); in N. Am. Fl. XXIX. 44 (1914).

Hochenwartia canadensis Crantz, Inst. II. 469 (1766).

Rhododendron Rhodora G. F. Gmelin, Syst. Nat. II. pt. 1, 694 (1791).Sweet, Hort. Brit. ed. 2, 343 (1830). - G. Don, Gen. Syst. III. 848 (1834).Gray, Syn. Fl. II. 1, 41 (1878). - J. Robinson, Fl. Essex Co., Mass. 73 (1880). - Macoun, Cat. Canad. Pl. II. 302 (1884). - Dame \& Colline, Fl. Middlesex Co., Mass. 63 (1888). - Perkins, Cat. Fl. Vermont, 33 (1888).Bennett, Pl. Rhode Isl. 26 (1888). - Coulter \& Watson, Gray's Man. ed. 6, 321 (1890). - Rand \& Redfield, Fl. Mt. Desert Isl. 127 (1894). - 
Deane, Fl. Metrop. Park, Mass. 53 (1896); in Rhodora, I. 94 (1899).Millais, Rhodod. 235, pl. (1917).

Azalea canadensis O. Kuntze, Rev. Gen. II. 386 (1891). - Rehder in Bailey, Cycl. Am. Hort. I. 122 (1900). ${ }^{1}$

A much-branched shrub $1 \mathrm{~m}$. tall or lese, with slender upright or ascending branches; young branchlets puberulous when young, bright yellowish red or pinkish and often slightly bloomy at the end of the first season, becoming light yellowish gray or gray the second year, later grayish brown; floral winter-buds with about 10 ovate, acuminate to acute pinkish, finely pubescent and ciliolate scales. Leaves elliptic to oblong, obtuse or acutish, cuneate at base, 2 to 4.5 rarely to $6 \mathrm{~cm}$. long and 0.8 to $1.8 \mathrm{~cm}$. broad, ciliate and revolute at the margin, dull bluish green above, usually somewhat strigillose and finely villose on the midrib, thinly grayish tomentulose beneath and usually with scattered fulvous hairs and scattered glands, and sparingly strigose on the midrib, the secondary veins diverging at nearly right angles; petioles slender, 2 to $5 \mathrm{~mm}$. long, puberulous and sparingly strigose. Flowers appearing before the leaves, in April or May or in the North in June, in 3- to 7-flowered umbel-like racemes; pedicels 3 to $7 \mathrm{~mm}$. long, puberulous, glaucous and usually sparingly glandular-pilose; calyx-lobes very short, unequal, puberulous and setosely ciliate; corolla rose-purple, two-lipped, 1.5 to $2 \mathrm{~cm}$. long, glabrous, the lower lip divided nearly or quite to the base into two nearly distinct narrow-oblong lobes, the upper lip with three short ovate lobes at apex; stamens 10, about as long as the corolla, unequal; anthers broadly ellipsoidal, $0.15 \mathrm{~mm}$. long, purple; the filaments pubescent at the lower third; style slightly longer than the stamens, 1.5 to $1.8 \mathrm{~mm}$. long, glabrous or minutely pilose near the base; ovary pubescent and slightly glandular, sparingly setose. Capsule ovoid-oblong, curved near the base, 1 to $1.5 \mathrm{~cm}$. long, slightly grooved, setose and finely puberulous, light red-brown with a pinkish bloom.

This is the most northern species of the group in North America and its range extends from Labrador and Newfoundland to southwestern Quebec and south through New England and central New York to northeastern Pennsylvania and northern New Jersey. It grows along river banks, in moist woods and in swamps. In spring it is a beautiful feature of the northern woods and swamps and its charm has inspired Emerson to a well known poem in which he calls Rhodora a rival of the Rose.

Rhododendron canadense differs from all other species of the genus by the deeply divided corolla, but in all other characters it is so closely related to the species here associated with it, that its generic separation would appear artificial, and its close

1 Prelinn. Srnon.: Chamaerhododendros Duhamel, Semis Plant. Arb. Add. 10, tab., fig. 2 (1760); Abh. Bäume Staud. Sträuch, ed. Oelhafen, I. 119, t. (1762).

Addimional Illugtrations. Coloned Plates: Meerburgh, Pl. Select. Icon. t. 23 (1798). - Bot. Mag. XIV. t. 474 (1800). - Nouv. Duhamel III. t. 53 (1806).Guimpel, Otto \& Hayne, Abb. Fremd. Holzgew. t. 14 (1825). - Emerson, Trees \& Shrubs Mass. ed. 2, II. t. opp. p. 441 (1875). - Black Figures: L'Héritier, Stirp. Nov. t. 68 (1796).--Lamarck, Encycl. Méth. Rec. Pl. II. t. 364 (1823). - Newhall, Shrubs N.E. Am. fig. 85 (1893). - Möller's Deutsch. Görtn.-Zeit. XVII. 286, fig. (1902). - Keeler, Our North. Shrubs, 359 (1903). - Garden Mag. V. 221 (1907). Country Life Am. XI. 496 (1907). - Millais, Rhodod. pl. opp. 234 (1917). - HABiT FrguRes: Möller's Deutsch. Gärtn.-Zeit. XVII. 287, fig. (1902); XXI. 73, fig. (1906). - Silva-Tarouca, Uns. Freil.-Laubgeh. fig. 65 (p. 81) (1913). - Gartenwelt, IX. 474 (1905); XIV. 85 (1910); XX. 378 (1916). 一 Gartenschönheit, I. 33 (1920). The figures 31, 32 in Jardin, XX. 57 (1905) named Rhodora canadensis represent Rhododendron dahuricum $\mathrm{L}$. 
relation to Rhododendron was perceived as early as 1791 by Gmelin who referred it to that genus. The species was first described and figured by Duhamel from a cultivated plant which flowered the first time in March, 1756, in the Botanic Garden at Paris, where it had been brought from Canada a few years earlier. Into England it was introduced by Joseph Banks in 1767.

Observations on the pollination of this species have been made by F. Hildebrand (Flora, LXIV. 501, t. 10, fig. 6, 7 (1881)), who describes the peculiar arrangement to avoid self-fertilization. When the flower opens, the apex of the style with the stigma remains enclosed in a little hood formed by the lobes of the upper lip, while visiting insects carry away pollen from the anthers; further elongation of the style forces it out of the hood and the bent style stretches itself, extending the stigma beyond the stamens, and is then in a position to be fertilized by insects carrying pollen from other flowers.

Rhododendron canadense f. albiflorum Rehder, comb. nov.

Rhododendron Rhodora f. albiflora Rand \& Redfield, Fl. Mt. Desert Isl. 127 (August, 1894).

Rhododendron canadense f. album Voss, Vilmorin's Blumengärt. I. 587 (Sept. or Oct., 1894). - Zabel in Mitt. Deutsch. Dendr. Ges. XI. 31 (1902).

A form with white flowers, occasionally found wild under the typical form, e.g. Maine, Mt. Desert, Southwest Harbor.

Rhododendron canadense f. viridifolium Fernald, n. forma.

Ramulis glabriusculis; foliis subtus sparse pilosis supra atroviridibus lucidis nec glaucis.

Nova Scotia: boggy thickets bordering Trefry's Lake, Arcadia, July 29, 1920, Fernald \& Long, No. 22,150 (TYPE in Gray Herb.).

This shrub occurs in scattered clumps on the shore of Trefry's Lake, the only place we met it, the ordinary form of the species with glaucous foliage being generally common in the province. - M. L. FERnatd.

Rhododendron Vaseyi A. Gray in Proc. Am. Acad. XV. 48 (1879); in Bot. Gaz. VIII. 282 (1883); Syn. Fl. ed. 2, II, 1, 398 (1886).Donnell Smith in Bull. Torr. Bot. Club, XV. 164 (1888). - Sargent in Gard. \& For. I. 376, fig. 60 (1888). - Dippel, Handb. Laubholzk. I. 419 (1889). - Skan in Bot. Mag. CXXXII. t. 8081 (1906). Schneider, Ill. Handb. Laubholzk. II, 495, fig. 325 o, 327 c - d (1909).Millais, Rhodod. 257, t. opp. p. 10 and 20 (1917).

Azalea Vaseyi Rehder in Möller's Deutsch. Gärtn.-Zeit. XIV. 332, fig. (1899); in Bailey, Cycl. Am. Hort. I. 122 (1900).

Biltia Vaseyi Small, Fl. S. E. U. S. 884 (1903); in N.Am. Fl. XXIX. 49 (1914). ${ }^{1}$

1 Additronal Illustrations. Colored Plates: Meehan's Monthl. VII. 121, t. 7 (1897). - Garden, LIV. t. 1191, opp. p. 282 (1898). - Black Figures: Gard. Chron. sér. 3, XX. 71 (1896); LI. 313 (1912)._Möller's Deutsch.Gärtn.-Zeit. XIV. 332 (1899). - Gard. LVI. 122 (1899); LXXVI. 332 (1912); LXXXIV. 239 (1920). Gard. Mag. V. 219 (1907). - Country Life Am. XI. 499 (1907). - Bean, Trees \& Shrubs Gt. Brit. II. 384 (1914). - Bailey, Stand. Cycl. Hort. V. fig. 3391 (1916), after Gard. \& For. - H 
An upright, rather irregularly branched shrub with spreading branches, occasionally $5 \mathrm{~m}$. tall; young branchlets puberulous and sparingly pilose at first, soon glabrous, light red-brown at the end of the season, becoming brown or grayish brown the second year; older branches grayish brown with flaky or shredding bark; floral winter-buds large, broadly ovoid, obtuse, with 7 to 10 orbicular-ovate scales, rounded or the upper ones truncate or slightly emarginate at apex, mucronulate, the basal ones acuminate, glabrous or the upper and inner ones minutely puberulous, white-ciliate and sometimes glandular on the margin. Leaves elliptic or elliptic-oblong, acuminate, cuneate at base, 5 to $12 \mathrm{~cm}$. long and 2 to $5 \mathrm{~cm}$. broad, usually slightly undulate on the margin, ciliate, dark green and glabrous above except the sparingly and finely villose midrib, rarely sparingly strigillose, light green beneath and glabrous or sparingly pilose on the midrib; petioles slender, 3 to $7 \mathrm{~mm}$. long, glabrous or sparingly pilose. Flowers appearing in May before the leaves, in 5- to 8-flowered umbel-like racemes; pedicels 0.5 to $1.5 \mathrm{~cm}$. long, with short-stipitate glands, sometimes sparingly so; calyx oblique, with shallow rounded lobes, erose-glandular on the margin; corolla rotate-campanulate 2.5 to $3 \mathrm{~cm}$. long, two-lipped, light rose-colored with orange or red-orange dots at the base of the upper lobes, glabrous, tube very short, about $5 \mathrm{~mm}$. long, the lobes oblong, rounded at apex, the upper lip less deeply divided, with the middle lobe exterior in bud; stamens usually 7 , sometimes 5 or 6 , unequal, the longer ones exceeding the corolla; filaments glabrous; anthers ellipsoid, 1 to $2 \mathrm{~mm}$. long, pinkish; style 2.5 to $3 \mathrm{~cm}$. long, longer than stamens, glabrous or with few stipitate glands near the base. Capsule narrow-oblong, 1.2 to $1.5 \mathrm{~cm}$. long, with a thin narrow keel on back of the rather thin valves.

This species is very distinct from all other American Azaleas and seems most nearly related to the Japanese $R$. Albrechtii Maxim. which, however, differs considerably in its 10 stamens, the more pubescent obovate leaves and the shorter and thicker more woody, hispid capsule. It is restricted to the higher mountains of western North Carolina, where it grows at an altitude of from 3000 to 5500 feet on mountain slopes, in ravines and sometimes in swamps. It was first discovered in 1878 on Balsam Mountain near Webster, Jackson County, by George Vasey and soon afterward introduced into cultivation, for in 1880 the Arnold Arboretum received a living plant from G. C. Woolson \& Co. of Passaic, New Jersey. It has proved perfectly hardy near Boston and is now well known in gardens in this country as well as in Europe and valued for its handsome pale pink flowers appearing in great profusion in spring before the leaves unfold. It has been found escaped from cultivation near Halifax, Mass., as shown by the following specimens in the herbarium of the New England Botanical Club: swamp near an abandoned nursery, May 30, 1907, A. S. Pease (No. 9998); sandy soil, probably part of old nursery, May $30,1907, J . A$. Cushman (No. 653).

Rhododendron Vaseyi f. album Nicholson in Kew Hand-list Arb. II. 57 (1896), as var., name only. - Bean, Trees \& Shrubs Gt. Brit. II. 384 (1914), as var. - Rehder in Mitt. Deutsch. Dendr. Ges. XXIV. (1915), 225 (1916).

This form with white flowers was found at the Arnold Arboretum and also in Kew Gardens among seedlings of the typical form; all transitions from pure pink to white can be found among seedlings of this species.

Gard. LVI. 119 (1899). - Gartenwelt, XVI. 231 (1912); XXII. 363 (1918). - SilvaTarouca, Uns. Freil.-Laubgeh. fig. 64 (1913). - Gard. LXXIX. 302 (1915). - Gard. Mag. XXX. 259 (1920), - Gartenschörheit, I. 33 (1920). 


\section{Sect. II. Pentanthera G. Don}

Rhododendron sect. Pentanthera G. Don, Gen. Syst. III. 846 (1834). - Rehder \& Wilson in Sargent, Pl. Wilson. I. 549 (1913).

Azalea Linnaeus, Spec. 150 (1753), as to species 2 to 4. - De Candolle, Prodr. VII. 715 (1838), excluding species 13, 14, 16. - Britton \& Brown, Ill. Fl. II. 558 (1897).

Rhododendron a. Anthodendron Endlicher, Gen. 759 (1839). - Zabel in Mitt. Deutsch. Dendr. Ges. XI. 28 (1902), as section.

Theis "Salisb. in coll. 1817" ex De Candolle, Prodr. VII. 715 (1839), synonym. Rhododendron sect. Azalea Regel in Act. Hort. Petrop. I. 162 (1871), excluding species 5 and 8.

Azalea subgen. Pentanthera K. Koch, Dendr. II. 1, 186 (1872).

Azalea subgen. Emazalea K. Koch, Dendr. II. 1, 179 (1872), as to species 11, 12. Rhododendron sect. Euazalea Dippel, Handb. Laubholzk. I. 411 (1889).Koehne, Deutsch. Dendr. 458 (1893).

Deciduous upright shrubs, rarely almost tree-like, sometimes stoloniferous, with usually irregularly whorled branches; branchlets usually more or less strigose or hirsute, sometimes glabrous. Winter-buds with many imbricate scales. Leaves scattered. Flowers several to many from a terminal bud, the leafy shoots from separate lateral buds; corolla funnel-form, subregular, the tube about as long or longer than the limb; stamens 5, usually much exserted; ovary more or less strigose or setose. Capsule with woody valves.

The type species of this section is Rhododendron luteum Sweet. The section contains besides the sixteen American species enumerated below, two species from eastern Asia, $R$. molle Miq. and $R$. japonicum Suring., and one from southeastern Europe and western Asia, $R$. luteum Sweet. In America it occupies two distinct geographical areas: one on the Atlantic coast, extending from southern Quebec to central Florida and west to Vermont, eastern Ohio, southeastern Missouri, central Alabama, extreme eastern Oklahoma and eastern Texas; and one on the Pacific coast from southern Oregon to southern California.

From the section $R$ hodora this section is easily distinguished by the funnel-form subregular corolla with a distinct cylindric tube longer or little shorter than the lobes and by the 5 stamens; the ovary is always densely villose and strigillose, with or without glands. Most species show a wide range of variation particularly in the pubescence of the leaves and in the color of the flowers. The leaves vary from nearly glabrous to pubescent in $R$. oblongifolium, $R$. serrulatum, $R$. canescens, $R$. roseum, $R$. occidentale and $R$. atianticum; they are always glabrous except the midrib in $R$. nudiflorum, $R$. arborescens and $R$. prunifolium and usually so in $R$. viscosum; they are always pubescent in $R$. alabamense and, though usually only slightly so, in $R$. calendulacerum and $R$. speciosum. The pubescence of the winterbuds which affords a character hitherto neglected, shows less variation; they vary from glabrous to finely pubescent in $R$. nudiflorum, $R$. iviscosum, $R$. serrulatum, $R$. atlanticum and $R$. occidentale; they are always glabrous in $R$. calendulaceum, $\boldsymbol{R}$. 'speciosum, $R$. arborescens, $R$. alabamense and $R$. prunifolium and always pubescent in $R$. canescens, $R$. roseum and $R$. oblongifolium. The branchlets are in most species more or less pubescent, usually villose and strigillose, but are alrays 
glabrous in $R$. arborescens and $R$. prunifolium and sometimes nearly glabrous in R. nudiflorum, $R$. atlanticum, $R$. viscosum and $R$. occidentale. The sepals vary in most species from semi-orbicular or nearly obsolete to oval or oblong, but usually are rather small; in $R$. oblongifolium they are mostly oblong and usually well developed in $R$. arborescens and $R$. occidentale. The corolla is usually glandularpubescent outside, glabrous or nearly glabrous in $R$. prunifolium, finely villose and nearly destitute of glands in $R$. oblongifolium and $R$. canescens, pilose and eglandular in typical $R$. nudiflorum and in $R$. speciosum. The tube is in most species pubescent inside, glabrous or nearly so in $R$. atlanticum, $R$. viscosum, $R$. serrulatum, and usually in $R$. oblongifolium. The color of the corolla is in most species white to pinkish or pink, pale yellow in $R$. austrinum, bright yellow to scarlet or bright red in $R$. calenduilaceum, bright red in $R$. speciosum and crimson in $R$. prusnifolium. The stamens are always pubescent, usually for two-thirds of their length. The style is pubescent at the base in most species and only occasionally glabrous or nearly glabrous, but always glabrous in $R$. prunifolium and usually so in $R$. arborescens. The pubescence of the ovary is mostly villose, more or less overlaid by strigose or setose hairs which are at least partly gland-tipped in $\boldsymbol{R}$. calendulaceum, occasionally glandless in $R$. austrinum, $R$. oblongifolium, $R$. serrulatum, $R$. viscosum, $R$. arborescens, but glandless or nearly so in $R$. speciosum, typical $R$. nudiflorum, $R$. canescens, occasionally glandular in $R$. atlanticum and $R$. prunifolium. In $R$. canescens there are often only a few strigose hairs at the base and the whole ovary appears clothed with silky white hairs. The pubescence of the capsule is similar to that of the ovary; the shape varies much in the same species and is generally ovoid-oblong; the most distinct capsule is that of $R$. canescens, which is slender and nearly cylindric, almost destitute of bristles, but covered with a fine grayish pubescence.

The species of this section may be divided into four fairly distinct groups. The first group contains $R$. occidentale, $R$. calendulaceum and $R$. speciosum. The corolla is rather large with a tube dilated gradually above the middle, spreading into a wide limb with broad, ovate lobes; the color is bright yellow to scarlet or white to pink and the upper lobe is marked by a large orange blotch. The flowers appear with or in $R$. occidentale of ten after the leaves. The second group contains $R$. roseum, $R$. austrinum, $R$. nudiflorum, $R$. alabamense and $R$. canescens. The corolla is generally smaller with a narrow cylindric tube rather abruptly dilated at the apex into a distinctly oblique limb with comparatively narrower lobes; the color is white to pink or pale yellow in one species, without a conspicuous yellow blotch; the stamens are distinctly declinate. The flowers appear shortly before the leaves expand or with the leaves. The third group contains $R$. atlanticum, $\boldsymbol{R}$. oblongifolium, $\boldsymbol{R}$. serrulatum, $\boldsymbol{R}$. viscosum and $\boldsymbol{R}$. arborescens. The corolla is similar in shape to that of the preceding group but often larger and its color is white to pink without a yellow blotch and the tube is often glabrous inside. The flower-buds are marked by conspicuous rows of long-stipitate glands on the back of the corolla-lobes. The flowers are very fragrant and appear after the leaves are fully grown or with the leaves in $R$. atlanticum, which thus forms a connecting link with the preceding group. The fourth group contains only $R$. prunifolium. The flowers are comparatively large and shaped like that of the preceding group, but of crimson color, and appear after the leaves are fully formed. The whole plant including the corolla tube is glabrous except the pedicels and a few hairs on the midrib and veins of the under side of the leaves which are distinctly acuminate, while they are acute to obtusish in all other species of this group.

Rhododendron occidentale A. Gray, Bot. Calif. I. 458 (1876); Syn. Fl. II. 140 (1878).-Behr, Fl. Vicin. San Francisco, 173 (1888).-Dippel, 
Handb. Laubholzk. I. 415, fig. 268 (1889). - Jepson, Fl. W. Middle Cal. 369 (1901); ed. 2, 311 (1911). - Schneider, Ill. Handb. Laubholzk. II. 501, fig. 328 l-m, 329 i-k (1911). - Millais, Rhodod. 220 (1917).

Azalea calendulacea Hooker \& Arnott, Bot. Capt. Beechey Voy. 362 (1841), not Michaux. - Bentham, Pl. Hartweg. 321 (1849).

Azalea nudiflora var. ciliata Kellogg in Proc. Calif. Acad. Sci. I. 60 (1855).

Azalea californica Torrey \& Gray apud Durand in Jour. Acad. Philadelphia, ser. 2, III. 94 (1855). - Small in N. Am. Fl. XXIX. 44 (1914).

Azalea occidentalis Torrey \& Gray in Rep. Explor. Surv. Miss. Pacif. Ocean, IV. 116 (1856). - Hooker in Bot. Mag. LXXXIII. t. 5005 (1857). Howell, Fl. N.W. Coast, I. 422 (1901). ${ }^{3}$

A shrub to $3 \mathrm{~m}$.; young branchlets soft-pubescent or glabrous, brown at the end of the first season; floral winter-buds finely pubescent or sometimes nearly glabrous with numerous ovate to ovate-lanceolate, acuminate and aristate-mucronate or mucronulate scales. Leaves elliptic to oblong-lanceolate, acute or obtusish, gland-tipped, cuneate or attenuate at base, 3 to $9 \mathrm{~cm}$. long, ciliate, thinly pubescent on both surfaces, rarely nearly glabrous, at maturity chartaceous, glabrous or nearly glabrous except pubescent on the midrib above and sparingly strigose on the midrib and sometimes on the veins beneath; petioles rather stout, 1 to $5 \mathrm{~mm}$. long. Flowers appearing with or after the leaves or rarely before the leaves, 6 to 12 in umbel-like racemes; pedicels 0.5 to $1.5 \mathrm{~cm}$. long, pubescent and more or less glandular, sometimes pilose and glandless, rarely nearly glabrous; sepals broadly ovate to oblong-ovate, obtuse, 1.5 to 4 or sometimes $5 \mathrm{~mm}$. long, densely ciliate with usually setose, gland-tipped or glandless hairs; corolla white or sometimes pink with a yellow blotch on the upper lobe or on the three upper lobes, the tube about $2 \mathrm{~cm}$. long, or sometimes shorter, gradually dilated upwards, villose and glandular-pilose outside, the lobes about as long as the tube, broadovate, acute or acutish; stamens exserted, more than twice as long as the tube; filaments pilose below the middle; anthers 2.5 to $3 \mathrm{~mm}$. long, whitish; style about as long or longer than stamens, finely pubescent or sometimes villose above the base, rarely nearly glabrous; ovary pilose and glandular. Capsule ovate-oblong, 1 to $2 \mathrm{~cm}$. Iong, setosely pilose or sometimes furnished with short gland-tipped hairs.

This species is distributed from southern Oregon to southern California, growing by brooks among the mountains up to 5000 or sometimes 5800 feet altitude. It is the only Azalea west of the Rocky Mountains and was first discovered during the Expedition of Captain Beechey in 1827 and was also collected later by Douglas, Hartweg and Burke. Hooker as well as Bentham referred it to $A$. calendulacea, and it was not recognized as a distinct species until named in 1855 by Torrey \& Gray $A$. californica and a year later by them $A$. occidentale.

Rhododendron occidentale seems most closely related to $R$. calendulaceum, from which it is easily and chiefly distinguished by the color of its flowers, which otherwise in size and shape resemble those of that species more than those of other American species. It is very variable in the shape and size of its leaves, in the pubescence of all its parts and also to some extent in the size of the flowers; the sepals are apparently always well developed, never nearly obsolete, as is of ten the case in the Eastern

1 Additional Illugtrations. Colored Plates: Fl. des Serres, XIV. t. 1432 (1861). - Gard.XXXIV. 416, t. 673 (1888).-Black FIgURe: Gard.Chron. ser. 2, XXVI. 105, fig. 21 (1886). ${ }^{2}-$ HaBIT FigdRes: Gartenwelt, XI. 8 (1906); XV. 650 (1911).

"The legend under the wood-cut reads "flowers orange and crimson, fragrant" which is hardly correct; in the text the flowers are described as deep rosy-red. 
species. It exhibits a remarkable latitude in the time of blooming; I have before me a specimen collected by Orcutt in San Diego County in April without any leaf buds developed and in northern California I collected it myself in full bloom as late as August 25 with the winter-buds of the new growth fully developed; generally it flowers between the middle of June and the middle of July, just when the young leaves are fully grown. The autumnal tints of this species are very brilliant. In Garden and Forest (III. 626 [1890] ), E. W. Hammond says "in the fall of the year its leaves glow with such a profusion of scarlet and crimson mingled with the gold and green, that it produces the most delightful effects."

Behr (Fl. Vicin. San Francisco, 173) states that the root contains a powerful narcotic, and according to Jepson ( $F l$. W. Middle Calif. ed. 2, 311) the plant is feared by sheepmen as poisonous.

Rhododendron occidentale was introduced into cultivation by William Lobb, who sent seeds from California about 1850 to the Veitchian Nurseries, where it flowered in 1857. It is tenderer than many other American Azaleas and has not proved hardy at the Arnold Arboretum.

Rhododendron occidentale var. sonomense Rehder, var. nov.

Rhododendron sonomense Greene in Pittonia, II. 172 (1891). - Zabel in Mitt. Deutsch. Dendr. Ges. XI. 29 (1902). — Millais, Rhodod. 245 (1917).

This variety differs from the type according to Greene chiefly in its smaller narrower leaves, smaller rose-colored and very fragrant flowers; the odor of typical $R$. occidentale is mephitic according to Greene. It occurs on dry slopes in the mountains of Sonoma County. It does not seem to be in cultivation outside of California.

Rhododendron calendulaceum Torrey, Fl. U. S. 425 (1824). G. Don, Gen. Syst. III. 847 (1834). - Bigelow \& Hor, Fl. Lancast. 56 (in Trans. Med. Convent. Ohio) (1841); Reprint, p. 10 (1841). - Gray, Syn. Fl. N. Am. II. 1, 41 (1878). - Dippel, Handb. Laubholzk. I. 413, fig. 266 (1889). - Millspaugh, Prelim. Cat. Fl. W. Va. 402 (1892). Blake in Rhodora, XX, 53 (1918).

Azalea lutea Linnaeus, Spec. 150 (1753), only as to Colden's synonym. Weston, Bot. Univ. I. 16 (1770). - Michaux, Jour. ed. C. S. Sargent, 111, 116 (in Proc. Am. Philos. Soc. XXVI.) (1889). - Britton \& Brown, Ill. Fl. II. 559, fig. 2745 (1897). - Gattinger, Fl. Tenn. 131 (1901). Britton, Man. 698 (1901). - Porter, Fl. Pennsylv. 238 (1903).- Millspaugh, Liv. Fl. W. Va. 323 (W. Va. Geol. Surv.) (1913). - Small, Fl. S. E. U. S. 883 (1903); in N. Am. Fl. XXIX. 41 (1914). - Shreve \& others, Pl. Life Maryland, 466 (1910). - Schaffner, Cat. Ohio Vasc. Pl. 204 (in Ohio Biol. Surv. I.) (1914). - Griggs, Bot. Surv. Sugar Grov. Reg. 328 (Ohio Biol. Surv. I.) (1914). - Taylor, Fl. Vicin. N. Y. 489 (in Mem. N. Y. Bot. Gard. V.) (1915).

Azalea nudiflora Linnaeus, Spec. ed. 2, 214 (1762), as to Colden's synonym only. Azalea flammea Bartram, Travels, I. 327 (1791), name only.

Azalea calendulacea Michaux, Fl. Bor.-Am. I. 151 (1803), excluding var. a. Pursh, Fl. Am. Sept. 151 (1814). - Elliott, Sketch Bot. I. 238 (1821), excluding var. a. and c. - De Candolle, Prodr. VII. 717 (1839). - Gray, Man. 268 (1848); ed. 5, 299 (1872). - M. A. Curtis, Descript. Trees \& Shrubs, 98 (in Geol. Nat. Hist. Surv. N. Car. III. Bot.) (1860). 
Azalea aurantiaca Dietrich, Darst. Vorz. Zierpfl. 4, t. 1 (1803).1

Azalea pontica $\beta$. A. calendulacea Persoon, Syn. I. 212 (1805).

? Azalea nudiflora var. h. lutea Elliott, Sketch Bot. I. 241 (1821).

? Azalea flava Michaux, Jour. ed. C. S. Sargent, 111 (in Proc. Am. Philos. Soc. XXVI.) (1889), name only.

Rhododendron luteum Schneider, Ill. Handb. Laubholzk. II. 500, fg. 329 q-r, 320 a (1911), not Sweet.2

A shrub with erect and spreading branches, usually 1.5 to 3 , rarely to $5 \mathrm{~m}$. tall; young branchlets pubescent and strigillose; floral winter-buds with broadly ovate scales, rounded or even emarginate at the apiculate apex, brown, glabrous except the densely white-ciliolate margin. Leaves broadly elliptic to ellipticoblong or obovate-oblong, rarely obovate, 4 to $8 \mathrm{~cm}$. long, and 1.5 to $3.5 \mathrm{~cm}$. broad, acute and gland-tipped, broadly cuneate at base, finely pubescent above and more densely so beneath when young, particularly on and along the midrib; petioles 2 to $5 \mathrm{~mm}$. long, pubescent. Flowers in May and June, in usually 5- to 7-flowered umbels, expanding with or shortly after the leaves; pedicels setulose and usually glandular; calyx-lobes usually oblong and 3 to $4 \mathrm{~mm}$. long or ovate and 1 to $2 \mathrm{~mm}$. long, obtuse, setulose outside, ciliate with long gland-tipped hairs; corolla funnelform, yellow or orange to scarlet, with orange blotch on the upper lip, the cylindric tube gradually dilated above the middle, 1.5 to $2 \mathrm{~cm}$. long, glandular-pilose, and pubescent outside, the lobes ovate, about $2 \mathrm{~cm}$. long and $1.5 \mathrm{~cm}$. broad, usually wavy at the margin, abruptly contracted into a short point, slightly pubescent outside; stamens nearly three times as long as corolla-tube; the filaments pubescent below the middle or on the lower third, the anthers about $3 \mathrm{~mm}$. long; style pilose toward the base, sometimes glabrous, 6 to $7 \mathrm{~cm}$. long, about as long or longer then stamens; ovary covered with long setose, partly gland-tipped hairs. Capsule ovoid-oblong, 1.5 to $2 \mathrm{~cm}$. long, setose and pubescent.

This species is confined to the Appalachian Mountain region from Pennsylvania to northern Georgia; according to the herbarium material seen, its western limit runs from western Pennsylvania (Venango County) through southeastern Ohio (Fairfield County), ${ }^{3}$ eastern Kentucky (Rockcastle County), eastern Tennessee (Knox County) to northern Georgia (Gwinnett County); its eastern limit

${ }^{3}$ DAppel and Schneider cite 1801 as date of publication, which would give Dietrich's name priority over $A$. calendulacea, but the part which contains $A$. aurantiaca is dated 1803 as well on the title-page as on the cover. The cover bears the title "Modeblumen für Botaniker . . . Sechstes Heft." The first part of the latter publication is the one which is dated 1801. There is no technical description given, and this together with the fact that the part was published during the second half of the year, as it contains a letter dated July 1, 1803, makes it advisable to give Michaux's name the preference.

- Prelinnean Name: Azalea erecta foliis ovatis integris alternis flore luteo piloso praecoci Colden in Act. Soc. Sci. Upsala, IV. 93 (1749).

Adpitional Illustrations. Black Figures: Loudon, Arb. Brit. II. 1142, fig. 946 (1838); reproduced in Gard. XXIX. 550 (1886). - Britton \& Brown, Ill. Fl. II. fig. 2745 (1897); ed. 2, II. fig. 3217 (1913). - Keeler, Our North. Shrubs, 351 (1903).-Gard. Mag. V. 218 (1907).-Country Life Am. XI. 496 (1907).Stevens, Ill. Guide Flow. Pl. t. 114, fig. 3 (1910). - Schneider, Ill. Handb. Laubholak. I. fig. 329 q-r, 330 a (1911).

3 This station, interesting on account of its isolation, was first discovered in 1841 according to Bigelow \& Hor, Fl. Lancast. 56 (1841): "For the discovery of this splendid plant. . . we are indebted to the hospitality of Mr. Jacob Greene, who had found it a few days previously at the mouth of Clear Creek." 
extends from southern Pennsylvania (Somerset County), through West Virginia (Pocahontas County), western North Carolina (Ashe, Mitchell and Buncombe Counties), northwestern South Carolina (Spartanburg County) to northeastern Georgia (Rabun County). The type locality is the Blue Ridge Mountains in North Carolina. In most Floras the range of the species is given as extending to southern New York but I have not seen a single specimen in support of this statement which is apparently based on "Azalea erecta foliis ovatis integris alternis flore luteo piloso praecoci" enumerated by Cadwallader Colden in his Plantae Coldenghamiae (in Act. Soc. Sci. Upsala, IV. 93 [1749]). This plant has not been found again by any botanist in the state of New York; the report by Dr. Barnhart in 1895 (in Bull. Torr. Bot. Club, XXII. 282) that he discovered it in an apparently native state near Tarrytown was based on a single shrub which belonged to a plantation in a private estate, a fact Dr. Barnhart found out on the occasion of a later visit to the locality, as he himself has told me. Rhododendron calendulaceum is usually found growing scattered in open woods on mountain sides as undergrowth and along the banks of watercourses in the mountains. With its brilliant flowers ranging from yellow to scarlet it enlivens the mountain woods in early summer, and as well in its natural habitat as in the garden it must be considered one of the most gorgeous of American shrubs.

Rhododendron calendulaceum was first mentioned by Cadwallader Colden in 1749 from southern New York, as already stated, and his account was referred by Linnaeus to his Azalea lutea, which was chiefly based on material belonging to the species we now call Rhododendron nudiflorum. It was also discovered in northern Georgia at the confluence of the Savannah and Broad River, the most southern point of the range of the species, in $\mathbf{1 7 7 4}$ by William Bartram, who describes its beauty in glowing terms (Travels, I. 322 [1790]); he called it "Flame Azalea" and named it incidentally Azalea flammea in his book, but without giving a technical description. The elder Michaux collected it on the Blue Ridge Mountain in North Carolina on May 11, 1795, and called it Azalea lutea in his Journal.

When $R$. calendulaceum was first introduced into cultivation cannot be stated with certainty. If the plant figured as Azalea aurantiaca by Dietrich in 1803 and said to have been procured from England belongs to our species, it must have been sent to England before 1800. It is certain, however, that the yellow form was growing in the nurseries of J. Fraser and of Loddiges and Sons in 1812, as stated by Sims in Botanical Magazine under tab. 1721. Their plants were received from John Lyon, who brought over a large shipment of American plants in 1806.

The nomenclature of the species is somewhat involved and the name Azalea lutea which Linnaeus gave in 1753 to an American species incompletely known to him and based on citations belonging to three different species, namely $R$. nudiflorum, $R$. canescens and $R$. calendulaceum, has been recently taken up by several American botanists for our species. In the second edition of his Species plantarum, however, he changed the name to $A$. nudiflora, but retained the descriptions and the citations unchanged, augmented only by references to Kalm and Duhamel; he had then in his possession specimens collected by Kalm and representing $R$. nudiflorum which apparently induced him to change the name, noticing that the color of the flowers was not yellow. As both names Azalea lutea and A. nudiflora are based on the same citations and on the same description, they cannot be used for different plants, as has been done by Britton and by Small, and as they are chiefly based on $R$. nudiflorum and $R$. canescens, $A$. lutea cannot be taken up for our species, as Blake has shown in Rhodora. The next oldest name $A$. flammea Bartram being a nomen nudum, A. calendulacea becomes the correct name for the species, after excluding $A$. aurantiaca Dietr. for the reasons given in the footnote on page 128 . 
Small in North American Flora gives "Savannah River" as the type locality for his $A$. lutea, but if $A$. lutea of Linnaeus is taken up as the name for $R$. calendulaceum it could be based only on Cadwallader Colden's enumeration of the plant from southern New York and not on the locality given by Michaux for var. a. of his A. calendulacea. Unfortunately Michaux's specimen collected on the Savannah River near Two-Sisters Ferry and eited by him under a. flammea does not belong to $A$. calendulacea as described by him, but to $R$. speciosum, and therefore the specimen labeled in his herbarium $\beta$. crocea must be considered the type specimen and the high mountains of Carolina or more particularly the Blue Ridge Mountains of North Carolina, the type locality. Though it is against general usage to take var. $\beta$. as the type of a species which is divided into varieties, the specific description in this case appears to be chiefly based on the specimen designated var. $\beta$., particularly the character "corolla tubo hirsuto, laciniis breviore" must have been taken from var. $\beta$., for in var. a. ( $R$. speciosum Sweet) the tube is distinctly longer than the lobes and less conspicuously hirsute, also the color "floribus . . . calendulaceis" referring to Calendula which has yellow to orange flowers, indicates the mountain form, var. $\beta$., rather than var. a., which has bright red to scarlet flowers.

Rhododendron calendulaceum does not show much variation except in the color of the flowers and in the length of the sepals, which are usually oblong, but sometimes rather small; the style is normally pilose near the base, but sometimes glabrous, as in Harbison's No. 171 from Macon County, North Carolina, in Small's specimen from White Rock Mountains, Smyth County, Va., and in Britton's \& A. M. Vail's specimen from the same locality. There are also forms with partly salmoncolored flowers of which I collected a specimen myself on Roan Mountain of North Carolina, and I have before me a specimen from North Carolina stated to have pink flowers. The two following forms have been described, of which the first represents the typical form, though probably more color forms could be distinguished but this cannot be done satisfactorily without copious living material of undoubtedly spontaneous origin.

Rhododendron calendulaceum f. croceum Sweet, Hort. Brit. ed. 2, 343 (1830), as var. a. - Rehder in Mitt. Deutsch. Dendr. Ges. XXIV. (1915), 225 (1916), as forma; in Bailey, Stand. Cycl. Hort. V. 2942 (1916), as var.

Azalea calendulacea $\beta$. crocea Michaux, Fl. Bor.-Am. I."151 (1803). - Sims in Bot. Mag. XII. t. 1721 (1815). - Rehder in Bailey, Cycl. Am. Hort. I. $121,(1900) .{ }^{1}$

Flowers yellow to orange-yellow with a darker blotch, sometimes partly salmon-colored. As stated before there are all kinds of intermediate shades between the plants with scarlet flowers and those with yellow flowers.

Rhododendron calendulaceum f. aurantium Rehder, comb. nov.

Azalea calendulacea a. Ker in Bot. Reg. II. t. 145 (1816), not var. a. flammea Michaux.

Azalea aurantiaca Dietrich, Darst. Vorz. Zierpf. 4, t. 1 (1803). - Hort. apud Dumont de Courset, Bot. Cult. ed 2, III. 333 (1811), as var. of A. nudiflora.

? Azalea coccinea major Dumont de Courset, l.c. (1811), as var. of A. nudiflora.

1 Additional Reference to Colored Plate: Mag. Bot. \& Gard. II. 119, t. 36, fig. 7 (1834). 
Azalea speciosa f. aurantia Sweet, Hort. Brit. 265 (1826), name only.

Azalea coccinea aurantia Loddiges, Bot. Cab. XIII. t. 1255 (1827).

Rhododendron calendulaceum var. a. flammeum Sweet, Hort. Brit. ed. 2, 343 (1830). - Zabel in Beissner, Schelle \& Zabel, Handb. Laubholz.-Ben. 380 (1903).

Rhododendron speciosum f. aurantium Sweet, Hort. Brit. ed. 2, 343 (1830).

Azalea speciosa $\beta$. aurantia De Candolle, Prodr. VII. 117 (1838).

Azalea speciosa a. aurantiaca Kirchner in Petzold \& Kirchner, Arb. Musc. 479 (1864).

Azalea calendulacea var. fammea Rehder in Bailey, Cycl. Am. Hort. I. 121 (1900), in part.

Rhododendron calendulaceum aurantiacum Zabel in Beissner, Schelle \& Zabel, Handb. Laubholz-Ben. 380 (1903).

Rhododendron luteum var. flammeum Schneider, Ill. Handb. Laubholzk. II. 500 (1911), in part.

Flowers deep orange-red to scarlet, with large orange blotch.

Rhododendron speciosum Sweet, Hort. Brit. ed. 2, 343 (1830), not Salisbury. ${ }^{1}$ - G. Don, Gen. Syst. III. 847 (1834).

Azalea nudiflora a. coccinea Aiton, Hort. Kew. I. 202 (1789). - Sims in Bot. Mag. V. t. 180 (1792).

Azalea coccinea Sims in Bot. Mag. text to t. 180 (1792), as synonym.-Michaux, Jour. ed. C. S. Sargent, 9 (in Proc. Am. Philos. Soc. XXVI.) (1889).

Azalea fulva Michaux in Jour. Hist. Nat. I. 410 (1792), name only.2

Azalea calendulacea a. flammea Michaux, Fl. Bor.-Am. I. 151 (1803).Pursh, Fl. Am. Sept. 152 (1814).

Azalea speciosa Willdenow, Berl. Baumz. ed. 2, 49 (1811); Enum. Hort. Berol. Suppl. 10 (1813). - Guimpel, Otto \& Hayne, Abb. Fremd. Holzart. I. 37, t. 31 (1825). - Watson, Dendr. Brit. II. t. 116 (1825).

Azalea periclymenoides var. coccinea Pursh, Fl. Am. Sept. I. 152 (1814).

Azalea nudiflora Loiseleur-Deslongchamps, Herb. Amat. IV. 213, t. (1820), not Linnaeus.

Azalea calendulacea var. a. Elliott, Sketch Bot. I. 239 (1821).

Azalea coccinea major Loddiges, Bot. Cab. VII. t. 624 (1822).

Azalea speciosa a. major Sweet, Hort. Brit. 265 (1826).

1 Rhododendron speciosum Salisbury, Prodr. 287 (1796) cannot invalidate Sweet's combination, as it is a straight synonym, being only a new name for $R$. ponticum $\mathbf{L}$.

2 This is apparently the Azalea which he calls Azalea coccinea in his Journal (ed. C. S. Sargent, p. 9) and describes under the entry of the following day (p. 10) as "l'Azalea couleur de feu. La couleur de cet Azal. qui est dans toutes les parties de la fl. aussi foncée, Corolla, Etam. et Pistille, est celle de Hemerocallis fulva mais dans les lieux plus découverts et moins ombragés cet couleur est encore plus forte." This Azalea Michaux collected on April 26 and 27, 1787, after having crossed the Savannah River at Two-Sisters Ferry; in his Flora it is referred to under A. calendulacea a. flammea. In comparing the color of this plant with that of Hemerocallis fulva Michaux must have had in mind the color form figured by Redouté in his Liliaceae, tab. 16, which has red-purple flowers and was probably at that time well known in France. The color of this form agrees very well with that of $R$. speciosum, while the plant now generally cultivated as Hemerocallis fulva has orange flowers. 
? Azalea nudiflora var. thyrsiflora Gowen apud Lindley in Bot. Reg. XVI. t. 1367 (1830).

Rhododendron speciosum a. major Sweet, Hort. Brit. ed. 2, 343 (1830).

Rhododendron nudiflorum $\zeta$. coccineum Sweet, Hort. Brit. ed. 2, 343 (1830). G. Don, Gen. Syst. III. 847 (1834).

A zalea speciosa a. coccinea De Candolle, Prodr. ViI. 717 (1839).

Azalea calendulacea Darby, Bot. S. States, 422 (1855), in part.

Rhododendron calendulaceum Chapman, Fl. S. U. S. 265 (1860), in part.

Rhododendron calendulaceum f. speciosum Voss, Vilmorin's Blumengärt. I. 588 (1894). - Zabel in Beissner, Schelle \& Zabel, Handb. Laubholz-Ben. 380 (1903).

Rhododendron flammeum Sargent in Rhodod. Soc. Notes, I. 120 (1918), name only, not Azalea flammea Bartr.'

A shrub 0.3 to $2 \mathrm{~m}$. tall with slender, irregularly whorled branches; the young branchlets finely pubescent and rather densely strigillose, becoming grayish brown the second year; floral winter-buds glabrous, with generally ovate, ciliolate scales, usually rounded and mucronate at apex. Leaves obovate or elliptic to oblong, acute or obtusish, mucronulate, broad-cuneate at base, 3 to $6 \mathrm{~cm}$. long and 1.2 to 2 or sometimes to $3 \mathrm{~cm}$. broad, strigillose above, finely pubescent beneath, more densely on the leaves of the shoots and particularly on the veins, often strigose on the midrib, sometimes nearly glabrous except on the midrib beneath, setosely ciliate, subchartaceous at maturity, with prominent lateral veins; petioles 3 to $5 \mathrm{~mm}$. long, pubescent and strigillose. Flowers appearing with the leaves end of April and beginning of May in 6- to 15-flowered umbel-like racemes, scarlet or bright red, with a large orange blotch on the upper lobe; pedicels strigillose, not glandular; sepals roundish ovate to oblong, 0.5 to $3 \mathrm{~mm}$. long, long-ciliate, pubescent or nearly glabrous outside; corolla funnel-form, tube cylindric, rather slender, 2 to $2.5 \mathrm{~cm}$. long, longer than the limb, rather abruptly dilated at the apex, covered outside with fine villose pubescence interspersed with long pilose not gland-tipped hairs, pubescent inside, lobes ovate, abruptly acuminate, 1.5 to $2 \mathrm{~cm}$. long; stamens much exserted, more than twice as long as tube and slightly shorter than the style, the filaments pubescent below the middle; style 5 to $6 \mathrm{~cm}$. long, finely pubescent at the lower third, usually purplish above; ovary covered with long setose hairs, not glandular. Fruit ovoid to narrow-oblong narrowed toward the apex, 2 to $3 \mathrm{~cm}$. long, strigose.

This species is distributed through central Georgia from the Savannah River to the Chattahoochee River, its range extending north to Gwinnett County and to Oconee County of South Carolina, south to Screven County in the east and to Muscogee County in the west. ${ }^{2}$ It is usually a low shrub and grows in open dry woods and on sand hills, often covering large stretches and is very conspicuous when in bloom on account of the brilliant color of its flowers.

1 Additional Illostrations. Colored Plates: Drapiez, Herb. Amat. I. t. 51 (1828), as A. nudiflora. - ? Audubon, Birds Am. II. t. 198 (1831); Quarto ed. II. 86 \& 104 (1841), poorly colored. - Black Figures: Dippel, Handb. Laubholzk. I. fig. 266 (1889), after Watson, Dendr. Brit., as $R$. calendulaceum. - Voss, Vilmorin's Blumengärt. I. 588 (1894), same as preceding.

${ }^{2}$ Mohr mentions under A. nudiflora ( $P$. Life Ala. 653 [1901]) a form with flame or deep orange-colored flowers from Springhill, Mobile County, which he refers to A. nudiflora var. rutilans Pursh; this may be either an undescribed color form of $\boldsymbol{R}$. canescens or it may be $R$. speciosum and in this case the range of $R$. speciosum would extend to southwestern Alabama. I have not seen any specimen of this form. 
South Carolina. Oconee County : Newry, April 26, 1906, H.D. House (No. 1934, 1935, 1936; in Nat. Herb.).

Georgia. Gwinnett County: Thompson's Mills, May 2, 1909, H. A. Allard (No. 181, in Nat. Herb.). Dekalb County: on and about Stone Mountain, May 1-18, 1895, J. K. Small; base of Stone Mountain, May 3, 1899, C. S. Sargent and Wm. M. Canby; without precise locality, May 23, 1897, H. Eggert (in N. Y. Bot. Gard. Herb.). Fulton County: Atlanta, May, 1869, Wm. M. Canby (in Nat. Herb.). Baldwin County: Milledgeville, Samuel Boykin (in Herb. Philadelphia Acad. Nat. Sci.); south of Milledgeville, May 6, 1914, T. G. Harbison (Nos. 1561-1570). Muskogee County: Columbia, above the falls, 1912, T.G. Harbison. Richmond County: sand hills at Belair, A. Cuthbert, April 26, 1903; near Bath, April 29, 1914, C. S. Sargent; near Augusta, April 29 and October 7, 1914, C. S. Sargent; near Hephzibah, May 9, 1920, A. Rehder (No. 930). Screven County: Ogeechee River, 1847, H. C. Pater (in Gray Herb.). - Middle Georgia, Dr. Leavenworth; Ocmulgee River, April, 1847, T. C. Porter (both in Herb. Philadelphia Acad. Nat. Sci.).

Though this species was introduced into cultivation more than a century ago and described and figured by early European botanists it has never been recognized by an American botanist. The exact date of its first discovery and of its introduction into cultivation is not known with certainty. It was first mentioned without adequate description by Aiton in 1789 as Azalea nudiflora var. coccinea and figured three years later by Sims in the Botanical Magazine under the same name; Sims says "whether it was originally introduced to the country by Mrs. Norman of Bromley or by Mr. Bewick of Clapham in Surrey we cannot with certainty assert; true it is that Azalea coccinea was little known here till the sale of Mr. Bewick's plants in 17 "; and he adds that the plants were sold at high prices, one of them producing 20 guineas. Possibly plants were sent before 1789 by William Bartram, who must have known this plant, as it grows in a region traversed by him in search of plants. Later, in 1811, the plant was described by Willdenow as Azalea speciosa from cultivated plants growing in the Berlin Botanic Garden, the origin of which is not stated and it was figured by Guimpel in 1825 . By Michaux it was collected near Two-Sisters Ferry on the Savannah River, about twenty-five miles above Savannah, and his are the first wild specimens we know. In Michaux's Flora they were confused with Azalea calendulacea and enumerated under his var. flammea. Pursh also in 1814 confused the two, though he was the first to refer Aiton's $A$. nudiflora var. coccinea to Michaux's var. flammea and thus identified the plant growing near Savannah with Aiton's plant. I have no doubt that Aiton's, Willdenow's and Michaux's plants are identical. Of Azalea nudiflora var. coccinea there is a specimen in the British Museum which probably served for Sims's figure in the Botanical Magazine. Mr. W. J. Bean kindly compared flowers of Rhododendron speciosum from the specimens collected by me near Augusta, Georgia, with that specimen and states that they agree with it and that $A$. nudiflora var. coccinea certainly is not $R$. calendulaceum with which it had been confused. Of $A$. speciosa there is a specimen in the Berlin Botanical Museum, of which Professor L. Diels obligingly sent me a flower, which also agrees with the Georgia plant and not with $R$. calendulaceum. 
Of Michaux's specimens of var. a. flammeum collected according to his Journal near Two-Sisters Ferry, Georgia, on April 27, 1787, and of his specimens of var. $\beta$. croceum I have photographs before me which show that the latter variety is $R$. calendulaceum, while a. flammeum differs chiefly in its slenderer corolla-tube distinctly longer than the limb and not conspicuously glandular-hairy and in the smaller corolla-lobes and thus agrees with the plant here called $R$. speciosum.

$R$ hododendron speciosum has been usually confused with $R$. calendulaceum, and particularly with the scarlet-flowered form of it, from which it may be chiefly distinguished by the slenderer corolla-tube more abruptly enlarged at the apex into the limb and longer than the limb, by the absence of glandular hairs on the corolla-tube which is covered with a short villous pubescence interspersed with pilose hairs and by the generally smaller and comparatively broader leaves. The color of the flowers is always scarlet or bright red and never varies to yellow, as it does in $\boldsymbol{R}$. calendulaceum and the flowers are more numerous in each inflorescence. It shows little variation except in shape and size of sepals, which may be oblong and up to $3 \mathrm{~mm}$. long or nearly obsolete, and in the shape and size of the capsules. Geographically the two species are well separated; $R$. calendulaceum is essentially an Alleghanian plant, while $R$. speciosum belongs to the Piedmont region of Georgia, but in northern Georgia the ranges of the two species touch and at Thompson's Mill, Gwinnett County, both species have been collected by H. A. Allard.

Though the species was well known in cultivation at the beginning of the last century, it later almost disappeared from the gardens until it was reintroduced in 1916 through the Arnold Arboretum, though in 1881 it was still cultivated at Kew as Azalea coccinea major according to a specimen before me. There is also in the herbarium of the Arnold Arboretum a specimen collected by $\mathbf{H}$. Zabel in the Botanic Garden at Muenden, Hanover, from a plant received as Azalea coccinea from Booth's nursery at Flottbeck near Hamburg in 1872. It is certainly as handsome as $R$. calendulaceum, but probably more tender and not suited for cultivation in the open ground in the North.

Rhododendron nudiflorum, Torrey, Fl. U.S. 424 (1824); Fl. N. Y.I. 438 (1843). - Gray, Syn. Fl. II. 1, 41 (1878). - J. Robinson, Fl. Essex Co. Mass. 73 (1880). - Dame \& Collins, Fl. Middlesex Co. Mass. 63 (1888). - Britton, Cat. Pl. N. Jersey, 162 (1889). - Dippel, Handb. Laubholzk. I. 414, fig. 267 (1889). - Coulter \& Watson, Gray's Man. ed. 6, 320 (1890).-Dudley \& Thurston, Cat. Pl. Lackawanna \& Wyoming Valleys, 38 (1892). - Beckwith \& Macauley, Pl. Monroe Co. N.Y. 83 (in Proc. Rochester Acad. Sci. III) (1894), in part. - Deane in Rhodora, I. 94 (1899); III. 196 (1901). - Robinson \& Fernald, Gray's New Man. 631 (1908). - Graves \& others, Cat. Flow. Pl. Conn. 308 (1910). -- Schneider, Ill. Handb. Laubholzk. 502, fig. $329 \mathrm{~s}-\mathrm{t}$ (1911).

Azalea lutea Linnaeus Spec. I. 150 (1753), excluding the synonyms of Colden and Gronovius.

Azalea nudiflora Linnaeus, Spec. ed. 2, 214 (1762), excluding the synonyms of Colden and Gronovius. - Wangenheim, Beytr. Forstwiss. 67 (1787). Willdenow, Spec. I. pt. 2, 831 (1798). - Eaton, Man. Bot. ed. 2, 165 (1818). Elliot, Sketch Bot. I. 241 (1821), in part. - Bigelow, Fl. Boston, ed. 2, 82 
(1824). - De Candolle, Prodr. VII. 716 (1839). — Gray, Man. 268 (1848); ed. 5, 299 (1872). - M. A. Curtis, Descript. Trees \& Shrubs, 98 (Geol. Nat. Hist. Surv. N. Car. III. Bot.) (1860). - Willis, Cat. Pl. N. Jersey, 33 (1874). - Kellermann, Cat. Ohio Pl. 129 (in Rep. Geol. Surv. Ohio, VII. pt. 2) (1893), in part. - Britton \& Brown, Ill. Fl. II. 558, fig. 2743 (1897).-Clute, Fl. Upp. Susquehanna, 69 (1898).- Britton, Man. 698 (1901). - Gattinger, Fl. Tennessee, 131 (1901).- Porter, Fl. Pennsylv. 238 (1903). - Small, Fl. S. E. U. S. 883 (1903); in N. Am. Fl. XXIX. 42 (1914). - Shreve \& others, Pl. Life Maryland, 466 (1910). - Stone in Ann. Rep. N. J. State Mus. 1910, 612, t. 95 (1911). - Millspaugh, Liv. Fl. W. Virginia, 323 (in W. Va. Geol. Surv.) (1913). - Schaffner, Cat. Ohio Vasc. Pl. 204 (in Ohio Biol.Surv. I.) (1914), in part. - Taylor, Fl. Vicin. N. Y. 488 (in Mem. N. Y. Bot. Gard. V.) (1915).

Rhododendron venustum Salisbury, Prodr. 287 (1796), in part.

Azalea periclymenoides Michaux, Fl. Bor.-Am. I. 151 (1803). - Pursh, Fl. Am. Sept. I. 152 (1814).

Azalea periclymena Persoon, Syn. I. 212 (1805).

Azalea nudiflora $\beta$. periclymenoides, Heynhold, Nomencl. Bot. Hort. I. 108 (1840).

Anthodendron nudiflorum Reichenbach in Moessler, Handb. Gewächsk. ed. 2, I. $309(1827) .1$

An upright shrub, usually 1 to 2 , rarely to $3 \mathrm{~m}$. tall; young branchlets slightly pubescent and sparingly strigose or nearly glabrous, becoming dull brown or grayish brown; winter-buds brown, glabrous or slightly pubescent, with ovate abruptly acuminate finely ciliate scales; leaves elliptic to oblong or obovate to oblong-obovate, acute or abruptly acuminulate, rarely obtusish, gland-tipped, cuneate at base, 3 to $8 \mathrm{~cm}$. long and 1.5 to $3 \mathrm{~cm}$. wide, finely pubescent on the midrib above, strigillose and sometimes sparingly pubescent on the midrib beneath, finely ciliate on the margins, bright green above and scarcely paler beneath; petioles 2 to $4 \mathrm{~mm}$. long, strigillose and sometimes slightly pubescent. Flowers

1 Preminnean Srnonyms: Azalea scapo nudo floribus confertis terminatricibus staminibus declinatis, Linnaeus, Hort. Cliff. 69 (1737). - Chamaerhododendros Virginiana Periclymeni flore ampliori minus odorato, Duhamel, Traité Arb.I. 160 (1755) and doubtfully Cistus Virginiana Periclymeni flore ampliori et minus odarato [sic] Plukenet, Mant. 49 (1700).

Adpitional Illustrations. Colored Plates: Trew, Pl. Sel. Ehret. t. 48 (1750). - Schmidt, Oester. Baumz. III. t. $170(1800)$, good plate of the typical form. - Bot. Reg. II. t. 120 (1816), as A. nudiflora var. carnea. - Loddiges, Bot. Cab. I. t. 51 (1818), as $A$. nudiflora var. rubra. - Guimpel, Otto \& Hayne, $A b b$. Fremd. Holzgew. t. 110 (1825), apparently var. glandifera with white flowers. Emerson, Trees \& Shrubs Mass. ed. 2, II. 440 t. (1875), pink flowers. - Jour. N. Y. Bot. Gard. XIV. 79, pl. (1913). - House, Wild Fl. N. Y. II. 200, pl. 154 (1920). - Black Figures: Loudon, Arb. Brit. II. 1140, fig. 943 (1838), after Bot. Reg. t. 120. - André, Pl. Terre de Bruyère, 179, fig. 6 (1864). — Gard. XXIX. 550 (1886), same as Loudon's. - Mottet, Dict. Prat. Hort. I. 303, f. 359 (1892), after André. - Newhall, Shrubs N.E. Am. fig. 83 (1893). - Miller \& Whiting, Wild Flow. N. E. St. 379 (1895).-Bailey, Cycl. Am. Hort. I. fig. 172, 173 (1900); Stand. Cycl. Hort. V. fig. 3389, 3390 (1916). - Keeler, Our North. Shrubs, 347 (1903). Stevens, Ill. Guide Flow. Pl., t. 114, fig. 2 (1910). - Rep. N. Jersey St. Mus. 1910, t. 15 (1911). - Amer. For. XXII. 655, fig. (1916). - Habit Figures: Gard. Mag. V. 218, fig. (1907). - Country Life Am. XI. 496 (1907). 
expanding in April and May just before the leaves, scentless or nearly scentlese, $\mathbf{1}$ in 6- to 12-flowered umbel-like racemes; pedicels 0.5 to $1 \mathrm{~cm}$. long, strigose-pilose and sometimes finely pubescent, rarely sparingly glandular; calyx-lobes semi-orbicular or ovate, rarely oblong, 0.5 to $2 \mathrm{~mm}$. long, long-ciliate; corolla usually light pink or whitish with pink tube, funnel-form, tube 1.5 to $2 \mathrm{~cm}$. long, rather gradually dilated above, finely pubescent and pilose or strigose-pilose outside; lobes ovate to oblong-ovate, abruptly acuminate, 1.2 to $1.6 \mathrm{~cm}$. long, finely pubescent outside or glabrescent toward the apex, pilose along the middle; stamens nearly three times as long as the corolla-tube, declinate, the filaments pubescent below the middle; anthers 2 to $2.5 \mathrm{mom}$. long, usually brownish yellow; style 5 to $6 \mathrm{~mm}$. long, somewhat exceeding the stamens, finely pubescent at the lower third, usually purple or purplish above; ovary usually densely covered with long setose glandless hairs, rarely sparingly setose and nearly entirely white-tomentose. Capsule oblong to narrow-oblong, narrowed upward, 1 to $2 \mathrm{~cm}$. long, finely pubescent and usually strigose.

This species has the center of its distribution in the Appalachian mountains from Massachusetts to northwestern North Carolina and ascends to an altitude of $3800 \mathrm{feet}$; its range extends east to the coast from Massachusetts to southern North Carolina and west to central New York (Monroe County), central Pennsylvania, southern Ohio, eastern Kentucky and eastern Tennessee. According to Small it extends into northern Florida, but $I$ have seen no specimens from south of North Carolina. It inhabits chiefly dry open woods and is also found along mountain streams.

Rhododendron nudifiorum in its typical form is chiefly characterized by the glabrous bright green, usually elliptic or obovate leaves pubescent only on the midrib above, strigose along the midrib below and ciliate, by the glabrous winterbuds, by the pink, scentless flowers with a cylindric tube slightly longer than the lobes rather gradually dilated above the middle into the spreading limb and covered outside with a fine pubescence and pilose glandless hairs. The species shows, however, considerable variation and in some forms it approaches $R$. roseum. The most striking variation is that with the hairs of the corolla gland-tipped instead of glandless; this is separated below as a distinct variety. There are slighter variations in the shape of the leaves, in the pubescence of the winterbuds which are sometimes, particularly in the form with glandular corolla, finely pubescent, in the color of the flowers which varies from almost white to deep carmine. The sepals are occasionally well developed as in specimens of var. glandifera from Somerset, Massachusetts, collected by J. G. Jack, May 21, 1903, where they are up to $5 \mathrm{~mm}$. long. In one specimen, Harbison's No. 35 (1919) from Wilmington, North Carolina, the filaments are pubescent beyond the middle and the ovary is only sparingly setose.

Rhododendron nudiflorum was first discovered probably by Banister and mentioned by Plukenet as "Cistus virginiana Periclymeni flore ampliori et minus odarato." It was introduced into England together with $R$. viscosum in the first half of the 18th century, probably between 1725 and 1730 by Peter Collinson, who had received it from John Bartram, for in a letter to Dr. Colden dated Ridge Way House, Feb. 25, 1764, speaking of the plants in his garden he says, "Regard the variety of trees and shrubs in this plantation, as Mountain Magnolia, Sarsifax, Rhododendrons, Kalmias and Azaleas, etc. etc.; all are the bounty of my curious botanic friend, J. Bartram of Philadelphia." 2 According to Aiton it was

${ }^{1}$ Clute (Fl. U pp. Susquehanna, 69), however, calls the flowers very fragrant.

2 Gray, Selections from the Scientific Correspondence of Cadwallader Colden with Gronovius, Linnaeus, Collinson, p. 48 (1843); reprinted from Ann. Jour. Sci. Arts, LXIV. 
introduced in 1734, but Catesby says in 1731 that "it has for several years produced its beautiful and fragrant flowers at Mr. Bacon's at Hoxton and at Mr. Collinson's at Peckham," though it is somewhat doubtful whether the plant referred to is this species or $R$. viscosum or R. canescens, the species figured by Catesby. It is certain, however, that it was in cultivation about 1750 in England, for Ehret's colored plate in Trew, Plantae Selectae Ehretianae (t. 48) is certainly our species, and about 1800 it was known on the Continent, as the excellent colored plate of the typical form in Schmidt's Oesterreichische Baumzucht (III. t. 170) shows. The first detailed description was given in 1787 by Wangenheim, who describes the typical form, for he states that the leaves are glabrous and that the hairs on the outside of the corolla-tube have no glands; he also mentions two pubescent varieties and a form which he saw only cultivated in two gardens in the state of New York with fringed or erose corolla-lobes.

The nomenclature of the species presents some difficulties discussed by Blake in Rhodora (XX. 53 [1918]). The oldest name for the species is A. lutea Linnaeus, of which $A$. nudiflora is merely a synonym, but fortunately the name lutea cannot be transferred to Rhododendron on account of the older $R$. luteum Sweet which is the valid name of $A$. pontica Linnaeus under Rhododendron. Therefore the synonym A. nudiflora takes the place of A. lutea. Those, however, who retain Azalea as a distinct genus must, as pointed out by Blake, either adopt $A$. lutea for the pink-flowered species or discard altogether both $A$. lutea and $A$. nudiflora and adopt Michaux's $A$. periclymenoides.

The form with pink or pinkish flowers should be considered the type of this species ${ }^{1}$; it seems to be the most common and the one originally cultivated under this name, as Trew's plate of 1750 which shows pink flowers tends to prove. The form with white or nearly white flowers may be distinguished as f. album. ${ }^{2}$ Most of the more highly colored forms probably belong to var. glandiferum, though this variety also includes light colored forms.

1 This is probably the form distinguished as:

Rhododendron nudiflorum $\delta$. carneum Sweet, Hort. Brit. ed. 2, 343 (1830). G. Don. Gen. Syst. III. 847 (1834).

Azalea nudiflora $\gamma$. carnea Aiton, Hort. Kew. I. 202 (1789). - Ker in Bot. Reg. II. t. 120 (1816). - De Candolle, Prodr. VII. 717 (1839).

? Azalea carnea Dumont de Courset, Bot. Cult. III. 332 (1811), as var. of $A$. nudiflora.

Azalea periclymenoides $\boldsymbol{\gamma}$. carnea Pursh, Fl. Am. Sept. 152 (1814).

Ker's figure and description represent apparently the typical pink-flowered form of $\boldsymbol{R}$. nudiflorum with pilose corolla and nearly smooth leaves; but it differs from the original description in the calyx, which is described as foliaceous by Aiton, while Ker calls it small. Dumont de Courset describes the leaves as pubescent, which would remove his plant from $R$. nudiflorum.

2Rhododendron nudiflorum a. album Sweet, Hort. Brit. ed.2, 343 (1830). - G. Don, Gen. Syst. III. 847 (1834), as var. $\delta$.

Azalea nudiflora $\delta$. alba Aiton, Hort. Kew. I. 202 (1789).

Azalea alba Dumont de Courset, Bot. Cult. ed. 2, III. 332 (1811), as var. of A. nudiflora. - Michaux, Jour. ed. C. S. Sargent, 111 (in Proc. Am. Philos. Soc. XXVI (1899).

Dumont de Courset's description of the tube of the corolla as covered with short hairs and of the scales of the winter-buds as glabrous shows that a form of typical $\boldsymbol{R}$. nudiflorum was cultivated under that name. 
Rhododendron nudiflorum var. glandiferum Rehder, comb. nov.

Azalea nudiflora glandifera Porter in Bull. Torr. Bot. Club, XXVII. 508 (1900); Fl. Pennsylv. 238 (1903). - Keller \& Brown, Handb. Fl. Phila. 246 (1905). Stone in Ann. Rep. N. Jersey State Mus. 1910, 613 (1911).

This variety differs from the type in having the pedicels and the outside of the corolla-tube furnished with more or less numerous gland-tipped hairs of usually nearly equal length, and the color of the corolla is usually of a deeper pink or carmine color. The variety was based originally on specimens collected in eastern Pennsylvania, but it is found frequently within the range of the type from Massachusetts to northwestern South Carolina and often grows together with the typical form. It seems, however, nearly absent from the southeastern part of the range, that is from the coastal plain from New Jersey to North Carolina and more common West, for the plants I have seen from the extreme Western localities, western Tennessee and southern Ohio, represent this variety though from the last named locality (Lawrence County) and from western New York (Monroe County) I have seen specimens of the typical form.

A form with double flowers is mentioned by Pursh (Fl. Am. Sept. 152 [1814]) under his $A$. periclymenoides, but he does not state where he saw it. In 1826 Sweet enumerated a double white form (Azalea nudiflora $\beta$. albo-plena Sweet, Hort. Brit. 265 [1826]), name only. - Rhododendron nudiflorum $\beta$. albo-plenum Sweet, Hort. Brit. ed. 2, 343 (1830) and a semi-double white form (Azalea nudiflora $v \nu$. semiduplex Sweet, Hort. Brit. 265 [1826]. - Rhododendron nudiflorum vv. semiduplex

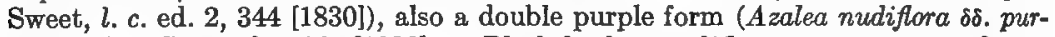
pureo-plena Sweet, l. c. 265 [1826]. — Rhododendron nudiflorum $\delta \delta$. purpureo-plenum Sweet, l. c. ed. 2, 344 [1830]) and a double red form (Azalea nudiflora кк. rubroplena Sweet, l. c. 265 [1826]. - Rhododendron nudiflorum кк. rubro-plenum Sweet, l. c. ed. 2, 344 [1830]). Probably Azalea nudiflora flore pleno Loddiges Cat. 1836 (ex Loudon, Arb. Brit. II. 1142 [1838]) is the same as the double white form of Sweet. Two different forms Azalea periclymenoides "alba pleno" and "rubra pleno" were offered in 1831 by R. Carr (Cat. Am. Trees Bartram Bot. Gard. 64). All the double-flowered forms in cultivation which $I$ have seen seem to be of hybrid origin, but from Kew Gardens I have seen a specimen collected by G. Nicholson in 1880 as Azalea "Double Blush" which is probably a doubleflowered $R$. nudiflorum; it has the leaves perfectly glabrous beneath except the strigose midrib and the corolla is pilose and villose outside but not glandular.

Several other varieties and forms have been described or mentioned by Aiton, Loddiges and others, but as the descriptions are inadequate and I have not seen the type specimen or other reliable material of them, I am in doubt whether they belong here or to $R$. roseum or to $R$. canescens; they will therefore be enumerated under the doubtful names.

Rhododendron roseum Rehder, comb. nov.

Azalea rosea Loiseleur-Deslongchamps in Duhamel, Traité Arb. Arbust. ed. 2, V. 224, t. 64 (1812). - ? Michaux, Journal, ed. C. S. Sargent, 111 (in Proc. Am. Philos. Soc. XXVI. (1889)).

1 Azalea nudiflora rubra Loddiges, Bot. Cab. I. t. 51 (1817). - De Candolle, Prodr. VII. 717 (1839), as var. - Rhododendron nudiflorum var. rubmum Sweet, Hort. Brit. ed. 2, 343 (1830); G. Don, Gen. Syst. III. 847 (1834) is probably identical with this variety, judging from Loddiges' figure, but as long as one cannot be positively sure I prefer to keep Porter's name. 
Azalea canescens Pursh, Fl. Am. Sept. I. 152 (1814), in part, as to the specimen from Virginia, ${ }^{1}$ not Michaux. - Eaton, Man. Bot. 165 (1818). — Britton \& Brown, Ill. Fl. II. fig. 2744 (1897). - Clute, Fl. Upp. Susquehanna, 70 (1898). - Britton, Man. 698 (1901). - Porter, Fl. Pennsylu. 238 (1903). Millspaugh, Liv. Fl. W. Virginia, 322 (in W. Va. Geol. Surv.) (1913).House, Wild Fl. N. Y. II. 201 (1920), excl. figure.

Azalea nudiflora єє. rosea Sweet, Hort. Brit, 265 (1826), name only.-Loddiges apud Loudon, Arb. Brit. II, 1142, fig. 945 (1838), name and figure only.

?Azalea calendulacea $\delta$. cupraea Sweet, Hort. Brit. 265 (1826), name only.Loddiges, Bot. Cab. XIV. t. 1394 (1828).

?Rhododendron calendulaceum $\delta$. cupreum Sweet, Hort. Brit. ed. 2, 343 (1830), name only.

Rhododendron nudiflorum єє. roseum Sweet, Hort. Brit. ed. 2, 344 (1830).

Rhododendron nudiflorum Darlington, Fl. Cestrica, ed. 2, 262 (1837), not Torrey. ${ }^{2}$ - Oakes, Cat. Vermont Pl. 190 (in Thompson, Hist. Vermont) (1842); reprint p. 18 (1842). - Dudley, Cayuga Fl. 59 (in Bull. Cornell Univ. II.) (1886). - Perkins, Cat. Fl. Vermont, 33 (1888). - Beckwith \& Macauley, Pl. Monroe Co. N. Y. 83 (in Proc. Rochester Acad. Sci. III.) (1894), in part.

Azalea nudiflora Darlington, Fl. Cestrica, 26 (1826). ${ }^{2}$ - Wright \& Hall, Cat. Pl. Troy, 8 (1836). - Clinton, Prelim. List Pl. Buffalo, 7 (1864). - Payne, Cat. Pl. Oneida Co. 51 (in Rep. Regents Univ. N. Y.) (1865). - Patterson, Cat. Pl. Illinois, 25 (1876). - D. F. Day, Pl. Buffalo, 115 (in Bull. Buffalo Nat. Sci. IV.) (1882), - Meehan in Meehan's Monthly, II. 17, t. 2 (1892). ${ }^{3}$ Kellerman, Cat. Ohio Pl. 129 (in Rep. Geol. Surv. I.) (1914), in part. Schaffner, Cat. Ohio Vasc. Pl. (in Ohio Biol. Surv. I.) (1914), in part.

Rhododendron canescens Porter in Bull. Torr. Bot. Club XVI. 220 (1889), not Sweet. - Dudley \& Thurston, Cat. Pl. Lackawanna \& Wyoming Valleys, 38 (1892). - Deane in Rhodora, III. 196 (1901). - Fernald \& Robinson, Gray's New Man. 631 (1908).- Jackson, Cat. Pl. Worcester Co. Mass. 76 (1909). - Graves \& others, Cat. Flow. Pl. Conn. 308 (1910). - Stone, List Pl. Frankl. Hampshire, Hampden Cos. Mass. 48 (1913). - Rehder in Bailey, Stand.Cycl.Hort. V. 2942 (1916). - Twining, Fl. N. E. Pennsylv. 56 (1917).

Azalea prinophylla Small in N. Am. Fl. XXIX. 42 (1914). - Taylor, Fl. Vicin. N. Y. 488 (in Mem. N. T. Bot. Gard. V.) (1915).

Rhododendron prinophyllum Millais, Rhodod. 229 (1917). - Millais \& Williams in Rhodod. Soc. Notes, I. 125 (1918).4

A shrub 1 to 3 , rarely to $5 \mathrm{~m}$. tall, with irregularly whorled branches; the young branchlets finely pubescent, and usually sparingly strigose, becoming grayish brown or light brown the second year; buds grayish pubescent with numerous,

1 The phrase in the description "staminibus vix exertis" also refers to $R$. roseum rather than $R$. canescens.

${ }^{2}$ As the leaves are described as pubescent beneath, the species must be $R$. roseum rather than $R$. nudiflorum.

${ }^{3}$ As Meehan describes the leaves as pubescent beneath and the corolla as glandular, the plant figured must be $R$. roseum rather than $R$. nudiflorum.

- Adpitional Illudstrations. Colored Plates: Goodale, Wild Flow. Am. t. 36 (1882). - Meehan's Monthly, II. t. 2 (1892). - Black Figures: Loudon, Arb. Brit. II. fig. 945 (1838), as R. nudiflorum var. rosea, after Nouv. Duhamel. Keeler, Our North. Shrubs, 349, fig. (1903), as Azalea canescens. - Stevens, Ill. Guide Flow. Pl. t. 114, fig. 1 (1910), as A. canescens. 
generally ovate, obtusish and mucronulate scales. Leaves elliptic or obovate to obovate-oblong, acute or short-acuminate, gland-tipped, cuneate at the base, 3 to $7 \mathrm{~cm}$. long and 1.2 to $3.3 \mathrm{~cm}$. broad, sparingly pubescent above, densely grayish villose beneath or sometimes thinly villose rarely nearly glabrous except along the midrib, sparingly strigillose on the midrib, ciliolate, thinnish at maturity, usually more or less bluish green or dull green; petioles 2 to $5 \mathrm{~mm}$. long, soft-pubescent and sparingly strigose. Flowers expanding in May with the leaves in usually 5- to 9flowered umbel-like racemes, fragrant; pedicels 0.5 to $1.5 \mathrm{~cm}$. long, finely villose and glandular-setose; calyx-lobes semiorbicular to ovate, unequal, scarcely exceeding $1 \mathrm{~mm}$., finely pubescent, glandular-ciliate; corolla funnel-form with oblique limb, usually bright pink, rarely whitish, the tube 1.5 to $2 \mathrm{~cm}$. long, cylindric, rather gradually dilated toward the apex, covered with a thin villose tomentum interspersed with numerous gland-tipped hairs of unequal length, pubescent inside, the lobes about as long or slightly shorter than tube, ovate, abruptly pointed; stamens little more than twice as long as tube, filaments pubescent below the middle, the anthers about $2 \mathrm{~mm}$. long, ochraceous; style exceeding the stamens, 4 to $5 \mathrm{~cm}$. long, sparingly or sometimes rather densely pubescent below, purple above; ovary finely covered with a villous pubescence overlaid with numerous appressed white, setose, partly gland-tipped hairs. Capsule oblong, narrowed toward the apex, 1.5 to $2 \mathrm{~cm}$. long, sparingly puberulous and setosely glandular.

Rhododendron roseum is distributed from southwestern New Hampshire, central Vermont and southwestern Quebec ${ }^{1}$ through western New York, eastern Ohio, southern Illinois to southeastern Missouri, and through western and central Massachusetts, northwestern Connecticut, northern Rhode Island, New York, Pennsylvania, and northern New Jersey to southwestern Virginia and western Tennessee. Its range lies chiefiy west of the Appalachian Mountains, except in the north, and does not extend into the coastal plain.

This species is closely related to $R$. nudiflorum and particularly to its variety glandiferum and I was for some time inclined to refer it as a variety to the latter species, as it seems to be connected with it by intermediate forms. It differs, however, in several important characters from typical $R$. nudiflorum, as in the pubescent winter-buds, the more or less densely villous branchlets, the pubescent bluish-green leaves, in the shorter stamens and in the glandular corolla with larger and broader lobes and a wider tube, and as the two are easily distinguished in their typical forms, I think it better to keep them as distinct species. Glabrescent forms with the leaves pubescent only along the midrib might be confused with $R$. nudiflorum, but can be distinguished from it by the flowers, the pubescent winter-buds and the finely villous branchlets. Rhododendron roseum has also been confused with $\boldsymbol{R}$. canescens Don, with which it agrees in the pubescence of the leaves, but differs in the shorter, gradually dilated pilose-glandular corolla-tube, in the shorter stamens and in the thinner, not reticulate leaves.

This species was first mentioned in 1787 as a variety of Azalea nudiflora "with broad rough leaves" by Wangenheim (Beytr. Forstwiss. 68), who observed it in the state of New York. When it was introduced into cultivation cannot be stated with certainty. It may be one of the varieties mentioned by Aiton in 1789, and without doubt Pursh's specimen from Cacapoon Springs near Winchester, West Virginia, referred by him to $R$. canescens belongs here. According to a note by Loudon (Arb. Brit. II. 1143) this has been found in Virginia "on the mountains of the Cacapoon Springs, near Winchester, where it forms a shrub growing 3 feet or 4 feet high and producing its rose-coloured flowers in May and June. Introduced in 1812 and

1 Near Hull, Quebec, June 5, 1916, John Dunbar (Herb. Park Dept., Rochester, N. Y.) 
cultivated in several of the London nurseries." Loddiges states under A. calendulacea cuprea, which possibly belongs to this species, that it was introduced in 1806 by John Lyon. It must have been in cultivation in Europe before 1812, for I have little doubt that Loiseleur's description and figure in the Nouveau Duhamel represents this species, though he himself identifies it with $A$ zalea canescens Michx. by quoting that name as a synonym. The colored plate in Nouveau Duhamel well shows its difference from $R$. canescens in the dense flower-cluster, the bright rosypink corolla, its wide limb and short tube furnished with conspicuous glandular hairs, the comparatively short stamens and the bluish green leaves. Loiseleur's figure and name, however, have been entirely overlooked by later authors, and after Pursh had described it as $A$. canescens, the species was not mentioned again, until Porter described it in 1889 , clearly pointing out its difference from $R$. nudiflorum and from $R$. calendulaceum; but he also referred it to Azalea canescens Michx., naming it $R$.canescens (Michx.). As a distinct species it was recognized by Small, who described it in 1914 as A. prinophylla in the North American Flora, overlooking the name $A$. rosea, which is not enumerated in the Index Kewensis nor mentioned in any systematic work after 1812 .

\section{Rhododendron alabamense Rehder, spec. nov.}

Azalea nudiflora var. alba Mohr, Pl. Life Ala. 653 (1901), not Pursh.

Frutex humilis ramis subverticillatis; ramuli juniores satis dense vel sparse pallide strigoso-pilosi, annotini griseo- vel flavido-brunnei; vetustiores plerique fusco-brunnei; gemmae florales multiperulatae perulis ovatis apice rotundatis mucronatis glabris fuscis margine dense albo-ciliolatis. Folia obovata vel elliptica ad elliptico-oblonga $\nabla$. obovato-oblonga, acuta vel obtusiuscula et glandulosomucronulata, basi cuneata, 3-6 cm. longa et 1.4-3 cm. lata, supra initio sparse vel sparsissime villosula et saepe minute strigillosa; subtus glaucescentia vel pallida et tota facie satis dense villosula, costa media supra villosula subtus pleraque sparse strigosa, margine ciliata, utrinque nervis 10-12; petioli villosuli et strigillosi, breves. Flores odorati, simul cum foliis, mense Aprili et Maio; plerumque 6-10, subumbellati; pedicelli $0.5-1 \mathrm{~cm}$. longi, sparse villosuli et plerique satis dense hirsutis pilis partim glanduliferis vel eglandulosis; sepala inaequalia, semiorbicularia ad ovata, 0.5-1.5 mm. longa, extus et margine pilis longis setosis eglandulosis instructa; corolla infundibuliformis, alba, tubo cylindrico apice sensim dilatato, 2-2.8 cm. longo, rarius breviore, extus sparse villosula et plus minusve pilosis pilis partim glanduliferis vel interdum omnibus eglandulosis et longioribus, lobis ovatis acutis circiter 1.5 vel fere $2 \mathrm{~cm}$. longis, tubo manifeste brevioribus, stamina tubum duplo superantia, vix declinata, filamentis infra medium villosis albidis, antheris flavidis $2-3 \mathrm{~mm}$. longis; stylus stamina longiora vix superans, $5-6 \mathrm{~cm}$. longus, basin versus villosulus, albidus; ovarium dense setoso-strigosum setis glandulosis vel fere eglandulosis. Capsula (immatura) cylindrico-oblonga, circiter $1.5 \mathrm{~cm}$. longa, sparse villosula et glandulosa vel fere eglandulosa.

Low shrub with irregularly whorled branches; young branchlets densely or sparingly furnished with pale strigose hairs; one-year old branchlets grayish or yellowish brown, older branches usually dark brown; floral winter-buds glabrous, brown, of many ovate scales rounded and mucronate at apex, densely whiteciliolate. Leaves obovate or elliptic to elliptic-oblong or obovate-oblong, acute or obtusish and gland-tipped, cuneate at base, 3 to $6 \mathrm{~cm}$. long and 1.4 to $3 \mathrm{~cm}$. wide, above sparingly or very sparingly puberulous and of ten finely strigillose, glaucescent or sometimes pale green beneath and usually rather densely, sometimes more sparingly short-villose, the midrib villose above and usually sparingly strigose beneath, ciliate on the margin, with 10 to 12 pairs of veins; petioles finely villose and strigil- 
lose, short. Flowers fragrant, appearing with the leaves, in April and May, in usually 6- to 10 -flowered umbel-like clusters; pedicels 0.5 to $1 \mathrm{~cm}$. long, sparingly villose and rather densely hirsute, glandless or glandular; sepals unequal, roundish to ovate, 0.5 to $1.5 \mathrm{~mm}$. long, densely setose, glandless; corolla funnel-form, white, tube cylindric, gradually dilated at apex, 2 to $2.8 \mathrm{~cm}$. long, rarely slightly shorter, outside sparingly and more or less glandular-pilose or sometimes hirsute without glands, lobes ovate or sometimes ovate-oblong, acute, 1.5 to $1.8 \mathrm{~cm}$. long, distinctly shorter than the tube; stamens twice as long as tube, scarcely declinate, the filaments villose below the middle, the anthers yellowish, 2 to $3 \mathrm{~mm}$. long; style Bcarcely exceeding the longer stamens, 5 to $6 \mathrm{~cm}$. long, finely villose toward the base, whitish; ovary densely setose-strigose, glandular or nearly glandless. Capsule (immature) cylindric-oblong, about $1.5 \mathrm{~cm}$. long, sparingly and finely villose and glandular-setulose or nearly glandless.

Alabama. Cullman County : Pine woods, May 21, 1902, Biltmore Herb. H/6292 ${ }^{1}$ (Nat. Herb. No 980,507, type); on rocky slope in woods of Oak, Hickory and Pine, May 21, 1902, Biltmore Herb. H/6293 (Nat. Herb. No. 980,506); dry rocky hillside, May 19, 1902, Biltmore Herb. H/6258 (Nat. Herb. No. 980,524); dry woods, May 19, 1902, Biltmore Herb. H/6267, 6268 (Nat. Herb. Nos. 980,528, 980,511); without special locality, May 19, 1902, Biltmore Herb. H/6259, 62626265 (Nat. Herb. Nos. 980,525, 980,510, 980,523, 980,509, 980,527); dry rocky open woods on the high tablelands, May 2, 1883, C. Mohr (as $R$. (Azalea) nudiflora alba; "flowers snowy white, highly fragrant"). Marshall County: Albertville, May 8, 1901, Biltmore Herb. H/4290, 4292, 4293, 4295, 4297 (Nat. Herb. 969,632, 969,628, 969,682, 969,634, 969,658); dry woods, August 27, Biltmore Herb. H/2452 (Nat. Herb. 969,617); October 12, 1900, Biltmore Herb. H/3321 (Nat. Herb. 969,649). Henry County : Abbeville, April 15, 1902, Biltmore Herb. H/6112 (Nat. Herb. 980,513).

As it appears from these specimens this species is known to me only from two counties in northern and from one county in southeastern Alabama, but probably it is more widely distributed through the northern and central part of the state; it iahabits dry open woods and rocky hillsides and thus agrees in its habitat with the northern $\boldsymbol{R}$. roseum, while $\boldsymbol{R}$. canescens, the other common Alabama species, prefers damp woods and swamps.

This new species is closely related to $R$. nudiflorum Torr., $R$. roseum Rehd. and $R$. canescens G. Don. From the first species it is easily distinguished by the much longer and slenderer corolla-tube, the pure white fragrant flowers, less longexserted scarcely declinate stamens and the pubescent leaves; from $R$. roseum it differs in the glabrous winter-buds, the longer and slenderer corolla-tube, the glandless setae of the sepals, in the white color of the flowers and in the glaucescent under side of the leaves; from $R$. canescens it is distinguished by the glabrous winter-buds, the much less villose and more or less pilose corolla-tube, less slender and more gradually dilated at the apex, by the less exserted stamens, the larger limb, the densely strigose ovary, the less villose and more setose capsules,

1 "H" stands for T. G. Harbison who collected for the Biltmore Herbarium. 
and the generally broader leaves. Rhododendron alabamense shows some variation chiefly in the size and pubescence of its flowers. The type specimen has large flowers with a glandular-pilose tube, while in Nos. 6258 and 6259 the tube has longer and quite glandless hairs; the specimens from Albertville have generally smaller flowers, the tube sometimes scarcely $2 \mathrm{~cm}$. long and the lobes longer and narrower, sometimes nearly oblong and acuminate, the leaves are also smaller and less glaucescent and often less pubescent beneath. The Abbeville specimen from southeastern Alabama is again much like the type in its flowers, but the leaves are less densely pubescent and less glaucescent beneath. In the National Herbarium is a sheet (No. 770,587) labeled " $R$. viscosum Torr., borders of stream in thickets, Pointelear (not quite legible), C. Mohr, June 16, 1889," which contains a specimen of $R$. arborescens and two specimens which suggest a glabrous form of $R$. alabamense, but as apparently the locality and the date do not belong to these two specimens, I consider them for the present as doubtful.

Rhododendron alabamense was apparently first observed in 1883 by Dr. C. Mohr, who recognized it as distinct from the more widely distributed $R$. canescens which he included under his $A$. nudiflora; this probably induced him to identify this particular form with $A$. nudiflora var. alba Aiton. The species has not yet been introduced into cultivation; it may be hardy North, and for southern gardens it would be superior to $R$. canescens on account of its very fragrant larger flowers, which are "snowy white" according to Dr. Mohr.

Rhododendron canescens Sweet, Hort. Brit. ed. 2, 343 (1830). G. Don, Gen. Syst. III, 848 (1834), excl. the reference to plant of Winchester. - Loudon, Arb. Brit. II, 1143 (1838), in part. - Millais, Rhodod. 136 (1917).

Azalea lutea Linnaeus, Spec. 150 (1753), as to the synonym of Gronovius only. Azalea nudiflora Linnaeus, Spec. ed. 2, 214 (1762), as to the synonym of Gronovius only. - Walter, Fl. Car. 97 (1788). - Elliott, Sketch Bot. I. 240 (1821), in part. - Mohr, Pl. Life Ala. 653 (1901).

$?$ Azalea nudiflora $\epsilon$. bicolor Aiton, Hort. Kew. I. 203 (1789).

Azalea canescens Michaux, Fl. Bor.-Am. I. 150 (1803). - Pursh, Fl. Am. Sept. 152 (1814), in part. - Elliott, Sketch Bot. I. 239 (1821). - De Candolle, Prodr. VIII. 717 (1838). - Small, Fl. S. E. U. S. 883 (1903); Shrubs Fla. 93 (1913); in N.Am. Fl. XXIX. 42 (1914).

Azalea bicolor Pursh, Fl. Am. Sept. I. 153 (1814). - Elliott, Sleetch Bot. I. 239 (1821). - De Candolle, Prod. VII. 717 (1839).

Rhododendron bicolor Sweet, Hort. Brit. ed. 2, 344 (1830). - G. Don, Gen. Syst. III. 847 (1834). - Loudon, Arb. Brit. II. 1142 (1838).

Rhododendron nudiflorum Chapman, Fl. S. U. S. 265 (1865), not Torrey.

Azalea nudiflora var. canescens Rehder in Bailey, Cycl. Am. Hort. I. 121 (1900), in part.1

A shrub to 4 or $5 \mathrm{~m}$. tall with irregularly whorled upright branches; young branchlets finely villous-pubescent and usually sparingly strigose; winter-buds with broadly ovate, acuminulate and densely grayish pubescent scales. Leaves usually

- Preminnenn Srnonym: Cistus Virginiana flore et odore Periclymeni, Catesby, Nat. Hist. Car. I. 57, t. 57 (1731), not Banister apud Plukenet.

Addrional Illugtrations. Coloned Plates: Abbot, Nat. Hist. Lepidopt. Georgia, I. t. 27 (1797). - Audubon, Birds of Am. IV. t. 398 (1835-38). 
oblong-obovate to oblanceolate or oblong, rarely elliptic or obovate, acute, rarely obtusish, gland-tipped, cuneate at base, 4 to $9 \mathrm{~cm}$. long and 1.5 to $3.5 \mathrm{~cm}$. broad, setosely ciliate, sparingly pubescent above or glabrescent except at the finely vilJose midrib, densely pubescent or grayish tomentulose beneath particularly on the veins and midrib, usually sparingly strigose on the midrib toward the base, of firm texture and slightly reticulate beneath at maturity; petioles 2 to $7 \mathrm{~mm}$. long, finely pubescent and sparingly strigose. Flowers expanding before or with the leaves in April and May, in 6- to 15-flowered clusters, slightly fragrant; pedicels 0.5 to $1 \mathrm{~cm}$. long, villose-pubescent and hirsute, sometimes stipitate-glandular; calyx-lobes, unequal, semi-orbicular to ovate, scarcely exceeding $1 \mathrm{~mm}$., ciliate or sometimes glandular-ciliate; corolla-tube cylindric, abruptly dilated at apex, 1.5 to $2.3 \mathrm{~cm}$. long, distinetly longer, sometimes nearly twice as long as lobes, densely and finely villose outside and stipitate-glandular, rarely somewhat pilose, pubescent inside; lobes ovate, acute or obtusish, 1.2 to $1.5 \mathrm{~cm}$. long; stamens much exserted, nearly 3 times as long as tube, pubescent below the middle, anthers 1.5 to $2 \mathrm{~mm}$. long, ochraceous; style 4 to $6 \mathrm{~cm}$. long, finely villose toward the base, slightly longer or about as long as stamens; ovary densely white pubescent with appressed silky hairs and sparingly setulose, without glands. Capsule cylindric-oblong, narrowed upward, slender, 1.5 to $2 \mathrm{~cm}$. long, pubescent and sparingly setose.

This species is chiefly a plant of the southern Atlantic and the Gulf coastal plain, but extends into the Piedmont region of North Carolina, Georgia and Tennessee; it ranges from southwestern Tennessee and southern central North Carolina to eastern South Carolina and northeastern Florida to extreme southeastern Texas, central Louisiana and northeastern Alabama. It usually grows in woods on moist sandy soil, often along streams, rarely in swampy soil.

Rhododendron canescens is chiefly characterized by the more or less pubescent leaves firm at maturity and slightly reticulate beneath, by the slender corolla-tube abruptly enlarged into a comparatively small limb and clothed outside with a fine dense villose tomentum interspersed with rather short and small stipitate glands, by the long exserted stamens being nearly three times as long as the tube and by the grayish pubescent eglandular and not strongly setose ovary and capsule. The color of the flowers is usually pink or perhaps more often the tube only is pink and the limb white or only slightly pinkish; a form with nearly purple flowers differing further from the type in the comparatively short and wide corollatube has been collected by T. G. Harbison at Valleyhead, Alabama (No. 530; May 2, 1911). There is considerable variation in the pubescence of the leaves; in one extreme they are nearly white tomentose beneath, while in the other extreme they are nearly glabrous. The glabrous or glabrescent form has been confused with $R$. nudiflorum, but it is easily distinguished from that species by the shape and pubescence of the corolla and by the pubescent winter-buds.

Rhododendron canescens was discovered by Catesby, who published a characteristic and fairly good figure of it in 1731. In 1797 an excellent colored plate of it, drawn by J. Abbot, was published as $A$. nudiflora in his work on the Lepidopterous insects of Georgia. It was also collected by Michaux in South Carolina between 1784 and 1796, and first recognized by him as a distinct species and described in his Flora as $R$. canescens. Pursh in 1814 confused Michaux's $A$. canescens with $R$. roseum; he identified a plant collected near Winchester, West Virginia, which apparently was $R$. roseum, with Michaux's $A$. canescens and redescribed the true $A$. canescens under the name $A$. bicolor.

It was probably introduced into cultivation about the middle of the 18th century and it may be one of the varieties enumerated by Aiton in 1789 and possibly his var. bicolor, cited by Pursh as a synonym of his $A$. bicolor which is identical with $\boldsymbol{R}$. canescens, but it apparently soon disappeared again from the gardens. 


\section{Rhododendron canescens f. subglabrum Rehder, forma nov.}

A typo recedit foliis costa media utrinque villosa et margine ciliato exceptia subglabris; ceterum ut in typo.

Mississippi. Hinds County : Jackson, April 15 and 30, 1915, T. G. Harbison (No. 16, type, No. 38). Tishomingo County: Iuka, May 5, 1915, T. G. Harbison (No. 6). Lauderdale County: Meridian, April 12, 1900, C.S. Sargent; April 16, 1915, T.G. Harbison (Nos. 5, 13). Harrison County: Mississippi City, March 31, 1900, C. S. Sargent.

Georgia. Habersham County: Cornelia, bank of small stream, May 6, 1920, T. G. Harbison (No. 40). Randolph County: Cuthbert, pine woods, March 29, 1918, T. G. Harbison (No. 19, low shrub).

Alabama. Cullman County: May 3, 1901, Biltmore Herb. H/4246 (Nat. Herb. 969,666). Chilton County: Mapleville, April 13, 1912, T. G. Harbison (No. 849). Dallas County: Selma, April 9, 1912, T. G. Harbison (No. 825). Lee County: Auburn, April 6 and 8, 1913, T. G. Harbison (Nos. 817, 807). Mobile County: Mobile, March 18, 1894, C. Mohr.

Louisiana. Natchitoches Parish: Natchitoches, wet sandy banks, April 15, 1915, E. J. Palmer (No. 7228). Calcasieu Parish: Lake Charles, April 2, 1913, C. S. Sargent. East Baton Rouge Parish : Baton Rouge, April 15, 1920, R. S. Cocks (No. 3321).

Texas. Hardin County: Fletcher, March 17, 1918, E. J. Palmer (No. 13,095, in part).

This form differs from the type in its glabrescent or nearly glabrous leaves; they may be either glabrous on both sides except the ciliate margin and the midrib which is finely villous above and beneath and often also sparingly strigillose beneath, or sometimes they are finely pubescent on the upper surface while young and rarely also sparingly pubescent beneath. In the pubescence of the winterbuds, of the branchlets and of the flowers, this form does not differ from the type and is thus easily distinguished from $R$. nudiflor

This form is distributed from northern and western Georgia through Alabama to northeastern Mississippi, western Louisiana and southeastern Texas, and south to the coast of Alabama, Mississippi and Louisiana. Its range lies wholly within the range of the type, but is apparently chiefly restricted to the western portion of it. The only stations known to me east of Alabama are near Cuthbert, Randolph County, in western, and near Cornelia, Habersham County, in northeastern Georgia. It has been usually confused with $R$. nudiflorum, and the extension of the range of $R$. nudiflorum beyond Tennessee and South Carolina given in those floras which keep $R$. nudiflorum distinct from $R$. canescens refers apparently to this form. It is connected by intermediate forms with the type and generally the pubescence on the leaves of specimens of the type from the western part of the range of the species is much thinner than that of the eastern specimens.

Rhododendron canescens f. subglabrum has only recently been introduced into cultivation through the Arnold Arboretum, where it was raised from seed sent by E. J. Palmer in 1916 from Fletcher, Texas. It will probably not be hardy in the northern states and does not differ from the type in its ornamental qualities. 


\section{Rhododendron canescens var. candidum Rehder, var. nov.}

Azalea candida Small in Bull. Torr. Bot. Club XXVIII. 360 (1901); Fl. S. E. U. S. 883 (1903); Shrubs of Fla. 93 (1913); in N.Am. Fl. XXIX. 43 (1914).

Rhododendron candidum Rehder in Bailey, Stand. Cycl. Hort. V. 2945 (1916); VI. 3574 (1917). - Millais, Rhodod. 136 (1917).

This variety differs from the typical form in the glaucous or glaucescent, densely pubescent under side of the leaves and in the mostly denser pubescence of the branchlets usually interspersed with numerous short gland-tipped setae. The white or whitish color of the under side is not caused by the dense tomentum, as one might suppose, but by the glaucous or glaucescent epidermis, which is coated with a waxy exudation as in glaucous forms of $R$. viscosum.

Georgia. Decatur County: Climax, Nov. 6, 1917, T. G. Harbison (No. 14). Brooks County: Quitman, April 2, 1918, T. G. Harbison (No. 3). Low ndes County : near Valdosta along the Withlacoochee River, June 6-12, 1895, J.K. Small (type); in low sandy soil along the Withlacoochee River, April 2, 1918, T. G. Harbison (Nos. 1, 2); near Ousley, Oct. 21, 1910, T. G. Harbison (Nos. 247, 250). Charlton County : Folkston, July 16, 1918, T. G. Harbison (No. 76). Tattnall County : rock outcrop near Choopee River, June 24, 1903, R. M. Harper (No. 1858).

Florida. Hamilton County: White Springs, May 11, 1901, H. H. Blume.

This variety is restricted to southern Georgia and northern Florida and I have seen no specimen farther north or south than about twenty miles from the border line except a specimen from Tattnal County about one hundred miles north of Florids, but that specimen is not a typical var. candidum, as it lacks the glandular pubescence of the branchlets, and the under side of the leaves though densely villous or almost whitish tomentose, is not very glaucous. Besides the character already mentioned $I$ can find no difference between this variety and $R$. canescens and $I$ therefore pre fer to consider it only a variety of that species. I do not understand why Small places it among the species with the flowers appearing after the leaves; the flowering specimens before me, collected April 2, differ in no way as regards the development of leaves from typical $R$. canescens.

The variety seems to have been first observed and collected in 1895 by Dr. Small on the Withlacoochee River. It is doubtful whether it is in cultivation; the plant introduced under this name a few years ago raised from seed collected near Folkston, Georgia, is possibly typical $R$. canescens.

Rhododendron austrinum Rehder in Bailey, Stand. Cycl. Hort. VI. 3571, 3574 (1917). - Millais, Rhodod. 125 (1917).

Rhododendron nudiflorum var. luteum Curtiss in herb. sub No. 1718.

Azalea austrina Small, Fl. S. E. U. S. ed. 2, 1356 (1913); Shrubs Fla. 94 (1913); in N. Am. Fl. XXIX. 42 (1914).

Slender branched shrub to $3 \mathrm{~m}$. tall; young branchlets covered with a short soft pubescence interspersed with usually copious gland-tipped hairs and sparingly strigose, particularly toward the apex, becoming red-brown in autumn and grayish brown the second year; floral winter-buds with ovate scales, rounded to 
acutish and acuminulate at the apex and densely grayish pubescent. Leaves elliptic to obovate or oblong-obovate, 3 to $9 \mathrm{~cm}$. long and 1.5 to $3.5 \mathrm{~cm}$. broad, acute or obtusish and gland-tipped at apex, cuneate at base, setosely ciliate, finely pubescent on both sides, more densely beneath, particularly on the veins, rarely glabrescent above at maturity; petioles 3 to $8 \mathrm{~mm}$. long, pubescent and glandular and usually sparingly strigose. Flowers appearing shortly before or with the leaves, end of March or in April in 8- to 15-flowered umbel-like racemes; pedicels 0.5 to $1 \mathrm{~cm}$. long, pubescent and glandular-setose; sepals broadly ovate to oblong, unequal, 1 to $2.5 \mathrm{~mm}$. long, glandular-ciliate, pubescent outside; corolla yellow and orange, the tube usually more or less purplish or with 5 longitudinal purplish stripes, slightly fragrant, the tube cylindric, abruptly dilated at the apex, 1.5 to $2 \mathrm{~cm}$. long, finely pubescent and stipitate-glandular, the lobes ovate 1 to $1.5 \mathrm{~cm}$. long and 0.6 to $1 \mathrm{~cm}$. broad, short-acuminate with recurved point, finely pubescent outside; stamens nearly three times as long as tube, the filaments pubescent below the middle, the anthers ochraceous, 2 to $3 \mathrm{~mm}$. long; style slightly exceeding the stamens, 5 to $6 \mathrm{~cm}$. long, short-pilose near the base; ovary covered with long whitish strigose, partly gland-tipped hairs. Capsule oblong-cylindric, slightly narrowed toward the apex, 1.5 to $2.5 \mathrm{~cm}$. long, covered with a thin fine pubescence interspersed with long strigose partly gland-tipped hairs.

This species has a very restricted distribution; it has been found only in Gadsden County, in northern Florida, near River Junction and Chattahoochee, close to the Georgia state line and about ten miles farther south at Aspalaga near Rock Bluff, Liberty County (Biltmore Herb. 6088). It was apparently first discovered by Dr. Chapman some time before 1865, as he refers to it in his Flora under $R$. nudiflorum as a color variation of that species; there is also a specimen collected by him in the National Herbarium without date and locality with the note "flowers orange." The species was again collected in 1880 by A. W. Curtiss and distributed as $R$. nudiflorum var. luteum, but that name was never published and this Azalea was not recognized as distinct until described as a species by Dr. Small in 1913.

$R$ hododendron austrinum is so closely related to $R$. canescens that one might be induced to consider it only a color form of that species, but aside from the fact that the yellow color is a disconnected deviation from the pink color tones of $\boldsymbol{R}$. canescens, $R$. austrinum differs further in the glandular ovary and capsule, entirely destitute of glands in $R$. canescens, and in the copious glandular pubescence of the calyx and pedicels which are usually, though not always, glandless in $R$. canescens. In their general appearance, however, I could see no difference except the color between the two species, when I saw them growing side by side in Mr. H. H. Hume's garden in Jacksonville, who had brought the plants of both species from River Junction the year before.

The species was first introduced into cultivation through the Arnold Arboretum, where plants were raised from seed collected in 1914 by Mr. T. G. Harbison near River Junction. It cannot be expected to thrive in northern gardens, but for southern gardens it may be desirable on account of its yellow flowers.

Rhododendron atlanticum Rehder, comb. nov.

Azalea nudiflora M. A. Curtis in Boston Jour. Nat. Hist. I. 100 (Enum. Pl. Wilmington) (1834), not Linnaeus. ${ }^{1}$ - Croom, Cat. Pl. Newbern, 21 (1837).- Wood \& McCarthy, Wilmington Fl. 34 (1886).

1 I have seen in the herbarium of the Academy of Natural Science at Philadelphia a specimen collected by Curtis at Wilmington and named by him $A$. nudifora, which proves to be $R$. atlanticum. The true $R$. nudiflorum has not been found near Wilmington. 
Azalea atlantica Ashe in Bull. Charleston Mus. XIII. 26 (1917). - Coker in Jour. Elisha Mitchell Soc. XXXVI. 97, pl. 1, 7 (1920).

Low stoloniferous shrub rarely more than $0.5 \mathrm{~m}$. tall, with slender upright usually sparingly branched or simple stems; young branchlets sparingly strigillose and sometimes glandular hirsute, otherwise glabrous, occasionally slightly glaucescent, reddish brown at the end of the season, becoming grayish brown and glabrous the second year; floral winter-buds with ovate, mucronulate, light brown and white-ciliolate, glabrous or slightly silky-pubescent scales. Leaves obovate to oblong-obovate, rarely elliptic, rounded or acutish and gland-tipped at apex, cuneate at base, 3 to $6 \mathrm{~cm}$. long and 1.5 to $2 \mathrm{~cm}$. broad, setosely ciliate or minutely serrulate-ciliate, glabrous above except the villose midrib and bright green or bluish green, glabrous and sparingly strigillose and sometimes pubescent on the midrib beneath, rarely strigillose on the surface, and glaucescent or bright green, chartaceous at maturity, the secondary veins scarcely prominent beneath and the veinlets obscure; petioles 1 to $5 \mathrm{~mm}$. long, sparingly strigillose. Flowers appearing before or with the leaves in April or beginning of May in clusters of 4 to 10; pedicels about $1 \mathrm{~cm}$. long, hirsute or glandular-hirsute, otherwise glabrous, rarely minutely and slightly villose; sepals broadly ovate, small or occessionally oblong and 2 to $4 \mathrm{~mm}$. long, glandular-ciliate or sometimes eglandular; corolla funnel-form, white, usually flushed pink or purple outside, very fragrant, the tube cylindric, rather gradually dilated at apex, 2 to $2.5 \mathrm{~cm}$. or rarely to nearly $3 \mathrm{~cm}$. long, outside with numerous short gland-tipped hairs, otherwise glabrous or only slightly villose, glabrous or nearly so inside, the lobes ovate to ovate-oblong, acute, 1.3 to $2 \mathrm{~cm}$. long, stipitate-glandular along the middle; stamens exserted, about twice as long as the tube, the filaments hairy below the middle, the anthers 2 to $3 \mathrm{~mm}$. long; style exceeding the stamens, 4.5 to $5.5 \mathrm{~cm}$. long, pubescent below the middle, usually purplish above; ovary with setose, gland-tipped or glandless hairs. Capsule ovoid-oblong, 1.5 to $2 \mathrm{~cm}$. long, setose, the setae glandless or gland-tipped.

Delaware. Kent County: Choptank Mills, May 29-30, 1904, Witmer Stone (Herb. Acad. Nat. Sci. Phila.).

District of Columbia. Washington, Takoma Park, May 11, 1900, T. A. Williams.

Virginla. Princess Anne County: May 9, 1898, Th. $H$. Kearney (No.1062; Nat.Herb. No.355,802). Nansemond County: near Suffolk, April 30, 1898, Fr. Coville \& Th. H. Kearney (No.49; Nat. Herb. No. 355,681).

North Carolina. Johnston County: Selma, April 23, 1918, and November 19, 1919, T. G. Harbison (Nos. 1-8, 10). Craven County: Newbern, April 7 and 18, 1918, April 20 and Nov. 20, 1919, T. G. Harbison (Nos. 7, 14, 17, 23, 30, 101, 102, 115, 116, 117, 121, 131, 132). New Hanover County: Wilmington, April 2, 1880, C. S. Sargent; April 14 and 15, 1911, C. S. Williamson; April 18 and 19, 1919, T. G. Harbison (Nos. 36-41, 47, 48), without date, M. A. Curtis. Eastern N. Carolina, without precise locality, April, 1888, G. McCarthy (Nat. Herb. 42,633).

South Carouina. FlorenceCounty : Ebenezer, wet Pine barren, 
Sept. 26, 1911, H. H. Bartlett (No. 2857; Nat. Herb. No. 586,340); three miles east of Florence, April 17, 1897, L.F. Ward (Nat. Herb. No. 284,925); Georgetown County: Georgetown (type locality), April 25, 1918, T. G. Harbison (Nos. 11, 14).

This species is restricted to the coastal plain region from Delaware to South Carolina. It is characteristic of the low pine lands, where it forms extensive colonies almost to the exclusion of the other shrubs and often occupies large stretches; the low stoloniferous shrubs, rarely more than half a meter high, dotted over the grassy forest floor, form in spring with their white or pinkish very fragrant flowers a conspicuous feature of these woods. I noticed it from the railroad train from northern South Carolina to Virginia for a distance of more than 150 miles almost everywhere in the pine woods and often spreading into the adjacent fields.

Rhododendron atlanticum seems to be most closely related to $R$. viscosum, with which it agrees perfectly in its leaves, in the shape of the corolla with its slender cylindrical tube, glabrous inside and glandular-hirsute outside, in the strong fragrance of its flowers and in the densely setose but scarcely villose capsule, but usually it can be easily distinguished by its low stoloniferous habit, its early appearing flowers, the usually nearly glabrous branchlets and the absence of the fine pubescence on the outside of the corolla and the less abrupt expansion of its tube into the limb. There are, however, particularly in the coastal plain region from Maryland to South Carolina, forms of $R$. viscosum of low and somewhat stoloniferous habit (see page 159) which might be confused with $R$. atlanticum and in the south $R$. viscosum begins to flower often about or sometimes before the middle of May, but the flowers of that species always appear after the leaves are nearly fully developed and the fine villose pubescence of the outside of the corolla, absent or nearly absent in $R$. atlanticum, and the generally slenderer corolla more abruptly dilated at the apex afford characters to separate the two species. Rhododendron atlanticum has been also confused with $R$. nudiforum, but from that species it is readily distinguished by the low stoloniferous habit, by the smaller obovate leaves chartaceous at maturity, the very fragrant flowers, the much longer tube of the corolla glandular-hirsute outside and lacking the fine villose pubescence of the corolla of $R$. nudiflorum, by the glabrous inner surface of the corolla-tube and the conspicuous rows of stipitate glands at the apex of the flower-bud.

Rhododendron atlanticum has always been confused with the two species just mentioned until Ashe described it in 1917 as a new species. The oldest specimens I have seen are those collected as Azalea nudifora by M. A. Curtis, one on Society Hill, South Carolina, representing at least partly the variety luteo-album, and one collected near Wilmington, North Carolina, probably in the early thirties while he was residing at Wilmington. The species is in cultivation at the Arnold Arboretum, where a plant was received in 1920 from Mr. Ashe who had grown it in his garden at Washington for several years; it is doubtful, however, if this species proves hardy in the northern states.

\section{Rhododendron atlanticum f. neglectum Rehder, comb. nov.}

\section{Azalea neglecta Ashe in Bull. Torr. Bot. Club, XLVII. 581 (1920).}

This form, based by Ashe on specimens collected by him near Georgetown, South Carolina, May, 1916, is hardly specifically distinct from $R$. atlanticum; it differs chiefly in the purplish pink color of its flowers, the somewhat shorter and wider tube and the usually more villose pubescence of the corolla. Specimens of his new species collected near Kinlock, South Carolina, on May 1, 1920, kindly sent 
by $\mathrm{Mr}$. Ashe, show well the purplish pink color of the flowers; the corolla tube is slightly shorter and wider than in the typical $R$. atlanticum and is furnished outside with numerous gland-tipped stiff hairs, which are more numerous in one of the specimens sent and less numerous in the other, but in the latter the tube is also thinly covered with a fine villose pubescence, which in typical $R$. atlanticum is absent or nearly absent, though occasionally, as in Harbison's No. 14 from Georgetown, South Carolina, the type locality of the species, and in his Nos. 38 and 41 from Wilmington, North Carolina, this villose pubescence is present. To f. neglectum I also refer Harbison's No. 14 from Newbern, North Carolina, collected April 17, 1918, though this differs in its narrow-oblong calyx-lobes, up to $5 \mathrm{~mm}$. long, and possibly also his Nos. 7, 101, 102 from the same locality, Nos. 37, 40 and 47 from Wilmington, and his Nos. 3 and 5 from Selma, North Carolina, may belong to this form, if we consider the color its chief distinguishing character.

Rhododendron atlanticum var. luteo-album Rehder, comb. nov.

Azalea atlantica var. luteo-alba Coker in Jour. Elisha Mitchell Sci. Soc. XXXVI. 98, pl. 1, fig. (at right) (1920).

This variety differs from the type in the dull bluish green leaves finely pubescent on both surfaces and strigillose above, in the finely villose petioles and in the stipitate glandular young branchlets; the flowers white, when open, are sometimes yellowish in bud without any trace of pink.

Sodth Carolina. Darlington County : Ditch bank southeast of Hartsville plantation of J. L. Coker \& Co., spring of 1918, J. L. Coker, $J r$. (co-type); flat woods south of Hartsville plantation, April 29, 1915, W. C. Coker; without precise locality, in sandy soil (No. 8), in sandy soil near roadside (No. 14), in cultivated field (No. 13), April 24, 1918, T. G. Harbison; in low sandy pine woods, November 22, 1919, T. G. Harbison (Nos. 31, 32); Society Hill, no date, M. A. Curtis (Gray Herb., partly typical $R$. atlanticum).

This variety was based originally on the color of the flowers, but as a specimen kindly sent me by the author of the variety shows, it is at the same time rather densely pubescent and differs in this respect from the type of the species. As the pubescence seems to me the more important character, I prefer to include in this variety all the specimens with pubescent leaves without regard to the difference in the color of the flowers, which, moreover, seems to be not very pronounced, for I can hardly see any difference between the two forms as represented on the colored plate cited above.

Rhododendron oblongifolium Millais, Rhodod. 219 (1917). - Millais \& Williams in Rhodod. Soc. Notes, I. 125 (1918).

Azalea oblongifolia Small, Fl.S. E. U.S. 883, 1336 (1903); in N. Am. Fl. XXIX. 43 (1914).

Shrub to $2 \mathrm{~m}$. high or less, with irregularly whorled branches; young branchlets with short and rather sparse villose pubescence and usually with sparse strigose hairs or sometimes nearly glabrous; floral winter-buds with ovate, acuminulate or obtuse, grayish pubescent scales. Leaves obovate or elliptic-obovate to oblongoblanceolate, rarely oblong, 4 to $10 \mathrm{~cm}$. long and 1.5 to $3.8 \mathrm{~cm}$. brosd, acutish or acute, gland-tipped, cuneate, ciliate, dull green and glabrous above except the vil- 
lose midrib or sometimes strigillose and minutely pubescent, light green, or rarely glaucescent beneath, pilose and strigillose on the midrib, more or less pubescent on the whole under surface or nearly glabrous; petioles 2 to $3 \mathrm{~mm}$. long, finely pubescent. Flowers expanding at the middle or end of May or in southeastern Texas at the end of April, after the leaves are fully formed, and borne in 7-to 12-flowered clusters; pedicels 1.5 to $2 \mathrm{~cm}$. Iong, sparingly villose and glandular-hirsute; calyx-lobes unequal, ovate to oblong or lanceolate, obtuse to acute, 1 to $3 \mathrm{~mm}$. long, longciliate and sparingly villose outside; corolla funnel-form, white, the tube cylindric, abruptly dilated at the apex, 2.5 to $3 \mathrm{~cm}$. long, thinly villose and sparingly glandular-hirsute outside or more densely villose and destitute of stipitate glands except on the outside of the lobes, sparingly pubescent above the middle or glabrous inside, the lobes oblong-ovate, acute, 1.8 to $2 \mathrm{~cm}$. long, glandular-hairy along the middle outside; stamens about twice as long as the tube, slightly exceeding the corollalobes, villose below the middle, the anthers ochraceous, 2.5 to $3 \mathrm{~mm}$. long; style exceeding the stamens, 5 to $6 \mathrm{~cm}$. long, finely pubescent at the lower third, or sometimes glabrous; ovary usually not or little longer than the sepals, covered with upright setose hairs partly glandular. Capsule oblong or ovoid-oblong to narrowoblong 1.2 to $1.8 \mathrm{~cm}$. long, finely villose and glandular-setose.

Arkansas. Newton County: rocky woods, Jasper, October 28, 1914, E. J. Palmer (No. 6932). Cleburne County: sandy woods, Heber Springs, October 31, 1914, E. J. Palmer (No. 6973); Pulaski County: Little Rock, H. E. Hasse. Pike County: Delight, May 20, 1910, A. H. Howell (No. 659; Nat. Herb. No. 514,206). Hempstead County: Fulton, sandy woods, May 21 and Oct. 5, 1909, B. F. Bush (Nos. 5684, 5955); Washington, moist sandy woods, Sept. 4, 1916, E. J. Palmer (No. 10,583); Columbus, along sandy streams, - July 17, 1916, E. J. Palmer (No. 10,505). Ouachita County : Camden, 1850, A. Fendler. Miller County: Doddridge, moist sandy woods, July 19, 1916, E. J. Palmer (No. 10,515). "National Forest," 1907 (Nat. Herb. No. 615,731).

OrLahoma. Leflore County: near Page, near mountain creek, April 20 and September 7, 1913, G.W. Stevens (Nos. 1390, 2658), on low creek branch, June 20,1914, D.W. Blakeley (G. W. Stevens, No. 1418; Nat. Herb. No. 589,543); rocky woods, valleys in limestone and lower levels of sandstone hills, July $27,1917, E$. J. Palmer (No.12,644). McCurtain County : Idabel, May 29, 1916, H.W. Houghton (G. W. Stevens, No. 3925).

Texas. Harrison County: Marshall, common in swamp, Oct. 5, 1901, B. F. Bush (No. 983). San Augustine County: San Augustine, margin of sandy swamps, September 10, 1917, E. J. Palmer (No. 12,710). Houston County: Grapeland, 1879, Frank Tweedy ${ }^{1}$;

- This is the type specimen collected at "Grapelands," as stated in a letter by F. Tweedy accompanying the specimen and dated March 15, 1899. On the label, which is not in Mr. Tweedy's handwriting, however, Tom Green County is given as the locality, which is apparently a mistake, for there are no Rhododendrons 
sandy bogs, May 28, 1917, September 22 and 28, 1917 (Nos. 12,830, 12,831), March 26 and April 2, 1918, E. J. Palmer (Nos. 13,181, 13,265). Hardin County: Silsbee, sandy pine lands, April 25 and September 10, 1916, E.J. Palmer (No. 9568; shrub 4-6 cm. high, flowers pure white, No. 10,689). Without definite locality and date; C. Wright (in Gray Herb.).

This is the most western species of the eastern group of Rhododendrons and in distributed from northern Arkansas (Newton and Cleburne Counties) to southeastern Oklahoma and through southeastern Arkansas to southeastern Texas (Houston and Hardin Counties). It is a low shrub growing in moist sandy woods or on the margins of sandy bogs and along streams.

Rhododendron oblongifolium is most nearly related to R. viscosum and $R$. semulatum, but differs chiefly in the finely villose, sparingly strigose branchlets, the pubescent winter-buds, in the larger leaves of thinner texture and usually more or less pubescent, in the larger corolla finely villose and glandular outside and in the usually longer calyx-lobes; the flowers appear earlier, in May or even at the end of April, while $\boldsymbol{R}$. serrulatum flowers in July and August and $\boldsymbol{R}$. viscosum from the end of May to the beginning of July. Without flowers the pubescent forms of it have some resemblance to $R$. canescens and have been sometimes confused with that species. It shows considerable variability in some characters, particularly in the pubescence of the leaves, which may be glabrous or more or less pubescent beneath; the extreme forms look very distinct but they are closely connected by numerous intermediates and both forms frequently occur at the same locality and have been distributed by the collectors even under the same number as Bush's No. $5955^{1}$ from Fulton, Arkansas, and Palmer's No. 12,644 from Page, Oklahoma. The upper surface of the leaves also varies from being quite glabrous, except the pubescent midrib, to strigillose and with or without a minute villose pubescence. Sometimes the under side of the leaves is more or less covered with a glaucous bloom, as in part of Palmer's No. 12,644 from Oklahoma and in his 12,062 and part of 12,830 from Texas. The young branchlets may be puberulous all over and sparingly strigose toward the apex or nearly glabrous; the winter-buds are always densely pubescent. The calyx-lobes are sometimes very short and semi-orbicular or ovate, as in Palmer's Nos. 9568, 12,062 and 12,063 from Texas and in his No. 10,583 from Arkansas. The outside of the corolla is usually covered with a thin villose pubescence interspersed with numerous stipitate glands but sometimes, as in Palmer's Nos. 9568 and 12,063, the tube is more densely villose and destitute of glands, which are present only toward the apex of the corolla on the outside of the lobes; in the same numbers the style and the inside of the tube are glabrous. These characters together with the rather dense villose pubescence of the under side of the leaves of No.12,063 might induce one to make this number the type of a distinct variety, but considering the great variability of the species even in the same locality and the apparent absence of any correlation of the different forms with their geographical distribution, I think it wiser to defer a subdivision of the species into varieties or forms until a careful field study has been made and more copious material is available.

known growing as far west as Tom Green County, Houston County marking the farthest western limit of the genus in the Eastern States.

1 The glabrous form of this number looks very distinct, the leaves are broad and generally obovate, quite glabrous except sparingly strigillose on the midrib beneath, even the branchlets are quite glabrous and the specimen, which is in fruit, might be taken for $R$. arborescens but for the pubescent winter-buds. 
Some of the specimens enumerated above are rather poor and do not show clearly he distinguishing characters of the species and might be taken for forms of $R$. viscosum, but they have been placed here chiefly for geographical reasons, since we have no knowledge that $R$. viscosum extends farther west than eastern Tennessee. The species was apparently first collected by A. Fendler near Camden, Arkansas, in 1850 and about the same time by C. Wright in Texas. Later it was found by Frank Tweedy at Grapeland, Houston County, Texas, and upon his specimen Dr. Small based his Azalea oblongifolia published in 1903. It was introduced into cultivation through the Arnold Arboretum, where plants were raised from seeds collected in 1917 by E. J. Palmer near Washington, Arkansas.

Rhododendron serrulatum Millais, Rhodod. 241 (1917). - Millais \& Williams in Rhodod. Soc. Notes, I. 125 (1918).

Azalea viscosa Hooker in Comp. Bot. Mag. I. 100 (1835), ${ }^{1}$ not Linnaeus. Mohr, Pl. Life Ala. 653 (1901), in part. - Small, Fl.S. E. U. S. 883 (1903), in part; Shrubs Fla. 94 (1913); in N. Am. Fl. XXIX. 42 (1914), in part.

Rhododendron viscosum Chapman, Fl. S. U.S. 265 (1865), not Torrey.

Azalea serrulata Small, Fl. S. E. U. S. 883 (1903); in N. Am. Fl. XXIX. 43 (1914).

Shrub to $7 \mathrm{~m}$. tall, with irregularly whorled branches; young branchlets usually cously strigose toward the apex and finely villose or nearly glabrous, becoming soon bright red-brown, changing to dull brown or grayish the following year; floral winter-buds glabrous or sometimes grayish pubescent with numerous usually 15 to 20 ovate scales mucronate or mucronate-aristate, usually light yellowish brown with a sharply marked dark brown band along the white-ciliolate margin. Leaves elliptic to obovate or obovate-oblong, rarely oblanceolate, 4 to $8 \mathrm{~cm}$. long and 1.5 to $3.8 \mathrm{~cm}$. broad, on vigorous shoots often oblanceolate and 8 by $2 \mathrm{~cm}$. large, usually acute, rarely obtuse, gland-tipped, cuneate at the base, serrulate-ciliate on the margins, glabrous above except sparingly short-villose on the midrib, glabrous beneath and strigose on the midrib, or on the upper leaves of shoots soft-pubescent beneath and strigillose and more or less puberulous above, firm at maturity; petioles 1 to $4 \mathrm{~mm}$. long, strigose. Flowers appearing after the leaves and after the winter-buds are at least partly formed from the middle of June to the beginning of August, in 6- to 10-flowered umbel-like racemes; pedicels slender, 1 to $2 \mathrm{~cm}$. long, glandular-hirsute and sparingly villose; calyx-lobes semiorbicular to ovate, rarely exceeding $1 \mathrm{~mm}$., ciliate with long glandular hairs; corolla white, funnel-form, very fragrant, the tube cylindric, slender, 2.5 to $3.3 \mathrm{~cm}$. long and about $2 \mathrm{~mm}$. wide, slightly dilated at apex, rather copiously glandular-pilose and sparingly villose outside, glabrous inside, the lobes ovate-lanceolate, acuminate, 1.2 to $1.5 \mathrm{~cm}$. long; stamens exserted, about $11 / 2$ times as long as tube, exceeding the lobes, glabrous in the upper third, villose below; anthers oblong, 2 to $2.5 \mathrm{~mm}$. long, ochraceous; style considerably exceeding the stamens, 4.5 to $5.8 \mathrm{~cm}$. long, slightly short-pubescent near the base or nearly glabrous, purple above; ovary densely covered with gland-tipped setae. Capsule ovoid-oblong, 1 to $1.3 \mathrm{~cm}$. Iong, minutely villose and densely glandular-setose.

Georgia. Wayne County: Jessup, October, 1916, T. G. Harbison (No. 240). Charlton County: near Folkston, April 3 (No. 10),

${ }^{1}$ Drummond's No. 190 named A. viscosa by Hooker is represented in the Gray Herbarium by a sheet consisting of two specimens, one with mature leaves, which is $R$. serrulatum, and one in flower, which is $R$. canescens. Hooker quotes this number as 198, but No. 198 belongs to Vaccinium dumosum (Gaylussacia dumosa). 
July $15-17$ (Nos. $62,63,64,65,67,70,81,82,84,87$ ) and December 15 , 1918 (No. 93), June 16 and 18 (Nos. 97, 99) and November 26 and 27, 1919 (Nos. 100, 102, 103, 110, 111, 112, 114, 115), T. G. Harbison; without locality, May 17, 1918, T. G. Harbison (Nos. 29, 33, 34, 46, 57). Lowndes County: Ousley, October 21, 1910, T. G. Harbison (Nos. 242, 246, 251); near Valdosta, June 6-12, 1895, J. K. Small. Brooks County: Quitman, April 2, 1918, T. G. Harbison (No. 5).

Florma. Lake County: Eustis, June 1-15, 1894, G. V. Nash (No. 967, type); June 16-31, G. V. Nash (No. 1306); same locality, December 12, 1919, T. G. Harbison (Nos. 21, in part, 26, 27). Seminole County: near Wekiva Springs, May 9, 1918, C. H. Baker (No. 499 a-c). Orange County: near Maitland, February 27 (Nos. 478 a-b), June 20 (No. 529 a) and July 12, 1918, C. H. Baker (Nos. 529 b, 478 c, d, f); swamps, July 10, 1902, A. Fredholm (No. 5379; in Gray Herb.). Polk County: Lakeland, August 1, 1918, T. G. Harbison. De Soto County: Sebring, July 28, 30, 1918, T. G. Harbison (Nos. 19, 20, 21, 47). Escambia County: Pensacola, April 18, 1899, Biltmore Herb. (Nat. Herb. No. 969,619). Calhoun County: Apalachicola, T. Drummond (in Gray Herb.). Without precise locality: 1842-49, F. Rugel (No. 237; Nat. Herb. 512,161); without date, Herb. Chapman (Nat. Herb. No. 955,093).

Alabama. Mobile County: near Mobile, July, 1887, C. Mohr; same locality, December 4, 1919, T. G. Harbison (Nos. 1, 2); Spring Hill, August 6, 1897, B.F. Bush (No. 12); same locality, December 4, 1919, T. G. Harbison (Nos. 1-4).

MississipPi. Jackson County: Ocean Springs, June 19, 1895, J. Skehan. Harrison County: Biloxi, July 29, 1896, C. L. Pollard (No. 1097; Nat. Herb. 271,755); August 21, 1898, S. M. Tracy (No. 4395; Nat. Herb. 770,586); October 30, 1917, T. G. Harbison (No.6), April 1 (No. 1), May 6 (Nos. 2, 3, 24) and July 19, 1918, T. G. Harbison (No. 25-33).

Louisiana. St. Tammany Parish: Pearl River, July 9, 1909, R. S. Cocks (No. 2222); New Orleans (Covington), 1832, T. Drummond (No. 190). ${ }^{1}$

This Azalea is distinctly a species of the southern coastal plain region and extends from southern Georgia or, including the variety georgianum, from middle Georgia to central Florida (De Soto County) and westward along the coast to southeastern Louisiana. Its type locality is Eustis, Lake County, Florida. It inhabits swamps or moist sandy soil and is usually a tall shrub 2 to $7 \mathrm{~m}$. high.

Rhododendron serrulatum is closely related to R. viscosum and takes its place south

${ }^{1}$ See footnote on page 153. 
of central Georgia. It is chiefly distinguished by the brown-red branchlets usually conspicuously and densely covered toward the ends with strigose red-brown hairs, by the aristate or at least distinctly mucronate more numerous scales of the winterbuds, usually glabrous and with a conspicuous dark band along the margin, by the long and slender corolla-tube about twice as long as the comparatively small lobes, and by the stamens considerably exceeding the lobes; the leaves are of firmer texture and more distinctly serrulate on the margin and are not unfrequently, particularly those toward the end of vigorous shoots, more or less densely pubescent on the under side; it is usually a tall shrub, while $R$. viscosum, partieularly in the southern part of its range, is usually a low, sometimes even stoloniferous shrub. Small in his description and keys lays much stress on the oval shape of the leaves, but though the type specimen which has only short and weak branchlets and no vigorous shoots happens to have most of its leaves of elliptic shape, this is the more unusual shape, while the prevailing shape of the leaves varies from obovate to oblong-obovate or sometimes oblanceolate. Until Small described it as a new species, $R$. serrulatum had been always confused with $R$. viscosum and even he understood under that name only the uncommon form with oval or elliptic leaves and referred the forms with obovate leaves to $R$. viscosum, making it a very local species, while really it has a rather wide distribution. Like the other related species it varies in the pubescence of its leaves, which may be glabrous except strigose hairs on the midrib beneath, as in the type, or more or less, sometimes densely pubescent on their under side and strigillose and puberulous above; the pubescence may appear either on all the leaves or chiefly on upper leaves of the more vigorous shoots, while the leaves appearing earlier in the season are glabrous or nearly glabrous. The form with the leaves always pubescent is described below as a distinct form. Sometimes the leaves of the glabrous form are glaucescent beneath, as in some specimens from Folkston, Georgia. Also the winter-buds vary in their pubescence; typically they are perfectly glabrous, but sometimes they are more or less densely pubescent and these specimens I have referred to a distinct variety, described below. In the shape of the corolla, in its pubescence and in its color, which is apparently always white or nearly white, I find little variation except that the tube varies somewhat in length.

This species was apparently first collected by T. Drummond about 1830 near New Orleans in Louisiana and near Appalachicola in Florida; it also was collected in Florida by T. Rugel in the forties and by Chapman in the fifties or sixties, but it was not distinguished until Dr. Small in 1903 described his Azalea serrulata, based on a specimen collected by G. V. Nash near Eustis, Florida, which had most of the leaves of distinctly oval or elliptic shape. The shape of the leaves, however, cannot be considered a reliable character, as already stated.

Rhododendron serrulatum was introduced into cultivation through the Arnold Arboretum, where plants were raised in 1919 from seeds collected by T. G. Harbison in December, 1918, near Folkston, Georgia. It will probably not be hardy north and as an ornamental shrub it will not be superior to $R$. viscosum, but for southern gardens it may be valuable on account of its late appearing fragrant flowers.

Rhododendron serrulatum $f$. molliculum Rehder, forma nova.

A typo recedit ramulis annotinis apicem versus densius villosulis $\mathbf{v}$. glabrius culis minus strigosis, foliis subtus molliter subaccumbenti-villosis supra sparsius villosulis et saepe praecipue in foliis superioribus strigillosis, pedicellis magis villosulis.

Florida. Lake County: Eustis, June 23, 1919, T. G. Harbison (No. 17, type, 19, 20, 21, partly); December 12, 1919 (No. 25); June 16-30, 1894, G. V. Nash (No. 1104; Nat. Herb. 223,237). 
Georgia. Charlton County: Folkston, June 16 and July 16, 1918, T. G. Harbison (No. 69, 98); without precise locality, May 18, 1918, T. G. Harbison (No. 58).

This form differs from the type in all the leaves being densely soft-pubescent beneath and slightly puberulous and often strigillose above; also the branchlets are usually more or less puberulous and the pedicels are more densely villose, while the winter-buds are glabrous as in the type. Pubescent leaves are also found occasionally in the typical form, but they are restrieted to the upper part of the more vigorous branchlets, while the leaves of the short branchlets which are usually terminated by floral winter-buds and the lower leaves on the shoots are glabrous or nearly so. Such pubescent leaves are present, e. g. in Chapman's specimen, in Harbison's No. 6 from Lakeland, Florida, in his Nos. 21 (partly) and 27 from Eustis, in Nash's No. 1306 from the same locality, in Baker's No. 529 a from Maitland and in his No. 499 a from Wekiva Springs, in Harbison's No, 20 from Sebring, Florida, in his No. 84 and 100 from Folkston, Small's specimen from Valdosta, Harbison's No. 2 from Mobile, Alabama, and his Nos. 24, 27, 28 from Biloxi, Mississippi, and Cock's No. 2222 from Pearl River, Louisians.

\section{Rhododendron serrulatum var. georgianum Rehder, var. nov.}

A typo recedit gemmis dense sericeo-pubescentibus perulis paucioribus et tantum mucronatis vix aristatis.

Georgia. Charlton County: Folkston, July 16, 1918, T. G. Harbison (No. 68, type; shrub $10 \mathrm{ft}$. tall; No. 77), July 15 (No. 66), July 17, 1918 (No. 86, shrub $18 \mathrm{ft}$. tall) and Nov. 27, 1919, T. G. Harbison (No. 118, low shrub); without precise locality May 17 and 18, 1918, T. G. Harbison (Nos. 34 and 57; tall late-blooming species). Richmond County: Augusta, sand hills, swamp, July, 1904, A. Cuthbert. Bryan County : boggy places in sand hills of Canoochee River near Groveland, June 22, 1903, R. M. Harper (No. 1850). Screven County : near Oliver, July 9, 1901, A. H. Curtiss (No. 6837; 8 to 12 feet high). Appling County: swamps near Baxley, August 10, 1901, Biltmore Herb. No. 4823 (Nat. Herb. 980,173). Lowndes County: Ousley, October 21, 1910, T. G. Harbison (Nos. 244, 248). Randolph County: Cuthbert, December 1, 1919, T. G. Harbison (Nos. 31,32 ; low shrub). Decatur County: moist pine barrens near Climax, August 13, 1903, R. M. Harper (No. 1929).

South Carolina. Beaufort County: Bluffiton, 1893, J. H. Mellichamp.

This variety differs from the type only in the densely grayish pubescent winterbuds with usually less numerous and only mucronate, not aristate scales from the type. It approaches thus in its winter-buds $R$. viscosum and may be considered an intermediate form not only on account of its characters but also in regard to its distribution, occupying as it does an area between $R$. viscosum and typical $R$. serrulatum. I have not yet seen any specimens of this variety from Florida or from localities west of Georgia, while typical $R$. serrulatum does not seem to extend farther 
north than Wayne County; from Lowndes and Charlton Counties I have seen both, the type and this variety. The fact that this form occupies a fairly well-defined range chiefly induced me to consider it a distinct variety though differing only in the minor character of the pubescent winter-buds. Except in the amount of pubescence of the winter-buds it shows little or no variation. Harper's No. 1929 from Climax is the only specimen of this variety which shows part of the leaves pubescent; it differs also in its small nearly ovoid capsules less than $1 \mathrm{~cm}$. long. Whether Mallichamp's specimen from South Carolina really belongs here or is perhaps a form of $R$. viscosum I am not quite sure.

Rhododendron viscosum Torrey, Fl. U. S. 424 (1824); Fl. N. Y. I. 439, t. 66 (1843). - G. Don, Gen. Syst. III. 847 (1834). - Loudon, Arb. Brit. IV. 1143, fig. 947 (1838). - Gray, Syn. Fl. II. 1, 40 (1878). - J. Robinson, Fl. Essex Co. Mass. 73 (1880). - Owen, Pl. Nantucket, 39 (1888). - Dame \& Collins, Fl. Middlesex Co. Mass. 62 (1888). - Bennett, Pl. Rhode Isl. 26 (1888). - Dippel, Handb. Laubholzk. I. 416, fig. 269 (1889). - Britton, Cat. Pl. N. Jersey, 162 (1889). - Coulter \& Watson, Gray's Man. ed. 6, 320 (1890). - Deane, Fl.Metrop. Park, Mass. 53 (1896); in Rhodora, I. 94 (1899). - Robinson \& Fernald, Gray's New Man. ed. 7, 631 (1908). - J. Jackson, Cat. Pl. Worcester Co. Mass. 75 (1909). - Graves \& others, Cat. Fl. Pl. Conn. 308 (1910). - Schneider, Ill. Handb. Laubholzk. II. 502, fig. 329 n-p, $330 \mathrm{c}-\mathrm{d}$ (1911). - Stone, List Pl. Franklin, Hampshire and Hampden Cos. Mass. 48 (1913). - Twining, Fl. N. E. Pennsylv. 56 (1917). Millais, Rhodod. 259 (1917).

Azalea viscosa Linnaeus, Spec. I. 151 (1753). - Wangenheim, Beytr. Forstwiss. 66, t. 25, fig. 52 (1787). - Willdenow, Spec. I. pt. 2, 831 (1798). Michaux, Fl. Bor.-Am. 150 (1803). - Pursh, Fl. Am. Sept. 153 (1814). Eaton, Man. Bot. 25 (1817). - Bigelow, Fl. Boston, 52 (1814). - Barton, Fl. Phila. 113 (1818). - Elliott, sketch Bot. S. C. I. 241 (1821). - M. A. Curtis, Enum. Pl. Wilmington, 100 (1834).-Croom, Cat. Pl. Nevo Bern, 21 (1837). - De Candolle, Prodr. VII. 715 (1839). — Gray, Man. 268 (1848); ed. 5, 299 (1872). - Tracy, Stud. Essex Fl. 50 (1858). - M. A. Curtis, Descript. Trees \& Shrubs, 98 (in Geol. Nat. Hist. Surv. N. Car. III. Bot.) (1860). Willis, Cat. Pl. N. Jersey, 33 (1874). - Wood \& McCarthy, Wilmington Fl. 34 (1886). - Britton \& Brown, Ill. Fl. II. 559, fig. 2747 (1897). Jelliffe, Fl. Long Island, 124 (1899). - Britton, Man. 698 (1901). - Gattinger, Fl. Tenn. 131 (1901). - Porter, Fl. Pennsylv. 238 (1903). - Small, Fl.S.E.U.S. 883 (1903), in part; in N.Am.Fl. XXIX. 42 (1914), in part. Shreve \& others, Pl. Life Maryland, 466 (1910). - W. Stone in Ann. Rep. N. J. State Mus. 1910, 613, t. 58, fig. 2 (1911). - Millspaugh, Liv. Fl. W. Virginia, 323 (in W. Va. Geol. Surv.) (1913). - Taylor, Fl. Vicin. N. Y. 489 (Mem. N. Y. Bot. Gard. V.) (1915).

Azalea viscosa palustris Marshall, Arbust. Am. 16 (1785).

Rhododendron venustum Salisbury, Prodr. 287 (1796), in part.

Azalea virens Dumont de Courset, Bot. Cult. ed. 2, III. 335 (1811), as var. of A. viscosa.

Azalea nitida Lindley in Bot. Reg. V. t. 435 (1819), not Pursh. 
Anthodendron viscosum Reichenbach in Moessler, Handb. Gewächsk. ed. 2, I. $309(1827)^{1}{ }^{1}$

Shrub to 3 or nearly $5 \mathrm{~m}$. tall, sometimes low, rarely stoloniferous, with irregularly whorled branches; young branchlets, particularly toward the apex, with hirsute or strigose loosely appressed, rarely spreading hairs, otherwise glabrous, yellowish, or grayish brown, rarely red-brown at the end of the first season, the older branches light grayish brown; winter-buds glabrous sometimes pubescent, usually brown, with 8 to 12 broadly ovate rounded at apex and usually mucronate or sometimes without mucro, the basal scales sometimes long-pointed, ciliolate on the margin. Leaves ovate or elliptic-obovate to oblong-oblanceolate, acute or rounded and gland-tipped at apex, cuneate at base, 2 to $6 \mathrm{~cm}$. long and 0.7 to $2 \mathrm{~cm}$. broad, ciliate, glabrous on both sides except the midrib slightly villose above and more or less strigose beneath, sometimes strigillose above, particularly on leaves at the end of the shoots, usually dark green above, lighter green or glaucescent beneath, at maturity firm but rather thin; petioles 1 to $3 \mathrm{~mm}$. long, strigillose. Flowers appearing after the leaves in June or July or farther south in May, in clusters of 4 to 9 ; pedicels 0.5 to 1 , rarely to $1.5 \mathrm{~cm}$. long, pubescent and glandular-hirsute; calyx-lobes semi-orbicular to ovate, about $1 \mathrm{~mm}$. long, setosely glandular-ciliate; corolla white or more or less suffused with pink, rarely deep pink, cylindric, the tube somewhat dilated near apex, 1.5 to $2.5 \mathrm{~cm}$. long, about one and one half times as long as the lobes or sometimes little longer than lobes, rarely almost twice as long, finely villose and glandular-hirsute outside, slightly pubescent inside above the middle, the lobes ovate-oblong, acuminate, about $1.5 \mathrm{~cm}$. long, glandularhirsute along the middle outside and finely villose; stamens exserted, somewhat longer than the lobes; the filaments villose except the upper third; style 4 to $5 \mathrm{~cm}$. long, exceeding the stamens, finely pubescent below the middle or on the lower third, pale or sometimes purplish toward the stigma; ovary glandular-setose or sometimes setose and glandless. Capsule oblong-ovoid, 1.3 to $2 \mathrm{~cm}$. long, glandular-setose and finely pubescent or sometimes glandless.

The species is distributed from southwestern Maine through the coastal plain to southeastern South Carolina, extending inland to central Massachusetts, northwestern Connecticut and up the valley of the Hudson River to the neighborhood of Albany,2 northern New Jersey, central and southwestern Pennsylvania, eastern

1 Pretunnean Srnonys: Cistus Virginiana flote et odore Periclymeni Banister apud Plukenet, Phytog. t. 161, fig. 4 (1691); Almag. 106 (1696). - Azalea ramis infra foliosis Gronovius, Fl. Virg. 21 (1739), - Colden in Act. Soc. Sci. Upsala, IV. 92 (Pl. Coldengh.) (1749).

Additional Illustrations. Colored Plates: Kerner, Darst. Vorz. Ausl. Bäum. t. 57 (1796). - Meerburgh, Pl. Select. Icon. t. 9 (1798). - Schmidt, Oesterr. Baumz. III. t. 171 (1800). - Savi, Fl. Ital. II. t. 66 (1822). -Audubon, Birds Am. II. 115 (1831-34); Quarto ed. I. t. 64 (1840). - Emerson, Trees \& Shrubs Mass. ed. 2, II. t. opp. p. 438 (1875). - Meehan's Monthl. X. 81, t. 6 (1900). - BцAcK FYGdras: Loudon, Arb. Brit. II. figs. 947, 949 (1838), 947 after Loddiges t. 44, and 949 after Bot. Reg. t. 414. - Newhall, Shrubs N. E. Am. fig. 82 (1893). - Miller \& Whiting, Wild Flow. N. E. St. 381 (1895). - Keeler, Our North. Shrubs, 355 (1903).Stevens, Ill. Guide Flow, Pl. t. 114, fig. 5 (1910). - Schneider, Ill. Handb. Laubholzk. II. figs. 329 n-p, 330 c-d (1911). - Country Life Am. XI. 496 (1907). House, Wild. Fl. N. Y. II. fig. 22 (1920), as A. canescens.

2 In the state of New York $R$. viscosum has been reported as far west as Oneida County by Payne, Cat. Pl. Oneida Co. 50 (in Rep. Regents Univ. N. Y.) (1865), but I have seen so specimens from that locality and Professor K. M. Wiegand writes me that he does not know it west of the Albany region and the Catakills. 
West Virginia, western North Carolina and southeastern Tennessee and southwestern South Carolina (Oconee County). It also has been reported from northeastern Ohio. ${ }^{1}$ It forms a densely-branched shrub from 1 to 5 meters tall and grows almost exclusively in swamps together with other swamp-loving shrubs and trees; it is rather common in the swamps of the coastal plain from southwestern Maine to South Carolina, but it also is found in swamps on the higher mountains.

Rhododendron viscosum is a very variable species, but it is never pubescent except in one rare variety and in this respect differs from the otherwise very closely related $\boldsymbol{R}$. serrulatum from which it is often difficult to distinguish. With the latter species and with $R$. arborescens, $R$. oblongifolium and $R$. atlanticum, it forms a group of very closely connected species which have been frequently confused and are sometimes not easily distinguished from each other. The most distinct and least variable is $R$. arborescens, which differs from all these related species in the glabrous branchlets, glabrous leaves and usually glabrous style; $R$. atlanticum differs in its early flowers appearing before or with the leaves, in the absence of the villose pubescence of the corolla and in its low stature and stoloniferous habit; $\boldsymbol{R}$. oblongifolium differs chiefly in its usually more or less pubescent, larger and narrower, acute or sometimes almost acuminate leaves, in the usually larger calyxlobes, the larger more villose and less glandular corolla and in the always pubescent winter-buds. The most closely related species is $R$. serrulatum which might be considered only a southern variety of $R$. viscosum and in fact was not separated at all from the latter species until recently; it may be chiefly distinguished by the more chartaceous, setosely serrulate, somewhat reticulate, often pubescent leaves never glaucous beneath, the more numerous always distinctly mucronate, often aristate scales of its floral winter-buds, the longer and slenderer corolla-tube about twice as long as the lobes and the bright red-brown branchlets usually densely strigose toward the apex. Rhododendron viscosum varies in the pubescence of its winter-buds, in the amount and character of the strigose or hirsute pubescence on the branchlets and leaves, in the color and shape of the leaves which may be bright green or more or less glaucous and vary from obovate to oblong-lanceolate, in the size and color of the flowers which may be almost pure white or more or less pink, rarely deep pink. Sometimes it has the low stoloniferous habit of R. allanticum; e. g. I. Tidestrom's No. 7080, from between Berwyn and Lanham, Maryland, June 8, 1914, L. F. Ward's specimen from Terra Cotta Swamp, Washington, D. C., June 13, 1880 (Nat. Herb. No. 14,480), E. S. Steele's specimen from Hyattsville, Maryland, May 31, 1915 (Nat. Herb. No. 835,633) and Witmer Stone's No. 571, from Tyndalls Mill, south of Manning, South Carolina, May 5, 1917; also P. C. Standley's No. 11,547 from Hyattsville Swamp, May 27, 1915,

${ }^{1}$ Newberry, Cat. Pl. Ohio, 24 (1860). - Kellerman, Cat. Ohio Pl. 129 (in Rep. Geol. Surv. Ohio, VII. pt. 2) (1893). - Schaffner, Cat. Ohio Vasc. Pl. 204 (in Ohio Biol. Surv. 1.) (1914). - Rhododendron viscosum was first reported from Ohio by Newberry in 1860 without definite locality except "East." Kellerman in 1893 quotes it from Beardslee's Catalogue of 1874, where it is recorded from near Painesville. Schaffner in 1914 gives Ashtabula County as the only locality for the species. Among the Azaleas from the herbarium of the Ohio State University received through the kindness of Professor J. H. Schaffner I found only one specimen labeled Azalea viscosa L., Pymatuming Swamp, Ashtabula County, August 11, 1900, C. A. Davis, A. Dachnowski, F. Detmers. This specimen has neither flowers nor fruits and is apparently some form of $R$. roseum; it is certainly not $R$. viscosum. Beardslee's record is probably based on a similar form; Professor Schaffner writes me that there are a few of Beardslee's specimens in the herbarium of the Ohio State University, but none labeled Azalea viscosa, and that Newberry's Catalogue was not based on specimens that could be verified. 
which belongs to var. glaucum and a specimen from Fayetteville, North Carolina, Biltmore Herb. (Nat. Herb. No. 969,586) which belongs to var. nitidum. Several forms and varieties have been distinguished but on account of their mostly insufficient description and in the absence of type specimens it is not always possible to recognize them with certainty and the numerous intermediate forms make their distinction still more difficult.

Rhododendron viscosum was apparently first observed by John Banister, an English missionary who sent a drawing of it to Dr. Compton, Bishop of Iondon. Dr. Compton communicated it to Plukenet, who published it in 1691 in his Phytographia. The plant was introduced into England apparently in the first half of the 18th century by John Bartram, who sent seeds or plants to Peter Collinson, ${ }^{1}$ but the exact date is not known. According to Aiton it was introduced in 1734, but Catesby in 1731 speaks of this shrub in the text to the figure of his Cistus virginiana, which is $R$. canescens, as "having for some years past produced its beautiful and fragrant blossoms at Mr. Bacon's at Horton and at Mr. Collinson's at Peckham." I suppose Catesby confused several species, as appears from the fact that he applied Plukenet's name belonging to $R$. viscosism to his figure which represents $R$. canescens. His reference to fragrant blossoms seems to indicate that the shrub in cultivation was $R$. viscosum. In any case this species must have been well known about 1789 when Aiton enumerated five different varieties in cultivation. Wangenheim in 1787 published the first detailed description and characteristic figure; he mentions three varieties observed by him in the state of $\mathrm{New}$ York.

From the type ( $R$. viscosum a. odoratum Sweet, Hort. Brit. ed. 2, 344 [1830]. Azalea viscosa a. odorata Aiton, Hort. Kew. I. 203 [1789]. - Azalea viscosa a. virens Michaux, Fl. Bor.-Am. I. 151 [1803]), which has green leaves and the flowers white or sometimes striped pink outside along the middle of the lobes (Azalea viscosa $\beta$. vittata Aiton, Hort. Kew. 203 [1789]. - Rhododendron viscosum B. vittatum Sweet, Hort. Brit. ed. 2, 344 [1830]), the following varieties and forms may be distinguished:

\section{Rhododendron viscosum f. rhodanthum Rehder, forma nova.}

A typo recedit floribus intense roseis.

Maryland. Prince Georges County: opposite Hyattsville, eastward, May 31, 1915, E. S. Steele (Nat. Herb. No. 835,633).

District of Columbia. North of Washington, June 15, 1909, Professor Cook (Nat. Herb. No. 615,776).

This is a form of the typical variety with bright pink flowers very glandular outside. In the type specimen, which is from a low stoloniferous shrub, the very young winter-buds are glabrous outside; in Professor Cook's specimen they are silky-pubescent. This bright pink form occurs occasionally with the type, but seems to be less common than the pink form of var. glaucum.

Rhododendron viscosum var. glaucum Torrey, Fl. U. S. I. 425 (1824). - Gray, Syn. Fl. II. 1, 41 (1878). - J. Robinson, Fl. Essex Co. Mass. 73 (1880). - Dame \& Collins, Fl. Middlesex Co. Mass. 62 (1888). - Britton, Cat. Pl. N. Jersey, 162 (1889). - Coulter \& Watson, Gray's Man. ed. 6, 320 (1890). - Dudley \& Thurston, Cat. Pl.

1 See $R$. nudiflorum on page 136 . 
Lackawanna \& Wyoming Valleys, 38 (1892). - Voss, Vilmorin's Blumengärt. I. 588 (1894), as forma. - Deane, Fl. Metrop. Park, Mass. 53 (1896); in Rhodora, I. 94 (1899). - Robinson \& Fernald, Gray's New Man. ed. 7, 631 (1908). - J. Jackson, Cat. Pl. Worcester Co. Mass. 75 (1909). - Graves \& others, Cat. Flow. Pl. Conn. 308 (1910). - Stone, List Pl. Franklin, Hampshire, Hampden Cos. Mass. 48 (1913).

Azalea viscosa var. $\delta$. floribunda Aiton, Hort. Kew. I. 203 (1789). - Willdenow, Spec. I. 832 (1798).

Azalea viscosa var. $\epsilon$. glauca Aiton, Hort. Kew. I. 203 (1789). - Willdenow, Spec. I. 832 (1798). - Michaux, Fl. Bor.-Am. I. 151 (1803). - Gray, Man. 268 (1848). - M. A. Curtis, Descript. Trees \& Shrubs (in Geol. Nat. Hist. Surv.N.Car. III. Bot. 98 (1860). - Britton \& Brown, Ill. Fl. II. 560 (1897). Jelliffe, Fl. Long Island, 124 (1899). - Britton, Man. 699 (1901). Porter, Fl. Pennsylv. 239 (1903). - Keller \& Brown, Handb. Fl. Phila. 246 (1905). - Shreve \& others, Pl. Life Maryland, 466 (1910). - Stone in Ann. Rep. N. Jersey State Mus. 1910, 614 (1911). - Millspaugh, Liv. Fl. W. Virginia, 322 (in W. Va. Geol. Surv.) (1913).

Azalea glauca Lamarck, Tab. Encycl. Méth. I. 493, t. 110, fig. 2 (1791).Pursh, Fl. Am. Sept. I. 154 (1814). - De Candolle, Prodr. VII. 716 (1839). Azalea scabra Hort. ex Michaux, Fl. Bor.-Am. I. 151 (1803), as synonym.

Azalea floribunda Dumont de Courset, Bot. Cult. ed. 2, III. 334 (1811), as var. of A. viscosa.

Rhododendron glaucum Sweet, Hort. Brit. ed. 2, 344 (1830). - G. Don, Gen. Syst. III. 848 (1834). .1

This variety differs from the type in its glaucous leaves, which may be glaucous only below and green or more or less glaucescent above. Sometimes, particularly at the end of the shoots, the leaves are strigose above; the latter form was distinguished by Aiton as var. glauca from his var. floribunda with the leaves glaucous beneath and smooth above, but these two forms can hardly be kept distinct and in uniting them I follow Torrey (Fl. U.S. I. 425 [1824]) in giving preference to the name glauca which has been used for this form by all subsequent authors, though var. floribunda precedes it on the page. The flowers are either white or more or less suffused with carmine outside, of ten very intensely so before opening; the form with the more intensely pink or carmine flowers may be distinguished as f. rubescens, comb. nov. (? Azalea viscosa pubescens ${ }^{2}$ Loddiges, Bot. Cab. V. t. 441 [1820]). - A. viscosa $\eta$. rubescens Sweet, Hort. Brit. 266 (1826), name. — Loddiges, l. c. XVI. t. 1518 (1829). - Rhododendron viscosum ๆ. rubescens Sweet, Hort. Brit. ed. 2, 344 (1830). - G. Don, Gen. Syst. III. 847 (1834). — ? R. viscosum $\theta$. pubescens Sweet, Hort. Brit. ed. 2, 344 (1830). - Azalea glauca var. purpurascens Jäger, Ziergeh. 118 (1865). - Azalea glauca var. rosea Jäger, l. c. (1865). - Rhododendron viscosum f. roseum Hollick in Bull. Torr. Bot. Club, XVIII. 256 (1891).

The var. glaucum both with white and red flowers is found frequently growing together with the typical form throughout its range, at least in the coastal plain

1 Additional Illdatrations. Colored Plates: Meerburgh, Pl. Select. Icon. t. 6 (1798). - Schmidt, Oester. Baumz. III. t. 172 (1800). - Watson, Dendr. Brit. I. t. 5 (1825).

2 This is probably a mistake for rubescens; there is apparently nothing pubescent about this plant and the red color is the chief character by which it is distinguished. 
region, but I have seen no specimens of it from Maine, New Hampshire, nor from North and South Carolina. A specimen from Lee County, Alabama, seems doubtful.

Rhododendron viscosum var. nitidum A. Gray, Syn. Fl. II. 1, 41 (1878). - Ward, Guide Fl. Wash. 95 (1881). - Owen, Pl. Nantucket, 39 (1888). - Britton, Cat. Pl. N. Jersey, 162 (1889). - Coulter \& Watson, Gray's Man. ed. 6, 320 (1890). - Voss, Vilmorin's Blumengärt. I. 588 (1894), as forma. - Deane in Rhodora, I. 94 (1899); III. 197 (1901). - Fernald \& Robinson, Gray's New Man. 631 (1908).

- Graves \& others, Cat. Fl. Pl. Conn. 308 (1910).

? Azalea lucida Meerburgh, Pl. Select. Icon. t. 7 (1798).

? Azalea spathulata Dumont de Courset, Bot. Cult. III. 335 (1811), as "sousvar." of A. viscosa.

Azalea nitida Pursh, Fl. Am. Sept. I. 153 (1814). - De Candolle, Prodr. VII. 716 (1839).

Rhododendron nitidum Torrey, Fl. U. S. I. 425 (1824). - G. Don, Gen. Syst. III. 847 (1834).

Azalea viscosa var. nitida Gray, Man. ed. 2, 257 (1856). - Wood, Classb. Bot. 489 (1870); Am. Bot. Fl. 203 (1870). - Nicholson, Ill. Dict. Gard. I. 150 (1887). - Britton in Mem. Torr. Bot. Club, V. 248 (1894); Man. 699 (1901).Britton \& Brown, Ill. Fl. 560 (1897). - Jelliffe, Fl. Long Island, 124 (1899). - Porter, Fl. Pennsylv. 239 (1903). - Keller \& Brown, Handb. Fl. Phila. 246 (1905). - Millspaugh, Liv. Fl. W. Virginia, 323 (in W. Va. Geol. Surv.) (1913).

This form differs from the type chiefly in its dwarfer habit and in its smaller leaves obovate-oblong or narrowly elliptic to oblanceolate, acute at the ends or abruptly acuminate, green on both sides, sometimes strigose above. The flowers are usually more or less pinkish.

This form occurs with the type from Massachusetts to eastern North Carolina and is apparently a coastal plain form; the most southern specimens I have seen are from Newbern, Craven County, North Carolina (T. G. Harbison, Nos. 45, 46, $47,49,53,55,56$, June 6,1918 ); a specimen collected near the same locality (May 26,1919 ; No. 129) by the same collector is typical $R$. viscosum.

Rhododendron viscosum var. tomentosum Rehder, comb. nov.

Azalea tomentosa Dumont de Courset, Bot. Cult. ed. 2, III. 336 (1811), as var. of A. viscosa. - Bosse, Vollst. Handb. Blumengärt. I. 341 (1840).

? Azalea tomentosa Dur. ex Steudel, Nomencl. I. 96 (1821), as var. of A. procumbens. ${ }^{1}$

Azalea viscosa tomentosa Hort. Angl. ex Bosse, l. c. (1840), as synonym.

Marrland. Prince Georges County: Hyattsville, June 27, F. H. Knowlton (Nat. Herb. 335,818); June 4, 1905, H. D. House (No. 925 a, Nat. Herb. No. 492,824, in part).

1 The author citation "Dur." is possibly a mistake for "Dum." Duroi describes only Azalea viscosa in his Harbkesche Baumzucht. Why Steudel refers A. tomentosa to $A$. procumbens is not clear to me. 
District of Columbia. Bancroft, Four Mile Run, June 6, 1915, E. S. Steele (Nat. Herb. No. 835,632).

North Carolina. Cumberland County: Manchester, June 25, 1902, Biltmore Herb. No. 6610 (Nat. Herb. No. 969,584; shrub 6-8 ft.).

Cultivated. A specimen in the Gray Herbarium without locality labeled "28. A. tomentosa Loddiges."

This variety differs from the type chiefly in its leaves being finely but rather densely pubescent beneath and more or less so above. No reference to such a form appears in any American flora, but the plant must have been introduced to Europe more than a hundred years ago and was first described by Dumont de Courset, who was in doubt whether it was a distinct species or a variety of $A$. viscosa and describes it as having wooly branches, lanceolate-oval leaves soft-pubescent on both sides and late appearing white, fragrant flowers. Of the plant cultivated in England as A. tomentosa there is a sterile specimen in the Gray Herbarium which was probably incorporated in the herbarium between 1840 and 1850, as "Torr. and Gray, Flora N. Am." appears on the label. This specimen agrees exactly with the spontaneous specimens cited above and especially with the specimen from Hyattsville. The leaves are generally oblong-obovate, 2.5 to $5.5 \mathrm{~cm}$. long, acute or acutish, sparingly strigillose above, sparingly strigose on the midrib beneath; the petioles and young branchlets are puberulous and sparingly strigose. The leaves in the specimen from Manchester are slightly shorter and broader and more densely pubescent above and not strigillose; the corolla-tube in this specimen is slender, about $2.8 \mathrm{~cm}$. long, rather densely villose and sparingly glandular-pilose. The specimen from the District of Columbia has less densely pubescent leaves and a more glandular and less villose corolla as has the specimen from Hyattsville. This is a rather remarkable variety, as I have not observed in any of the numerous specimens of $R$. viscosum that $I$ have seen any tendency to have the leaves pubescent, although the midrib may be sometimes slightly pubescent below.

Rhododendron viscosum var. hispidum Voss, Vilmorin's Blumengärt. I. 588 (1894), as forma. - Schneider, Ill. Handb. Laubholzk. II. 502 (1911), as var. - Rehder in Bailey, Stand. Cycl. Hort. V. 2942 (1916).

? Azalea scabra Dumont de Courset, Bot. Cult. ed. 2, III. 335 (1811), as var. of $A$. viscosa.

Azalea hispida Pursh, Fl. Am. Sept. I. 154 (1814). - Watson, Dendr. Brit. t. 6 (1825). - De Candolle, Prodr. VII. 2, 716 (1839).

Rhododendron hispidum Torrey, Fl. U. S. I. 425 (1824). - Loudon, Arb. Brit. II. 1144, fig. 948 (1838). - G. Don, Gen. Syst. III. 847 (1834).

Azalea glauca $\beta$. hispida Heynhold, Nomencl. Bot. Hort. I. 108 (1840).

Azalea viscosa var. hispida Wood, Classb. Bot. 490 (1870); Am. Bot. Flor. 203 (1870). - Britton in Mem. Torr. Bot. Club, V. 248 (1894); Man. 699 (1901). - Britton \& Brown, Ill. Fl. II. 559 (1897). - Porter, Fl. Pennsylv. 239 (1903).

This form differs from the type chiefly in its hispid young branchlets, the glaucous rather narrow leaves usually strigose above and in the hispid pedicels. The flowers are usually more or less carmine and have according to Pursh frequently ten stamens. The habitat of this form which is described as a shrub 3 to $5 \mathrm{~m}$. tall 
is given by Pursh as occurring "on the borders of lakes on the highest parts of the Blue Mountains: New York and Pennsylvania"; by Britton it has been reported from Shawangunk Mountain, Ulster County, New York, and Montauk Point, Long Island, and by Porter from Monroe County, Pennsylvania, but I have not yet seen a specimen which agrees with Pursh's description. The specimen from Montauk Point I consider a rather copiously strigose specimen of typical $R$. viscosum.

\section{Rhododendron viscosum var. montanum Rehder, var. nov.}

A typo recedit gemmis floriferis perulis paucioribus sericeo-pubescentibus praeditis, ramulis minute-villosulis et praesertim apicem versus pilis longis patentibus pallidis instructis ut petioli, foliis subtus ad costam sericeo-strigillosis v. subpatentim hirsutis et satis dense v. interdum sparsissime minute villosulis vel interdum fere glabris, pedicellis dense glanduloso-pilosis.

Norte Carolina. Macon County: Highlands, alt. 3825 and 3900 ft., July 9 and September 30, 1918 (No. 58, type, No. 60); alt. 3900 ft., June 20 and September 30, 1918 (Nos. 40, 41), July 9, 1918 (No. 63), June 13, 1918 (No. 38), June 20, 1918 (Nos. 31, 36), September 2, 1910 (No. 117), June 10, 1911 (No. 650), July 2, 1911 (No. 656), T. G. Harbison; Mt. Satuloh, June 21, 1898, A. P. Anderson (No. 1507; Nat. Herb. No. 344,433). Buncombe County: Biltmore, June 12, 1897 (Biltmore Herb. No. 1399 a), vicinity of Black Mountain, Sept. 8, 1913, P. C. Standley \& H. C. Bollman (No. 10,453; Nat. Herb. No. 689,191). Wake County: Raleigh, June 11, 1918, T. G. Harbison.

This variety differs from the type chiefly in its pubescent winter-buds with comparatively few scales, in the spreading hairs and the minute pubescence of the branchlets and pedicels and of the midrib of the under side of the leaves. It is a low densely branched shrub, usually not exceeding $1.25 \mathrm{~m}$. in height. The silkypubescent winter-buds have only 5 to 7 larger broad rounded scales with 3 to 4 small acuminate scales at the base. The young branchlets are minutely puberulous and toward the apex more or less densely furnished with long spreading pale hairs not brown and loosely accumbent as on the otherwise glabrous branchlets of the typical plant. The leaves are obovate to oblong-obovate, 2.5 to $4 \mathrm{~cm}$. long, glabrous and bright green somewhat lustrous above, the terminal leaves very rarely strigose, lighter or paler green beneath, the midrib with long pale subaccumbent or sometimes more or less spreading hairs and besides usually minutely villose particularly toward the base; the very short petioles have a pubescence aimilar to that of the branchlets. The flowers appear from the middle of June to the beginning of July; their pedicels are finely villose and rather densely glandular-pilose; the corolla is finely villose and furnished with numerous red long-stipitate glands and seems to be usually more or less suffused with pink; the calyx-lobes are very short; the style is purplish above, with purple stigma. The capsule is oblongovoid, 0.8 to $1.5 \mathrm{~cm}$. long, finely villose and glandular-setose. The variety seems to be similar to and may be identical with Azalea hispida of Pursh, which is also a mountain form of $\boldsymbol{R}$. viscosum; but Pursh describes his plant as 10 to 15 feet tall, the leaves as hispid above and the calyx-teeth as oblong, while this variety is a low shrub, with the leaves smooth above or only very exceptionally strigillose above, and the calyx-teeth very short. 
This variety is apparently restricted to the mountains of North Carolina and grows in swamps or sometimes in woods or on mountain slopes. It was introduced into cultivation through the Arnold Arboretum, where plants were raised from seed collected in January, 1919, by Mr. T. S. Harbison near Highlands. With it grows a form with glaucescent leaves and often more intensely pink flowers which may be distinguished as:

Rhododendron viscosum var. montanum f. coerulescens Rehder, f. nov.

A typo recedit foliis subtus glaucis et supra glaucescentibus vel opace coeruleoviridibus et floribus saepius plus minusve roseis.

North Carolina. Macon County: Highlands, alt. 3825 and $3900 \mathrm{ft}$., July 9 and September 30, 1918 (No. 66, type, Nos. 57 and 65), June 17, 1918 (No. B 39), June 19, 1918 (No. 35), September 2, 1920 (No. 116), July 14, 1920 (No. 5845), T.G.Harbison. Avery County, Linville (Plant collected by H. H. Richardson and cultivated in his garden; specimen June 28, 1918). Transylvania County : Little Pisgah Mountain, alt. 5100 ft., June 24, 1909, H. D. House (No. 4311; Nat. Herb. No. 513,348). Buncombe County: Asheville, May, 1888, G. McCarthy (Nat. Herb. No. 42,623).

This form appears quite distinct with its bluish green leaves glaucous beneath and the more or less pink flowers which are in the plant brought by Mr. Richardson from Linville in 1913 carmine in bud and suffused with rosy pink all over when open. As an ornamental shrub it is certainly one of the handsomest forms of Rhododendron viscosum.

Rhododendron viscosum var. aemulans Rehder, var. nov.

A typo praecipue recedit foliis majoribus latioribusque ad $6 \mathrm{~cm}$. longis et ad $3.5 \mathrm{~cm}$. latis, subtus glaucescentibus v. pallidis plerumque obovatis saepe obtusiusculis, ramulis praesertim apicem versus dense ferrugineo-strigosis, floribus majoribus, tubo fere $3 \mathrm{~cm}$. longo satis dense villoso, perulis dense griseo-sericeis.

Georgis. Randolph County: in low woods near Cuthbert, May 9, 1918, T. G. Harbison (No. 39, type, Nos. 36, 37, 38). Here may also belong Harbison's Nos. 17 and 20, Cuthbert, low shrub in burned-over pine woods, March 29, 1918.

This is a very perplexing form and seems to be equally closely related to $R$. viscosum, $R$. serrulatum var. georgianum and $R$. oblongifolium. From the first it differs chiefly in the larger leaves glaucescent beneath, the densely rufous-strigose branchlets, the larger rather densely villose flowers and the densely pubescent winterbuds; from the second it differs in its early flowering time, the more villose corolla, and from the third in the densely rufous-strigose branchlets, destitute or nearly destitute of villose pubescence, in the more densely glandular corolla and in the small sepals. The winter-buds are densely grayish pubescent. The leaves are obovate to nearly elliptic often almost rounded at the apex, mucronulate, 3 to 6 $\mathrm{cm}$. long and 1.5 to $3.5 \mathrm{~cm}$. broad, glabrous above, the upper ones narrower and acute and strigillose above, pale or glaucescent beneath and glabrous except the 
strigillose midrib, and slightly reticulate. The flower-clusters are large and manyflowered; the sepals semiorbicular and minute; the corolla-tube is about $3 \mathrm{~cm}$. long, villose and glandular-hirsute; the setose hairs of the ovary are tipped with purple glands. Part of No. 36 consists of a branch with the leaves narrower and puberulous above and short-villose beneath. Whether the numbers 17 and 18 collected in bloom on March 29 belong here is doubtful. The leaves are half-grown, glaucescent on both sides and glabrous except the strigillose midrib beneath, the corolla is less pubescent and the tube somewhat more gradually dilated at the apex. It has some resemblance to $R$. atlanticum, but the corolla is less glandular and more villose, the winter-buds are pubescent and the habit is apparently different. Some specimens from Lee and Dallas Counties, Alabama, which I have referred to typical $R$. viscosum, may belong rather to this variety than to $R$. viscosum.

Aiton's Azalea viscosa r. fissa (Hort. Kew. I. 203 [1789]. - Rhododendron viscosum ı. fissum Sweet, Hort. Brit. ed. 2, 344 [1830]) described as "floribus albis ad basin usque divisis, foliis saturate viridibus lucidis" is apparently not a form with a regularly five-parted corolla like his $A$. nudiflora $\eta$. partita, for Dumont de Courset describes the same form under Azalea serotina N., A. fissa H. K. (Bot. Cult. ed. 2 , III. 336 [1811]), as follows: "Le tube de la corolla est plus court; le limbe se fend quelquefois dans une des ses divisions jusqu'au tiers ou la moitié du tube, même jusqu'à sa base; dans plusieurs corolles il ne se fend pas." Such split corollas may be seen occasionally and seem to occur in certain individuals more frequently than in others; for instance Harbison's No. 656 of var. montanum shows a large percentage of more or less deeply split corollas, but this can be considered only as an abnormality and not as a taxonomic form.

A form with double flowers is mentioned by Dumont de Courset in 1814 (Bot. Cult. VII. 166) as "Azalea visqueuse à fleurs doubles," and in 1864 Kirchner (in Petzold \& Kirchner, Arb. Musc. 479 [1864]) enumerates an Azalea viscosa flore pleno. I have seen neither a plant nor a specimen of a double-flowered true $R$. viscosum; the forms I have seen under this name were apparently of hybrid origin. There is also an Azalea glauca flore semipleno Jäger (Ziergeh. 118 [1865]). - Azalea viscosa glauca sousvar. flore pleno Mouillefert, Arb. Arbriss. II. 1021 [1897]. —? Azalea glauca plena Hort. Kew. [in herb. Arnold Arb.]. Under the last named gynonym a specimen was collected by G. Nicholson in Kew Gardens in 1880; the leaves are glaucescent beneath and the corolla has the shape of that of $R$. viscosum, but it is almost destitute of villose pubescence, the sepals are well developed and oblong and the young branchlets are almost glabrous except stipitate glands. These characters, together with the early flowering time (June 1) when the leaves were only partly developed, suggest $R$. atlanticum.

Rhododendron arborescens Torrey, Fl. U.S. 425 (1824). - G. Don, Gen. Syst. III. 847 (1834). - Loudon, Arb. Brit. IV. 1145 (1838). Gray, Syn. Fl. II. 1, 40 (1878). — Sargent, Gard. \& For. I. 400, fig. 64 (1888). - Dippel, Handb. Laubholzk. I. 416, fig. 269 (1889). - Coulter \& Watson, Gray's Man., ed. 320 (1890). - Robinson \& Fernald, Gray's New Man. ed. 7, 631 (1908). - Schneider, Ill. Handb. Laubholzk. II. 500, fig. $329 \mathrm{l}-\mathrm{m}, 330$ b (1911). - Millais, Rhodod. 115 (1917).

? Azalea viscosa Marshall, Arbust. Am. 15 (1785), not Linnseus.

Azalea arborescens Pursh, Fl. Am. Sept. 152 (1814), - De Candolle, Prodr. VII. 2, 716 (1839). - Gray, Man. 268 (1848); ed. 5, 299 (1867). - M. A. 
Curtis, Descript. Trees \& Shrubs (in Geol. Nat. Hist. Surv. N. Car. III. Bot.) (1860). - Britton \& Brown, Ill. Fl. II. 559, fig. 2746 (1897). - Britton, Man. 698 (1901). - Gattinger, Fl. Tenn. 131 (1901). - Porter, Fl. Pennsylv. 238 (1903). - Keller \& Brown, Handb. Fl. Phila. 246 (1905). - Small, Fl. S. E. U.S. 883 (1903); in N. Am. Fl. XXIX. 43 (1914). - Millspaugh, Liv. Fl. W. Virginia, 322 (in W. Va. Geol. Surv.) (1913).

Azalea verticillata Carr, Cat. Trees \& Shrubs Bartram's Bot. Gard. 11 (1814), name only. - Loddiges, Bot. Cab. XVII. t. 1632 (1830).

Azalea arborea Bartram ex Pursh, Fl. Am. Sept. 152 (1814), as synonym.

Azalea fragrans Rafinesque, Ann. Nat. 12 (1820), not Adams. ${ }^{1}$

Upright shrub to $3 \mathrm{~m}$., rarely a small tree $6 \mathrm{~m}$. tall; young branchlets glabrous or rarely with a few scattered strigose hairs, often slightly bloomy, yellowish brown or reddish brown at the end of the first season, becoming light gray or light grayish brown the second year; floral winter-buds glabrous, light brown, with broadly ovate rounded and usually mucronulate ciliate scales. Leaves obovate or sometimes elliptic to oblong-oblanceolate, acute or obtuse and gland-tipped at the apex, cuneate at base, 3 to $8 \mathrm{~cm}$. long and 1.3 to $3 \mathrm{~cm}$. broad, ciliate, lustrous bright green above, glaucous or glaucescent or sometimes nearly green beneath, glabrous except sparingly short-villose on the midrib above and sparingly strigose on the midrib beneath or sometimes quite glabrous beneath; petioles slender, 3 to $7 \mathrm{~mm}$. long, glabrous or rarely with a few strigose hairs. Flowers very fragrant, appearing the end of June or beginning of July in 3- to 6-flowered, umbel-like clusters; pedicels slender, 0.8 to $2 \mathrm{~cm}$. long, glandular-hirsute or without glands, sometimes glabrous; sepals ovate to linear-oblong, usually obtuse, 3 to $6 \mathrm{~mm}$. long, glandular-ciliate, otherwise glabrous or sometimes villose; corolla funnel-form, white or pinkish, the tube 2.5 to $3 \mathrm{~cm}$. long, slightly dilated at the apex, usually sparingly, rarely densely glandular-hirsute outside, otherwise glabrous or slightly, rarely rather densely villose, pubescent inside except on the lower third, lobes ovateoblong, acuminate 1.5 to $2 \mathrm{~cm}$. long; stamens exserted about twice as long as the tube, the filaments purple above, pubescent below the middle; anthers 2 to $3 \mathrm{~mm}$. long, ochraceous; style as long or somewhat longer than the stamens, 5.5 to $7 \mathrm{~cm}$. long, purple above, glabrous or sometimes finely pubescent near the base, rarely villose on the lower third; ovary glandular-setose, with reddish glands. Capsule oblong-ovoid, 0.8 to $1.7 \mathrm{~cm}$. long, densely glandular-hispid.

This species is distinctly a species of the Appalachian Mountain regions and does not oecur in the coastal plane but along the Susquehanna it descends to the southern part of Lancaster County, Pennsylvania, along the Potomac to Fairfax County, Virginia, along the Savannah River to Richmond County, Georgia, and along the Chattahoochee River to Decatur County, Georgia; it is distributed from southern Pennsylvania through western Maryland, northern and western Virginia, eastern West Virginia, and eastern Kentucky, western North Carolina, northwestern South Carolina, eastern Tennessee to northern (Winston County) and eastern Alabama (Talladega and Clay Counties) ${ }^{2}$ and to eastern (Richmond County) and southwestern Georgia (Decatur County). It grows chiefly on the banks of mountain streams, rarely on the borders of swamps and ascends to an altitude of 5200 feet on the mountains of North Carolina.

1 Additional Illostrations. Colored Plate: Lounsberry, Guide to Trees, t. 75 (1900). - Black Figdres: Keeler, Our North. Shrubs, 353, fig. (1903). - Garden Mag. V. 219, fig. (1907). - Country Life Am. XI. 496 (1907). - Bailey, Stand. Cycl. Hort. V. f. 3388 (1916), after Gard. \& For.

2 Sheet No. 770,587 in the National Herbarium labeled "Rhododendron viscosum, borders of stream in thickets, Pointclear, C. Mohr, June 16, 1889," contains 
Rhododendron arborescens is most nearly related to $R$. viscosum, but is easily distinguished from this and other Azaleas by the glabrous branchlets, glabrous leaves glaucous beneath and the large white or pinkish flowers. It shows little variation except in the length and shape of the sepals, in the amount of pubescence on the outside of the corolla, in the pubescence of the pedicels occasionally quite or nearly glabrous, in the pubescence of the style, which is glabrous or sometimes more or less pubescent below.

Rhododendron arborescens was probably discovered by John or William Bartram and appeared, according to Pursh, in Bartram's catalogue as A zalea arborea, while in the catalogue issued by Robert Carr in 1814 it appears as $A$. verticillata; also "A zalea caroliniana, Sweet Honeysuckle," in an undated "Catalogue of American trees and shrubs . . . in John Bartram's Garden" may possibly be the same species. Also Humphrey Marshall seems to have known it, for his Azalea viscosa (Arbust. Am. 15 [1785]), which he describes as a shrub five or six feet high growing in rich rocky places near streams of water, is probably $R$. arborescens, while his $A$. enscosa palustris is the true $R$. viscosum.

Michaux observed it in May, 1795 (see his Jour. ed. Sargent, 116), on the Blue Ridge in North Carolina, but there seems to be no specimen of it in his herbarium. Loddiges, who published an excellent colored plate of this species under the name Azalea verticillata, states that it was received "many years since from our old friend Bartram under this name," which tends to show that it was introduced before the plant was known as $A$. arborescens and before 1818, the date given by Sweet in his Hortus Britanicus under A. arborescens as the date of its introduction to England, but neither Sweet nor Loudon say who introduced it at that date; probably it was John Lyon, who was an active collector in North America up to that time. It was first described in 1814 as a new species by Pursh, who discovered it on the Blue Mountains of Pennsylvania, and also saw it cultivated in John Bartram's garden at Philadelphia; he called it the finest ornamental shrub he knew. It certainly is a very handsome shrub and it seems strange that it is still so little known in cultivation; the dry leaves have a very pleasing smell of coumarin, like Melilotus and Anthoxanthum, and retain it for many years in herbarium specimens.

\section{Rhododendron arborescens var. Richardsonii Rehder, var. nov.}

A typo praecipue recedit statu humiliore plerumque $0.60-1.5$, rarius ad $2.5 \mathrm{~m}$. altum, foliis paulo minoribus et magis glaucescentibus, corolla densius villosa et magis glanduloso-hirsuta, sepalis plerisque brevibus ovatis vel semiorbicularibus extus villosis, stylo plerumque in triente inferiore dense villoso.

North Carouna. Macon County: on Wayoh Bald, alt. 5200 feet, June 7, 1919, T. G. Harbison (No. 170, type, compact shrub, 4 feet tall, growing in dense patches), alt. 4800 feet (No. 176); Highlands, on mountain side in moist soil, alt. 4400 or 4500 feet, June 23, 1918, T. G. Harbison (Nos. G 34, D 42); alt. 4000 feet, July 9, 1918, T. G. Harbison (No. 62); without precise locality, alt. 3800 feet, July 2 , 1911 (No. 655); high mountains, Sept. 2 and 6, 1910 (Nos. 114, 132),

two different species, one being $R$. arborescens. If the locality, which is not clearly written, is Pointclear, Baldwin County, the range of $R$. arborescens would extend to the coast of Alabama, but until the occurrence of the species there is confirmed by other collections I consider it doubtful. 
alt. 48,500 feet (No. 5788), alt. 4800 feet (No. 5790), July 1, 1920, alt. 3800 feet (Nos. 5841, 5842), alt. 4000 feet (No. 5843), alt. 4500 feet (No. 5844), T. G. Harbison.

This is the form of the high mountain which replaces the typical tall-growing form at altitudes of from 3800 to 5200 feet. It is a low compact or wide-spreading shrub, usually about $1 \mathrm{~m}$. but occasionally up to $2.5 \mathrm{~m}$. tall. The leaves are somewhat smaller and more glaucous. The corolla is rather densely villose and copiously glandular-pilose outside, but slightly villose in Nos. 5790,5841 and 5842; the sepals are usually short, but sometimes, as in Harbison's Nos. G. 34 and D. 42, they are as long as in the type; the style is densely villose on the lower third except in Nos. $62,655,5790,5841,5842$, and 5844 , which have a glabrous or nearly glabrous style; the leaves are glaucous beneath, but green in No. 5843 .

What appears to be the same form has been collected near Great Falls, Fairfax County, Virginia, by Mr. W. W. Ashe (see Bull. Torr. Bot. Club, XLVII. 582 [1920]), who kindly sent us a specimen which agrees in every respect with the mountain form described above.

The variety Richardsonii was introduced into cultivation in 1917 by Mr. H. H. Richardson, who has in his garden at Brookline, Mass., an interesting collection of spontaneous forms of American Azaleas.

Rhododendron prunifolium Millais, Rhodod. 230 (1917). - Millais \& Williams in Rhodod. Soc. Notes, I. 125 (1918). ${ }^{1}$

Azalea prunifolia Small, Fl. S. E. U.S. ed. 2, 1356 (1913); in Fl. N. Am. XXIX. 44 (1914).

Slender shrub to $3 \mathrm{~m}$. tall with irregularly whorled branches; young branchlets glabrous, dark purplish red, rarely light grayish brown at the end of the first season, becoming light grayish brown or grayish the second year; winter-buds glabrous, light brown or reddish brown, with broadly ovate scales rounded and mucronulate, sometimes nearly aristate at the apex and ciliolate. Leaves elliptic, or sometimes obovate to oblong, acute or short-acuminate and gland-tipped, cuneate or broadly cuneate at base, 3 to $10 \mathrm{~cm}$. or occasionally to $13.5 \mathrm{~cm}$. long and 1.7 to $4 \mathrm{~cm}$. broad, ciliate, dark or bright green, glabrous above except the slightly villose midrib and dull green, very rarely sparingly strigillose, lighter green beneath and sparingly strigose on the midrib and sometimes on the veins, midrib and secondary veins often rather prominent beneath and light-colored, slightly impressed above; petioles 3 to $6 \mathrm{~mm}$. long, glabrous or rarely sparingly strigose. Flowers about the middle of July in 4 to 5-flowered umbel-like clusters; pedicels about $5 \mathrm{~mm}$. long, hirsute; sepals semi-orbicular to ovate, about $1 \mathrm{~mm}$. long, long-ciliate; corolla funnel-form, crimson, the tube gradually widened above the middle, 2 to $2.5 \mathrm{~cm}$. long, glabrous or sparingly hirsute, pubescent inside, the lobes broadly ovate, abruptly acuminulate, about $1.5 \mathrm{~cm}$. long and 0.9 to $1.3 \mathrm{~cm}$. broad and more or less finely villose and sometimes slightly glandular-pilose outside; stamens much exserted, nearly three times as long as the tube, 5 to $6.5 \mathrm{~cm}$. long, villose on and below the middle; anthers 2 to $3 \mathrm{~mm}$. long, ochraceous; style much exceeding the stamens, about $8 \mathrm{~cm}$. long, glabrous, purple above; ovary covered with long setose, glandless hairs. Capsule ovoid-oblong, about $2 \mathrm{~cm}$. long, strigose and finely puberulous.

${ }^{1}$ Rhododendron prunifolium Forbes, Hort. Woburn, 91 (1833), is a nomen nudum and cannot invalidate Millais' combination. 
This plant is known only in southwestern Georgia and eastern Alabama and grows in shady ravines on the banks of streams. The type locality is about two miles northwest of Cuthbert, where it was collected by $R$. M. Harper in 1903 and first described by Small in 1913. It is the most distinct of the American species of the section Pentanthera and shows no very close relation to any species of this section. It is the most glabrous of all American species and entirely destitute of any glandular pubescence except occasionally some glands on the outside of the corolla-lobes; in its glabrousness it comes nearest to the preceding species, but that has generally obovate smaller leaves distinctly glaucous beneath and a glandular and pubescent corolla; in the leaves, the winter-buds and in the branchlets it resembles $R$. Vaseyi so much that it is not easy to distinguish sterile specimens, but the flowers are entirely different. The shape of the corolla of $R$. prunifolium is much like that of $R$. calendulaceum and $R$. occidentale, but these species differ widely from $\boldsymbol{R}$. prunifolium in most other characters.

Rhododendron prunifolium was introduced into cultivation through the Arnold Arboretum, where plants were raised in 1918 from seeds collected by T. G. Harbison near Cuthbert, Georgia, in November, 1917. 


\section{ENUMERATION OF THE SPECIES}

\section{SPONTANEOUS HYBRIDS}

No spontaneous Azalea hybrids have been as yet recorded, but I have before me several specimens which may possibly be of hybrid origin. There are some specimens collected by Professor C. S. Sargent near Bath, Georgia, on April 29, 1914, which appear intermediate between $R$. canescens and $R$. speciosum. They differ from the former in the red flowers with shorter more dilated corolla-tube destitute of glands and with larger limb and from $R$. speciosum in their smaller flowers, more densely pubescent leaves and more or less pubescent winter-buds. As the two supposed parent species have been collected at the same locality, and flower at about the same time, the occurrence of such a hybrid is not improbable. Possibly of the same origin is 'T. G. Harbison's No. 900 from Stone Mountain, De Kalb County, April 29, 1912; it much resembles $R$. speciosum, but the flowers are apparently of much lighter color and the winter-buds are pubescent; both supposed parent species occur in the region.

On the Nantahala Mountains, Macon County, North Carolina, T. G. Harbison collected a specimen (No. 186; June 7, 1919) similar to $R$. calendulaceum but with narrower and longer corolla-tube and pink flowers; it may possibly be a hybrid between $R$. calendulaceum and $R$. nudiflorum, but I am not aware whether the latter species is found in that particular locality, though it occurs in Macon County: On the Chilhowee Mountain, Tennessee, A. H. Curtiss collected an Azalea (No. 1719) which resembles closely $R$. arborescens, but has pubescent branchlets; whether this is a hybrid possibly with $R$. viscosum, I am not prepared to say. 


\section{GARDEN HYBRIDS}

There exists in gardens, especially in Europe, on the Continent as well as in England, a bewildering variety of Azaleas which are undoubtedly of hybrid origin; in fact almost all of the so-called hardy Azaleas in cultivation are hybrids, the true species having almost entirely disappeared from gardens. The parentage of most of these forms is so mixed that it is impossible to recognize their origin with certainty, particularly if one is not sure of at least one of the parents. The difficulty is increased, as pointed out before, by the absence of strong morphological characters between the different species of this group, so that it is sometimes difficult to separate even the spontaneous forms satisfactorily. Many of the older hybrids have been figured, but usually without adequate description and with often vague and indefinite indication of the parentage; and as no herbarium material is available to supplement the illustrations, we have to depend on the figures and the indication of the parentage as given. Some of these older forms may still be in cultivation, and if one were able to observe and compare a large collection of them in cultivation, many of the problems might be solved, though the only sure way to elucidate the origin of these hybrids would be by raising plants from seed of selffertilized flowers, that is from flowers carefully protected from foreign pollination and fertilized by pollen from the same plant. In some cases it may be necessary to raise more than one generation to arrive at satisfactory results. All I can do here is to assemble the more important literature relating to these hybrids as a basis for further studies.

It seems rather strange that the first hybrids known to have been raised in this genus are not between species of the Azalea group, but between Azaleas and true Rhododendrons. The very first hybrid which we know is one raised between Rhododendron ponticum and some form of Azalea; it originated at Thompson's Nursery at Mile End near London before 1800 and was figured by Andrews in 1801 as $R$. ponticum var. deciduum. This is possibly the plant distributed afterwards as $R$. azaleoides by English nurserymen, for in 1811 and 1814 Dumont de Courset describes an identical or very similar form under that name, giving "Hort. lond." as author citation. Similar crosses have 
been made afterwards during the first quarter of last century, for distinct forms of similar origin appeared in horticultural literature at that time, $e$. $g$., a cross between $R$. viscosum and $R$. maximum published by Ker in Botanical Register (t. 195) in 1817 and a cross between $R$. viscosum and $R$. ponticum published by Sims in Botanical Magazine (t. 2308) in 1822, both raised by Wm. Herbert at Spofforth, England, and other forms of unknown origin partly cultivated under the name $R$. azaleoides. Many such hybrids were raised at Coombe Wood and at Highclere, as a report in the Edinburgh New Philosophical Journal (VI. 193) in 1829 shows: "It has been found that different species in the genera Azalea, Rhododendron and Rhodora fertilize each other . . . this has occurred at the Earl of Liverpool's collection at Coombe Wood and still more remarkably at the Earl of Caernarvon's [sic] extensive collection at High Clerc [sic]," and at the same place Mr. Gowen mentions that there are hundreds of seedlings of different varieties of Azalea nudiflora and $A$. viscosa fertilized with pollen of a Rhododendron intermediate between $R$. ponticum and $R$. catawbiense.

The raising of hybrids between different species of Azaleas seems to have been started almost simultaneously in England and in Belgium. In England it was chiefly at Highclere in the Earl of Carnarvon's gardens where these hybrids were raised. In a report in the Edinburgh New Philosophical Journal (X. 185) in 1831 it is stated that Mr. Gowen raised seedlings of Azalea coccinea var. major, minor and rubescens" "dusted with pollen of a late $A$. pontica" and of $A$. coccinea rubescens ${ }^{2}$ "impregnated with pollen of $A$. calendulacea triumphans." In Belgium it was a baker at Ghent, P. Mortier, who conceived about 1825 the idea of retarding the early flowering varieties, which are often injured by late frosts, by crossing them with late flowering varieties, and he achieved splendid results. In 1834 he sold his last seedlings to Louis Verschaffelt of Ghent, who continued the work. By Sweet, who figured one of these hybrids in 1831, they were called $R$. Mortieri and later by Spae and Morren Azalea Mortieriana.

These hybrids were chiefly crosses between the American Azaleas,

1 This is probably a mistake and should read $A$. viscosa var. rubescens, for in 1832 Sweet states (Brit. Flow. Gard. ser. 3, II. t. 137) under $R$. ornatum, that the specimen figured was received in 1830 and that "the seeds were raised by Lord Carnarvon's gardener from Azalea viscosa rubescens fertilized by $A$. pontica under Mr. Gowen's own inspection."

${ }^{2}$ Lindley (in Bot. Reg. XVI. t. 1366 [1830]) states under A. calendulacea subcuprea, quoting from Mr. Gowen's letter, that this form was raised at Highclere between $A$. nudiflora rubescens and $A$. calendulacea triumphans. There is no such name as $A$. coccinea mubescens known to me. 
$R$. calendulaceum, $R$. nudiflorum, $R$. speciosum, $R$. viscosum and the Old World $R$. luteum. An interesting hybrid was raised by the Rev. William Herbert at Spofforth by crossing $R$. luteum and $R$. canadense, the species representing two different sections; it was figured by Lindley in 1838 as Azalea Seymouri, but apparently disappeared soon from cultivation, as it had no particular ornamental merits.

After R. molle G. Don (Azalea sinensis Lodd.), introduced in 1823 from China, had found its way into the gardens it also was used to produce new hybrids, and a hybrid with $R$. viscosum was figured as Azalea altaclarense in 1842, one with $R$. speciosum as Azalea marginata in 1835 and one with a form of $R$. Mortieri was figured in 1845 as $A$. sinensis var. Bylsiana. The influence of $R$. molle, however, does not seem to have left a perceptible trace among the older Azalea hybrids, but when crossed with $R$. occidentale A. Gray introduced about 1850, which was used by Anthony Waterer of Knap Hill and by others in hybridization work with this and other hardy Azaleas, a very handsome race of hardy free-flowering Azaleas with large flowers of prevailingly light colors was developed, classed here under $R$. albicans. A still greater influence on the development of hybrid Azaleas took place when $R$. japonicum was introduced into the gardens in the early sixties. It became soon widely known under the name Azalea mollis and by hybridizing it with other hardy Azaleas a distinct race known as "Azalea mollis hybrids" ( $R$. mixtum) was raised, characterized by low compact habit and dense clusters of large scentless flowers with a wide limb and short tube. Among the "Mollis hybrids" are often included the hybrids of $R$. japonicum with $R$. sinense for which the name $R$. Kosterianum has been proposed; the first hybrids of this kind appear to have been raised in the seventies (see p. 97). About 1890 another race of hybrids was raised by crossing $R$. japonicum with evergreen Rhododendrons (see p. 99); these were called by André "Azaleodendron." Recently an interesting hybrid between two different sections was raised by G. Fraser of Ucluelet, Vancouver, B. C., by crossing $R$. japonicum with $R$. canadense. This promises to be a very ornamental plant unlike the older $R$. Seymouri, the first known hybrid of $R$. canadense.

In the following enumeration the different garden forms are placed under their supposed parents, though in many cases it is not certain whether the parentage given in the original description or the opinion based on the evidence presented is correct. If an available binomial exists, it follows the indication of the parentage and is printed in 
heavy type. No attempt has been made to have binomial designations for all the different crosses; only when the plant is known to be still in cultivation and had no available name under Rhododendron, new combinations have been formed. The hybrids between old World species have been included, as far as they have not been mentioned in the preceding paper by my colleague, E. H. Wilson, to make the enumeration of the Azalea hybrids as complete as possible. 


\section{SECT. PENTANTHERA}

Rhododendron calendulaceum $\times$ nudiflorum (and partly $\times$ speciosum) = Rhododendron Mortieri Sweet, Hort. Brit. ed. 2, 343 (1830), as $R$. Morterii, name only.

Rhododendron Morterii var. a. carnea Sweet, Hort. Brit. ed. 2, 343 (1830), name only; Brit. Flow. Gard. ser. 2, I. t. 10 (1831).

Azalea calendulacea Ł. Morterii De Candolle, Prodr. VII. 718 (1839).

Azalea Mortieriana Spae in Ann. Soc. Agric. Bot. Gand, II. 325, t. 81 (1846), in part.

"Azaleae Mortierianae" Morren in Ann. Soc. Agric. Bot. Gand, III. 9, t. 106 (1847), in part.

Azalea Mortieri K. Koch, Dendr. II. 190 (1872), as synonym.

Rhododendron calendulaceum var. Morteri Nicholson in Kew Hand-list Arb. ed. 2, 497 (1902).

Rhododendron Mortieri Zabel in Mitteil. Deutsch. Dendr. Ges. XI. 30 (1902).

This is stated by Sweet to be a hybrid of and intermediate between $R$. calendulaceum and $\boldsymbol{R}$. nudiflorum and judging from the colored plate there is no reason to doubt that statement. The pink flowers are large with spreading limb consisting of broad lobes of which the upper is almost covered by an orange-yellow blotch. From this form named $a$. carnea, which must be considered the type, the form praestans differs in its pale copper-colored flowers tinged with blush and with the upper lobe of the limb coppery yellow. Sweet states that this plant was received from the Continent under the adopted specific name.

Of the aame parentage and probably referable here as synonyms or varieties are the following forms:

Azalea calendulacea a. flammea Sims in Bot. Mag. XLVII. t. 2143 (1820), not Michaux.

The plant figured is apparently neither $R$. speciosum nor a true $R$. calendulaceum; the pink corolla tube and the partly pink, partly orange-colored lobes, except the upper one which is entirely orange, may be taken to indicate the influence of $R$. nudiflorum, though there is a possibility that a variation of $R$. calendulaceum with more or less pinkish fowers exists.

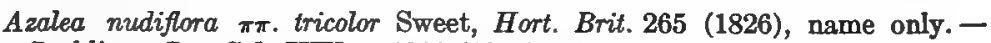
Loddiges, Bot. Cab. XIV. t. 1382 (1828).

? Azalaea tricolor Carr, Cat. Trees \& Shrubs Bartram's Bot. Gard. 10 (1814), name only.

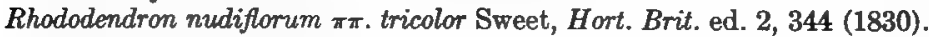

Rhododendron tricolor Sweet, Hort. Brit. ed. 2, 343 (1830), "Hybrid 1816." Millais, Rhodod. 255 (1917).

This form is stated to have been received from Philadelphia in 1821, but it belongs apparently to this group of hybrids; the rather slender deep red tube and 
the pale pink limb indicate a $R$. nudiflorum form, while the rather broad and large limb with an orange-yellow lobe indicates the influence of $\boldsymbol{R}$. calendulaceum.

Azalea calendulacea var. subcuprea Gowen apud Lindley in Bot. Reg. XVI. t. 1366 (1830).

Rhododendron calendulaceum ı. subcupreum Sweet, Hort. Brit. ed. 3, 443 (1839).

This form, which has flowers very similar in shape to those of $R$. calendulaceum and of a peculiar dull salmon-pink with an orange-colored upper lobe, is said to have been raised at Highclere between $A$. nudiflora rubescens and $A$. calendulacea triumphans, which is apparently correct.

Azalea calendulacea var. lepida Gowen apud Lindley in Bot. Reg. XVII. t. 1402 (1831).

Rhododendron calendulaceum к. lepidum Sweet, Hort. Brit. ed. 3, 443 (1839).

This form, which has flowers similar in shape to those of $R$. calendulaceum but with bright pink tube, white lobes bordered with light pink and with a large yellow blotch on the upper lobe, is stated to have been raised of the same parentage as var. subcuprea.

Azalea calendulacea var. Stapletoniana Lindley in Bot. Reg. XVII. t. 1407 (1831).

Rhododendron calendulaceum $\mu$. Stapletonianum Sweet, Hort. Brit. ed. 3, 443 (1839).

The flowers are similar to those of the preceding varieties, but of bright deep rose color with a large yellow blotch on the upper lobe. This is also one of the Highclere Azaleas, but its particular parentage is not stated.

Azalea pontica var. versicolor Lindley in Bot. Reg. XVIII. t. 1559 (1833).

Rhododendron flavum $\zeta$. versicolor Sweet, Hort. Brit. ed. 3, 442 (1839).

Though this hybrid which was raised at Highclere was published without indication of its parentage as a variety of Azalea pontica, I cannot see any indication of $R$. luteum in it. The flowers are rose-red in different shades with a deep orange upper lobe and the tube is conspicuously pilose. A specimen before me collected at Kew in 1880 and labeled Azalea versicolor grandiflora may be this form. It resembles more a form of $R$. nudiflorum; the corolla is very pilose and only sparingly glandular and the leaves do not show the slightest influence of $R$. luteum in their pubescence and shape.

\section{Rhododendron luteum $\times$ nudiflorum.}

Rhododendron calendulaceum var. fulgidum Hooker in Bot. Mag. LXII. t. 3439 (1835).

Azalea calendulacea var. fulgina Mouillefert, Arb. Abriss. II. 1022 (1897).

Azalea calendulacea var. frigida Mouillefert, $l$. $c$.

Hooker states, this Azalea was received from the Glasgow Botanic Garden as Azalea calendulacea var. fulgida, but that it has the appearance of a hybrid between $\boldsymbol{R}$. ponticum (probably a mistake for Azalea pontica) and $\boldsymbol{R}$. nudiflorum var. coccineum. It certainly does not belong to $R$. calendulaceum, and may be either a form of $R$. nudiflorum or, as Hooker suggests, a hybrid of that species with $R$. luteum. The flowers are bright pink with a whitish upper lobe and their shape is more like that of $R$. nudiflorum. Mouillefert's two synonyms probably owe their origin to some slip of the pen, for he cites for both "B. M. 3439." 


\section{Rhododendron luteum $\times$ speciosum.}

Azalea nudiflora var. scintillans ${ }^{1}$ Lindley in Bot. Reg. XVII. t. 1461 (1831).

Rhododendron nudiflorum var. scintillans Hooker in Bot. Mag. LXV. t. 3667 (1839).

In the Botanical Register Mr. Gowen says: "This Azalea was raised at Bighclere in the same year with those already figured in previous parts of this work and is a seedling from $A$ zalea coccinea major impregnated by the pollen of Azalea pontica. The flowers are bright pink with the narrow lobes of $R$. nudiflorum and with the upper lobe of a pale buff color or nearly whitish."

The following are probably of the same parentage:

Rhododendron flavum var. ardens Sweet, Brit. Flow. Gard. ser. 2, IV. t. 306 (1835).

Azalea pontica * coronaria $\beta$. ardens De Candolle, Prodr. VII. 718 (1839).

This form was introduced from Holland, according to Sweet, and he says that it "is doubtless a production between $R$. flanum and one of the varieties of $R$. nudiflorum." Judging from its bright scarlet flowers borne in a very large dense head it is near $R$. speciosum and if not simply a form of that species it may very well be a hybrid between it and $R$. luteum.

Rhododendron flanum var. coronarium Sweet, Brit. Flow. Gard. ser. 2, IV. t. 331 (1836).

Azalea pontica * coronaria a. flatum De Candolle, Prodr. VII. 718 (1839).

This is very similar to the preceding except that the flowers are orange-yellow with a red tinge. It also was imported from Holland.

\section{Rhododendron luteum $\times$ viscosum $=$ Rhododendron ornatum Sweet} Brit. Flow. Gard. ser. 2, II. t. 137 (1832).

Azalea pontica-rubescens Gowen ex Sweet, l. c. (1832) as synonym.

Rhododendron viscosum B. ornatum G. Don, Gen. Syst. III. 847 (1834).

Azalea viscosa * ornata De Candolle, Prodr. VII. 617 (1839).

Sweet states that he received the specimen figured the end of May, 1830, and that "the seeds were raised by Lord Carnarvon's gardener from Azalea viscosa $\beta$. rubescens, fertilized by $A$. pontica under Mr. Gowen's own inspection."

Four varieties are distinguished and figured:

a. speciosum, with reddish orange flowers (fig. 1).

$\beta$. incarnatum, with pale pink flowers tipped with white, the upper lobe yellow (fig. 3; in the text by mistake as var. and fig. 2).

$\gamma$. luteum with pale yellow flowers slightly tinged with blush, the upper lobe deep yellow (fig. 2; in the text by mistake as var. 3 and fig. 3 ).

8. roseum with pale rose flowers, the upper lobe with a large orange bloteh (fig. 4).

Rhododendron Mortieri $\times$ luteum (and partly viscosum or arborescens) $=$ Rhododendron gandavense Rehder, comb. nov.

1 This name should not be used for this plant as a binomial designation under Rhododendron, as there is already a $R$. scintillans Balf. f. \& W.W. Sm. 
Azalea Mortieriana Spae in Ann. Soc. Agric. Bot. Gand, II. 325, t. 81 (1846), in part (twelve named varieties are figured).

"Azaleae Mortierianae" Morren in Ann. Soc. Agric. Bot. Gand, 9, t. 106 (1847), in part.

Azalea pontica et var. Witte, Flora, 290, t. 73 (1868).

Azaleae Gandavenses K. Koch, Dendr. II. 185 (1872), as synons.

Azalea Gandavensis Hort. apud K. Koch, Dendr. II. 2, 367 (1873), in the index. - Rehder in Bailey, Cycl. Am. Hort. I. 121 (1900), in part.

This collective group is intended to include all the hybrids between the different species of American Azaleas (exclusive of $R$. occidentale) and $R$. luteum which cannot be traced to any of the binary hybrids but are apparently of more mixed and uncertain parentage. It comprises the garden forms known as Ghent Azaleas or Azalea pontica varieties, also sometimes called Azalea Mortieriana, though Rhododendron Mortieri as first figured and described by Sweet is apparently a binary hybrid between $R$. calendulaceum and $R$. nudiflorum. As it is desirable for practical reasons to have a definite name for this group of hybrids, I have adopted the name gandavense, which has been used in some nursery catalogues in the combination "Azaleae gandavenses" for this group of hybrids. It is one of those cultigen groups which as L. H. Bailey points out (in Science, XLVII. 306 [1918]) need names in the taxonomic treatment of cultivated plants, though such groups cannot be pinned down to a type and are more or less heterogenous and therefore not exactly in accordance with present taxonomic usage.

The following forms seem also to belong here:

"Azaleas de Jardins" Lemaire in Ill. Hort. II. pl. 75 (1855).

Sixteen different named varieties are figured, a flower of each; most of them are similar to the forms of $R$. Morteri, some suggest the influence of $A$. speciosum and some of $R$. luteum.

"Azaleas rustiques de Gand" Van Houtte in Rev. Hort. Belge, III. 3 tab. (1877).

Two named varieties of the $R$. Mortieri type.

"Hardy Azaleas" Osborn in Gard. XV. 318 t. 176 (1879).

Four varieties, probably all representing hybrids of $R$. Morteri.

\section{Rhododendron gandavense var. plenum Rehder, nom. nov.}

Under this name all the double-flowered forms of $R$. gandavense may be classed. I refer here the following forms, of which the first may serve as a type of this group.

Azalea Van Houttei flore pleno Van Houtte in Fl. des Serres, XIII. t. 1298 (1858).

Raised from seed of a form of $R$. Mortieri. The flowers are semidouble with 5 to 10 stamens, and of pink color with the 3 or 4 upper lobes orange.

"Azaleas rustiques de Gand" Van Houtte in Fl. des Serres, XIX. t. 20192024 (1873), excl. t. 2019, 2020.

The plants were bought by Van Houtte from the widow and sons of Louis Hellebuyck, a contemporary of Mortier. Six forms are figured; four of them are double-flowered, two of them (t. 2019 and 2020) are single.

"Hardy double Azaleas" Moore in Flor. \& Pomol. 1880, 89. t. 516. 
Three forms are figured: "Narcissiflora," "Graf von Meran " and "Sappho." The two first named are in cultivation at the Arnold Arboretum. Of the form "Narcissiflora" $R$. luteum seems to be the dominant parent, while Graf von Mersn, though similar, shows in its color and the less glandular pubescence the influence of $R$. nudiflorum.

Rhododendron molle $\times$ occidentale $=\mathbf{R}$. albicans Waterer apud Zabel in Mitteil. Deutsch. Dendr. Ges. XI. 30 (1902). - For further citations see page 97 .

The following references may be added to those given on pages 97 and 98.

Azalea "Waterer's New Hardy" Moore in Flor. \& Pomol. 1883, 177, t. in part.

Three forms are figured, stated to have been raised by Anthony Waterer by crossing A. occidentalis with various hybrids. Two of them, "C. S. Sargent" with yellow flowers and "Henrietta Sargent" with bright rose-colored flowers, are probably hybrids with $R$. Kosterianum forms and may be referred to $R$. albicans, while "Rubra plena" is probably a hybrid of $R$. occidentale with one of the doubleflowered $R$. gandavense and does not belong here.

"New Hybrid Azaleas" W. G. in Gard. XXIX. 550, t. 548 (1886), in part.

Two unnamed varieties are figured of which the white-flowered one apparently belongs here.

Azalea albicans [Waterer] apud Gard. XLV. 229, 322 (1894); apud Jour. Roy. Hort. Soc. XVII. XLVI (1895).

Described as a hybrid between Azalea mollis and $A$. occidentalis with white flowers just touched with yellow and with an orange suffusion on the upper lobes.

I am in favor of restricting the name $R$. albicans to the hybrid forms between $R$. molle (including perhaps $\times R$. Kosterianum) and $R$. occidentale, for which it was originally intended, and to refer the last reference given on page 98 to $R$. mixtum. Of the varieties cited by Wilson, "Graciosa" and "Exquisite" belong certainly to $R$. albicans, of the other two I am not sure. The forms of $R$. albicans are characterized by large light-colored flowers with rather short tube, puberulous and scarcely glandular outside and with the orange blotch consisting of more or less separate dots and with not or slightly exserted stamens; from $R$. molle and $R$. Kosterianum they differ chiefly in the longer, more cylindric tube and the generally pinkish white color of the flowers.

\section{Rhododendron gandavense $\times$ occidentale.}

Azalea "Waterer's New Hardy" Moore in Flor. \& Pomol. 1883, 177, t.; as to var. "Rubra plena."

"New Hybrid Azaleas" W. G. in Gard. XXIX. 550, t. 548 (1886), as to the red-flowered variety.

To this group I am inclined to refer such forms as "Emelie" and "Roi des Belges." They are rather difficult to distinguish from the forms of $\boldsymbol{R}$. gandavense, but may be recognized by the larger flowers with broad open limb, the comparatively short tube, the many-flowered dense inflorescence.

\section{Rhododendron occidentale $\times$ (arborescens $\times$ japonicum).}

Aralea occidentalis $\times$ arborescens $\times$ mollis Rehnelt in Gartenwelt, XX. 8, t. (1916). 
The two varieties figured, one with white flowers flushed pink (Verna Berger) and one with deeper pink flowers (Schöne von Giessen), were raised from seed of $\boldsymbol{R}$. occidentale, the other parent not being stated in the text, but on the plate the hybrid is called Azalea occidentale $\times$ arborescens $\times$ mollis. I have not seen any of these forms.

\section{Rhododendron calendulaceum $\times$ occidentale.}

A hybrid between these two species has been raised at the Arnold Arboretum by W. H. Judd in 1915, and one plant flowered in 1920 for the first time, bearing only a single inflorescence with white flowers suffused with pink and marked with a large orange blotch on the upper lobe.

\section{Rhododendron arborescens $\times$ calendulaceum $=\mathbf{R}$. Anneliesae} Rehder, hybr. nov.

Rhododendron arborescens $\times$ calendulaceum Zabel in Beissner, Schelle \& Zabel, Handb. Laubholz-Ben. 380 (1903), name only.

This hybrid originated accidentally at the Arnold Arboretum and was raised probably in 1896 from seed of $R$. calendulaceum or $R$. arborescens collected in the Arboretum. It is exactly intermediate between $R$. calendulaceum and $R$. arborescens and I have little doubt that it is a hybrid between these two species. The first flowers of $R$. arborescens are usually just beginning to open about the middle of June when late blooming forms of $R$. calendulaceum bear the last flowers; and with dichogamous plants this is just a favorable condition for cross-fertilization. From $\boldsymbol{R}$. calendulaceum it differs chiefly in the glaucous and glabrous under side of the leaves, only the midrib being furnished with strigose hairs and slightly pubescent toward the base, in the very sparingly hairy branchlets and in the longer corollatube of the pinkish white fragrant flowers marked with a large yellow blotch and in the style puberulous only near the base. From $R$. arborescens it differs in the slightly pilose and slightly puberulous branchlets, glabrescent toward the base, in the pubescent and strigose midrib of the under side of the leaves, in the large yellow blotch on the upper lobe of the pinkish white flowers, in the shorter ovate calyx-lobes and in the style being puberulous near the base.

It is a shrub of vigorous habit, very handsome in flower with its large fragrant, pinkish white flowers marked with a conspicuous yellow blotch; the pinkish corollatube is rather densely furnished with short glandular hairs and the style is purple toward the apex. The leaves are elliptic or broadly elliptic and somewhat bluish green above.

This hybrid is named for my wife.

\section{Rhododendron speciosum $\times$ molle.}

Azalea marginata Paxton in Paxton's Mag. Bot. II. 121, t. (1835).

Azalea sinensis coccinea Cunningham Msc. ex Paxton, l. c. (1836), as synon.

The plant is stated to be "a hybrid produced from $A$. coccinea fertilized with the pollen of $A$. sinensis. The size of the flowers and the foliage with the entire habit of the plant is quite like that of the $A$. sinensis with the exception of the color which differs only in the light orange-red margin of the corolla." The hybrid was raised by $\mathrm{Mr}$. Cunningham of Comely Bank near Edinburgh, in whose collection it flowered February, 1835. The parentage given is probably correct as far as can be judged from the colored plate. 


\section{Rhododendron calendulaceum $\times$ viscosum.}

Such a cross is mentioned by Herbert (A maryll. 360) in 1837: "I have raised seedlings from Azalea Pontica-viscosa var. alba and Calendulacen-viscosa var. rubescens." Nothing more, however, seems to have been published about the latter cross; $R$. luteum $\times$ viscosum, see on page 178 .

\section{Rhododendron molle $\times$ viscosum $=$ Rhododendron viscosepalum} Rehder, comb. nov.

Azalea viscosepala R. A. in Gard. Chron. II. 348 (1842).

Azalea viscocephala Arb. Kew. in Herb. Arnold Arb.

In Gardener's Chronicle ( $l$. c.) this is stated to have been raised by $\mathbf{M r}$. Waterer at Knap Hill and is described as "Azalea viscosepala, white with yellow throat. This is a cross between viscosa and Indica alba which latter it very much resembles in foliage."

I have before me specimens collected at $\mathrm{Kew}$ in 1880 as Azalea viscocephala and specimens from plants growing at the Arnold Arboretum which probably represent the same plant. They appear to be intermediate between $R$. viscosum var. glaucum and $R$. molle. From $R$. inscosum they differ chiefly in the earlier larger flowers with a yellow blotch, slightly yellowish in bud, with a stouter tube more dilated above the middle, in the shorter stamens not or slightly exceeding the lobes, in the more densely puberulous tube, in the tomentulose pedicels and calyx and in the thinly pubescent under side of the leaves. From $R$. molle they differ in the fragrant white flowers with a longer, more cylindric tube glandularpilose outside, in the glandular-pilose pedicels and in the smaller and broader usually elliptic leaves glaucous beneath and only slightly pubescent. There is not the slightest trace of Azalea indica alba, which is $R$. mucronatum, in the plant.

\section{Rhododendron viscosepalum var. Daviesii Rehder, comb. nov.}

\section{Azalea Daviesii R. D. in Gard. Chron. ser. 2, XII. 200 (1879). ${ }^{1}$}

Azalea hybrida Daviesii Hort. apud Brettschneider in Gartenfl. XLII. 65, t. 1387 (1893).

This form differs from $R$. viscosepalum chiefly in the larger flowers with a more conspicuous yellow blotch and with a shorter, wider tube. The leaves are almost identical in shape, color and pubescence.

This hybrid was raised by Isaac Davies of Brook Lane Nursery, Ormskirk, and is stated to have been "produced from $A$. sinensis crossed with a hardy white Azalea" and the flowers are described as pale sulphur yellow, changing to white immediately they are fully expanded, and deliciously sweet-scented. A form "Avalanche" is mentioned, produced from the same cross and similar but with pure white smaller flowers. This must be very similar to $A$. viscosepala.

Very similar to var. Daviesii are the following forms:

Azalea altaclarensis Gowen apud Lindley in Bot. Reg. XXVIII. t. 27 (1842), not Rhododendron altaclarense Lindl.

This handsome hybrid was raised at Highclere by J. R. Gowen, who states that "it was produced by fertilizing the flowers of Azalea sinensis with the pollen

1 Not to be confused with $R$. Daviesii Dean, Floral Mag. n. ser. XX. t. 474 (1881), a hybrid of $R$. javanicum and $R$. retusum. 
of the late flowering variety of Azalea viscosa, called by nurserymen $A$. rubescens major." The flowers are large white, slightly bordered pink, with a faint yellow tinge at the base of the lobes, and with the upper lobe distinctly dotted yellow and the tube pinkish outside. The gradually dilated tube and the yellow tinge and the spotted upper lobe indicate the influence of $R$. sinense and the white color and hirsute tube of the corolla and the delicious fragrance the influence of R. viscosum.

Azalea sinensis alba Van Houtte in Fl. des Serres, XX. 151. t. 2143-44 (1874).

Van Houtte gives no description and no hint of the origin of the plant save the remark that it is far removed from the true $A$. sinensis. It is possibly the same form of which a plant was received by the Arnold Arboretum from Koster and Son in 1904 under the name Azalea chinensis alba grandiflora.

\section{Rhododendron ? gandavensis $\times$ molle.}

Azalea sinensis var. Bylsiana Morren in Ann. Soc. Agric. Bot. Gand, I. 278, t. 27 (1845).

This form was raised by the Ghent horticulturist Byls from seeds of $A$. sinensis. It is apparently a hybrid and has large white flowers edged pink and the upper lobe with a large yellow blotch. This is not to be confused with $R$. Bylsianum Henderson, $\mathrm{Ill}$. Bouquet, I. t. 18 (1857-59), a hybrid form of Eurhododendron.

Azalea sinensis var. macrantha Spae in Ann. Soc. Agric. Bot. Gand, III. 127, t. 122 (1847).

This form is of the same origin as the preceding; its flowers are white tinged with pale rose and marked with a large yellow blotch dotted orange. As a similar form is mentioned $A$. sinensis var. versicolor raised by Buyck-Vander Meersch.

\section{Rhododendron japonicum $\times$ nudiflorum.}

Azalea nudiflora $\times$ sinensis Van Fleet in U. S. Dept. Agric. Bur. Pl. Indust. CCXXIII. 17 (1911).

"Vigorous hybrids with profuse cream, rose and salmon colored blooms," raised by Dr. W. Van Fleet at Little Silver, N. J., and presented to the Plant Introduction Garden in Chico, California, in 1910. The parent species called Azalea sinensis is probably $R$. japonicum, for the former is not known to have been in cultivation in this country before 1910 except young seedlings at the Arnold Arboretum, raised in 1908.

Rhododendron japonicum $\times$ molle $=$ Rhododendron Kosterianum Schneid. See page 97.

\section{Rhododendron gandavense $\times$ Kosterianum $=$ Rhododendron mix-} tum Wilson. See page 98.

Azalea rustica flore-pleno Vandevoorde in Rev. Hort. Belge, XIX. 232 t. (1893). Azalea mollis fl. pleno "Virgil" Reiter in Gartenwelt, XV. 493, fig. (1911), habit figure.

Rhododendron occidentale $\times$ molle $\times$ "Ghent Azaleas" Millais, Rhodod. 220, fig. (habit) (1917). 
Three forms are represented in the colored plate with pink, yellow and orange flowers. They are called double-flowered $A$. mollis, but are probably hybrids of $\boldsymbol{R}$. gandavense and $R$. Kosterianum. I have seen neither plants nor specimens of these double-flowered forms.

Wilson has based the name $R$. mixtum on the double-flowered Azalea rustica flore-pleno, but we may include under this name all the different forms probably of the same parentage as given by Wilson. 


\section{SECT. PENTANTHERA $\times$ RHODORA}

\section{Rhododendron canadense $\times$ luteum $=$ Rhododendron Seymouri}

Herbert ex Lindley in Bot. Reg. XXIII. t. 1975 (1837), as synon. De Candolle, Prodr. VII. 728 (1839).

Azalea Seymouri Lindley in Bot. Reg. XXIII. t. 1975 (1837).

Rhododendron flavum ı. Seymourii Sweet, Hort. Brit. ed. 3, 442 (1839).

This is a very interesting hybrid, being the first raised between species of the sections Pentanthera and Rhodora. It is clearly intermediate between $R$. canadense and $\boldsymbol{R}$. luteum; the flowers are small, of a pale yellow color with a faint tinge of pink and appear with the leaves; the stamens are shorter than the corolla-lobes and 7 to 9 in number. According to Herbert "A great number of plants were raised at Spofforth from Rhodora Canadensis impregnated with the pollen of Azalea Pontica. Their constitution seemed ticklish or the peat in which they were grown disagreed with them and only one plant was preserved, which formed a healthy low bush, more spreading than Rhodora."

Rhododendron Seymouri is apparently no longer in cultivation. It was not a showy plant with its small pale yellow flowers and thus the chief incentive to propagate it was lacking. There is, however, no reason why among seedlings of this cross should not appear plants with the color of $R$. canadense, and those certainly would be much handsomer and more like the following hybrid.

\section{Rhododendron canadense $\times$ japonicum $=$ Rhododendron Fraseri} W. Watson in Gard. Chron. ser. 3, LXVII. 225 (1920). - See also page 103.

This interesting and handsome hybrid was raised by Mr. G. Fraser of Ucluelet, Vancouver Island, B. C., by crossing $R$. canadense with $R$. japonicum in 1912. The young plants flowered for the first time in 1919 and the same year Mr. Fraser kindly sent a living plant to the Arnold Arboretum which flowered in the spring of 1920. On account of the earliness of its profusely produced, rosy mauve flowers much larger than those of Rhodora the new hybrid will have a decided ornamental value and will also be useful for forcing. To supplement the short description in the Gardeners' Chronicle ( $l$. c.) a fuller description may be given here.

Low shrub of slender twiggy habit; young branchlets finely pubescent and strigose, yellow-brown and glabrous the second year; winter-buds, consisting of 10 to 12, finely pubescent, ovate and mucronulate scales. Leaves elliptic-oblong to oblong, acute and gland-tipped at apex, cuneate at base, 4 to $6 \mathrm{~cm}$. long and about $2 \mathrm{~cm}$. broad, ciliate, bright green, sparingly and finely villose and strigillose above, lighter green or sometimes glaucescent beneath and short-villose, strigillose on the midrib and veins, rather thin and often only slightly villose at maturity, with 10 to 12 pairs of veins prominent beneath and yellowish; pedicels slender, 5 to $8 \mathrm{~mm}$. long, slightly villose and strigose while young. Flowers scentless, in dense 8- to 15 -flowered clusters; pedicels 1 to $1.5 \mathrm{~cm}$. long, finely pubescent and glandular-pilose; sepals unequal, ovate, 1 to $2 \mathrm{~cm}$. long, ciliate with long setose eglandular 
hairs; corolla deeply two-lipped, rosy-lilac, the upper lip spotted, slightly villose and short-pilose and sparingly glandular outside, tube funnel-form, 6 to $8 \mathrm{~mm}$. long, sparingly pubescent inside, the two lower lobes separated nearly to the base of the limb, oblong, 2 to $2.5 \mathrm{~cm}$. long and 1 to $1.2 \mathrm{~cm}$. broad, obtuse or obtusish, upper lip as long and about $3 \mathrm{~cm}$. broad, divided to about the middle into 3 ovate lobes; stamens 10, unequal, the longer about two thirds as long as corolla; the filaments pilose on the lower fourth; the anthers about $1 \mathrm{~mm}$. long; style finely pilose at base, with green stigma; ovary setosely pilose, eglandular. 


\section{SECT. TSUTSUTSI}

Rhododendron $?$ indicum $\times$ linearifolium $=$ Rhododendron Eeckhautei Rehder in Bailey, Stand. Cycl. Hort. V. 2945 (1916).

Azalea Eeckhautei Pynaert in Rev. Hort. Belge, XXXVII. 117, t. (1911).

This very distinct hybrid was raised by Eeckhaute of St. Denis Westrem, Belgium, from "Azalea linearifolia fécondé par l'A. indica var. Souvenir du Recteur Kickx." The shape of the corolla and of the leaves is similar to that of the mother plant, but the flowers are larger and bright rose-colored.

\section{Rhododendron Simsii $\times$ obtusum $=$ Rhododendron Sanderi Wil-} son. See page 43.

There are probably other hybrids in this section as $e . g . R$. phoeniceum (see page 61) which according to Wilson is possibly a hybrid between $R$. mucronatum G. Don and $R$. scabrum G. Don; and some of the varieties cultivated as Indian Azaleas are in all probability hybrids between $R$. indicum and $R$. Simsii (see page 25). Rhododendron pulchrum Sweet, which is considered by Sweet a hybrid between $R$. indicum and $R$. ledifolium (= mucronatum), is according to Wilson probably a form of $\boldsymbol{R}$, phoeniceum (see page 62). 


\section{SUBGEN. ANTHODENDRON $\times$ EURHODODENDRON}

\section{SECT. PENTANTHERA $\times$ LEIORHODION}

Rhododendro-Azalea Herbert, Amaryllid. 360 (1837).

Azaleodendron Rodigas in Ill. Hort. XXXIX. 53 (1892), - Masters in Gard. Chron. ser. 3, XIII. 665 (1893). - André in Ret. Hort. 1893, 369.

Rhodazalea Croux \& fils in Jour. Soc. Hort. France, sér. 4, IX. 328 (1908). Gérôme in Jardin, XXIV. 279 (1910).

The first hybrid known to have been raised in the genus Rhododendron is one between species of the two subgenera Anthodendron and Eurhododendron, which originated before 1800 in Thompson's Nursery at Mile End near London. Later other hybrids of eimilar origin were raised at Highclere in the gardens of the Earl of Carnarvon, by William Herbert at Spofforth, by Wm. Smith at Norbiton, who is particularly known for forms with yellow flowers produced by crossing $R$. molle with various evergreen Rhododendrons, by Isaac Davies of Brook Lane Nursery, Ormskirk, and others. Another race consisting of the hybrids between evergreen Rhododendrons and $\boldsymbol{R}$. japonicum was raised by Vander Meulen of Ghent about 1890 and more recently by Croux \& fils, Val d'Aulnay, at Châteney (Seine).

By those who keep Azalea and Rhododendron distinct new generic names have been coined. The oldest of them is Rhododendro-Azalea of Herbert, mentioned only incidentally by the author and not formally proposed. The second was proposed by Rodigas for the hybrids between $R$. japonicum and evergreen Rhododendrons. The third name was given for hybrids of similar origin, but Rhodazalea Crouxii, the type of this group, has only five stamens and thus differs from Azaleodendron which has ten stamens.

Rhododendron ? nudiflorum $\times$ ponticum $=$ Rhododendron azaleoides Hort. Lond. apud Dumont de Courset, Bot. Cult. III. 327 (1811); VII. 165 (1814). - Desfontaines, Tabl. Jard. Paris, 272 (1815), as $R$. azaloides, name only.

Rhododendron ponticum var. deciduum Andrews, Bot. Rep. VI. t. 379 (1801).

Rhododendron ponticum $\beta$. subdeciduum "A. R." apud Sweet, Hort. Brit. 264 (1826).

Rhododendron ponticum b. azaleoides Loudon, Arb. Brit. II. 1131 (1838). De Candolle, Prodr. VII. 722 (1839).

Rhododendron azaleoides inodorum André, Pl. Terre Bruy. 162 (1864).

According to Andrews this hybrid originated in Thompson's Nursery at Mile End near London and its supposed mother plant is Rhododendron ponticum fertilized by some Azalea. The leaves are rather large, oblong and acuminate, and the corolla is pale purple, not spotted or blotched, with the corolla-lobes very wavy at the margin; the stamens have purple anthers. It is likely that a form of $R$. nudiflorum is the male parent, as there is no indication of $R$. viscosum in the hybrid and these two species are the only Azaleas well known before 1800 . The plant described by Dumont de Courset seems very similar, the flowers are about the same color and nothing is said about fragrance, while the plants described and figured by later authors as $R$. azaleoides differ in their usually white or nearly white very fragrant flowers and are apparently of different origin. The R. azaleoides of Sprengel (Neu 
Entdeck. II. 130 [1821]) is different from both, as he describes his plant as with obtusish leaves pubescent on both sides, and it is doubtful if it belongs here at all. Whether Hoffmannsegg's $R$. azaleoides (Verzeichn. 1826, 194) belongs here, I am unable to say, as I have no access to that publication. Similar to $R$. azaleoides are the following:

Rhododendron gemmiferum Hort. apud Zabel in Beissner, Schelle \& Zabel, Handb. Laubholz-Ben. 379 (1903), name only. - Bean, Trees \& Shrubs Brit. 1sl. II. 358 (1914). - Rehder in Bailey, Hand. Cycl. Hort. V. 2946 (1916). - Millais, Rhodod. $172(1917)$.

Bean does not say anything about its parentage, but according to a plant cultivated at the Arnold Arboretum it seems to be little different from Andrew's plant except that it has broader obtusish or acutish leaves slightly pubescent beneath and when very young also above; the flowers are nearly glabrous outside. A cross between $R$. roseum and $R$. catawbiense might produce a similar offspring.

Rhododendron Gowenianum Sweet, Brit. Flow. Gard. III. t. 263 (1828). - De Candolle, Prodr. VII. 728 (1839). - Bean, Trees \& Shrubs Brit. Isl. II. 344 (1914).

Rhododendron nudiflorum 0 . Govenianum G. Don, Gen. Syst. III. 847 (1834).

Rhododendron nudiflorum $\times$ (catawbiense $\times$ ponticum) ex Sweet, $l$. $c$.

This hybrid was raised in the collection of the Earl of Carnarvon at Highelere by J. R. Gowen from seed of " $A$. nudiflora or viscosa . . . fertilized with the pollen of a hybrid Rhododendron between $R$. ponticum and $R$. catawbiense." The leaves are evergreen or scarcely deciduous, elliptic-oblong to lanceolate-oblong, pubescent on both sides when young, glabrous above and glossy when old. The flowers are light purple, rather small, with a comparatively long and narrow tube. From the illustration it is impossible to judge whether $R$. nudiflorum or $R$. viscosum is one of the parents; G. Don calls it a hybrid of $R$. nudiflorum and makes it a variety of that species, but Bean says that it is very near his $R$. azaleoides which is referred here to $R$. hybridum.

Rhododendron Cartonianum De Candolle, Prodr. VII. 727 (1839).

"Carton's Rhododendron" Lindley in Bot. Reg. XVII. t. 1449 (1831).

Rhododendron nudiflorum $\psi \psi$. Cartoni Sweet, Hort. Brit. ed. 3, 442 (1839).

Rhododendron Cartoni Bean, Trees \& Shrubs Brit. Isl. II. 344 (1914).

Rhododendron nudiflorum $\times$ catawbiense ex Lindley, $l$. $c$.

According to Gowen "ninety-seven plants were raised in the Highclere Garden, in the year 1825, from a specimen of Azalea nudiflora purposely touched with pollen of Rhododendron Catawbiense. They vary in habit in the size of the umbel and in the deeper or fainter purple tint of the corolla." Lindley named the plant figured "the finest of the above set of hybrids in compliment to the Gardener of the Earl of Caernarvon, Mr. James Carton."

The plant is very similar to that figured by Sweet as $R$. Gowenianum except that the flowers are more white inside at the base of the limb.

Rhododendron viscosum $\times$ maximum $=$ Rhododendron hybridum Ker in Bot. Reg. III. t. 195 (1817). ${ }^{1}$

Rhododendron hybridum glaucum Herbert ex Sims in Bot. Mag. XLIX. sub t. 2308 (1822), incidental mention.

Rhododendron bigener Hort. ex Steudel, Nomencl. ed. 2, II. 450 (1841).

1 "Rhododendron hybridum Franch. - Yunnan" enumerated by Vilmorin \& Bois, Frut. Vilmor. 175 (1904), is probably a mistake. I have been unable to find any reference to such a name elsewhere. 
Rhododendron ponticum azaleoides 2. odoratum Loudon, Arb. Brit. II. 1131 (1838).

Rhododendron odoratum Loddiges apud Steudel, Nomencl. ed. 2, II. 450 (1841).'

Rhododendron azaleoides odoratum André, Pl. Terr. Bruy. 162 (1864).

A zalea odorata Hort. apud Goldring in Gard. Chron. ser. 3, VIII. 25 (1890). H. P. \& W. G. in Gard. XL. 34 (1891).

Rhododendron fragrans in Jour. Hort. ser. 3, XLIX. 489, fig. (1904)? not Paxton.

Rhododendron azaleoides Bean, Trees \& Shrubs Brit. Isl. II. 344 (1914), not Dumont de Courset.

As stated by Ker this hybrid was "raised by Mr. Herbert at Spofforth near Weatherby, from seed ripened on the common white glaucous-leaved Azalea in the flower of which the pollen or dust from the anthers of Rhododendron maximum had been purposely substituted for that of its own flower." The evergreen leaves are oblong, acute at both ends and glaucous beneath; the flowers are rather small, whitish, the lobes with a pinkish border and the upper lobe spotted yellow, the tube cylindrical. I am referring to $R$. hybridum, though not without some doubt, the $R$. azaleoides as described by $\mathrm{Mr}$. Bean, which according to his opinion possibly is a hybrid of $\boldsymbol{R}$. viscosum and $\boldsymbol{R}$. maximum and Mr. Bean's judgment can be depended upon. Also a specimen I collected nearly twenty years ago at Kew as $\boldsymbol{R}$. odoratum agrees much better with Ker's figure than with that of $\boldsymbol{R}$. fragrans Paxton, though the corolla-tube is not so cylindrical as represented in that figure.

\section{Rhododendron viscosum $\times$ ponticum $=$ Rhododendron enneandrum} De Candolle, Prodr. VII. 728 (1839).

Azalea hybrida enneandra Sims in Bot. Mag. XLLX. t. 2308 (1822).

Rhododendron hybridum enneandrum Herbert in Trans. Hort. Soc. III. ex Sims, l. $c$.

Rhododendron azaleoides Reider in Ann. Blumist. V. 84 (1829); VII. t. 11 (1831), the plate bearing the name $R$. azaleoides alba odorata.

Sims states that this is a hybrid raised by Wm. Herbert from seed of a whiteflowered Azalea fertilized with the pollen of $R$. ponticum; the flowers are very fragrant, rather small, funnel-form, white, slightly tinged lilac, the upper lobe dotted green. Reider's $R$. azaleoides may belong here though the upper lobe is not dotted green.

Rhododendron viscosum $\times$ ? catawbiense $=$ Rhododendron fragrans Paxton in Paxton's Bot. Mag. X. 147, t. (1843). ${ }^{2}$

1 A specimen collected by me at Kew Gardens in 1901 as $R$. odoratum apparently belongs here and certainly is the hybrid described by Bean as $R$. azaleoides, while another specimen in the herbarium of the Arnold Arboretum collected by H. Zabel in the Botanic Garden at Muenden, Hanover, from a plant received in 1882 as $\boldsymbol{R}$. odoratum from T. Smith in Bergedorf near Hamburg, is not the same and similar to $R$. azaleoides.

${ }^{2}$ As $R$. fragrans Paxton must be considered a duly published name, it invalidates $R$. fragrans Maximowicz of 1870 , for which I propose the following new name:

Rhododendron Adamsii Rehder, nom. nov.

Azalea fragrans Adams in Mém. Acad. Sci. St.-Pétersb. II. 332, t. 14 (1808).

Azalea pallida Turczaninow in Bull. Soc. Nat. Mosc. 1838, 96 (1838), name only. 
Paxton observed this hybrid in the nursery of Chandler \& Sons, Vauxhall, and states that it was "raised accidentally from seed of a variety of $R$. catawbiense twenty-five or thirty years ago." He describes it as "a very compact dwarf shrub, decidedly evergreen with small and dense foliage and numerous clusters of pretty pale pinkish lilac blossoms in which there is a variety of delicate tints approaching to white in the center. It has quite the habit of a Rhododendron and looks like a small close-growing, pale-flowered variety of $R$. ponticum." Herbert had apparently this hybrid in mind when he says (A maryll. 360): "The fragrance of the Azaleas has been communicated to the Rhododendrons both by the Mitcham crosses and that of Mr. Chandler." To the Mitcham crosses, however, I have found no other references.

Here may belong:

Rhododendron elegantissimum Davies apud R. D. in Gard. Chron. ser. 2, XII. 200 (1879).

"Early White Azalea" $\times R$. Hendersonii R. D., l. $c$.

This is said to have white flowers tipped with deep lilac and of agreeable fragrance. I assume that under Early White Azalea an early flowering form of $R$. viscosum is understood, as the flowers are very fragrant and $R$. Hendersonii, a name for which I can find no other reference except Millais, Rhodod. 38, and which is possibly one of the $R$. catawbiense hybrids.

Rhododendron roseum odoratum Davies apud R. D. in Gard. Chron. ser. 2, XII. 200 (1879). - Vilmorin \& Bois, Frut. Vilmor. 175 (1904).

"Early White Azalea" $\times R$. Brayanum R. D., l. c.

This is described as similar to the preceding, but with rose-colored flowers. Rhododendron Brayanum is mentioned by Millais, Rhodod. 35.

\section{Rhododendron ? calendulaceum $\times$ ? catawbiense.}

Rhododendron ponticum var. azaleoides Torloniana Morren in Ann. Soc. Agric. Bot. Gand, I. 21, t. 4 (1845).

? Rhododendron Tolerianum hort. apud Zabel in Beissner, Schelle \& Zabel, Handb. Laubhola-Ben. 379 (1903), name only.

Nothing is said of the origin or parentage of this hybrid form. The flowers much resemble in size, shape and color the plant figured by Guimpel as R. azaleoides mentioned below, but the upper lobe shows a large orange blotch while Guimpel's figure does not show the slightest trace of orange or yellow; this and the shape of the corolla seem to indicate the influence of $R$. calendulaceum.

I am not aware that this plant is at present in cultivation, though it is certainly one of the handsomest of this group of hybrids.

Rhododendron azaleoides Guimpel, Otto \& Hayne, Abb. Fremd. Holzgero. 15, t. 15 (1825), not Dumont de Courset.

Osmothamnus fragrans De Candolle, Prodr. VII. 715 (1839).

Osmothamnus pallidus De Candolle, $l$. c. (1839).

Rhododendron fragrans Maximowicz in Mém. Acad. Sci. St.-Pétersb. XVI. No. 9, 16 (1870).

Rhododendron pallidum Dümmer in Gard. Chron. ser. 3, LIII. 264 (April 26, 1913), not $R$. pallidum W. Watson in Gard. Chron. l. c. 230 (April 12, 1913).

Diimmer seems to consider Azalea pallida Turcz. as specifically distinct, but even if we unite it with Azalea fragrans the combination $R$. pallidum cannot be used in place of $R$. fragrans, as it is antedated by W. Watson's name which, though insufficiently described, should stand as the name of the hybrid for which he intended it. (See also C. P. Raffil's remarks in Gard. Chron. l. c. 332.) 
If the colored plate is a true representative of the plant it is certainly, with the form just mentioned, one of the handsomest of this group of hybrids on account of its large flowers and the pure pink color without any trace of the lilac or purple found in most related forms. The leaves are almost acuminate, to $8 \mathrm{~cm}$. long and green on both sides; the flowers are broadly funnelform-campanulate, about $6 \mathrm{~cm}$. wide, with broad lobes wavy at the margin, white and more or less tinged and striped pink. Nothing is said of the origin of the plant, but it was apparently English.

The following is a hybrid probably of similar origin :

Azalea (var.) magnifica (Rollisson's) Van Houtte in Fl. des Serr. XIII, 31, t. 1306-7 (1858). - Lemaire in Ill. Hort. VI. t. 209 (1859).

Nothing is said about the origin of this plant except that it was received from W. Rollisson. According to the plate it is a very handsome plant with large white flowers slightly tinged pink, the upper lobe with a large orange bloteh and the other lobes marked with pink veins near the margin; the number of stamens is 6 to 8 .

\section{Rhododendron gandarense $x$ ? catawbiense.}

Rhododendron "Deception" Standish and Noble in Jour. R. Hort. Soc. V. 274 (1850). - Burbidge, Cult. Pl. 298 (1876).

Described as having pink spotted flowers and fine foliage and stated to be a hybrid between a "large yellow Ghent Azalea and $R$. catawbriense."

Rhododendron discolor $\times$ occidentale Bean in Rhodod. Soc. Notes, I. 191 (1919), name only.

Flowers not yet known.

Rhododendron luteum $\times$ ponticum $=$ Rhododendron Laetitiae Herbert apud Lindley in Bot. Reg. XXXI. t. 51 (1845).

This hybrid was raised by W. Herbert of Spofforth from seed of Rhododendron ponticum fertilized by Azalea pontica. The leaves are described as "rather more durable, broader and blunter than the leaves of Azalea Pontica"; the flowers are large, white and fragrant, the three upper lobes with large orange blotches and smaller dots. The plant is named after Mrs. W. Herbert. This is apparently one of the seedlings mentioned in 1837 by Herbert in his Amaryllidaceae, page 359: "Four evergreen seedlings obtained from the seed of Rhododendron Ponticum which I had fertilized with pollen of Azalea Pontica have flowered at Highclere."

Of similar origin ("Azalea pontica $\times$ evergreen Rhododendron") were the hybrids raised by Adam of Altenburg, and offered to the trade by Rinz of Frankfort, Germany, probably about 1850; eleven varieties are enumerated by André (Pl. Terre Bruy. 164 [1864]).

\section{Rhododendron speciosum $\times$ arboreum.}

Rhododendron nudiflorum var. eximium Sweet, Brit. Flow. Gard. ser. 2, III. t. 291 (1835).

Rhododendron eximium D. Don apud Zabel in Beissner, Schelle \& Zabel, Handb. Laubholz-Ben. 379 (1903), not Nuttall. 
This hybrid was raised by William Smith of Norbiton Common, near Kingston, "in 1829 from seeds of the variety coccinea major of Rhododendron nudiflorum that had been fertilized by arboreum." This handsome hybrid has evergreen, thin, oblong-lanceolate leaves, pubescent beneath and crimson flowers with a rather long tube finely pubescent outside and with the upper lobe dotted dark purple. The varietal name cannot be used for a binomial combination on account of $R$. eximium Nutt. of 1853.

\section{Rhododendron molle $\times$ arboreum.}

Rhododendron carneum elegantissimum Lemaire in $F l$. des Serres, II. pt. 3, t. 3 (1846).

Lemaire states that this is one of the hybrids obtained by William Smith of Norbiton and that it was raised from seed of $R$. arboreum fertilized by Azalea sinensis. It has exactly the habit of $R$. Smithii aureum, but the flowers are pale pink or lilac, whitish toward the center and the upper lip conspicuously dotted. The name elegantissimum cannot be used for a binomial on account of $R$. elegantissimum Davies (see page 191).

Rhododendron molle $\times$ (maximum $\times$ ponticum $)=$ Rhododendron norbitonense Smith apud André, Pl. Terre Bruy. 166 (1864); in Rev. Hort. $1893,370$.

"Norbiton hybrids" Hort. ex Masters in Gard. Chron. ser. 3, XIII. 665 (1893).

Rhododendron sinense $\times$ Eurhodendron spec. Zabel in Beissner, Schelle \& Zabel, Handb. Laubholz-Ben. 379 (1903).

This interesting and handsome race of hybrids was raised by Wm. Smith of Norbiton near Kingston, England, about 1830. After they had been exhibited in Ghent in 1839 and before the Horticultural Society in London in 1842, they attracted much attention as yellow-flowered Rhododendrons and became widely known. Of their parentage Lindley (in Bot. Reg. XXXI. sub t. 51 [1845]) says: "The yellow and coppery mules of the late Mr. Smith of Norbiton were obtained from that white Rhododendron ["the fine white cross between $R$. ponticum and maximum"] by the pollen of sinense." Smith apparently raised a large number of different forms; fifteen of them are enumerated by Henderson in his Illustrated Bouquet, t. 46 (1859-61), and by Millais, Rhodod. 26 (1917), and others by André, Pl. Terre Bruy. 166 (1864), one of them being "Victoria regina" mentioned on page 99 of this work. Of these many forms only the two following seem to be well known to-day.

Rhododendron norbitonense var. aureum Rehder, comb. nov.

Rhododendron Smithii aureum Paxton, Mag. Bot. IX. 79, t. and fig. (1842). Lemaire in $F l$. des Serres, I. 45, t. (1845). - For further literature and synonyms, see page 98 .

This variety differs from the typical form, which has orange-yellow flowers, in its golden yellow flowers. It is still in cultivation and well known as $R$. Smithii aureum, but as there is a $R$. Smithii Nutt. which is an entirely different Himalayan species, and also a $R$. Smithii Sweet which is $R$. arboreum $\times$ ponticum, this name 
should be discarded, as it is not only against all rules of nomenclature but also misleading and confusing.

Rhododendron norbitonense var. broughtonianum Rehder, comb. nov.

Rhododendron broughtomianum André, Pl. Terr. Bruy. 166 (1864); in Rev. Hort. $1893,370$.

Rhododendron broughtonii aureum Hort. apud W. Watson, Rhodod. \& Azaleas, 93 (1911). - For further literature and remarks, see page 99.

I have little doubt that $R$. broughtonianum and $R$. broughtonii aureum are identical, and though the plant is well known under the latter name, its use should be discontinued, as it is, like $R$. Smithii aureum, both incorrect and misleading, since there is already a $R$. broughtonii Hort. which is a hybrid between two species or forms of Eurhododendron with rosy-red flowers; moreover, the name broughtonii suggests the proper name of a person and not of a place. A good habit picture is given by Millais in his Rhododendrons (pl. opposite page 184).

Other forms of similar parentage were raised by Standish and Noble and later by Anthony Waterer and by Mr. White of Sunningdale. The following also belongs here:

Rhododendron Williamsii Millais, Rhodod. 262 (1917).

A hybrid raised by Williams of Holloway about 1885 between a hardy Rhododendron and $R$. sinense.

Rhododendron japonicum $\times$ Eurhododendron "hybrids" = Rhododendron azaleodendron Vilmorin \& Bois, Frut. Vilmor. 175 (1904).

Azaleodendron Rodigas in Ill. Hort. XXXIX. 53 (1893). - (See also page 136). Azaleodendron "Comte de Kerchove," De Bosschere in Rev. Hort. Belge, XIX. 177, t. (1893).

Here belong the hybrids raised by G. Vander Meulen between "A zalea mollis" (=R. japonicum) and R. "Prince Camille de Rohan" and "Leopard." As the type of this group of hybrids "Comte de Kerchove" may be taken; this form is described in detail by Masters (in Gard. Chron. ser. 3, XIII. 667 [1893]) and figured in Gard. Chron. l. c. 663 and also in Rev. Hort. Belge, l. c. (colored pl.), and in Rev. Hort. 1893, 369. Besides "Comte de Kerchove" five other varieties were exhibited at Ghent in 1892 by Pynaert and Van Gaert who acquired the entire stock of Vander Meulen's hybrids; their color ranges between white and rosy-red or rose-lilac with conspicuous dark spots on the upper lobes. According to André (in Rev. Hort. 1893, 371) similar hybrids between "Rhododendron and Azalea mollis" had been shown in Ghent by Ad. Rosseel in 1888.

\section{Rhododendron? Kosterianum $\times$ Eurhododendron hybrids $=$ Rhodo-} dendron Crouxii Rehder, comb. nov.

Rhodazalea Crouxii Croux \& fils in Jour. Soc. Hort. France, sér. 4, IX. 328, fig. (1908). - Gérôme in Jardin, XXIV. 279, fig. 157 (1910).

This hybrid was obtained by Croux \& fils of Val d'Aulnay at Chattenay (Seine), according to their statement, by crossing a Rhododendron with a variety of $A$ zalea mollis, the exact name of neither of the parents being given. The flowers are large, 
their color is Naples yellow tinged with rose, the upper lobes conspicuously spotted. The number of stamens is 5 , which distinguishes this hybrid from the similar R. azaleodendron.

Rhododendron Crouxii f. plenum Rehder, nom. nov.

Rhodazalea Crouxii flore pleno, Croux \& fils in Jour. Soc. Hort. France, sér. 4, IX. 328 (1908). - Gérôme in Jardin, XXIV. 279, fig. 158, 159 (1910). Azalea mollis $\times$ Rhododendron "Marie Van Houtte" Croux \& fils, $l$. $c$.

This form has semi-double yellow flowers tinged with rose. 


\section{SECT. TSUTSUTSI $\times$ LEIORHODION}

The following forms have been supposed to be hybrids between the sections Tsutsutsi and Leiorhodion.

Rhododendron azaleoides var. crispiflorum Lemaire in IU. Hort. V. t. 181 (1858).1

This handsome and interesting hybrid was raised, according to Lemaire, by a Ghent horticulturist, Louis Demotte, by crossing a hybrid Rhododendron with an Indian Azalea, probably the var. "Reymdersiana." Judging from the figure and the characters given in the description this plant seems indeed to be a hybrid of a species or form of the section Tsutsutsi and a form of Eurhododendron, the only one known to me, for the two following forms which are supposed to be hybrids of an Indian Azalea and an evergreen Rhododendron are apparently only forms of R. phoericeum.

Azalea Rawsonii Paxton in Paxton's Flow. Gard. III. 123 t. (1836).

This Azalea was raised by John Menzies, gardener to Christopher Rawson of Hope House near Halifax. In a letter Mr. Menzies "states as his belief that it is produced between $A$. phoenica and Rhododendron dauricum atrovirens." Judging from the colored plate it is a simple form of $R$. phoeniceum. See also pages 61 and 62.

Rhododendron phoeniceum var. splendens Sweet, Brit. Flow. Gard. ser. 2, IV. t. 385 (1837).

This is said to have been "raised by Mr. Wood, gardener to Mrs. May at Sydenham, from a plant of Rhododendron phoeniceum that had been fecundated by $R$. catawbiense." It appears to be only a form of $R$. phoeniceum; not the slightest influence of $R$. catawbiense is noticeable in the plant figured. See also page 63.

1 Not $R$. indicum var. crispiflorum Schneid. - See page 27. 


\section{DOUBTFUL NAMES}

Azalea calendolacea alba bicolor Hort. apud Kirchner in Petzold \& Kirchner, Arb. Musc. 479 (1864).

Described as having white flowers with rose-carmine tube. Probably a form of R. nudiflorum.

Azatien calendolacea astreans Hort, apud Kirchner, l. c. 479 (1864).

Described as having brick-red flowers.

Azalea calendulacea $\beta$. Chrysolecta Sweet, Hort. Brit. 265 (1826), name only.

Rhododendron calendulaceum $\beta$. chrysolectum Sweet, Hort. Brit. ed. 2, 343 (1830), "golden."

azalea calendulacea coccinea fulgens Hort. apud Kirchner, l. c. 479 (1864).

Flowers described as dark brick red.

Azalea calendolacea cristata Hort. apud Kirchner, in Petzold \& Kirschner, Arb. Musc. 479 (1864).

Described with yellowish brick-red flowers.

Azalea calendolacea coprea elegans Hort. apud Kirchner, $l$. c.

Flowers described as rose red, small and very crowded. Possibly a form or hybrid of $R$. nudiflorum.

Azalea calendulacea fenestrata Hort. apud Kirchner in Petzold \& Kirchner, Arb. Musc. 479 (1864).

Flowers described as ponceau-rose, marked yellow and whitish, very handsome. Probably a form of $\times R$. Mortieri.

Azalea calendulacen folgens excelba Hort. apud Kirchner, l. c. 479 (1869). Flowers described as dark orange-red.

Azalea calendolacea $\gamma$. grandiflora Sweet, Hort. Brit. (1826), name.

Rhododendron calendulaceum $\gamma$. grandiflorum, Sweet, $l$. c. ed. 2, 343 (1830), "orange."

Azalea calendulacea $\theta$. ignescens Sweet, Hort. Brit. 265 (1826), name only.

Rhododendron calendulaceum $\theta$. ignescens Sweet, l.c. ed. 2, 343 (1830), "copperyellow."

Azalea calendolacea recurva Hort. apud Kirchner in Petzold \& Kirchner, Arb. Musc. 479 (1864).

Flowers described as fawn-colored, marked pale yellow, very flat, small and crowded. Probably a form of $\times \boldsymbol{R}$. Morteri.

azalea calendtlacea sanguinea Hort. apud Kirchner, l. c. 479 (1864).

Flowers described as similar to var. coccinea fulgens, but darker and more scarlet.

Azalea calendolaces Saturnea Hort. apud Kirchner, l. c. 479 (1864).

Flowers described as bright and deep rose-colored.

Azalea calendulacea e. splendens Sweet, Hort. Brit. 265 (1826).

Rhododendron calendulaceum $\epsilon$. splendens Sweet, l.c. ed. 2, 343 (1830), "copperyellow."

Azalea calendulacen Sterniana Hort. apud Kirchner, in Petzold \& Kirchner, Arb. Musc. 479 (1864).

Flowers described as bright orange, very handsome and large. 
Azamia calendulacea $\eta$. TrRomphans Sweet, l. c. 265 (1826), name.

Rhododendron calendulaceum ᄁ. triumphans Sweet, l. c. 343 (1830), "copperyellow."

Azalea fascicutata Dumont de Courset, Bot. Cult. VII. 166 (1814).

Azalea fastigiata Dumont de Courset, l. c. (1814).

Described as having the flowers fascicled in a kind of an umbel. Probably the same as Azalea nudiflora $\lambda$. fastigiata Sweet (see below).

Azatea lucida Meerburgh, Pl. Selec. Icon. t. 7 (1798).

This species is described as with "foliis lanceolatis, flore luteo piloso, staminibus brevioribus. Cl. Linnaeus hanc descripsit pro Azalea nudiflora." The illustration resembles in general appearance $R$. nudiflorum, but the leaves are narrow-lanceolate, and the flowers have more the shape of those of $R$. viscosum and are colored light yellow. It possibly represents $R$. viscosum var. nitidum, and the yellowish tinge of the flowers may be a mistake of the artist.

Azalea nudiflora amoena Loddiges Cat. 1836, apud Loudon, Arb. Brit. II. 1142 (1838), name only.

Azatia nddiflora $\gamma$. Blanda Sweet, Hort. Brit. 265 (1826), name.-Loddiges, l.c.

Rhododendron nudiflorum $\gamma$. blandum Sweet, Hort. Brit. ed. 2, 343 (1830), "blush."

Azalea nudiflora $\beta$. calycosa Wood, Classb. Bot. 490 (1870).

This is a form from Georgia described as having one calyx-lobe subulate and three or four times longer than the others.

Azalea nudiflora e. Caroliniana Sweet, Hort. Brit. 265 (1826), - Loddigeg Cat. 1836 apud Loudon, Arb. Brit. II. 1142 (1838), name only.

? Azalea caroliniana in Cat. Am. Trees \& Shrubs in John Bartram's Garden (179?), name only. (1830).

Rhododendron nudiflorum є. carolinianum Sweet, Hort. Brit. ed. 2, 343

In Bartram's Catalogue it is called "Sweet Honeysuckle," which would suggest that it is one of the fragrant species.

Azalea nUdFlora CoBurgia Loddiges, l. c. 1142 (1838).

Azatiea nudfilora colorata Loddiges, l. c. 1142 (1838).

Azalea nudflora conspicua Loddiges, l. c. 1142 (1838), name.

Azalea NUdiflora $\eta$. CORYMBosa Sweet, l. c. 265 (1826), name.

Rhododendron nudiflorum 7. corymbosum Sweet, l.c. 343 (1830), "white."

Azalea nudiflora $\theta$. Crispa Sweet, l. c. 265 (1826), name. - Loddiges, $l$. $c$. 1142 (1838).

Rhododendron nudiflorum $\theta$. crispum Sweet, l. c. 343 (1830), "blush."

Azalea nudiflora i. comulata Sweet, l. c. 265 (1826), name. - Loddiges, l.c. 1142 (1838), as var. cumula.

Rhododendron nudiflorum ı. cumulatum Sweet, l.c. 344 (1830), "white."

Azalea NUdiflora к. Discolor Sweet, l. c. 265 (1826), name. - Loddiges, l. c. 1142 (1838).

Rhododendron nudiflorum к. discolor Sweet, l. c. 344 (1830), "red, white."

Azalea NUdiflora $\lambda$. Fastigiata Sweet, l. c. 265 (1826), name. - Loddiges, l. e. 1142 (1838).

Rhododendron nudiflorum $\lambda$. fastigiatum Sweet, l. c. 344 (1830), "blush."

Azalea NUdiflora n. Florma Sweet, l. c. 265 (1826), name. - Loddiges, l.c. 1142 (1838).

Rhododendron nudiflorum $\mu$. floridum Sweet, l. c. 344 (1830), "blugh." 
Azalea NUdiflora $\nu$. Globosa Sweet, l. c. 265 (1826), name. - Loddiges, $l$. c. 1142 (1838).

Rhododendron nudiflorum $\nu$. globosum Sweet, l.c. 344 (1830) "blush."

Azalea Nudiflora $\xi$. glomerata Sweet, l. c. 265 (1826), name.

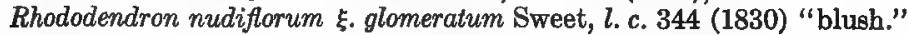

Azalea nUdiflora grandiflora Loddiges, l.c. 1142 (1838).

Azaliga nUdiflora o. incana Sweet, l. c. 265 (1826), name.-Loddiges, $l$. $c$. (1838).

Rhododendron nudiflorum o. incanum Sweet, l.c. 344 (1830) "white."

Azalea nUdiflora $\pi$. incarnata Sweet, l.c. 265 (1826), name.-Loddigeg, l. c. 1142 (1838).

Rhododendron nudiflorum $\pi$. incarnatum Sweet, l.c. 344 (1830) "flesh-colored."

Azaldea NUdiflora p. MIRabilis Sweet, l.c. 265 (1826), name. - Loddiges, l. c. 1142 (1838).

Rhododendron nudiflorum p. mirabile Sweet, l. c. 344 (1830), "red."

Azatea nUdiflona e. MIXta De Candolle, Prodr. VII. 717 (1839).

Described as having pale rose-colored flowers with the lower lobe inside yellowish and with a small calyx.

Azaliea nUdiflora $\sigma$. montana Sweet, $l$. c. 265 (1826), name. - Loddiges, $l$. $c$. 1142 (1838).

Rhododendron nudiflorum $\sigma$. montanum Sweet, l. c. 265 (1830), "flesh-colored."

Azalea nUdiflora ochroledca Loddiges, l. c. 1142 (1838), name.

Azalea NUDIFlora $\tau$. Pallida Sweet, l.c. 265 (1826).

Rhododendron nudiflorum r. pallidum Sweet, l. c. 344 (1826), "lilac white."

Azalea nUdiflora v. Paldoosa Sweet, l.c. 265 (1826), "lilac white." - Loddiges, l. c. 1142 (1838).

Rhododendron nudiflorum v. paludosum Sweet, l. c. 344 (1830), as var. pallidosa.

Azalea nUdiflora $\zeta$. Papilionacea Aiton, Hort. Kew. I. 203 (1789). - De Candolle, Prodr: VII. 717 (1838).

Azalea papilionacea Dumont de Courset, Bot. Cult. ed. 2, III. 333 (1811), as var. of $A$. nudiflora.

Azalea periclymenoides var. є. papilionacea Pursh, Fl. Am. Sept. 152 (1814).

Rhododendron nudiflorum $\phi$. papilionaceum Sweet, Hort. Brit. ed. 2,344 (1830).-

G. Don, Gen. Syst. III. 847 (1834).

This form is described by Aiton as having pale reddish flowers with the lower lobe white, and a foliaceous calyx.

Azalea nUdiflora $\eta$. Partita Aiton, Hort. Kew. I. 203 (1789). - De Candolle, Prodr. VII. 717 (1838).

Azalea periclymenoides $\zeta$. partita Pursh, Fl. Am. Sept. 152 (1814).

Rhododendron nudiflorum $\chi$. partitum Sweet, Hort. Brit. ed. 2, 344 (1830). -

G. Don, Gen. Syst. III. 847 (1834).

This form is described by Aiton as having pink flowers 5-parted to the base. This is apparently an abnormal form corresponding to Kalmia latifolia f. monstrosa. It seems to have soon disappeared from cultivation.

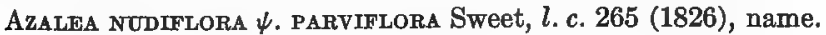

Rhododendron nudiflorum $\psi$. parviflorum Sweet. l.c. 344 (1830), "blush."

Azalea NUDiflora PERICLYMENoIdes Loddiges, l.c. (1838), name.

Azalea nUdiflora $\lambda$. Polyandra De Candolle, Prodr. VII. 717 (1838). Wood, Classb. Bot. 490 (1870).

Azalea periclymenoides $\eta$. polyandra Pursh, Fl. Am. Sept. 152 (1814). 
Rhododendron nudiflorum $\eta$. polyandrum G. Don, Gen. Syst. III. 847 (1834).

? Azalea octandra Michaux, Journal, ed. C. S. Sargent, 91 (in Proc. Am. Philos.

Soc. (1889)), name only.

This form is described by Pursh as having short rose-colored flowers with 10 to 20 stamens and is said to have been found near Philadelphia. Michaux collected his Azalea octandra in or in the neighborhood of Perry County, Pennsylvania.

Azales NODIFlora $\omega$. PRolifera Sweet, l. c. 265 (1826), name.

Rhododendron nudiflorum w. proliferum Sweet, l.c. 344 (1830), "blush."

Azalma NODIflora aa. PUMTha Sweet, l. c. 265 (1826), name.

Rhododendron nudiflorum aa. pumilum Sweet, l. c. 344 (1830), "blush."

Azalina Nudiflora $\beta \beta$. PURPURAscens Sweet, l.c. 265 (1826), name. - Loddiges, 2. c. 1142 (1838).

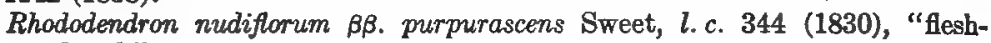
colored."

Azaliea NUDIFlora $\gamma \gamma$. PURPURea Sweet, l. c. 265 (1826), name.-Loddiges, l. c. (1838).

Rhododendron nudiflorum $\gamma \gamma$. purpureum Sweet, l. c. 344 (1830), "purple."

Aralifa NUdiflora 5 5. RUBERRIMA Sweet, $l$. c. 265 (1826), name. - Loddiges, l. c. 1142 (1838).

Rhododendron nudiflorum $\zeta$ ร. ruberrimum Sweet, l. c. 344 (1830), "red."

Azalea NUdiflora $\eta \eta$. RUBescens, Sweet, l. c. 265 (1826), name.

Rhododendron nudiflorum $\eta$. rubescens Sweet, l. c. 344 (1830), "pink."

Azanea nUdFlora $\lambda \lambda$. RUFA Sweet, l.c. 265 (1826), name. - Loddiges l. $c$. 1142 (1838).

Rhododendron nudiflorum $\lambda \lambda$. rufum Sweet, l. c. 344 (1830), "red."

AzaLEA NUDIFLORA vy. SEMT-DUPLEX Sweet, l.c. 265 (1826), name.

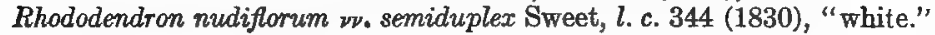

Azamia nudiflora $\beta$. RUtilans Aiton, Hort. Kew. I. 203 (1789). - De Candolle, Prodr. VII. 717 (1838).

Azalea rubicunda Dumont de Courset, Bot. Cult. ed. 2, III. 332 (1811), as var. of $A$. nudiflora.

Azalea periclymenoides $\beta$. rutilans Pursh, Fl. Am. Sept. 152 (1814).

Rhododendron nudiflorum $\mu$. rutilans Sweet, Hort. Brit. ed. 2, 343 (1830). - G. Don, Gen. Syst. III. 847 (1834).

Azalea nudiflora rubicunda Loddiges Cat. 1836 apud Loudon, Arb. Brit. II. 1142 (1838).

A zalea nudiflora $\theta \theta$. rubicunda Sweet, Hort. Brit. 265 (1826).

Rhododendron nudiflorum $\theta \theta$. rubicundum Sweet, Hort. Brit. ed. 2, 343 (1830).

This form is described by Aiton as having deep red flowers with small calyx. Dumont de Courset says that the young branchlets and the leaves are pubescent, the calyx greenish brown and the winter-buds pale yellow in autumn.

Azalea nudiflora serotina Loddiges, l. c. 1142 (1838), name.

Agatian nudflora $\xi \xi$. staminea Sweet, l. c. 265 (1826), name.-Loddiges, l. c. 1142 (1838).

Rhododendron nudiflorum $\xi \xi$. stamineum Sweet, l.c. 344 (1830), "white."

Azalia nodiflora oo. stellata Sweet, l. c. 265 (1826), name.-Loddiges, l. c. (1838).

Rhododendron nudiflorum oo. stellatum Sweet, l. c. 344 (1830), "white."

Aralea nUdiflora varia Loddiges, l. c. 1142 (1838), name. 
Azaliga NUdiflora $\rho \rho$. variabilis Sweet, l. c. 266 (1826), name. - Loddiges, l. c. 1142 (1838).

Rhododendron nudiflorum po. variabilis Sweet, l. c. 344 (1830), "red, white."

Azalea nUdiflora $\sigma \sigma$. Variegata Sweet, l. c. 266 (1826), name. - Loddiges, l. c. (1838).

Rhododendron nudiflorum $\sigma \sigma$. variegatum Sweet, l.c. 344 (1830), "striped."

Azalea NUdiflora tr. Versicolor Sweet, l.c. 266 (1826), name. - Loddiges, l. c. 1142 (1838).

Rhododendron nudiflorum $\tau \tau$, versicolor Sweet, l. c. 344 (1830), "red, white."

Azalea Nudiflora vv. violacea Sweet, $l$. c. 266 (1826), name. - Loddiges, l. c. (1838).

Rhododendron nudiflorum vv. violaceum Sweet, l. c. 344 (1830), "violet."

Azalea PUlchella carminea Hort. apud Kirchner in Petzold \& Kirchner, Arb. Musc. 480 (1864).

Described as with deep carmine flowers in flattened umbels.

Azalea pulchella roseola Hort. apud Kirchner, l. c. 480 (1864).

Described as having crowded small rose-colored flowers.

Azalta RUBra Weston, Bot. Cult. I. 16 (1770). - Meerburgh, Pl. Select. Icon. (7) t. 8 (1798).

By Weston this species is characterized as a red-flowered Azalea nudiflora. Also Meerburgh's plate represents apparently $R$. nudiflorum and judging from the hirsute corolla-tube the typical form; it is therefore not identical with Azalea nudiflora rubra of Loddiges (see page 138).

Azalea salicifolia Dumont de Courset, Bot. Cult. VII. 166 (1814).

Described as having willow-like leaves.

Azalea speciosa «. ACtTifolia Sweet, Hort. Brit. 265 (1826), name.

Rhododendron speciosum ı. acutifolium Sweet, Hort. Brit. ed. 2, 343 (1830) "red."

Azalea speciosa $\theta$. ciltata Sweet, l. c. 265 (1826), name.

Rhododendron speciosum $\theta$. ciliatum Sweet, l. c. 343 (1830) "red."

Azalea speciosa coccinea Kirchner in Petzold \& Kirchner, Arb. Musc. 479 (1864).

Flowers described as bright scarlet or garnet-red. This is probably typical R. specioşum.

Azadea speciosa $\beta$. CRISPA Sweet, Hort. Brit. 265 (1826), name.

Rhododendron speciosum B. crispum Sweet, Hort. Brit. ed. 2, 343 (1830), "scarlet."

Azalea speciosa $\zeta$. cucollata Sweet, l. c. 265 (1826), name.

Rhododendron speciosum $\zeta$. culcullatum Sweet, l.c. 343 (1830), "red."

Azalea speciosa $\delta$. obliqua Sweet, l. c. 265 (1826), name.

Rhododendron speciosum $\delta$. obliquum Sweet, l. c. 343 (1830), "red."

Azalea speciosa $\epsilon$. PRUnifolia Sweet, l. c. 265 (1826), name.

Rhododendron speciosum €. prunifolium Sweet, l. c. 343 (1830), "red."

Azalea speciosa pURpUReo-AURANTiaCa Kirchner, l.c. 479 (1864), name.

Azalea speciosa $\eta$. Revoldta Sweet, l.c. 265 (1826), name.

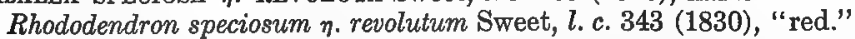

Azalea speciosa $\lambda$ ToRtulifolia Sweet, l. c. 265 (1826), name.

Rhododendron spcciosum $\lambda$. tortulifolium Sweet, l. c. 343 (1830), "red."

Rhododendron speciosum $\lambda$. tortuifolium Sweet, l.c. ed. 3, 443 (1839). 
Azaliga speciosa $\kappa$. Undulata Sweet, l.c. 265 (1826), name.

Rhododendron speciosum к. undulatum Sweet, l. c. 343 (1830), "red."

Azalea viscosa $\beta$. CRIsPa Sweet, Hort. Brit. 266 (1826). - Loddiges, Cat. apud Loudon, Arb. Brit. II. 1143 (1838).

Rhododendron viscosum $\beta$. crispum Sweet, Hort. Brit. ed. 2, 344 (1830), "white."

Azalfa viscosa $\gamma$. Deanbata Sweet, l. c. 266 (1826). - Loddiges, l. c. 1143 (1838).

Rhododendron viscosum $\gamma$. dealbatum Sweet, l. c. 344 (1830), "white."

Azalea viscosa e. Penicitituata Sweet, l. c. 266 (1826). - Loddiges, l. c. 1143 (1838).

Rhododendron viscosum є. penicillatum Sweet, l. c. 344 (1830), "red, white."

Azalea viscosa praecox Loddiges, l. c. 1143 (1838), name.

Azalea viscosa stricta Carrière in Rev. Hort. 1872, p. 299.

Described as a very dwarf compact plant, with oval leaves glaucous beneath and small white slightly pinkish flowers appearing at the beginning of May. The early flowering time makes it improbable that this form belongs to $R$. viscosum.

Azalea viscosa 5. vartegata Sweet, l.c. 265 (1826). - Loddiges, l.c. 1143 (1838).

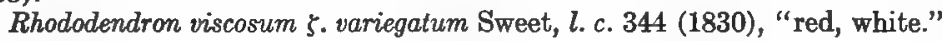

Azalea viscosa viotaf odore Loddiges, l.c. 1143 (1838), name.

Besides the doubtful names enumerated above, a large number of names without or with very inadequate description have appeared in horticultural publications taken in about all cases from various nursery catalogues. The following are some of the more important references to lists of garden forms of Azaleas (exclusive of Indian Azaleas):

Loudon, Arb. Brit. II. 1142-1144 (1838).

Bosse, Vollst. Handb. Blumengärt. I. 337, 340-342 (1840).

Heynhold, Nomencl. Bot. Hort. 108 (1840); II. 55-56 (1846).

Steudel, Nomencl. I. 175 (1841).

Henderson, $I l l$. Bouquet, text to t. 46 (1859-61), forms of $R$. norbitonense.

André, Pl. Terr. Bruy. 164, 166, 187-189 (1864).

Millais, Rhodod. 166-167, 212-214 (1917). 


\section{ILLUSTRATIONS}

References to illustrations of garden forms (exclusive of Indian Azaleas) not mentioned elsewhere in this publication. They are mostly forms of $R$. gandavense or $R$. Mortieri if not stated otherwise.

ANTHONY Koster. Gard. Chron. ser. 3, XIII. 513, fig. 76 (1893). - Watson, Rhodod. \& Azaleas, frontisp. (1912) $=R$. Kosterianum.

Atrontbens Nova. Lemaire in Ill. Hort. II. pl. 75, fig. 15 (1855).

Baron G. Pycke. Lemaire, l. c. fig. 16 (1855).

BeadTé DE FLandRe. Lemaire, $l$. c. fig. 9 (1855).

Bujou De GendrRUGGe. Van Houtte in Fl. des Serr. XIX. t. 2024 (928) (1873)

$=R$. gandavense plenum .

BonNeUr De LA BeLGiQUe. Lemaire in Ill. Hort. II. pl. 75, fig. 4 (1855).

Botquet de Flore. Ottolander, Nederl. Fl. Pom. 53, t. 16 (1876).

Cardinal. Spae in Ann. Soc. Agtic. Bot. Gand, II. 326, t. 81, fig. 9 (1846).

Coccinea speciosa. Ottolander, Nederl. Fl. Pom. 5, t. 15, fig. 2 (1876).

Comte de Gomer. Rev. Hort. Belge, I. 97, t. 6 (1875).-Dean, Floral Mag.

n. ser. XVIII. t. $367(1879)=R$. japonicum var.

Comtesse De Kerchove. André in Ill. Hort. XXV. 59, t. $311(1878)=R$. japonicum var.

Coprea eximta nova. Osborn in Gard. XV. 318, t. 176 (1879).

Czarine. Pynaert \& Van Geert in Rev. Hort. Belg. XX. 277, t. (1894) $=R$. Kosterianum.

Delicata nova. Lemaire in Ill. Hort. II. pl. 75, fig. 10 (1855).

DUC D'URSEL. Lemaire, $l$. c. fig. 1 (1855).

ETENDARD. Morren in Ann. Soc. Agric. Bot. Gand, III. 9, t. 106, fig. 14 (1847).

E'UGENIE. Lemaire in Ill. Hort. II. pI. 75, fig. 6 (1855).

EdGénte. Ottolander, Nederl. Fl. Pom. 51, t. 15, fig. 3 (1876), not the same as the preceding variety.

Frorentina. Spae in Ann. Soc. Agric. Bot. Gand, II. 326, t. 81, fig. 6 (1846).

Françors De TAYe. Van Houtte in Fl. des Serr. XIX. t. 2023 (927) (1873) = $R$. gandavense plenum.

Grant Des batailles. Ottolander, Nederl. Fl. Pom. 51, t. 15, fig. 1 (1876).

Gloire de Verschaffett. Morren in Ann. Soc. Agric. Bot. Gand, III. 9, t. 106, fig. 16 (1847).

GraF von Meran. Rinz in Gartenfl. III. 171, t. 88 (1854). - Moore in Fl. Pomol. 1880, 89, t. 516, fig. 2, = R. gandavense plenum.

Grand-Duc. Spae in Ann. Soc. Agric. Bot. Gand, II. 326, t. 81, fig. 7 (1846).

Ignaea Nova. Ottolander, Nederl. Fl. Pom. 51, t. 15, fig. 5 (1876).

JAs. H. LAING. Pynaert \& Van Geert, Rev. Hort. Belg. XVII. 121, t. (1891) = R. Kosterianum. 
Lodis Aimé Van HodtTe. Van Houtte in Fl. des Serr. XIX. t. 2022 (929) $(1873)=R$. gandavense plenum.

Lodis Helleburck. Van Houtte in Fl. des Serr. XIX. t. 2019 (931) (1873).

Madame Alex. Hardy. Van Houtte in Fl. des Sert. XIX. t. 2020 (930) (1873).

Magnifica albicans. Lemaire in Ill. Hort. II. pl. 75, fig. 14 (1855).

Marie-Dorothét. Spae in Ann. Soc. Agric. Bot. Gand, II. 326, t. 81, fig. 5 (1846).

Mina VAN HodTTE. Van Houtte in Fl. des Serr. XIX. t. 2021 (926) (1873) =

$R$. gandavense plenum.

Minerve. Spae in Ann. Soc. Agric. Bot. Gand, II. 326, t. 81, fig. 10 (1846).

Mintata FLORIBUNDA. Lemaire in Ill. Hort. II. pl. 75, fig. 13 (1855).

Molilis var. aldicans. André in Ill. Hort. XXV. 59, t. $311(1878)=R . j a-$ ponicum var.

Mollis var. aURma Floribunda. André in $\mathrm{Ill}$. Hort. XXV. 91, t. $317(1878)=$ $\boldsymbol{R}$. japonicum var.

MurdLlo. Vandevoorde in Rev. Hort. Belg. XIX, 232, t. fig. $1(1893)=R$. mixtum.

NarCissiflora. Moore in Fl. Pomol. 1880, 89, t. 516, fig. $1(1880)=R$. gandavense plenum.

Ne PLUS Ultra. Osborn in Gard. XV. 318, t. 176 (1879).

NóroN. Lemaire in Ill. Hort. II. t. 75, fig. 7 (1855).

Nicolas II. Pynaert \& Van Geert in Rev. Hort. Belge, XX. 277, t. (1894) = R. Kosterianum.

NoBILIs. Lemaire in Ill. Hort. II. pl. 75, fig. 12 (1855).

Orange Peinte. Spae in Ann. Soc. Agric. Bot. Gand, II. 326, t. 81, fig. 2 (1846).

Oscar Premier. Morren in Ann. Soc. Agric. Bot. Gand, III. 9, t. 106, fig. 13 (1847).

Perle DU PRINTemps. Morren in Ann. Soc. Agric. Bot. Gand, II. 9, t. 106, fig. 19 (1847).

Pheвt. Vandervoorde in Rev. Hort. Belg. XIX. 232, t. fig. $3(1893)=$ R. mixtum.

Pontica Macrantha. Osborn in Gard. XV. 318, t. 176 (1879).

PonTICA VERsicolor. Osborn in Gard. XV. 318, t. 176 (1879).

Prince Henri des Pays-Bas. Spae in Ann. Soc. Agric. Bot. Gand, II. 326, t. 81, fig. 1 (1846).

Prince Troubetzkoy. André in Ill. Hort. XXV. 91, t. $317(1878)=R . j a$ ponicum var.

Qdadnicolore. Spae in Ann. Soc. Agric. Bot. Gand, II. 326, t. 81, fig. 8 (1846).

QUEEN Victoria. Van Hulle in Rev. Hort. Belge, III. 4, t. fig. 1 (1877).

Rayon du matin. Morren in Ann. Soc. Agric. Bot. Gand, II. 9, t. 106, fig. 18 (1847).

Ratne D'Angleterre. Spae in Ann. Soc. Agric. Bot. Gand, II. 326, t. 81, fig. 4 (1846).

RICEARDII. Lemaire in Ill. Hort. II. pl. 75, fig. 11 (1855).

Rosaue. Morren in Ann. Soc. Agric. Bot. Gand, III. 9, t. 106, fig. 15 (1847).

Rosea formosissima. Lemaire in $I l l$. Hort. II. pl. 75, fig. 3 (1855).

Rosea lineata. Lemaire, l. c. fig. 8 (1855). - Ottolander, Nederl. Fl. Pom. 51, t. 15, fig. 4 (1876).

ROSEA ROTUNDIFLORA. Lemaire, $l$. c. fig. 5 (1855).

Rubens. Spae in Ann. Soc. Agric. Bot. Gand, II. 326, t. 81, fig. 12 (1846).

RUBRA SPLENDDISSIMA. Lemaire in Ill. Hort. II. pl. 75, fig. 2 (1855). 
SAPPHO. Moore in $F l$. Pomol. 1880, 89, t. 516, fig. $3=R$. gandavense plenum. Sodpir du Crêpuscule. Morren in Ann. Soc. Agric. Bot. Gand, III. 9, t. 106, fig. 20 (1847).

Sooventr de Mortier. Van Hulle in Rev. Hort. Belge, III. 4, t. fig. 2 (1877). Souvenir De Roxgeem. Ottolander, Nederl. Fl. Pom. 51, t. 15, fig. 6 (1876). Spigelius. Morren in Ann. Soc. Agric. Bot. Gand, III. 9, t. 106, fig. 17 (1847).

Triomphe De Royghem. Spae in Ann. Soc. Agric. Bot. Gand, II. 326, fig. 3 (1846).

Tsarine. See Czarine.

VaN Drck. Spae in Ann. Soc. Agric. Bot. Gand, II. 326, t. 81, fig. 11 (1846).

VirgILE. Vandevoorde in Rev. Hort. Belg. XIX, 232, t. fig. 2 (1893). - Reiter in Gartenwelt, XV. 493, fig. (1911). = R. mixtum. 


\section{ADDITIONS}

P. 29. Add to the synonyms of $\mathbf{R}$. obtusum:

Rhododendron amoenum var. obtusum Zabel in Mitteil. Deutsch. Dendr. Ges. XI. 35 (1902).

P. 32. Add to the synonyms of R. obtusum f. amoenum:

Rhododendrom amoenum var. eusamoenum Zabel in Mitteil. Deutsch. Dendr. Ges. XI. 35 (1902).

Rhododendron amoenum subvar. normale Zabel, $l$. c. (1902).

Rhododendron amoenum subvar. genuinum Zabel, l. c. (1902).

Rhododendron amoenum subvar. Buergeri Zabel, l. c. (1902).

P. 33. Add to the synonyms of $\mathbf{R}$. obtusum $\mathbf{f}$. japonicum:

Rhododendron amoenum subvar. japonicum, Zabel in Mitteil. Deutsch. Dendr. Ges. XI. 35 (1902).

P. 105. Add as a doubtful name:

Rhododendron boninense Nakai in Tokyo Bot. Mag. XXXIV. (324) (1920), name only. 
INDEX 



\section{INDEX}

Synonyms are printed in Italics; new names and new combinations in bold-face type; garden names and doubtful names under Azalea in Roman.

Anthodendron, 115

- flanum, 103

- nudiflorum, 135

- ponticum, 103

- viscosum, 158

Azalea, 22, 115, 124

- subgen. Euazalea, 79, 124

- subgen. Pentanthera, 124

- subgen. Tsutsutsi, 22

- Agemaki, 38

- Aioi, 38

- Aka-yodogawa, 64

- $a l b a, 68,137$

- Alba insignis, 48

- albicans, 180

- Albrechtii, 91

- Alice Sargent, 44

- altaclarensis, 182

- Alphonse Lavallée, 102

- America, 71

- amoena, 32

- - alba, 31

- - Caldwelli, 32

- - Hatsu-giri, 32

- Anthony Koster, 203

- arborea, 103, 167

- arborescens, 166

- Asagasumi, 37

- atlantica, 148

- - luteo-alba, 150

- Atrorubens nova, 203

- auranitiaca, 128, 130

- austrina, 146

- Avalanche, 182

- Aya Kammuri, 37

- Azuma Kagami, 37

- balsaminaeflora, 26

- Baron Edmond de Rothschild, 102

- Baron G. Pycke, 203

- Baroness Rothschild, 97

- Bealii, 49

- Beauté de Flandre, 203

- Benifude, 37

- Beni-renge-tsutsiji, 101

- bicolor, 143

- Bijinsui, 37

- Bijou de Gandbrugge, 203

- Bonneur de la Belgique, 203

- Botan tsutsuji, 65
Azalea Bouquet de Flore, 203

- Breynii, 23

- Bride, 25

- Brookline, 44

- calendulacea, 126, 127, 132

- — alba bicolor, 197

- - astreans, 197

- - chrysolecta, 197

- - coccinea fulgens, 197

- - cristata, 197

- - crocea, 130

- - cupraea, 139

- - cuprea elegans, 197

- - fenestrata, 197

- flammea, 131, 176

- frigida, 177

- - fulgens excelsa, 197

- - fulgida, 177

- - fulgina, 177

- grandiflora, 197

- - ignescens, 197

- L lepida, 177

- - Morterii, 176

- - recurva, 197

- - sanguinea, 197

- Saturnea, 197

- - splendens, 197

- Stapletoniana, 177

- - Sterniana, 198

- - subcuprea, 177

- - triumphans, 198

- var. a, 131

- -a., 130

- californica, 126

- canadensis, 121

- candida, 146

- canescens, 139, 143

- Cardinal, 203

- carnea, 137

- caroliniana, 168, 198

- Centi Striatella, 97

- Charles Encke, 27

- Charles Kékulé, 102

- Chevalier A. de Réali, 102

- coccinea, 131

- - aurantia, 131

- - major, 130, 131

- Coccinea speciosa, 203

- Comte de Gomer, 102, 203 
A zalea Comte Papadopoli, 102

- Comtesse de Kerchove, 203

- Consul Pêcher, 102

- crispiflora, 27

- Cuprea eximia nova, 203

- Czarine, 203

- Damask Rose, 72

- Danielsiana, 23

- Daviesii, 182

- Decora, 44

- decumbens, 23

- Delicata nova, 203

- dianthiflora, 76

- dilatata, 84

- Director Rodigas, 99

- Double Blush, 138

- Dr. Masters, 99

- Duc de Nassau, 44

- Duc d'Ursel, 203

- Ebenezer Pyke, 97

- Edouard André, 99

- Eeckhautei, 187

- erecta folizs ovatis integris alternis flore luteo piloso praecoci, 128

- Etendard, 203

- Eugénie, 203

- Exquisite, 98, 180

- fasciculata, 198

- fastigiata, 198

- Farrerae, 80

- fimbriata, 105

- Firefly, 33, 44

- fissa, 166

- Flambeau, 44

- flammea, 127

- flava, 103, 128

- Florentina, 203

- floribunda, 161

- fragrans, 167, 190

- François de Taye, 203

- Fudesute Yama, 37

- Fuji-manyo, 64

- fulva, 131

- Fürstin Baro Trysky, 49

- Gandavensis, 179

- Garnet, 43, 44

- Géant des batailles, 203

- glauca, 161

- - flore semipleno, 166

- - hispida, 163

- - plena, 166

- - purpurascens, 161

- - rosea, 161

- Gledstanesii, 27

- Gloire de Verschaffelt, 203

- Goldlack, 103

- Gosho Zakura, 38

- Graciosa, 98, 180

- Graf von Meran, 98, 203

— Grand-Duc, 203
Azalea Hachika Teugi, 37

- Hana Asobi, 38

- Hana-guruma, 78

- Hatsu-giri, 33

- Havemeyer, 44

- Hebe, 44

- Helena, 44

- Hermione, 44

- Hexe, 33, 44

- Hilda Hedlund, 44

- Hinodegiri, 38

- Hinode No Taka, 38

- Hino-tsukasa, 30

- Hiryu, 30

- hispida, 163

- Hiwoge-yodogawa, 60

- Holm Lea, 44

- Hoō, 37

- hybrida Daviesii, 182

- enneandra, 190

- Ignaea nova, 203

- indica, 22, 29, 38, 45

- - alba, 68

- - amoena, 32

- - angustifolia, 23

- calycina, 63

- - crispiflora, 27

- - exquisita, 26

- floribunda, 23

- - grandiflora, 27

- Hexe, 44

- hybrida, 62

- - ignescens, 45

- Iveryana albo-cincta, 26

- Kaempferi, 38

- - lateritia, 23

- - obtusa, 29

- - obtusa alba, 31

- - phoenicea, 61

- plena, 73

- - punctulata, 25

- - punicea, 45

- - purpurea, 73

- - purpurea plena, 73

- Rawsonii, 61

- - roseum, 72

- - rosiflora, 26

- Simsii, 45

- - spatulata, 23

- var. $\gamma_{., 61}$

- - variegata, 26

- - viltata, 48

- vitlata punctata, 49

- Ima Shōjō, 37

- Irohayama, 37

- Iso-tsutsuji, 73

- Iveryana, 27

- japonica, 99

- - alba grandiflora Van Noordt, 71

- - grandiflora superba, 72 
Azalea Jas. H. Laing, 203

- Jedogawa-tsutsuji, 70

- J. T. Lovett, 25

- Jupiter, 44

- Kaempferi, 38

- Kasane Kagaribi, 37

- Kasumi Gaseki, 37

- Katsura No Hana, 37

- Kimigayo, 37

- Kin-no-zai, 27

- Kinshibe-tsutsuji, 42

- Ki-renge-tsutsuji, 102

- Kirin, 37

- Kirishima-tsutsuji, 30

- Kiritsubo, 37

- Ki-tsutsuji, 102

- Kochonomai, 33

- Kocho-zoroi, 77

- Komanyo-satsuki, 26

- Kumagai-yodogawa, 64

- Kumo No Uye, 37

- Kurai No Himo, 38

- Kureno Yuki, 37

- Kurofune-tsutsuji, 90

- lateritia, 23

- ledifolia, 68

- - alba pleno, 72

- Noordtiana, 71

- phoenicea, 62

- liliiflora, 68

- linearifolia 74

- Louis Aimé Van Houtte, 98, 204

- Louis Hellebuyck, 204

- lucida, 198

- lucida, 162

- lugens, 105

- lutea, 127, 134, 143

- macrantha, 23

- macrosepala, 75

- Madame Alex. Hardy, 204

- Madame Camille van Langenhone, 97

- Magnifica, 98

- magnifica, 72, 192

- Magnifica albicans, 204

- marginata, 181

- Marie-Dorothée, 204

- Mars, 44

- Mattapan, 71

- Maxwellii, 64

- Milton, 98

- Mina Van Houtte, 204

- Minerve, 204

- Miniata floribunda, 204

- Miss Louisa Hunnewell, 97

- Mochi-tsutsuji, 75

- mollis, 95, 100

- Mollis var. albicans, 204

- Mollis var. aurea foribunda, 204

- mollis flore-pleno, 183
Azalea mollis glabrior, 99

$--\times$ sinensis, 97

- Momo-iro-yodogawa, 73

- Mortieri, 176

- Mortieriana, 176, 179

- Mrs. Carmichael, 33

- mucronata, 68

- Murasaki-botan-tsutsuji, 73

- Murasaki Yama-tsutsuji, 43

- Muriel, 44

- Murillo, 98, 204

- Nani Wagata, 37

- narcissiflora, 71, 98, 204

- Natalie, 44

- neglecta, 149

- Ne plus ultra, 204

- Néron, 204

- Nicolas II, 204

- nitida, 157, 162

- Nobilis, 204

- Nonpareil, 97

- nudiflora, 127, 131, 134, 139, 143, 147

- - alba, 137, 141

- - albo-plena, 138

- - amoena, 198

- - bicolor, 143

- - blanda, 198

- - calycosa, 198

- canescens, 143

- - carnea, 137

- - caroliniana, 198

- - ciliata, 126

- Coburgia, 198

- coccinea, 131

- - colorata, 198

- - conspicua, 198

- - corymbosa, 198

- crispa, 198

- - cumulata, 198

- - discolor, 198

- - fastigiata, 198

- - flore pleno, 138

- - florida, 198

- - glandifera, 138

- - globosa, 199

- - glomerata, 199

- - grandiflora, 199

- - incana, 199

- - incarnata, 199

- - lutea, 128

- - mirabilis, 199

- - mixta, 199

- montana, 199

- - ochroleuca, 199

- - pallida, 199

- - paludosa, 199

- - papilionacea, 199

- - partita, 199

— - parviflora, 199

_ - periclymenoides, 199 
Azalea nudiflora periclymenoides, 135

- - polyandra, 199

- prolifera, 200

- - pumila, 200

- - purpurascens, 200

- - purpurea, 200

- - purpureo-plena, 138

- - rosea, 139

- - ruberrima, 200

- - rubescens, 200

- rubicunda, 200

- - rubra, 138

- - rubro-plena, 138

- - rufa, 200

- - rutilans, 200

- - rutilans, 132

- - scintillans, 178

- - semi-duplex, 200

- - semi-duplex, 138

- - serotina, 200

- staminea, 200

- - stellata, 200

- thyrsiflora, 132

- - tricolor, 176

- - varia, 200

- - variabilis, 201

- - variegata, 201

- - versicolor, 201 violacea, 201

$-\ldots$ sinensis, 183

- oblongifolia, 150

- obtusa, 29

- - alba, 31

- occidentalis, 126 "Hybrids," 98

- $\times$ arborescens $\times$ mollis, 180

- octandra, 200

- odorata, 190

- Oinō Mezame, 37

- Oldhamii, 67

- Omoine, 37

- Omurasaki-tsutsuji, 62, 63

- Optima, 48

- Orange peinte, 204

- O-riukiu-tsutsuji, 71

- Osaraku, 37

- Osaraku Seedling, 38

- Oscar premier, 204

- Otome, 37

- Oyeyama-tsutsuji, 78

- pallida, 190

- papilionacea, 199

- periclymena, 135

- periclymenoides, 135

- - alba pleno, 138

- carnea, 137

- - coccinea, 131

- papilionacea, 199

- - partita, 199

— - polyandra, 199
Azalea periclymenoides rubra pleno, 138 - - rutilans, 200

- Perle du printemps, 204

- Phébé, 204

- phoenicea, 61

- pontica, 103

- - autumnalis, 103

- calendulacea, 128

- coronaria $\beta$. ardens, 178

- coronaria a. flanum, 178

- flava, 103

- Goldlack, 103

- - macrantha, 204

- - sinensis, 95

- - et var., 179

- - versicolor, 177, 204

- - X evergreen Rhododendron, 192

- pontica-rubescens, 178

- Prince Albert, 48

- Prince Henri des Pays-Bas, 204

- Prince Troubetzkoy, 204

- prinophylla, 139

- prolifera, 73

- prunifolia, 169

- pulchella carminea, 201

- - roseola, 201

- punctata, 105

- punctulata omnicolor, 25

- - variegata, 25

- punicea, 61

- purpurea pleno, 73

- Quadricolore, 204

- Queen Victoria, 204

- quinquefolia pink, 93

- Racine, 98

- ramentacea, 31

- ramis infra foliosis, 158

- Rashō Mon, 37

- Rawsonii, 61, 196

- Rayon du Matin, 204

- Reine d'Angleterre, 204

- Reine Louise, 27

- Renge-tsutsuji, 101

- reticulata, 84

- Reyndersiana, 196

- rhombica, 84

- Rice Azalea, 54

- Richardii, 204

- Rjuku Tsutsusi fl. igneo, 103

- Rollissoni, 26

- rosaeflora, 26

- Rosalie, 204

- rosea, 138

- Rosea formosissima, 204

- - lineata, 204

- - rotundiflora, 204

- Rose Queen, 44

- rosmarinifolia, 68

- $-a b b a, 69$

- narcissiflora, 71 
Azalea rosmarinifolia purpurea, 63

- Rubens, 204

- rubicunda, 200

- rubra, 201

- Rubra splendidissima, 204

- Ruby, 44

- rustica flore-pleno, 98, 183

- Sakura Tsukasa, 38

- salicifolia, 201

- Saotome, 37

- Sappho, 205

- Satsuki, 25

- Satsuki-tsutsuji, 24

- scabra, 161, 163

- scapo nudo floribus confertis terminatricibus staminibus declinatis, 135

- Schlippenbachii, 89

- Schöne von Giessen, 181

- Seikai, 37

- Seikan-tsutsuji, 77

- serotina, 166

- serpyllifolia, 53

- serrulata, 153

- Seymouri, 185

- Shide-satsuki, 27

- Shiki-takane-satsuki, 26

- Shin Seikai, 37

- Shintoki No Hagasane, 26

- Shin Utena, 37

- Shirobana-unzen-tsutsuji, 54

- Shiro-manyo-tsutsuji, 72

- Shiro-yodogawa, 70

- sinensis, 95

- - alba, 183

- Bylsiana, 183

- - coccinea, 181

- - genuina, 95

- - glabrior, 99

- macrantha, 183

- Soupir du Crépuscule, 205

- Souvenir de Mortier, 205

- Souvenir de Royghem, 205

- spathulata, 162

- speciosa, 131

- - acutifolia, 201

- - aurantia, 131

- - aurantiaca, 131

- ciliata, 201

- - coccinea, 201

- - coccinea, 132

- - crispa, 201

- - cucullata, 201

- - major, 131

- obliqua, 201

- - prunifolia, 201

- - purpureo-aurantiaca, 201

- - revoluta, 201

- - tortulifolia, 201

- - undulata, 202

- Spigelius, 205
Azalea squamata, 80

- squamosa, 80

- sublanceolata, 59

- Suetsumu, 37

- Suga No Ito, 37

- Suiyōhi, 37

- Superba, 98

- Tado Guno, 64

- Takasago, 37

- Tamafuyo, 37

- Tama No Utena, 38

- Tancho, 37

- Tasso, 98

- The Bride, 25

- Thunbergii, 29

- Token, 25

- tomentosa, 162

- tricolor, 176

- Triomphe de Royghem, 205

- Taarine, 205

- Tschonoskii, 55

- Tsuta Momiji, 37

- Ukamuse, 38

- Uncas, 44

- Van Dyck, 205

- Van Houltei flore pleno, 179

- Vaseyi, 122

- Venus, 44

- Verna Berger, 181

- versicolor grandiflora, 177

- verticillata, 167

- Vervaeniana, 48

- - alba, 48

- Victoria regina, 99, 193

- virens, 157

- Virgil, 183

- Virgile, 98, 205

- viscosa, 153, 157, 166

- - crispa, 202

- - dealbata, 202

- - fissa, 166

- - flore pleno, 166

- - foribunda, 161

- - glauca, 161

- - glauca flore pleno, 166

- - hispida, 163

- nitida, 162

- ornata, 178

- - palustris, 157

- - penicillata, 202

- - praecox, 202

- - pubescens, 161

- _ rubescens, 161

- - stricta, 202

- - tomentosa, 162

- - variegata, 202

- - violae odore, 202

- viscocephala, 182

- viscosepala, 182

- vittata, 48, 105 
Azalea vittata Bealii, 49

- vittalo-punctata, 49

- Vivid, 44

- Vulcan, 44

- Vuylestekeana, 44

- Waka Kayede, 37

- Weyrichii, 82

- Yama tsutsuji, 40

- Yayegiri, 30

- Yayehiryu, 37

- Yedogawa Satsuke, 70

- Yin-shan-hung, 47

- Yodogava, 64

- Yorozuyo, 37

Azaleae Gandavenses, 179

- Mortierianae, 176, 179

Azaleodendron, 188, 194

- "Comte de Kerchove," 194

Beverinckia, 22

Bilitia, 119

- Vaseyi, 122

Chamaerhodendron exoticum amplissimis floribus litiaceis, 24

Chamaerhododendros, 121

- Pontica maxima Mespili folio flore luteo, 104

- Virginiana Periclymeni flore ampliori minus odorato, 135

Cistus Indicus Ledi Alpini foliis \& floribus amplis, 25

- Virginiana flore et Qdore Periclymeni, 143

- - flore et odore Periclymeni, 158

- Periclymeni flore ampliori et minus odorato, 135

Hochenwartia, 119

- canadensis, 120

Loiseleria, 22

Osmothamnus fragrans, 191

- pallidus, 191

\section{Rhodazalea, 188}

- Crouxii, 194

- flore pleno, 195

Rhododendro-Azalea, 188

Rhododendron a. Anthodendron, 115, 124

- sect. A zalea, 79, 119, 124

- sect. Euazalea, 124

- sect. Pentanthera, 95, 124

- sect. Pentanthera, 115

- sect. Pentanthera $\times$ Leiorhodion, 188

- sect. Pentanthera $\times$ Rhodora, 185

- sect. Rhodora, 91, 119

- sect. Rhodora, 79
Rhododendron sect. Sciadorhodion, 79

- sect. Toutousi, 22

- sect. Tsusia, 22

- sect. Tsutsugi, 22

- sect. Tsutsutsi, 22, 79, 187

- subgen. Anthodendron, 115

- subgen. Anthodendron $\times$ Eurhodendron, 188

- subgen. Azalea, 115

- subgen. Tsutsia, 22, 79

- Adamsii, 190

- alabamense, 141

- albicans, 97, 180

- Albrechtii, 91

- amoenum, 32

- - Buergeri, 206

- euamoenum, 206

- - genuinum, 206

- - japonicum, 33, 206

- - normale, 206

- - obtusum, 206

- Anneliesae, 181

- arborescens, 166

- - Richardsonii, 168

- $\times$ calendulaceum, 181

- $\times$ Mortieri, 178

- atlanticum, 147

- - luteo-album, 150

- - neglectum, 149

- atrovirens, 50

- austrinum, 146

- azaleodendron, 194

- azaleoides, 188

- azaleoides, 190, 191

- - alba odorata, 190

- crispiflorium, 196

- - inodorum, 188

- - odoratum, 190

- bicolor, 143

- bigener, 189

- boninense, 206

- breviperulatum, 28

- Breynii, 23

- broughtonianum, 194

- brougtonii aureum, 99

- broughtonii aureum, 194

- Buergeri, 32

- Burmanni, 68

- calendulaceum, 127

- calendulaceum, 132

- - aurantiacum, 131

- aurantium, 130

- chrysolectum, 197

- - croceum, 130

- - cupreum, 139

- - flammeum, 131

- - fulgidum, 177

- - grandiflorum, 197

- - ignescens, 197

- - lepidum, 177 
RhododendroncalendulaceumMorteri,176 - - speciosum, 132

- splendens, 197

- Stapletonianum, 177

- - subcupreum, 177

- - triumphans, 198

- $\times$ ? catawbiense, 191

- $\times$ nudiflorum, 176

- $\times$ occidentale, 181

- $\times$ speciosum, 176

- $X$ viscosum, 182

- Calleryi, 45

- calycinum, 63

- canadense, 120

- - albiflorum, 122

- - album, 122

- - viridifolium, 122

- $\times$ japonicum, 103, 185

- $\times$ luteum, 185

- candidum, 146

- canescens, 143

- canescens, 139

- candidum, 146

- - subglabrum, 145

- carneum elegantissimum, 193

- Cartoni, 189

- Cartonianum, 189

- caryophyllum, 52

- Comte de Kerchove, 194

- coreanum, 65

- crispiflorum, 27

- Crouxii, 194

- - plenum, 195

- Danielsianum, 23

- decandrum, 84

- Deception, 192

- decumbens, 23

- dianthiflor um, 76

- dilatatum, 83, 86

- - decandrum, 84

- typicum, 87

- discolor $\times$ occidentale, 192

- Eeckhoutei, 187

- elegantissimum, 191

- enneandrum, 190

- eximium, 192

- Farrerae, 79

- Farrerae, 81

- - leucotrichum, 81

- mediocre, 81

- typicum, 80

- Weyrichii, 81

- flammeum, 132

- flavum, 103

- - ardens, 178

- coronarium, 103, 178

- macranthum, 105

- Seymourii, 185

- versicolor, 177

- fragrans, 190
Rhododendron fragrans, 190, 191

- Fraseri, 103, 185

- gandavense, 178

plenum, 179

$x$ ? catawbiense, 192

- $\times$ Kosterianum, 183

- $\times$ molle, 183

- $\times$ occidentale, 180

- gemmiferum, 189

- glaucum, 161

- gnaphalocarpum, 81

- Gowerianum, 189

- hallaisanense, 65

- hangnoense, 23

- hispidum, 163

- hybridum, 189

- hybridum enneandrum, 190

- - glaucum, 189

- indicum, 22

- indicum, 45, 59

- - amoenam Buergeri, 32

- - amoenum genuinum, 32

- - amoenum japonicum, 33

- amoenum normale, 32

- - balsaminaeflorum, 26

- brachytrichum, 23

- - Buergeri, 32

- - crispiflorum, 27

- - eriocarpum, 49

- exquisitum, 26

- - formosanum, 45

- Hakatajiro, 26

- - hakatashiro, 25

- - Hexe, 44

- - incarnatum, 73

- - ignescens, 45

- - japonicum, 33

- Kaempferi, 38

- Kaempferi subalpina, 32

- - kinnozai, 26

- Kirishima, 29

- Iacioiatum, 27

- laciniatum, 27

- - lateritium. 23

- - macranthum, 23

- - macranthum genuinum, 23

- - macrostemon, 31

- Matsushima, 26

- - mikawanum, 43

- - obtusum, 29

- - obtusum album, 31

- - phoeniceum, 61

- - polypetalum, 27, 105

- - polypetalum, 27

- - pulchrum, 62

- - puniceum, 45

- - purpureum, 61

- Rollisoni, 26

- - rosiflorum, 26 
Rhododendron indicum sinensis, 59

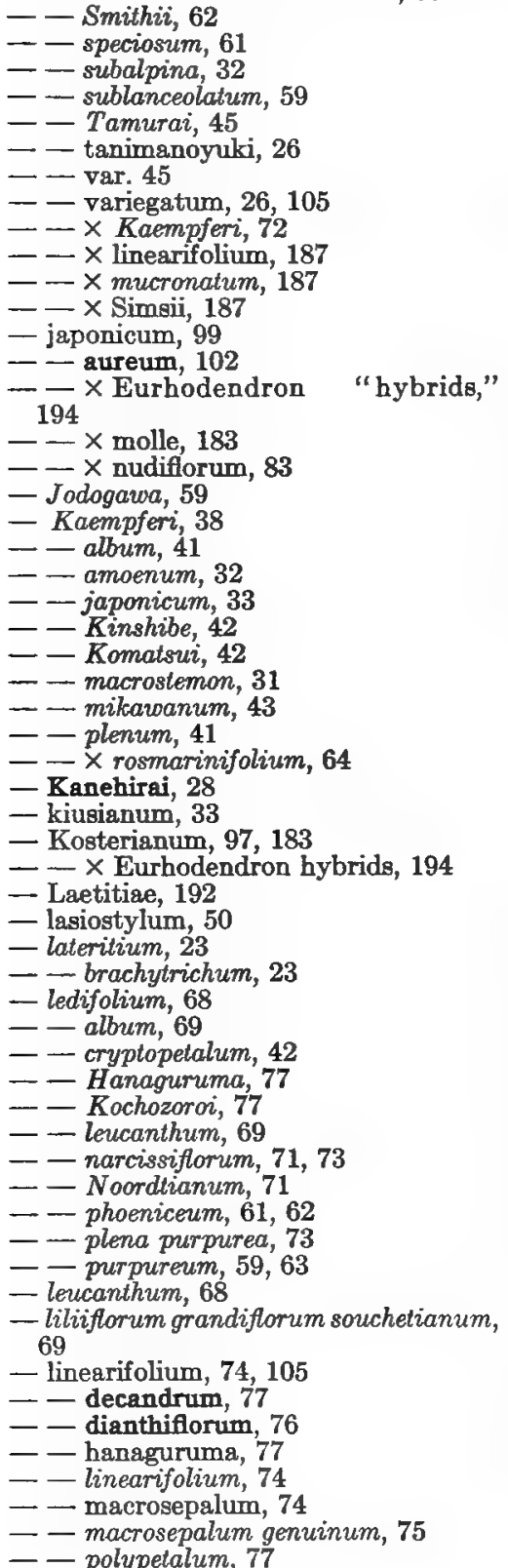

Rhododendron linearifolium rhodoroides, 77

- liukinense, 59

- longiperulatum, 67

- Loureiriana, 105

- luteum, 103

- luteum, 128

- - flammerim, 131

- - macranthum, 105

- $\times$ nudiflorum, 177

- $X$ ponticum, 192

- $X$ speciosum, 178

$-\ldots$ viscosum, 178

- macranthum, 23

- - albiflorum Souchetianum, 68

- - polypetalum, 105

- - semperflorens, 105

- macrosepalum, 74

- - A maga-shita, 78

- - Hanagumema, 77

- - linearifolium, 74

- Osuyo, 78

- - rhodoroides, 77

- - Suruga-momyo, 78

- macrostemon, 31

- Mariae, 58

- Mariesii, 80

- Matsumurai, 64

- Maxwellii, 64

- microphyton, 57

- mixtum, 98, 183

- molle, 95

- molle, 97, 99

- - glabrior, 99

- $\times$ arboreum, 193

- $\times$ (maximum $\times$ ponticum), 193

- $\times$ occidentale, 98,180

$-\ldots$ sinense, 97

- $-\times$ speciosum, 181

$-\ldots$ viscosum, 182

- Morterii, 176

- carnea, 176

- Mortieri, 176

$--\times$ luteum, 178

- $X$ viscosum, 178

- mucronatum, 68

- - amethystinum, 73

- Mattapan, 71

- - narcissiflorum, 71

- - Noordtianum, 71

- - plenum, 73

- - ripense, 72

- - sekidera, 72

- $\times$ scabrum, 187

- Nakaharai, 54

- linearifolium, 105

- narcissiflorum, 71

- nipponicum, 93, 119

- nilidum, 162

- Norbiton hybrids, 98, 193 
Rhododendron norbitonense, 193

- - aureum, 193

- - broughtonianum, 194

- nudiflorum, 134

- nudiflorum, 139, 143

- - albo-plenum, 138

- - album, 137

- - blandum, 198

- - carneum, 137

- carolinianum, 198

- Cartoni, 189

- - coccineum, 132

- - corymbosum, 198

- crispum, 198

- cumulatum, 198

- - discolor, 198

- eximium, 192

- - fastigiatum, 198

- - floridum, 198

- - glandiferum, 138

- - globosum, 199

- - glomeratum, 199

- - Govenianum, 189

- - incanum, 199

- - incarnatum, 199

- luteum, 146

- - mirabile, 199

- montanum, 199

- - pallidum, 199

- paludosum, 199

- - papilionaceum, 199

- - partitum, 199

- - parviflorum, 199

- - polyandrum, 200

- - proliferum, 200

- - pumilum, 200

- - purpurascens, 200

- - purpureo-plenum, 138

- - purpureum, 200

- - roseum, 139

- - ruberrimum, 200

- - rubescens, 200

- rubicundum, 200

- - rubro-plenum, 138

- - rubrum, 138

- - rufum, 200

- - rutilans, 200

- - scintillans, 178

- - semiduplex, 138, 200

- - stamineum, 200

- stellatum, 200

- - tricolor, 176

- - variabilis, 201

- - variegatum, 201

- - versicolor, 201

- violaceum, 201

- $\times$ catawbiense, 189

- $\times$ (catawbiense $\times$ ponticum $), 189$

- $\times$ ponticum, 188

- obtusum, 29
Rhododendron obtusum, 33

- - albiflorum, 41

_- album, 31

- - amoenum, 32

- - amoenum, 32

- - cryptopetalum, 42

- Honkirishima, 29

- - japonicum, 33

- - Kaempferi, 38

- Komatsui, 42

- - mikawanum, 43

- monstrosum, 42

multicolor, 41

- macrostemon, 31 plenum, 41

- oblongifolium, 150

- occidentale, 125

- - sonomense, 127

- $\times$ (arborescens $\times$ japonicum), 180

$--\times$ discolor, 192

- $\times$ molle $\times$ "Ghent Azaleas," 98, 183

-1 - $\times$ sinense, 98

odoratum, 190

- Oldhamii, 66

- glandulosum, 67

- Oomurasaki, 63

- ornatum, 178

- - incarnatum, 178

- - luteum, 178

- - roseum, 178

- speciosum, 178

- Osakazuki, 63

- pallidum, 191

- pentaphyllum, 92

- nikoense, 92

- phoeniceum, 61

- phoeniceum, 64

- - calycinum, 63

- Alore pleno, 73

- Maxwellii, 64

- - semiduplex, 62

- - Smithii, 62

- - splendens, 63

— - splendens, 63, 196

- - tebotan, 64

- ponticum, 103

- - azaleoides, 188

- - deciduum, 188

- - odoratum, 190

- - subdeciduru, 188

- Torloniana, 191

- poukhanense, 43, 65

- - acutifolium, 43

- - obtusifolium, 43

- - plenum, 64

- - yodogawa, 64

- prinophyllum, 139

- prunifolium, 169

- pulchrum, 62 


\section{8}

Rhododendron puniceum, 61

- purpureum, 43

- quinquefolium, 87

- - roseum, 92

- ramentaceum, 31

- reticulatum, 83

- - albiflorum, 86

- - pentandrum, 86

- Rhodora, 120

- - albiflora, 122

- rhombicum, 81,83

- - albiflorum, 86

- ripense, 72

- roseum, 138

- roseum odoratum, 191

- rosmarinifolium, 69

- - album, 69

- Fujimanyo, 73

- - narcissiflorum, 72

- Oriukiu, 71

- - purpureum, 63

- Sekidera, 72

- Shiromanyo, 72 speciosum, 63

- rubropilosum, 52

- Sanderi, 43, 187

- scabrum, 59

- scabrum, 43

- - angustifolium, 38 coccineum, 61

- Kaempferi, 38

- - latifolium, 38

- - purpureum, 43

- - tubiflorum, 38

- Schlippenbachii, 88

- Seniavinii, 57

- Sekidera, 72

- serpyllifolium, 53

- serpyllifolium, 54

- - albiflorum, 54

- serrulatum, 153

- - georgianum, 156

- - molliculum, 155

- Seymouri, 185

- shikokianum, 82

- shojoense, 81

- Sieboldii, 38

- - ellipticum, 60

- minor, 29

- - serrulatum, 23

- Simsii, 45

- - Bealii, 49

- - eriocarpum, 49

- - vittatum, 48

- $\times R$. obtusum, 43, 187

- sinense, 95, 97, 99, 102

- - flammerm, 95

- - flavescens, 95, 102

— $\times$ Eurhodendron, 98, 193

$-1 \times$ molle, 97

\section{INDEX}

Rhododendron Smithii aureum, 98

- Smithii aureum, 193

- sonomense, 127

- speciosum, 131

- speciosum, 131

- - acutifolium, 201

- - aurantium, 131

- - cilialum, 201

- - crispum, 201

- cucullatum, 201

- major, 132

- - obliquum, 201

- - prunifolium, 201

- - revolutum, 201

- - tortuifolium, 201

- - tortulifolium, 201

- - undulatum, 202

- $\times$ arboreum, 192

- $\times$ molle, 181

- sublanceolatum, 59

- sublateritium, 59

- subsessile, 51

- Tebotan, 64

- Thunbergii, 29

- Tolerianum, 191

- tosaense, 52

- tricolor, 176

- trinerve, 55

- Tschonoskii, 55

- - pentanerum, 55

- - tetramerum, 55

- - trinerve, 55

- - typicum, 55

- Vaseyi, 122

- - album, 123

- venustum, 135, 157

- viscosepalum, 182

- Daviesii, 182

- viscosum, 157

- viscosum, 153

- - aemulans, 165

- - coerulescens, 165

- - crispum, 202

- - dealbatum, 202

- - fissum, 166

- - glaucum, 160

- - hispidum, 163

- montanum, 164

- - nitidum, 162

- - ornatum, 178

- - penicillatum, 202

- - pubescens, 161

- rhodanthum, 160

- - roseum, 161

- - rubescens, 161

- - rubescens, 161

- - tomentosum, 162

- - variegatum, 202

$-\ldots \times$ ? catawbiense, 190

$-\ldots$ maximum, 189 
INDEX

Rhododendronviscosum $\times$ ponticum, 190 - vittatum, 49

- Bealii, 49

- punctata, 49

- Wadanum, 84

-Weyrichii, 82

- Weyrichii, 81,89

- Williamsii, 194
Rhododendron yedoense, 64 - - poukhanense, 65

- Yodogawa, 64

Rhodora, L., 119

- canadensis, 120

Theis, 124

Tsutsutsi, 22 






